\title{
Birds of the Kilbuck and Ahklun Mountain Region, Alaska
}

By

Margaret R. Petersen

Douglas N. Weir

Matthew II. Dick

N O R T H

AMERICAN

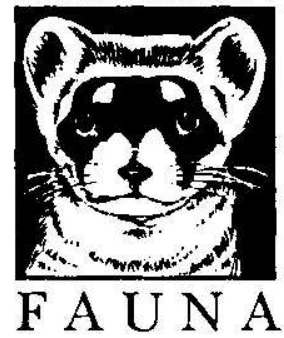

UNTTED STATES DEPARTMENT OF THE INTERIOR FISH AND WILDLIFE SERVICE North American Fauna 76

December 1991 



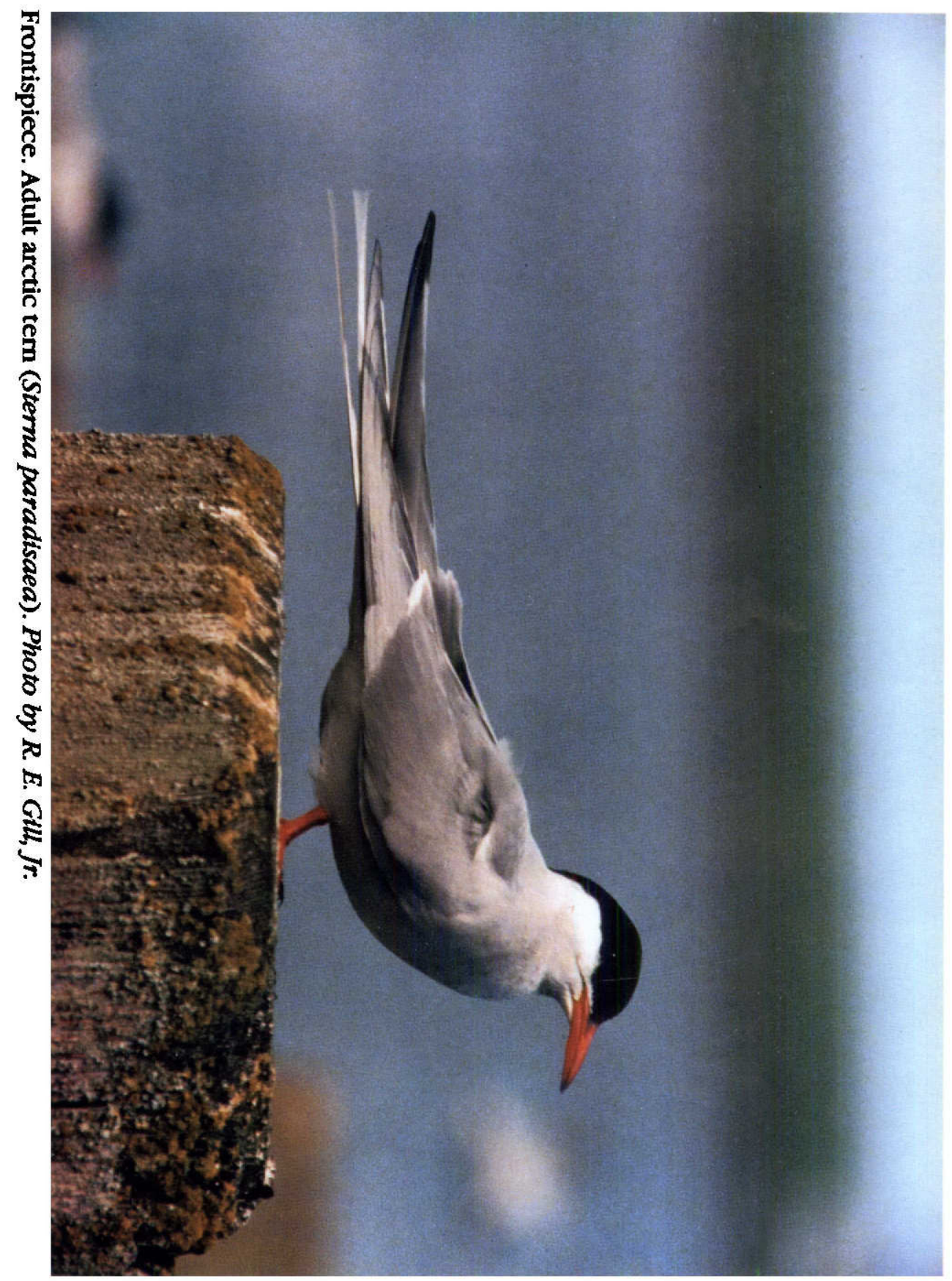





\section{Contents}

Page

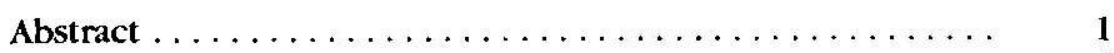

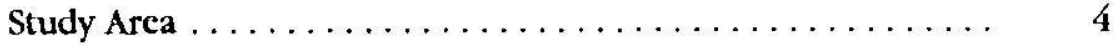

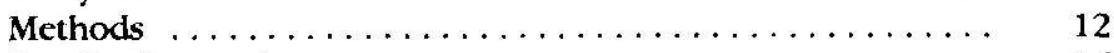

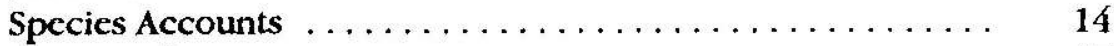

Annotated Species Accounts $\ldots \ldots \ldots \ldots \ldots \ldots \ldots \ldots, 17$

Discussion .............................. 129

Acknowledgments $\ldots \ldots \ldots \ldots \ldots \ldots \ldots \ldots \ldots \ldots \ldots, 152$

References ........................ 153

Appendix. Unpublished Reports on Birds in the Study

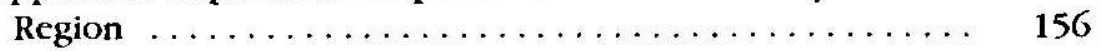




\title{
Birds of the Kilbuck and Ahklun Mountain Region, Alaska
}

\author{
by \\ Margaret R. Petersen \\ U.S. Fish and Wildlife Service \\ Alaska Fish and Wildlife Research Center \\ 1011 East Tudor Road \\ Anchorage, Alaska 99503 \\ Douglas N. Weir \\ c/o Scottish Ornithologists' Club \\ 21 Regent Terrace \\ Edinburgh, Scotland EH7 5BT \\ Matthew H. Dick \\ Department of Biology \\ Yale University \\ Box 6666 \\ New Haven, Connecticut 06511
}

\begin{abstract}
Between 1952 and 1988, we studied the abundance, distribution, occurrence, and habitats used by birds in the northwest portion of Bristol Bay and the adjacent Kilbuck and Ahklun mountains. In the 809 days we were present, we conducted 53 studies or surveys of birds in the region. We gathered information on 185 species, of which $65 \%$ (121) nested, $10 \%$ (19) probably nested, and $11 \%$ (21) were permanent residents in the region. Most breeding or probably breeding forms were of North American $(58 \% ; 81)$ or Beringian (24\%; 33) affinity, while the remainder of the species were of Panboreal $(17 \% ; 24)$ and Old World $(1 \% ; 2)$ affinity. Similarty, most of the $\mathbf{4 4}$ migrants and visitants were of North American $(41 \% ; 18)$ affinity, while the remainder were of Beringian $(32 \% ; 14)$ and Panboreal $(27 \% ; 12)$ affinity. Of the 140 species that nested or probably nested, $53 \%$ (73) were abundant to fairly common, $29 \%$ (40) were
\end{abstract}


uncommon to very rare, and $20 \%$ ( 27 ) were localized. Shrub thicket, dwarf shrub mat, coniferous forest, deciduous forest, mixed deciduous-coniferous forest, and fluviatile water and shoreline habitats supported the greatest diversity of species breeding and suspected of breeding. The highest concentrations of birds occurred in the estuaries of Nanvak, Chagvan, and Goodnews bays during spring and fall migrations and on the coastal and island cliffs during the breeding season.

The information presented here provides the basis for range extensions of several species. Our records further clarify the known or probable Alaska breeding ranges of 11 species (fork-tailed storm-petrel, Oceanodroma furcata; double-crested cormorant, Phalacrocorax auritus; red-faced cormorant, Phalacrocorax urile; brant, Branta bernicla; king eider, Somateria spectabilis; white-tailed ptarmigan, Lagopus leucurus; black-bellied plover, Pluvialis squatarola; Pacific golden-plover, Pluvialis fulva; lesser yellowlegs, Tringa flavtpes; Say's phoebe, Sayornis saya; and Bohemian waxwing, Bombycilla garrulus). We also provide further information on distributions or documentation of unusual occurrences for nine taxa (frigatebird, Fregata spp.; Baikal teal, Anas formosa; American kestrel, Falco sparverius; Terek sandpiper, Xenus cinereus; bristle-thighed curlew, Numenius tahitiensis; slaty-backed gull, Larus schistisagus; rufous hummingbird, Selasphorus rufus; song sparrow, Melospiza melodia; and red-winged blackbird, Agelaius phoeniceus). We provide quantitative data on the coastal migration of 11 species along Bristol Bay (red-throated loon, Gavia stellata; Pacific loon, Gavia pacifica; pelagic cormorant, Phalacrocorax pelagicus; emperor goosc, Chen canagica; brant; Steller's eider, Polysticta stelleri; common eider, Somateria mollissima; king eider; black scoter, Melanitta nigra; white-winged scoter, Melanitta fusca; and surf scoter, Melanitta perspicillata). We document changes in nesting densities, differences in numbers, or habitat variations of 32 species in response to human activities (e.g., semipalmated plover, Charadrius semipalmatus; arctic tem, Sterna paradisaea; tree swallow, Tachycineta bicolor, varied thrush, Ixoreus naevius; yellow-rumped warbler, Dendroica coronata; and American tree sparrow, Spizella arborea). We report the changes in a major colony of Aleutian terns (Sterna aleutica) at irregular intervals over 50 years.

Key words: Birds, western Alaska, distribution, status, migration, nesting habitat, zoogeography.

The Kilbuck and Ahklun mountains form the southeastern cdge of the Yukon-Kuskokwim River Delta and separate that flat, wet lowland region from the mountainous and wooded Bristol Bay region, which is to the south and east. The two mountain ranges are $30-130 \mathrm{~km}$ wide and extend $300 \mathrm{~km}$ from the coast at Cape Newenham to the north side of Mount Hamilton. The region contains a wide variety of geologic and topographic features, including mountains of varied relief $(600-1,500 \mathrm{~m}$ above sea level [asl]), rivers often flowing out of or through large upland lakes, wide and narrow river valleys, a small glacier, sea cliffs, large estuaries, and rocky offshore islands. This ecologically complex area is a 
transition or barrier between the very different ecoregions of the YukonKuskokwim River Delta and Bristol Bay.

The avifauna of this area has received little attention. Early studies in southwestern Alaska did not extend much beyond the Alaska Peninsula (Chapman 1904; Osgood 1904) and the eastern end of Bristol Bay (Hurley 1931-32), or they were restricted to the Yukon-Kuskokwim River Delta (Dice 1920a, 1920b; Conover 1926; Brandt 1943; Walkinshaw 1948a, 1948b, 1949; Walkinshaw and Stophlet 1949; Cady et al. 1955; Williamson 1957). D. Bernard Bull (in Friedmann 1933, 1934, 1936; Bent 1938) collected and observed birds near Goodnews Bay in the 1930's. Subsequent studies and surveys conducted by personnel of the U.S. Fish and Wildlife Service and the Alaska Department of Fish and Game extended into this area, but these were concentrated on coastal locations. Information was generally restricted to estimates of numbers of migrants using estuaries and of breeding seabirds (Arneson 1977; Sowls et al. 1978). Recently, personnel of the U.S. Fish and Wildlife Service, U.S. Bureau of Land Management, Alaska Department of Fish and Game, and others have made aerial surveys and float trips down some of the rivers during which they listed birds seen. Here, we present a detailed assessment of the relative abundance, seasonal occurrence, distribution, and habitat use of birds in the Kilbuck and Ahklun mountain region. 


\section{Study Area}

Our $21,000 \mathrm{~km}^{2}$ study area includes the mountainous region that forms the spine terminating in the peninsula that separates Kuskokwim Bay and Bristol Bay, and the adjoining lowlands and coastal waters. This area comprises portions of the three biogeographic regions delineated by Kessel and Gibson (1978) as southwestern, western, and central. The eastern boundary of our study area followed the eastern foothills of the Togiak River valley from Kulukak Bay northwards to Togiak Lake and other source lakes (Fig. 1). It then followed the east-west divide of the Kilbuck Mountains to the Salmon River and down the Salmon River to its confluence with the Aniak River. The northern boundary from the Aniak River west to Ophir Creek was an imaginary line about $75 \mathrm{~m}$ asl along the indefinite limit of the foothills above the lower Kuskokwim plain. The westem boundary ran south from Ophir Creek along the sharply defined outer limit of the foothills to the coast at Jacksmith Bay. From there, the boundary ran southwest to Cape Newenham and then east to just west of Kulukak Bay. The study area included Jacksmith Bay, Carter Bay, Goodnews Bay, Chagvan Bay, Security Cove, Nanvak Bay, Togiak Bay, all waters within $5 \mathrm{~km}$ of the coast, and all nearby islands, including Hagemeister Island, Summit Island, and the Walrus Islands.

The area is geologically complex (Hoare and Coonrad 1959, 1961; Selkregg 1976). In general, it is underlain by mesozoic sedimentary and metamorphic rocks, with some areas of volcanic and intrusive rocks. Nearly all of the area was glaciated in the Pleistocene, except perhaps the lower valleys of the rivers flowing from the Kilbuck Mountains (Hartmann and Johnson 1977). Some of the area is underlain by continual permafrost (Hartmann and Johnson 1977).

The climate of the study area is transitional and continental in the northern portion, transitional over the remaining inland areas, and maritime at capes and offshore islands (Hartmann and Johnson 1977). Temperatures $175 \mathrm{~km}$ inland at Nyac range from $-45^{\circ} \mathrm{C}$ in winter (mean high and low, $-11^{\circ} \mathrm{C}$ and $-20^{\circ} \mathrm{C}$, respectively) to $30^{\circ} \mathrm{C}$ in summer (mean high and low, $19^{\circ} \mathrm{C}$ and $3^{\circ} \mathrm{C}$, respectively; Hartmann and Johnson 1977). On the coast, temperatures range from $-33^{\circ} \mathrm{C}$ in winter (mean high and low, $-7^{\circ} \mathrm{C}$ and $-16^{\circ} \mathrm{C}$ ) to $24^{\circ} \mathrm{C}$ in summer (mean high and low of $15^{\circ} \mathrm{C}$ and $7^{\circ} \mathrm{C}$; Brower et al. 1988). The entire area receives about $100 \mathrm{~cm}$ of precipitation each year, including about $200 \mathrm{~cm}$ of snow. Inland, ice forms on rivers beginning in October, and rivers are usually ice-free in early May. Along the west coast, fast or close ice forms beginning in October and may last until May, and ice may extend to several kilometers south of the study area in some years (Brower et al. 1988). 


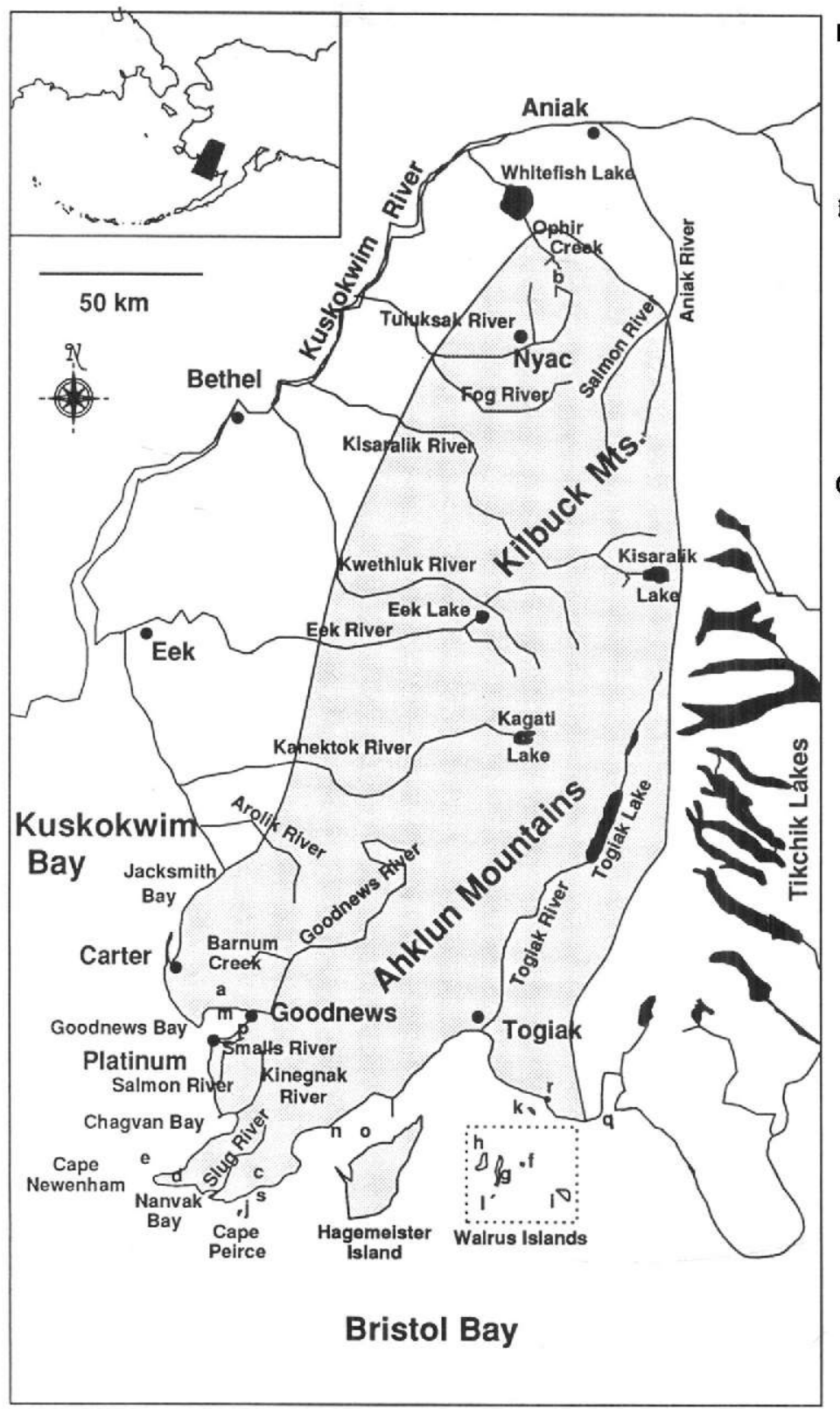

Mountains

a Beluga Peak

b Mount Hamliton

c Siug Mountain

d Tokomarlk Mountain

Islands

- Blrd Rock

f Black Rock

g Crooked Island

h Hlgh lsland

I Round Island

I Shaiak Island

k Summit Island

I Twin Islands

\section{Other locations}

$\mathrm{m}$ Big and Little Beluga

n Estus Point

- Hagemeister Strait

p IInak Lakes

q Kulukak Bay

I Nunavachak Lake

S Pyrate Point

Fig. 1. Study area and locations of places mentioned in the text.

Viereck and Little (1972) show much of the study area covered by moist tundra, alpine tundra, and shrub thickets. Drainages of the eight major rivers in the inland area are covered primarily with moist tundra and alpine tundra (Fig. 2), while trees (mainly white spruce, Picea glauca; 


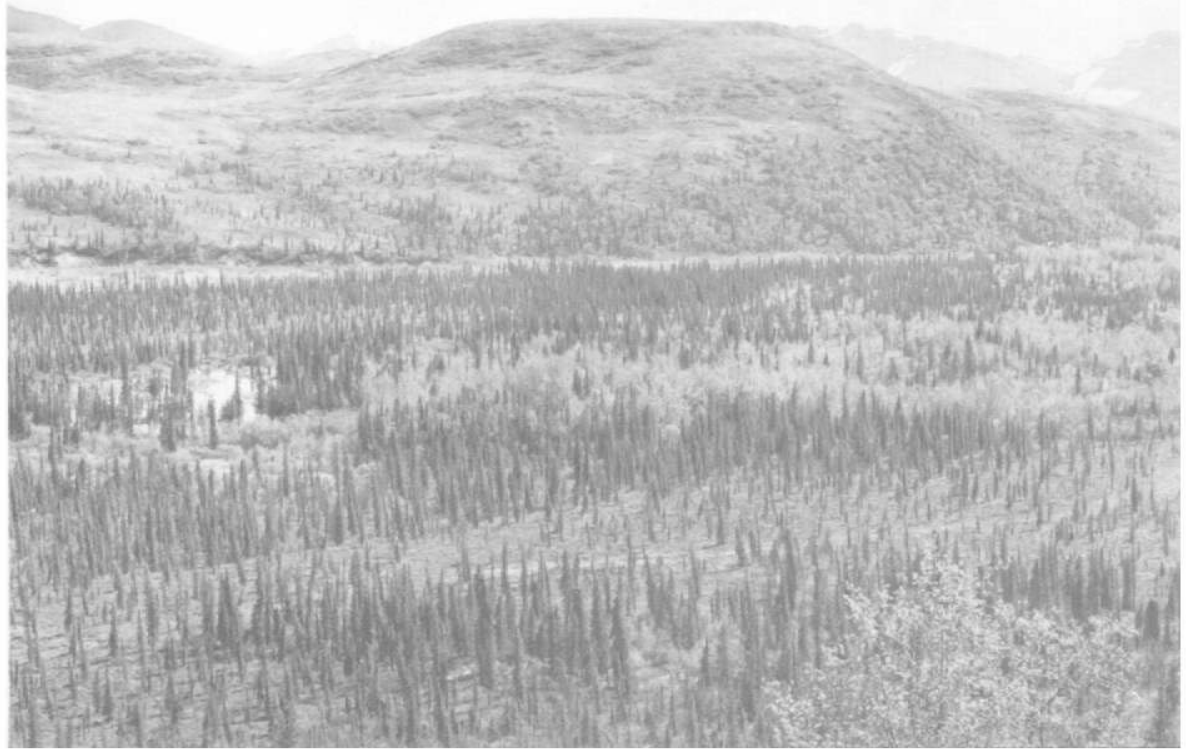

Fig. 2. The Togiak River and drainage, August 1973. Photo by M. H. Dick.

black spruce, Picea mariana; paper birch, Betula papyrifera; and balsam poplar, Populus balsamifera) are found on the main valley floors and lower hills and slopes (Fig. 3). Broken tracts of alder (Alnus spp.) and willow (Salix spp.) are found throughout the area beyond timberline (Fig. 4). Tamarack (Larix laricina), black spruce, aspen (Populus tremu-

Fig. 3. Vegetation typical of main valley floors and lower hills and slopes; the Tuluksak River at lower State Lake and hills to the west, earty June 1974. Photo by D. N. Wetr. 


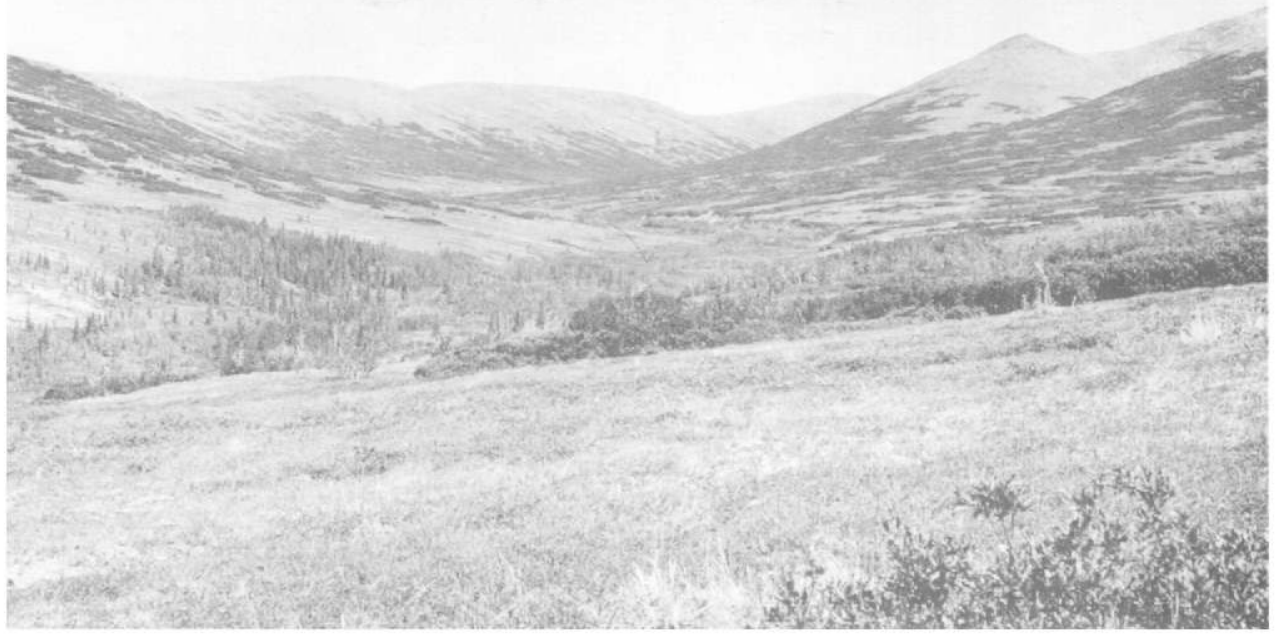

Fig. 4. Broken tracts of alder and willow as found throughout areas above timberline; upper Tuluksak River area, June 1974. Photo by D. N. Weir.

loides), and resin birch (Betula glandulosa) form the understory of black spruce woodlands. Black spruce woodlands are largely confined to the extreme northeastern interior of the study area, although some persist southward near the western foothills. Forests are often low and open (Fig. 5), and growth is slow; white spruce rarely exceed heights of $18 \mathrm{~m}$,

Fig. 5. Low, open forest typical of main valley floors; view up Slate Cheek, Tuluksak River, early June 1977. Photo by D. N. Weir. 
and growth to $15 \mathrm{~m}$ may require more than 200 years. West of the Kilbuck Mountains, riparian woodlands persist in narrow bands across the tundra of the Kuskokwim River plain to the lower Kuskokwim River woodland. Along the western face of the Ahklun Mountains, woodlands are lower, more open, and generally more restricted to sites sheltered from the coastal plain.

Much of the coast and the islands consist of steep, rocky cliffs, rocky promontories, and rocky shores (Fig. 6), with estuaries and freshwater wetland habitats occurring at the mouths of most major rivers (Fig. 7 ). The exposed, windswept ridges and hilltops of the capes and islands are characterized by numerous rocks, bare soil, fell-field, and dry dwarf shrub mat habitat (Fig. 8). In more protected areas on the capes and in the mountains, grass meadows and low and medium shrub thickets occur, although dwarf shrub mat habitat still predominates. Lowlands near estuaries (Fig. 9) are generally wet meadows, brackish and freshwater ponds, dwarf shrub meadows, and saltgrass meadows.

Estuarine bays are generally shallow and contain large beds of eelgrass (Zostera marina). At low tide the bays are drained by deeper channels, and considerable areas of mud- and sandflats are exposed. Scattered around the bays are salt marshes drained by tidal sloughs. All of these estuarine areas provide important feeding and gathering spots for waterfowl and shorebirds during migration. Each bay and Hagemeister Strait has one or more long, narrow sandy spits separating the bay from open water. These spits are generally a combination of bare ground

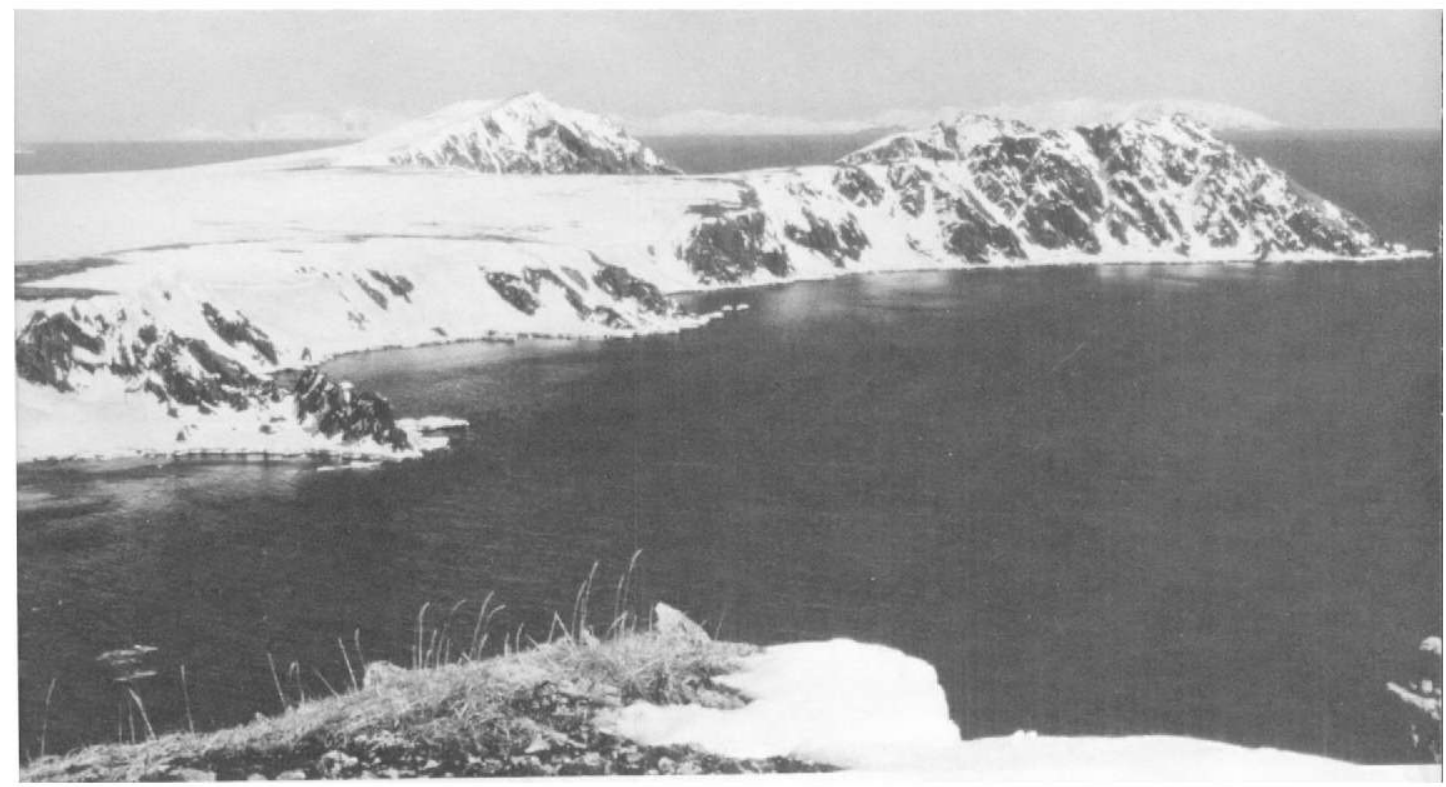

Fig. 6. Sea cliffs south from Cape Peirce with Hagemeister Island in the background, 30 April 1976. Photo by M. R. Petersen. 


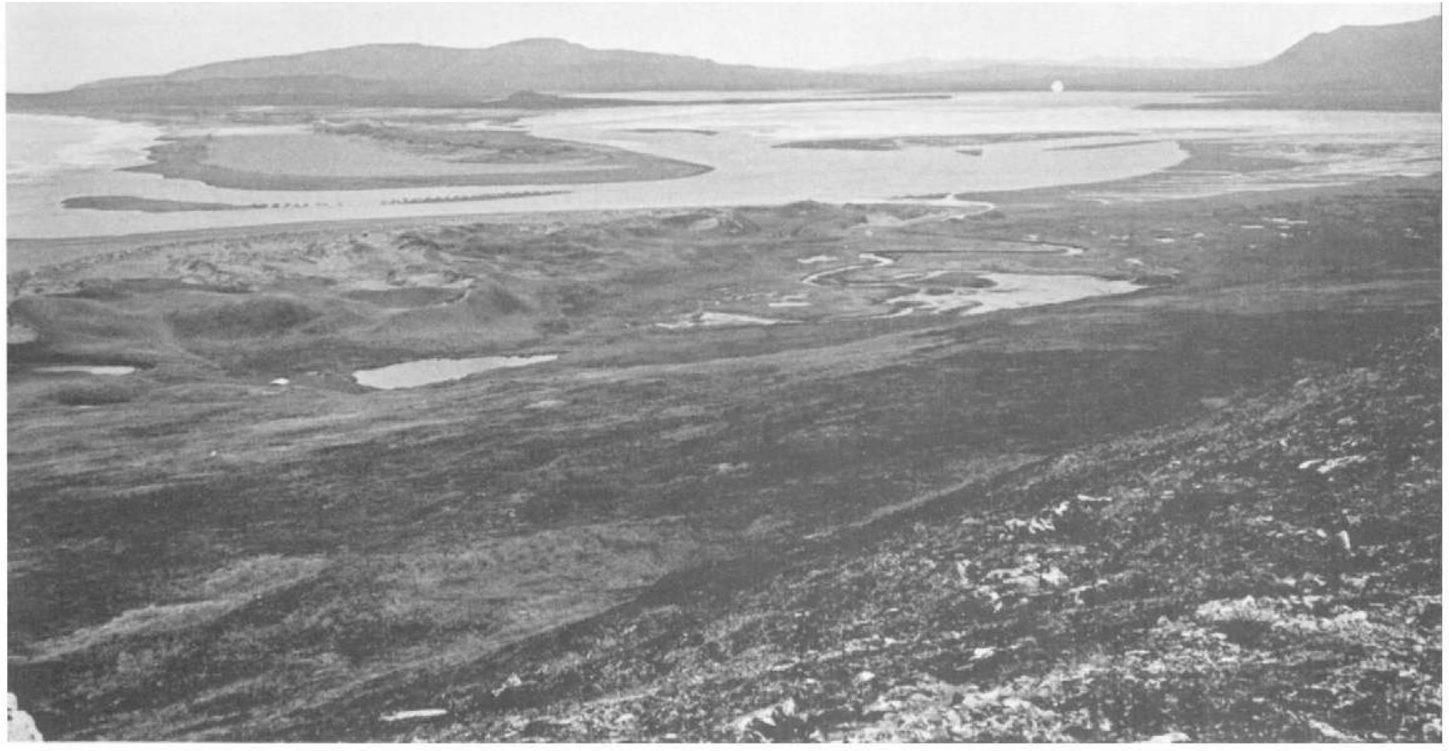

Fig. 7. Nanvak Bay at low tide and adjacent dunes and wetlands. Photo by $M$. H. Dick.

and vegetation composed of Elymus arenarius, Honckenya peploides, and Mertensia maritima, and dwarf shrub mat.

The intertidal zone along more exposed shores includes a varicty of substrate types, including sand, fine gravel, coarse gravel, cobble, boulder, and solid rock strand and cliff. The marine portion of the study area is underlain by the continental shelf and is fairly shallow. Along the

Fig. 8. Fellfield tundra atop Cape Peirce, 21 August 1976. Photo by M. R. Petersen. 
Fig. 9. Wet meadow adjacent to Nanvak Bay, 24July 1976. Photo by M. R. Petersen.

western portion, fast or close ice begins to form as early as October and may last until May; in some years, pack ice extends to several kilometers south of the study area (Brower et al. 1988). In summer, sea surface temperatures reach $11^{\circ} \mathrm{C}$.

Inland and on part of the west coast, placer mining has been widespread (Fig. 10), but only one camp, Nyac, on the Tuluksak River is now inhabited all year. Elsewhere, human settlements are mainly at the mouths of the largest rivers and include the villages of Carter, Goodnews, Platinum, and Togiak. The U.S. Air Force has a small station at Cape Newenham. Other mining camps are used in summer, as are some of the bays and larger rivers for subsistence hunting and fishing as well as recreation.

Most of the Kilbuck and Ahklun mountains are part of the Togiak and Yukon Delta national wildlife refuges. Many parcels of land have been selected for ownership by native villages and individuals. The offshore islands are part of either the Alaska Coastal National Wildlife Refuge or the Walrus Islands State Game Sanctuary. The Kisaralik River is a candidate for Wild and Scenic River status. The remaining land areas are under the jurisdiction of the Bureau of Land Management and the State of Alaska. However, ownership and control of much of the land has yet to be resolved. 


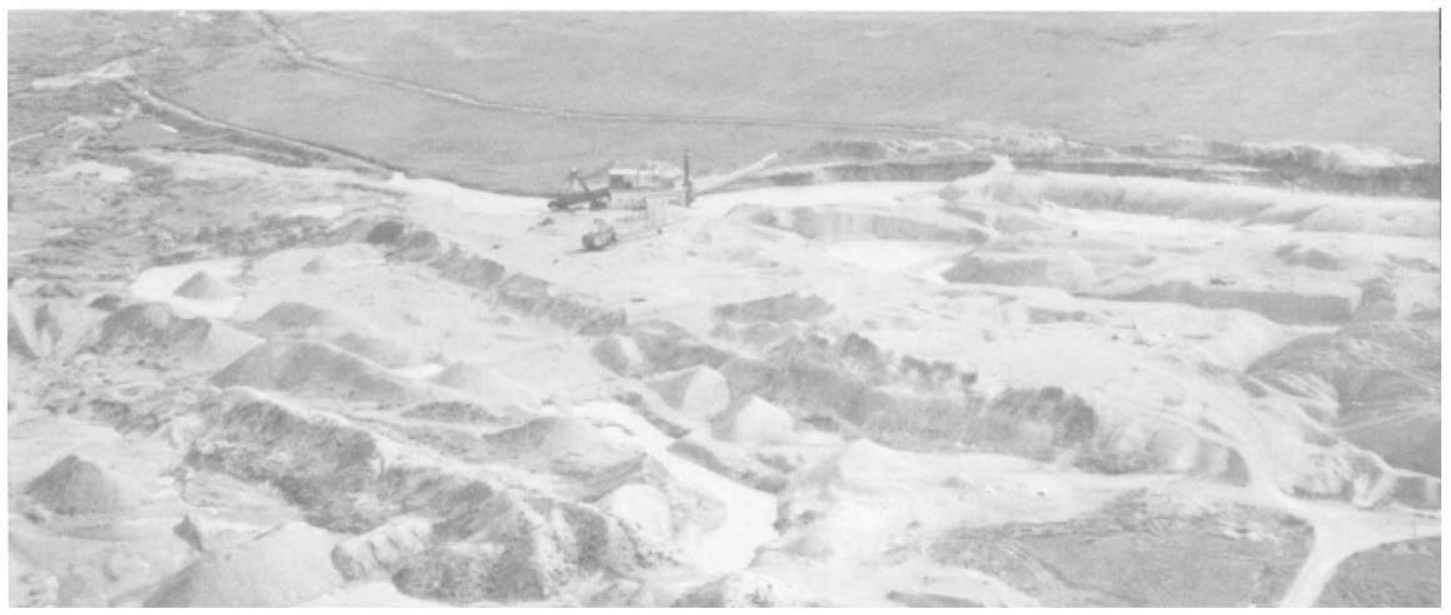

A

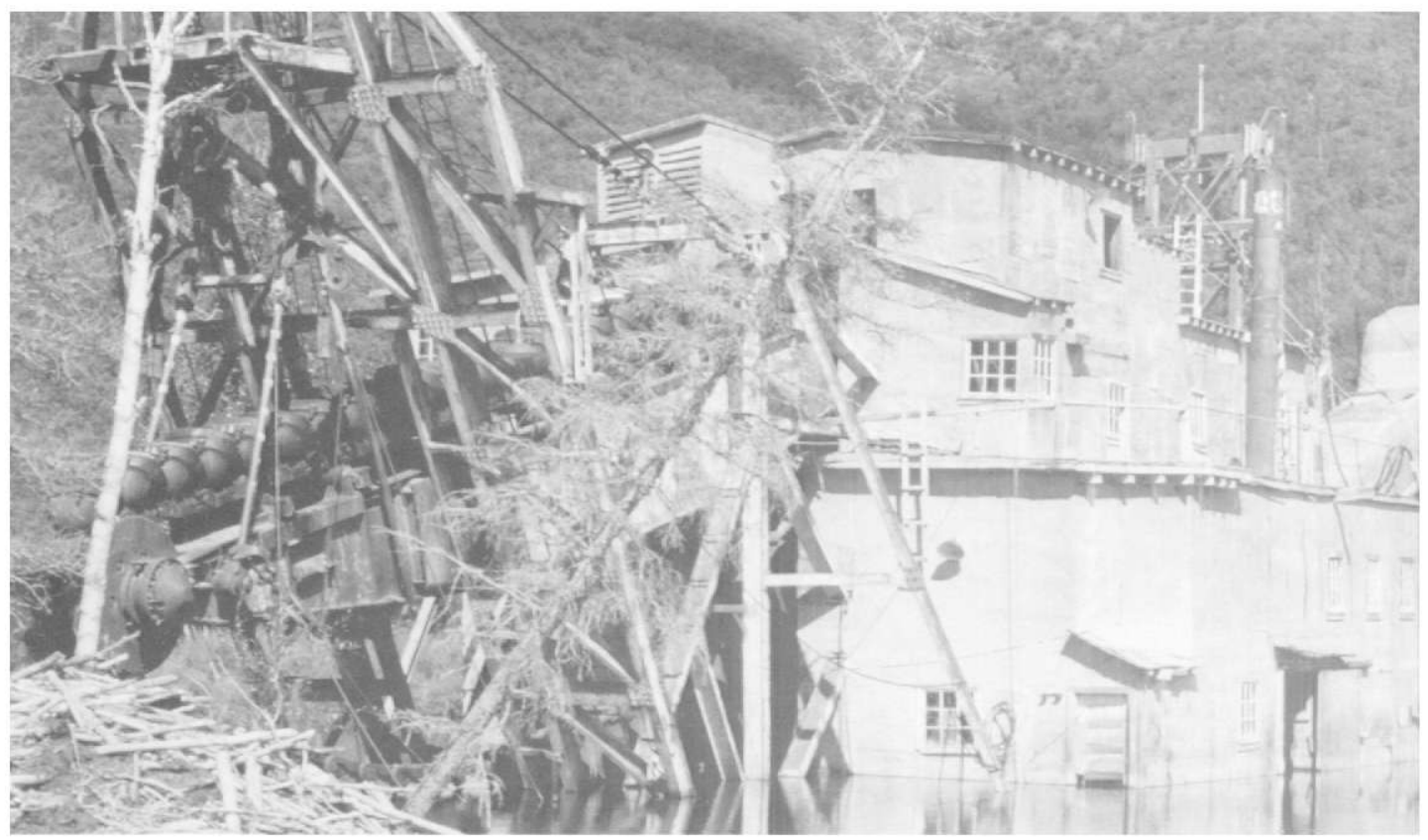

B

Fig. 10.A. Placer mining operation at Platinum, July 1977. Photo by M. R. Petersen. B. Abandoned gold dredge typical of those used as nesting sites by common goldeneyes, cliff swallows, Say's phoebes, rough-legged hawks, and other species. Photo by D. N. Weir. 


\section{Methods}

We were present on the study area for 809 days between 1952 and 1987 (Table 1). Our fieldwork occurred mostly during the 1970's and included most ecologically distinct areas. The foundations for this paper are data from D. N. Weir's (DNW) study of breeding birds on the Tuluksak River, with specific reference to the effects of surface mining, and M. H. Dick's (MHD) and M. R. Petersen's (MRP) studies of breeding seabirds and coastal migration of waterbirds at Cape Peirce and Nanvak Bay. Supplemental data are included from the published and unpublished reports of surveys of cliff-nesting raptors and other birds along the northern interior Kisaralik River (White and Boyce 1978; Weir 1982; Mindell 1983); rcconnaissances and notes by residents and visitors from 1933 to 1988 (MHD, DNW, and others); notes on birds at Kagati Lake and

Table 1. Studies and surveys conducted in the Kilbuck and Ahklun mountains and nearby islands.

\begin{tabular}{|c|c|c|c|c|}
\hline $\begin{array}{l}\text { General } \\
\text { location }\end{array}$ & $\begin{array}{c}\text { Type } \\
\text { of study }^{\mathbf{a}}\end{array}$ & $\begin{array}{l}\text { Total } \\
\text { days }\end{array}$ & $\begin{array}{l}\text { Range } \\
\text { of dates }\end{array}$ & Years \\
\hline Salmon River & $\mathrm{Gr}, \mathrm{Fl}, \mathrm{Ae}$ & 17 & 6 July - 24 Aug. & $1974,1977,1979,1986$ \\
\hline Tuluksak River & $\mathrm{Gr}, \mathrm{Ae}$ & 396 & 29 May - 9 Nov. & $\begin{array}{l}1952,1962,1974 \\
1976-81,1983 \\
1986-87\end{array}$ \\
\hline Fog River & $\mathrm{Ae}$ & 2 & 16,25 July & 1976,1978 \\
\hline Kisaralik River & $\mathrm{Gr}, \mathrm{Fl}, \mathrm{Ae}$ & 15 & 11 July - 15 Sept. & $1977-79$ \\
\hline $\begin{array}{l}\text { Kagati Lake and } \\
\text { Kanektok River }\end{array}$ & $\mathrm{Ae}$ & 1 & 13 July & 1962 \\
\hline Arolik River & $\mathrm{Ae}$ & 4 & 11 June- 16 Sept. & $1974,1977,1980$ \\
\hline $\begin{array}{l}\text { Goodnews and } \\
\text { Chagvan bays and } \\
\text { Kinegnak River }\end{array}$ & Gr & 28 & 11 June - 15 Sept. & $\begin{array}{l}1974,1977,1980,1986 \\
1988\end{array}$ \\
\hline Cape Newenham & $\mathrm{Gr}, \mathrm{Ae}$ & 8 & 19 May - 31 Aug. & 1973,1977 \\
\hline $\begin{array}{r}\text { Cape Peirce and } \\
\text { Nanvak Bay }\end{array}$ & $\mathrm{Gr}, \mathrm{Ae}$ & 334 & 27 Apr. -27 Sept. & $1969,1970,1973,1976$ \\
\hline Walrus Islands & Gr, Bo & 2 & $8-9$ July & 1962 \\
\hline $\begin{array}{l}\text { Togiak River and } \\
\text { and Togiak Lake }\end{array}$ & $\mathrm{Gr}, \mathrm{Fl}$ & 10 & 6 July -9 Aug. & 1962,1973 \\
\hline Coastal surveys & Ae & 2 & 21 Aug. -8 Sept. & 1976,1977 \\
\hline
\end{tabular}

${ }^{a} \mathrm{Gr}$ - ground survey, F1 - float trip, Ae - aerial survey, Bo - boat survey.

${ }^{b}$ Earliest to latest dates an observer was present. 
along the Kanektok River (DNW and others); float trips down the Salmon, Aniak, Eek, Kanektok, and Togiak rivers (DNW, MHD, and others); and observations of cliff-nesting raptors, waterfowl, and seabirds from boats and airplanes (MRP, DNW, and others). Unpublished reports cited in the text are listed in the appendix. We also drew on Gabrielson and Lincoln (1959) and Kessel and Gibson (1978). Petersen (1982), Weir (1982, 1988), Herter et al. (1989), and Weir and Hanson (1989) present detailed accounts of certain aspects of avian ecology of our study area.

All references to relative abundance, seasonal occurrence, distribution, and habitat use are from our studies unless otherwise stated. 


\section{Species Accounts}

We summarize records of 185 species of birds seen between 1952 and 1988. Eighteen (10\%) of these species were not observed by us and were neither photographed nor collected. Since few longterm studies have been conducted in the area and the region is largely uninhabited, we have included all observations of birds provided to us by trained observers. Many of these species are distinctive with little possibility of misidentification, and some are common in adjacent areas. With few exceptions, we believe that with additional studies in our area many species will prove to be more common and widespread than we report here.

Relative abundance and seasonal occurrence follow Salter et al. (1980), with modifications. Relative abundance is denoted as follows:

abundant (A): observed each year, preferred habitat(s) widespread; occurred throughout preferred habitat(s), during migration in consistently high numbers, or both.

common (C): same as abundant, but in moderate numbers.

fairly common (FC): same as abundant, but in low to variable numbers. uncommon (U): usually observed each year, but occurred in low numbers or in restricted habitats.

rare (R): not observed each year; observations sporadic; no more than

a few locality records in any year.

very rare (VR): fewer than five records during the study.

Seasonal occurrence is denoted as follows:

permanent resident (pr): individuals present all year.

summer resident (sr): present only seasonally, in summer; nests, eggs, or nonvolant young reported.

winter resident (wr): present only seasonally, in winter.

spring or fall migrant (spm, fm): present only during migration, or primarily during migration periods.

visitant (v): includes but is not limited to molting, nonbreeding, failed breeding, and postbreeding individuals, as well as individuals out of their normal range.

Indirect evidence of breeding was noted as sr? In these cases, "possible" and "probable" breeding are as defined by Sharrock (1976). possible breeding birds were those found in appropriate nesting habitat in summer but for which no indication of nesting was noted. Indications of probable breeding included singing males or breeding calls heard; territorial males or pairs; courtship or other displays indicative of nests or young; brood patches on females; or nest-building activities. 
Species thought to winter in the area have been indicated as wr? Spring migrant adults generally appear in April-May, whereas spring migration for subadults of some species may not occur until late May or June when breeding birds have begun nesting. Similarly, fall migration for some species (particularly shorebirds) may commence with the occurrence of subadults and failed breeders while adults are still raising young; thus, fall migration can occur as carly as June and as late as October. We refer to summer as the period after snowmelt when most species are nesting. Winter is the time from freeze-up to early break-up; this is generally from October to March and is characterized by extensive snow cover on land; ice formation on ponds, lakes, rivers, and lagoons; and persistent snow fall. We give dates of carlicst and latest observations for all but rare or very rare species. These dates may reflect when the species occurs but, in part, also reflect our own seasonal presence at locations.

Rates of migration were estimated from observations of birds passing the cliffs at Cape Peirce from late April until early September. Observations in 1976 were 2 -hour sessions conducted on alternate days similar to that described by Herter et al. (1989). In 1970 and 1973, observations were conducted when an increase in migrants was observed. Densities of passerines at Cape Peirce are estimated from a transect $(3.4 \mathrm{~km}$ long, $184 \mathrm{ha}$ ) crossing the peninsula from Nanvak Bay toward Ilagemeister Island and another ( $1.6 \mathrm{~km}$ long, $86 \mathrm{ha}$ ) following the western cliff edge. The number of birds, species, bchavior, and status of nests were determined along the cape transect at irregular intervals in 1973 (9 surveys) and weckly at each transect in 1976 (33 surveys). Birds at the Tuluksak River were surveyed in 1983 by the fixed-width strip census method in plots totaling 130 ha. Comparisons were made of densitics of passerines in 13 plots disturbed by mining activity to 13 plots in nearby undisturbed areas. When possible, data are presented as mean $\pm \mathrm{SE}$.

Specimens have been deposited with the University of Alaska Museum (UAM), Fairbanks; Yukon Delta National Wildlife Range, Bethel, Alaska (YDNWR); Department of Wildlife and Fisherics Biology Museum, University of California (WFB), Davis; British Muscum (Natural History) (BMNH), Trint; and Royal Museum of Scotland (RMS), Edinburgh. More complete specimen data can be obtained from the authors. Species documented by photographs are noted by photographer (e.g., nest, eggs; DNW photo).

Scientific names and taxonomic order of birds follow American Ornithologists' Union (1983) with exceptions as noted. Scientific names of mammals follow Banks et al. (1987) and of plants follow Hultén (1968). Zoogeographic affinities of birds are from Kessel (1989). Classification of habitats follows Kessel (1979). Place names are from USGS 
1:63360 topographic maps. There are two Salmon Rivers on our study area: The larger one, which flows into the Aniak River, is referred to as the Salmon River. The smaller river near Goodnews Bay is referred to as the Salmon River (Goodnews). There are several Round Islands in Alaska. The Round Island to which we refer to is the one in the Walrus Islands State Game Sanctuary. 


\section{Annotated Species Accounts}

Red-throated loon (Gavia stellata). Aspm, FCsr, Ufm (3 May25 September).

Red-throated loons ncsted throughout the study area and migrated along the coast. They were abundant spring migrants past Cape Pcirce from 3 to 26 May (peak migration rate of 50 birds per hour for $2.05 \mathrm{~h}$ on 6 May 1976), and birds were present, presumably migrating, after carly September in nearshore and inshore waters. We found them nesting near Nanvak Bay and the Togiak River and probably nesting near the Salmon River, at Kisaralik Lake, and Goodnews and Chagvan bays. Adults were seen in summer at the Kisaralik River (M. Brown et al., unpublished; B. J. McCaffery, personal communication), at the Kwethluk River (M. Brown et al., unpublished), and at the Eek River (R. Baxter, unpublished; $M$. Brown et al., unpublished). Adults, probably nesting, were secn near Kagati Lake (M. J. Fry, unpublished). On 3 July 1961 on a small pond near Nanvak Bay, J. G. King (unpublished) found a pair that may have ncsted. On 23 June 1976 on that same pond, we found a day-old chick (MRP photo) that fledged 7-8 wecks later. D. R. Herter and D. Lloyd (personal communication) found a pair that raised two chicks there in 1981. We also found two unfledged young on the Togiak River on 5 August 1973. P. D. Arneson and D. B. McDonald (personal communication) found two birds near Crooked Island in June and seven near Ilagemeister Island in July 1977.

Pacific loon (Gavia pacifica). Aspm, Rsr, Cfm (5 May-25 September).

Pacific loons nested in the Ahklun Mountains and were common to abundant migrants along the coast. Breeding-plumaged birds passed Cape Peirce at rates of up to 132 birds per hour (during 2 h on 20 May 1976) during spring migration. Birds were rarely seen in Nanvak Bay or on inshore waters along the cliff faces during spring migration. During late summer and fall, they were seen occasionally in Chagvan Bay July); we saw birds near Cape Peirce and in Nanvak Bay Junc-September) cach year, as did H. P. Brokaw, unpublished (26 and 29 June 1970, four and seven birds, respectively). Birds were found near Crooked Island in June-July and at I Jagemeister Island in July 1977 (P. D. Arneson and D. B. McDonald, personal communication). We saw an adult with one young in a pond near Jacksmith Bay on 9 September 1976. In inland areas, birds were found at the Kisaralik River on 16 June 1987 (B. J. McCaffery, 
personal communication) and 8-15 August 1985 (M. Brown et al., unpublished) and at the Kwethluk River on 25 July 1985 (M. Brown et al., unpublished). M. J. Fry (unpublished) found birds that may have nested at or near Kagati Lake, and White and Boyce (1978) found one bird on the Kanektok River.

\section{Common loon (Gavia immer). Uspm, Usr? (18 May-28 August).}

Common loons possibly nested in the Ahklun Mountains and migrated along the coast. At Cape Peirce we saw migrants in spring ( 13 birds during 18 May-1 June 1976) and occasionally in June-September in inshore waters during storms (six observations). During the nesting scason, P. D. Arneson and D. B. McDonald (personal communication) saw a common loon ncar Crooked Island on 22 June 1977, and we saw birds at Togiak Bay and river mouth in summer. In inland areas, Mindell (1983) found birds near Nyac; M. Brown et al. (unpublished) found birds at the Kisaralik River on 10-17 August 1985; we saw an adult on Togiak Lake on 3 August 1973; M. Brown et al. (unpublished) saw one bird on 17 June 1985 at the Eek River; M. J. Fry (unpublished) found brecding plumage birds in summer 1962 at Kagati Lake; White and Boyce (1978) saw a bird on the Kancktok River near Kagati Lake in June 1977.

\section{Yellow-billed loon (Gavia adamsii). VRv.}

One bird in breeding plumage flew over Cape Peirce on 3 September 1976. D. R. Herter et al. (personal communication) also saw one at Cape Peirce on 8 June 1984.

Horned grebe (Podiceps auritus). Rv.

Horned grebes were found in the Kilbuck Mountains, on the river system between the Kilbuck and Ahklun mountains, and along the coast. We found a horned grebe at the Tuluksak River in August 1952; B. J. McCaffery (personal communication) found a bird at the Kisaralik River on 17 June 1987; M. J. Fry (unpublished) found birds at Kagati Lake (7-9 August 1962) and the Kanektok River (20 August 1962). We observed several birds at Cape Peirce (10 observations, all adults) in 1973 during 17 May-10 June and 28 August-24 September and in 1976 during 13-28 May and on 27 August, (5 observations); a single grebe was seen at Summit Island on 11 July 1977 (P. D. Arneson and D. B. McDonald, personal communication).

Red-necked grebe (Podiceps grisegena). Uv (10 May-25 September).

Red-nccked grebes were found in the Ahklun and Kilbuck mountains and on the coast. At coastal locations grebes were at Cape Peirce in July 
1969 (one; J. L. Hout, unpublished), 26 Junc 1970 (one; H. P. Brokaw, unpublished), July-September 1970-76 (several); September 1971 (one; J. L. Hout, unpublished), 22 June 1981 (one; D. R. Herter and D. Lloyd, personal communication), and 12 July 1984 (one; D. R. Herter et al., personal communication). Grebes were also observed along the coast at Goodnews Bay (one on 15 September 1977), Crooked Island (one during 26 June-14 July 1977; R. D. Arneson and D. B. McDonald, personal communication), and Hagemister Island (three on 10 July 1977; P. D. Arneson and D. B. McDonald, personal communication). At Cape Pcirce, groups of one to four birds, mostly adults in alternate plumage or in prebasic molt, were found primarily in inshore waters. Inland, M. J. Fry (unpublished) saw a grebe at Kagati lake on 5 August 1962; M. Brown et al. (unpublished) found several (6-15) at the Kisaralik River on $15 \mathrm{Au}$ gust 1985 and $<5$ birds per day on 5 days between 17 and 23 June 1985 at the Eck River.

Northern fulmar (Fulmarus glacialis). VRv.

One bird was seen at Round Island on 15 July 1974 (T. J. Eley, unpublished). Fulmars were reported as fairly common in nearby offshore waters 13 July-20 August 1969 (Bartonek and Gibson 1972).

Short-tailed shearwater (Puffinus tenuirostris). VRv. Specimen: UAM2619.

Birds were seen near Round Island on 14-23 July 1974 (T. J. Eley, unpublished) and 27 June 1976 (R. MacIntosh, unpublished) and were recorded near Hagemeister Island in July 1946 (Gabrielson and Lincoln 1959). We collected a sick bird in Nanvak Bay on 16 August 1973. On Crooked Island, Arneson (1977) found 17 beached shearwater carcasses on his first visit to beaches, and an additional 6 carcasses were found between 21 June and 7 July 1977 . In nearby offshore waters, shearwaters are abundant in summer (Bartonek and Gibson 1972).

Fork-tailed storm-petrel (Oceanodroma furcata). Rst.

Fork-tailed storm-petrels were found nesting on Round Island in 1974 (T. J. Elcy, unpublished). Around 14-23 July, T. J. Eley (unpublished) observed eight birds flying near the island, heard birds calling during the day, found three birds in the remains of red fox (Vulpes vulpes) kills, found many burrows and smelled petrel odor in the burrow area, and on 21 July pulled one bird from a burrow. We found no cvidence of storm-petrels nesting there in 1962 nor did Arneson (1977) in 1977. Fork-tailed storm-petrels more commonly nest in Alaska in the Aleutian Islands and south near the coast in the Gulf of Alaska (American Ornithologists' Union 1983). 
Double-crested cormorant (Phalacrocorax auritus). Rspm, FCsr (30 April-25 September). Specimen: UAM3135.

Cormorants nested on offshore islands and migrated along the coast. We recorded low numbers of cormorants migrating past Cape Peirce in 1976. Cormorants were seen at the Walrus Islands, in Togiak Bay, and on the Togiak River. They nested on Shaiak Island (Fig. 11) and on Bird Rock near Cape Newenham (present study) and on Summit Island in June-July 1977 (Arneson 1977). They were common in Chagvan Bay during 23-28 July 1969 J. L. Hout, personal communication). Birds foraged in rivers, nearshore waters, and inshore waters in all areas where they were observed. Cormorants from Shaiak Island congregated on beaches in Nanvak Bay during summer and flew overland to and from Shaiak Island daily.

The number of nesting pairs on Shaiak Island varied from 125 in 1973 to 300 in 1976. Nests were clustered on low, broad ledges, on flat rocks, or on the ground, mostly on the highest parts of the island. Sixty clutches averaged $4.23 \pm 0.90$ eggs per nest (range, $3-5$ ) on 14 June 1973 . Thirteen pairs fledged $1.62 \pm 0.18$ young per nest (range, 1-3) in 1976; cgg laying began about 7 June, hatching was from 2 to $10 \mathrm{July}$, and fledging was from 7-29 August 1976. At least six pairs on partially completed nests were on Bird Rock on 21 May 1973, and J.L. Hout (personal communica-

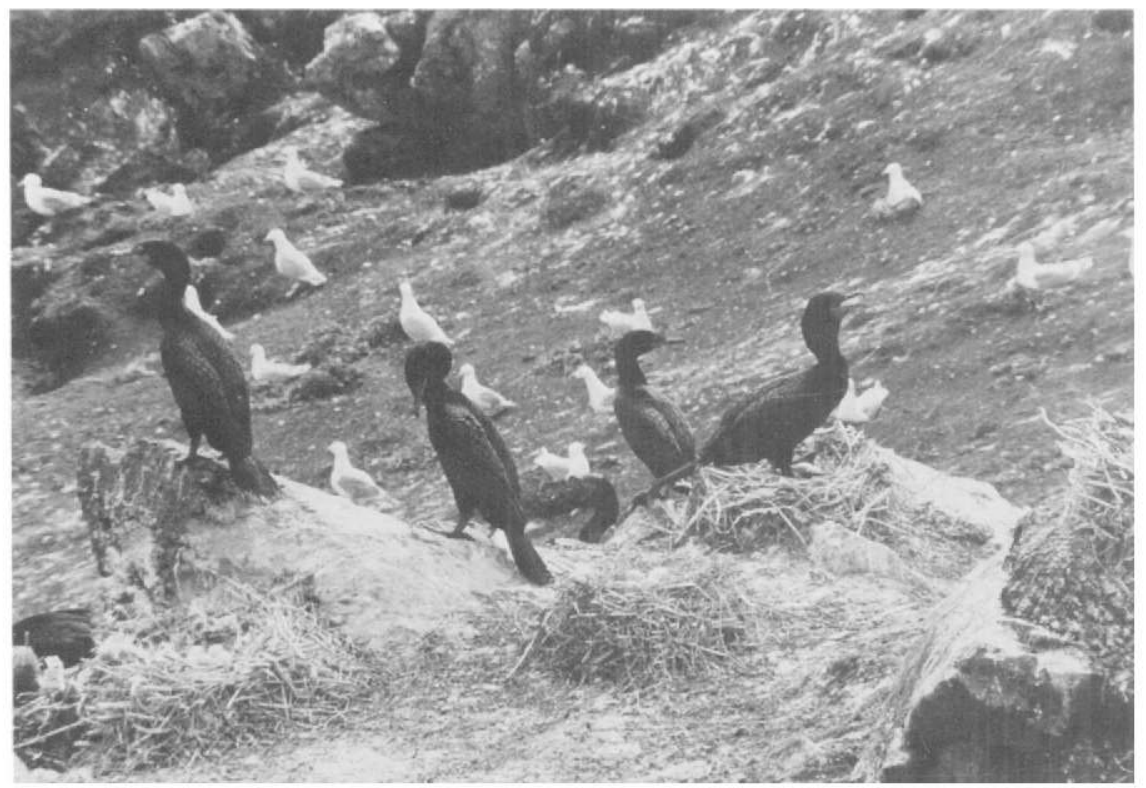

Fig. 11. Double-crested cormorants and nests with eggs; Shaiak Island, 14 June 1973. Photo by M. H. Dick. 
tion) found birds there on 26 July 1969 . This information documents the range extension reported in American Ornithologists' Union (1983).

Pelagic cormorant (Phalacrocorax pelagicus). Aspm, Asr (18 April27 September). Specimens: UAM2622, UAM2623, and YDNWR (no accession number).

Cormorants were found along the coast and in estuaries. They migrated past Cape Peirce in spring (peak migration rate of 260 birds per hour on 2 May 1973) and may migrate along the coast in late fall. J. G. King (unpublished) saw more than 10,000 pelagic cormorants near Hagemeister Island on 30 April 1974. Generally, migration along the coast occurred from 28 April to 1 June; however, D. I. Eisenhauer (personal communication) found birds in Chagvan Bay on 18 April 1973. Birds nested on all suitable coastal cliffs (Fig. 12) from the Beluga Peaks in Goodnews Bay to the Walrus Islands. The following are breeding population estimates (from Sowls et al. [1978] except as noted): Big Beluga, 420 pairs (DNW photo); Little Beluga, 30 pairs (DNW photo); Cape Peirce, 350 pairs (nest, eggs, MHD photo; nest, young, MRP photo); Shaiak Island, 50 pairs (MHD photo; MRP photo); Hagemeister Island, 345 pairs; Walrus Islands, 9,780

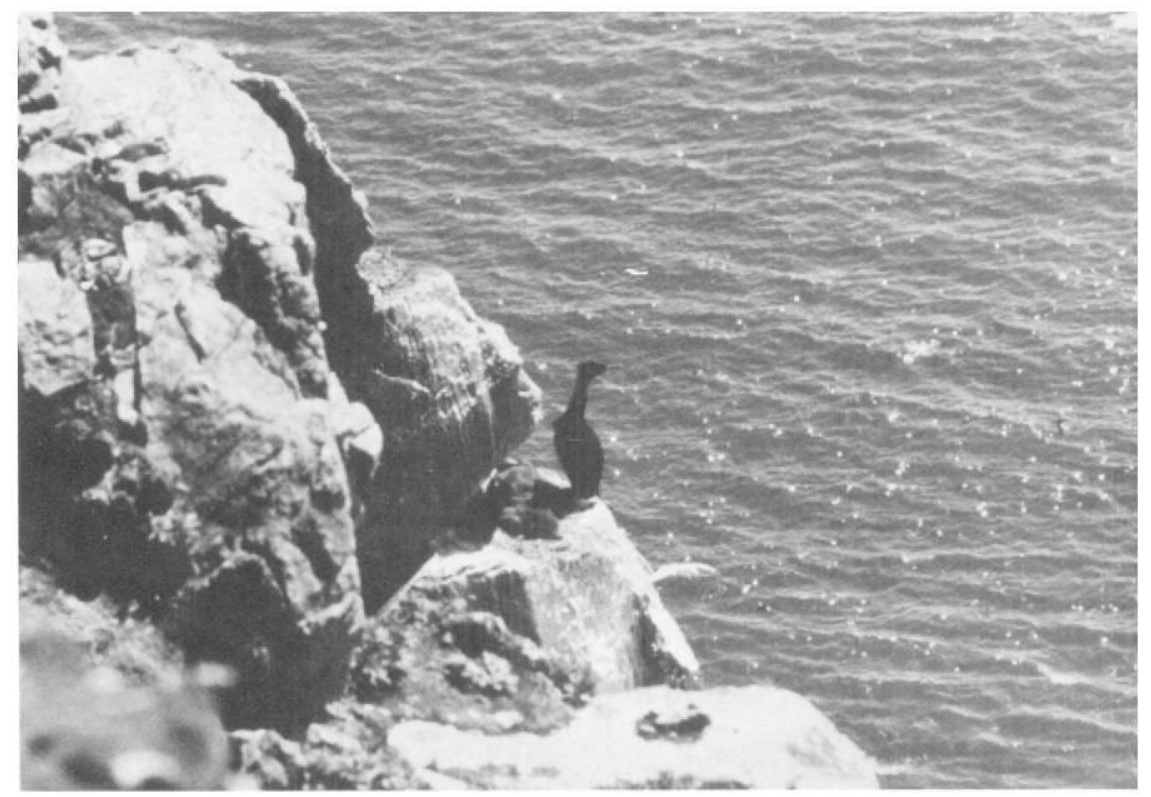

Fig. 12. Typical nest site used by pelagic cormorants on coastal cliffs and islands; Shaiak Island, 17 July 1976. Photo by M. R. Petersen. 
pairs; Summit Island, 530 pairs; and at Nunavachak Lake, about 300 pairs (present study).

At Cape Peirce, pairs had arrived at nest sites by late April 1973 and 1976. Birds laid eggs from mid-May to early July, hatched young in mid-June to late July, and the young fledged from early August to early September (Table 2). J. G. King (unpublished) found nests with eggs on 3 July 1964 . Numbers of pelagic cormorants in the area declined gradually in fall, and by 25 September 1973 only 11 birds remained at Cape Peirce.

Red-faced cormorant (Phalacrocorax urile). Rsr. Specimen: UAM3136.

This cormorant nested on the coast in some years. We found 2 pairs at Big Beluga in 1974 (DNW photo) and 1-7 pairs at Cape Peirce between 4 May and 1 September 1970-76, about a dozen pairs nested on the cliffs at Cape Peirce 25-29 June 1970 (H. P. Brokaw, unpublished), and Sowls et al. (1978) reported 21 pairs at Hagemeister Island in 1977. We found fewer than 100 pairs on Round Island in 1962; however, none were found there in 1974 (T. J. Eley, unpublished), 1976 (R. MacIntosh, unpublished), or 1977 (Arneson 1977). Because they nested among pelagic cormorants, numbers of red-faced cormorants may have been underestimated. This information documents red-faced cormorant nesting in the region as reported in Kessel and Gibson (1978).

\section{Frigatebird (Fregata sp.). VRv.}

Petersen saw a bird with immature plumage at Cape Peirce on 20 May 1976. The frigatebird was flying and gliding along the dunes and cliffs, then west out to sea. This bird was far out of its normal range and further north along the Pacific coast than frigatebirds have previously been recorded. Magnificent frigatebirds ( $F$. magnificens) have been reported on the Pacific coast to south-coastal Alaska, although it usually ranges from northern California to northern Peru when along the Pacific coast (American Ornithologists' Union 1983). Neither of the other two species have been reported along the Pacific coast.

Tundra swan (Cygnus columbianus). Uspm, Usr, Cfm (23 April-7 October).

Swans migrated along the coast and nested on the coastal plain. We found swans in ice-free ponds during spring migration near Nanvak, Goodnews, and Chagvan bays. Swans migrated past Cape Peirce in spring; they were seen between Platinum and Cape Peirce on 23 April 1981 (C. P. Dau, unpublished). Swans were seen near Nyac (Mindell 1983), at the Kisaralik River (17-18 and 28 August 1985; M. Brown et al., unpublished), at the Kwethluk River (10 and 18 July 1985; M. Brown 


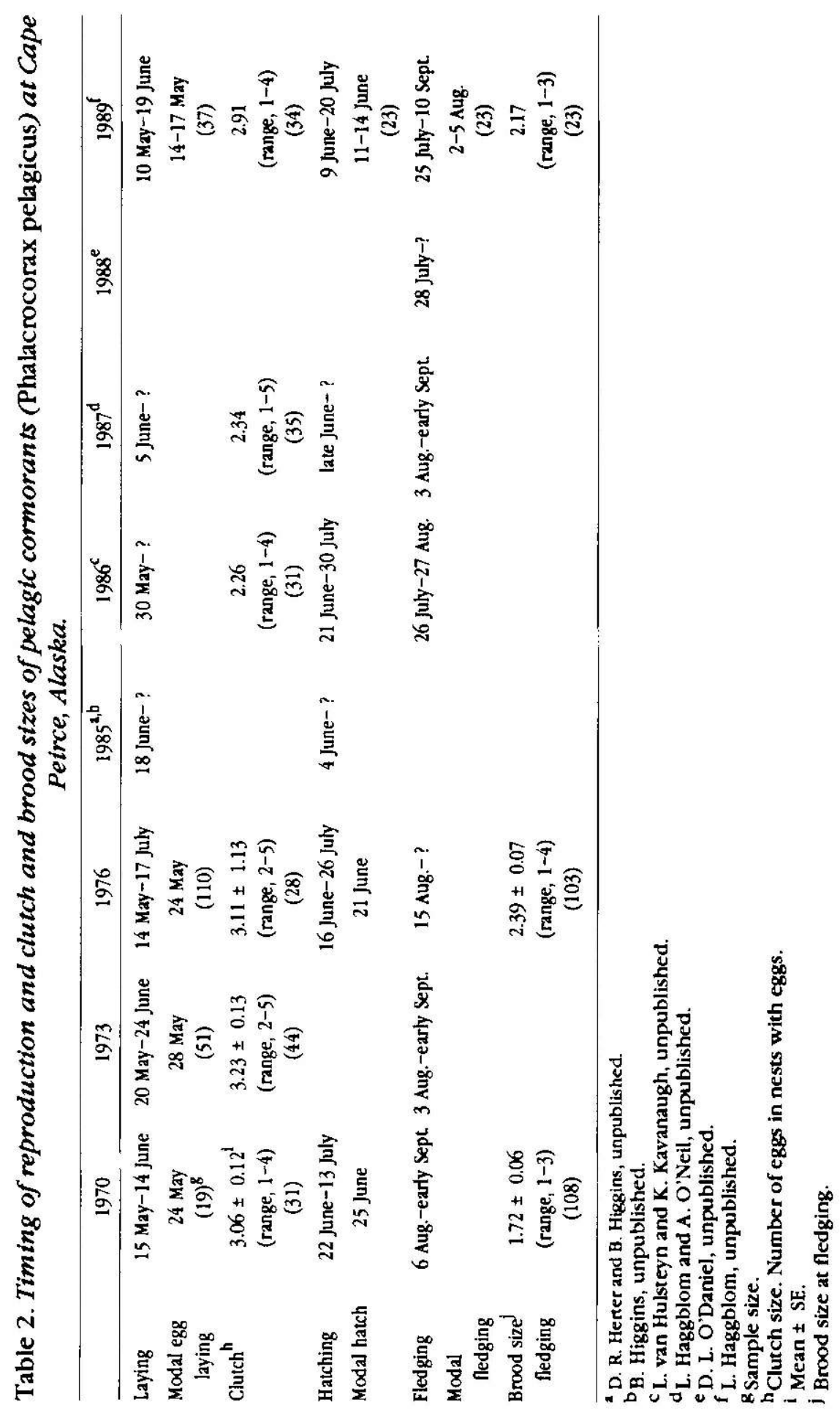


et al., unpublished) and at the Eek River (17, 22, and 24-26 June 1985; M. Brown et al., unpublished). Swans migrated through the Tuluksak River area and along the coast in late fall (Table 3).

Table 3. Use of Nanvak, Chagvan, and Goodnews bays and adjacent wetlands by abundant, common, and fairly common migrating waterfowl and shorebirds.

\begin{tabular}{|c|c|c|c|c|}
\hline $\begin{array}{l}\text { Common } \\
\text { name }\end{array}$ & $\begin{array}{l}\text { Estimated }^{2} \\
\text { population } \\
\text { in spring }\end{array}$ & $\begin{array}{l}\text { Migration } \\
\text { dates } \\
\text { (peak) }\end{array}$ & $\begin{array}{l}\text { Estimated } \\
\text { population } \\
\text { in fall }\end{array}$ & $\begin{array}{c}\text { Migration } \\
\text { dates } \\
\text { (peak) }\end{array}$ \\
\hline Tundra swan & & & hundreds & Sept.-Oct. \\
\hline $\begin{array}{l}\text { White-fronted } \\
\text { goose }\end{array}$ & hundreds & 30 Apr. -5 May & hundreds & $\begin{array}{l}7 \text { Aug. }-7 \text { Sept. } \\
\text { (mid-Aug.) }\end{array}$ \\
\hline Emperor goose & $\begin{array}{l}\text { tens of } \\
\text { thousands }\end{array}$ & $\begin{array}{c}18 \text { Apr--9 June } \\
\text { (mid-May) }\end{array}$ & $\begin{array}{l}\text { tens of } \\
\text { thousands }\end{array}$ & $\begin{array}{l}19 \text { Aug. }-6 \text { Oct. } \\
\text { (late Aug.) }\end{array}$ \\
\hline Brant & $\begin{array}{l}\text { tens of } \\
\text { thousands }\end{array}$ & $\begin{array}{c}28 \text { Apr.-17 June } \\
\text { (mid-May) }\end{array}$ & $\begin{array}{l}\text { tens of } \\
\text { thousands }\end{array}$ & $\begin{array}{l}10 \text { Aug. }-6 \text { Oct. } \\
\text { (early Sept.) }\end{array}$ \\
\hline Canada goose & $\begin{array}{l}\text { tens of } \\
\text { thousands }\end{array}$ & 20 Apr.- 10 June & thousands & $\begin{array}{l}\text { mid-Aug,-mid-Oct. } \\
\text { (early Sept.) }\end{array}$ \\
\hline $\begin{array}{l}\text { Green-winged } \\
\text { teal }\end{array}$ & hundreds & $\begin{array}{l}\text { 1-19 May } \\
\text { (1 May) }\end{array}$ & thousands & Aug. - Oct. \\
\hline Mallard & hundreds & $\begin{array}{l}28 \text { Apr. }-17 \text { May } \\
\text { (2 May) }\end{array}$ & thousands & 5 Sept. $-100 \mathrm{ct}$. \\
\hline Northem pintail & thousands & $\begin{array}{c}27 \text { Apr }-17 \text { May } \\
\text { (2-4 May) }\end{array}$ & thousands & $\begin{array}{l}28 \text { July-6 Oct. } \\
\text { (Sept.) }\end{array}$ \\
\hline American wigeon & hundreds & $\begin{array}{l}29 \text { Apr }-18 \text { May } \\
\text { (1 May) }\end{array}$ & hundreds & 25 Aug.-Oct. \\
\hline Greater scaup & hundreds & $\begin{array}{c}23 \text { Apr. }-31 \text { May } \\
(10-15 \text { May })\end{array}$ & thousands & Sept $-0 \mathrm{ct}$. \\
\hline Common eider & thousands & $\begin{array}{l}\text { early Apr.- } \\
\text { early June }\end{array}$ & thousands & Sept.-Nov. \\
\hline King eider & $\begin{array}{l}\text { tens of } \\
\text { thousands }\end{array}$ & $\begin{array}{c}\text { Apr.-June } \\
\text { (early May) }\end{array}$ & thousands & July-? \\
\hline Steller's eider & $\begin{array}{c}\text { tens of } \\
\text { thousands }\end{array}$ & $\begin{array}{l}\text { Apr.-14 June } \\
(5-13 \text { May) }\end{array}$ & thousands & $\begin{array}{c}4 \text { Aug.-Oct. } \\
\text { (Aug., early Oct.) }\end{array}$ \\
\hline Oldsquaw & hundreds & 18 Apr. -12 June & hundreds & $\begin{array}{l}\text { Aug.-Oct. } \\
\text { (late Sept.) }\end{array}$ \\
\hline Black scoter ${ }^{b}$ & $\begin{array}{l}\text { tens of } \\
\text { thousands } \\
\text { thousands }\end{array}$ & $\begin{array}{l}23 \text { Apr.-20 June } \\
\text { (1 May) } \\
\text { mid-June-late July } \\
\text { (11 July) }\end{array}$ & 1,000 's & Aug.-Oct. \\
\hline Surf scoter & hundreds & late June-mid-July & & \\
\hline
\end{tabular}


Table 3. Continued.

\begin{tabular}{|c|c|c|c|c|}
\hline $\begin{array}{l}\text { Common } \\
\text { name }\end{array}$ & $\begin{array}{l}\text { Estimated }^{2} \\
\text { population } \\
\text { in spring }\end{array}$ & $\begin{array}{l}\text { Migration } \\
\text { dates } \\
\text { (peak) }\end{array}$ & $\begin{array}{c}\text { Estimated } \\
\text { population } \\
\text { in fall }\end{array}$ & $\begin{array}{l}\text { Migration } \\
\text { dates } \\
\text { (peak) }\end{array}$ \\
\hline \multicolumn{5}{|l|}{ White-winged ${ }^{b}$} \\
\hline scoter & $\begin{array}{l}\text { hundreds } \\
\text { hundreds }\end{array}$ & $\begin{array}{c}28 \text { Apr- }-4 \text { June } \\
\text { (4-12 May) } \\
\text { June-July } \\
\text { (11 July) }\end{array}$ & hundreds & 15 Aug. -25 Sept. \\
\hline Common goldeneye & $\begin{array}{l}\text { less than one } \\
\text { hundred }\end{array}$ & Apr.-June & & \\
\hline $\begin{array}{l}\text { Red-breasted } \\
\text { merganser }\end{array}$ & hundreds & 28 Apr. -17 June & & \\
\hline Sandhill crane & hundreds & 1 May-11 June & hundreds & 14 Aug. -7 Sept. \\
\hline $\begin{array}{l}\text { Black-bellied } \\
\text { plover }\end{array}$ & hundreds & 1 May-8 June & hundreds & $\begin{array}{l}28 \text { June-26 Sept. } \\
\text { (July) }\end{array}$ \\
\hline $\begin{array}{l}\text { Pacific } \\
\text { golden-plover }\end{array}$ & $\begin{array}{l}\text { less than one } \\
\text { hundred }\end{array}$ & 7-17 May & hundreds & $\begin{array}{l}16 \text { Aug.-1 Oct. } \\
\text { (mid-Scpt.) }\end{array}$ \\
\hline Spotted sandpiper & $\begin{array}{l}\text { less than one } \\
\text { hundred }\end{array}$ & late May & $\begin{array}{l}\text { less than one } \\
\text { hundred }\end{array}$ & July \\
\hline Whimbrel & & & hundreds & $\begin{array}{l}\text { June-Sept. } \\
\text { (Aug.) }\end{array}$ \\
\hline Bar-tailed godwit & & & thousands & $\begin{array}{l}\text { mid-Aug.-Sept. } \\
\text { (mid-Aug.) }\end{array}$ \\
\hline Sanderling & & & hundreds & $\begin{array}{l}5 \text { July-Sept. } \\
\text { (early Sept.) }\end{array}$ \\
\hline Western sandpiper & thousands & $\begin{array}{l}\text { 1-17 May } \\
(1-3 \text { May })\end{array}$ & thousands & $\begin{array}{l}25 \text { June-Sept. } \\
\text { (20 Aug.) }\end{array}$ \\
\hline Rock sandpiper & $\begin{array}{l}\text { tens of } \\
\text { thousands }\end{array}$ & $\begin{array}{l}\text { Apr.-27 May } \\
(7-17 \text { May) }\end{array}$ & $\begin{array}{l}\text { tens of } \\
\text { thousands }\end{array}$ & $\begin{array}{l}\text { late July-0ct. } \\
\text { (13-17 Sept.) }\end{array}$ \\
\hline Dunlin & hundreds & 3-24 May & thousands & mid-Aug.-late Sept. \\
\hline $\begin{array}{l}\text { Shortbilled } \\
\text { dowitcher }\end{array}$ & & & hundreds & late-July-Sept. \\
\hline $\begin{array}{l}\text { Long-billed } \\
\text { dowitcher }\end{array}$ & & & hundreds & $\begin{array}{l}\text { late July-Sept. } \\
\text { (late Aug.) }\end{array}$ \\
\hline $\begin{array}{l}\text { Red-necked } \\
\text { phalarope }\end{array}$ & & & hundreds & mid-July-mid-Sept. \\
\hline
\end{tabular}

Estimates are order of magnitude numbers expected to be in the area during the peak migration period.

${ }^{b}$ Spring migration of pairs and molt migration of males in mid-summer. 
We found birds nesting at Ilanik Lakes (DNW photo) and in all drainages from the Tuluksak River to the Arolik River. Swans were reported nesting up the Goodnews River (B. Huffmon, personal communication).

We found three pairs and one nest with six eggs in a $260-\mathrm{km}^{2}$ area near Ilanik Lake on 17 June 1974. Thirteen pairs seen on 12 September 1977 near the edge of our area (from the lower Eek to Kanektok rivers) had 0-6 fledged young each (2.2 young per pair or 3.2 young per successful pair). A pair at Jacksmith Bay had four young on 9 September 1976. We found flightless birds on the lower Eek and Kanektok rivers; molting flocks ranged from 10 to 150 birds, and most flocks had more than 50 birds. Two tundra swans were at Crooked Island on 25 June 1977 (P. D. Arneson and D. B. McDonald, personal communication).

Greater white-fronted goose (Anser albifrons). FCspm, Rsr?, FCfm (30 April-24 September).

Greater white-fronted geese migrated and molted along the coast and were found inland. Geese migrated past Cape Peirce in spring from 30 April to 5 May (flocks to 23 individuals) and in fall from 7 August to 7 September 1976 and 19 to 31 August 1973 (in flocks of up to 45 individuals). Flocks of flightless adults were seen at Chagvan Bay on 21-29 July 1969 and a flock of 12 migrating birds flew south over Nanvak Bay on 24 September 1971 J. L. Hout, personal communication). Inland, in the Kilbuck and Ahklun mountain region, adults were seen near the Kisaralik River in August 1976 (D. R. Money, unpublished) and one was seen at the Eek River on 22 June 1985 (M. Brown et al., unpublished). We found adults near the Togiak River in August 1973, and we saw one on the Tuluksak River on 27 July 1983.

Snow goose (Chen caerulescens). Rspm, Rfm.

Snow geese migrated along the coast in spring and fall. Three flocks of 150,100, and 75 snow geese passed Cape Peirce on 1 May 1976, and we suspect that birds may pass each fall along the coast of the study area en route to their staging areas on the Alaska Peninsula. On 14 September 1971, J. L. Hout (personal communication) observed 2 flocks of 20-30 birds passing Goodnews Bay, and R. Gill, Jr., and R. King (unpublished) found 165 and 25 birds at Goodnews and Chagvan bays, respectively, during an aerial survey on 6 October 1980. Mindell (1983) found them uncommon in the Nyac area 
Emperor goose (Chen canagicus). Aspm, VRsr, Afm (18 April8 October).

Emperor geese were abundant migrants along the coast and molted and nested in the area. We found emperor gecse at Goodncws Bay, Chagvan Bay, Nanvak Bay, and Cape Peirce during spring and fall migration (Table 3). In spring 1973, geese began migrating past Nanvak Bay by 28 April, peaked on 14 May, and continued to 6 June. One hundred flocks averaged $17.1 \pm 1.5$ birds per flock (range, 2-70). In 1976, spring migration began on 2 May, peaked on 16 May, and continued to 9 June. J. G. King (unpublished) reported 60,000 birds in Nanvak and Chagvan bays during spring migration (28 May 1964), and D. I. Eisenhauer (personal communication) found birds at Chagvan Bay by 18 April 1973 . Estimates made during aerial surveys using the coastal portion of the study include 11,351 in 1981 (23 April; C. P. Dau, unpublished), 7 in 1982 (3 May; C. P. Dau, unpublished), 2,459 in 1983 (25 April; C. P. Dau, unpublished), 92 in 1984 (28 April; C. P. Dau, unpublished), 1,061 in 1985 (12 May; C. P. Dau and R. J. King, unpublished), 2,326 in 1986 (4 May; C. P. Dau and R. J. King, unpublished), 1,152 in 1987 (1 May; R. J. King and C. P.Dau, unpublished) and 1,415 in 1989 (4 May; R. J. King and C. P. Dau, unpublished).

Migrant adults began arriving at Cape Peirce and Nanvak Bay on 25 August 1973 and 19 August 1976, and pairs with families first appeared on 25 August 1973 and 27 August 1976. Family groups were migrating through Goodnews Bay area on 13-15 September 1977. At Cape Peirce during fall migration in 1973, 279 families averaged $2.96 \pm 0.10$ young per family (range, 1-7); in 1976, 35 familics there averaged $2.49 \pm 1.22$ young per family (range, 1-5) and $21 \%$ of 483 birds were young. J. L. Hout (personal communication) observed that 40 families averaged $3.23 \pm 0.23$ young per family (range, 1-7) on 16-30 September 1971 at Chagvan Bay, Nanvak Bay, and Cape Peirce. Nanvak and Chagvan bays are important staging areas for emperor gecse, particularly in fall when family groups feed heavily on crowberries (Empetrum nigrum) and eelgrass. Numbers of birds found during aerial surveys using the coastal portion of the study area in late fall include 0 in 1979 (1 October; R. Gill, Jr., and B. Conant, unpublished), 8 in 1980 (6 October; R. Gill, Jr., and R. King, unpublished), 25 in 1981 (4 October; R. E. Gill, Jr., unpublished), 0 in 1982 (6 October; R. J. King and K. S. Bollinger, unpublished), 0 in 1985 (10 October; R. J. King and W. D. Eldridge, unpublished), 20 in 1987 (2 October; R. J. King and W. D. Eldridge, unpublished), 12 in 1988 and 15 in 1989 (8 and 7 October, respectively; R. J. King and L. Denlinger, unpublished).

D. R. Herter and D. Lloyd (personal communication) found flightless birds at Cape Peirce in 1981, and D. R. Herter et al. (personal communication) found 1,60 , and 6 emperors there on 7 and 9 June and 11 July 1984, respectively. We also found adults in Chagvan Bay on 20-22 July 
1974 but not on 17 July 1986; P. D. Arneson and D. B. McDonald (unpublished) saw one bird on 9 July 1977 at Hagemeister Island. Nesting was recorded at Carter by Twitchell (in Gabrielson and Lincoln 1959); we saw birds that were possibly nesting at Jacksmith Bay in 1974. Three cmperor geese were seen on the lower Kisaralik River just outside our area in July 1984 (D. A. Boyce and S. J. Fristensky, unpublished).

Brant (Branta bernicla). Aspm, Rsr, Afm (23 April-8 October).

Brant migrated along the coast and occasionally nested there. In spring 1973, Brant migrated through Nanvak Bay from 28 April to 17 June, with the peak of migration on 15-18 May. They migrated past Cape Peirce from 28 April to 1 June 1976 at rates from $152 \pm 66.12$ birds per hour (6 days during 3-11 May, $3.62 \mathrm{~h}$ ) early in migration to 1,362 birds per hour $(2.1 \mathrm{~h})$ at peak migration on 12 May. Flocks of up to several thousand brant were in Chagvan Bay until 25 May 1987 (D. F. Parmelee and J. M. Parmelee, unpublished). Estimates of the number of brant along the coastal portion of the study arca included 32,000 in 1963 (28 May; J. G. King, unpublished), 15,022 in 1981 (23 April; C. P. Dau, unpublished), 515 in 1982 (4 May; C. P. Dau, unpublished), 1,877 in 1983 (25 April; C. P. Dau, unpublished), 5,484 in 1984 (28 April; C. P. Dau, unpublished), 11,319 in 1985 (12 May; C. P. Dau and R. J. King, unpublished), 7,149 in 1986 (4 May; C. P. Dau and R. J. King, unpublished), 6,090 in 1987 (1 May; R. J. King and C. P. Dau, unpublished), and 28,055 in 1989 (4 May; R. J. King and C. P. Dau, unpublished). P. D. Arneson and D. B. McDonald (personal communication) saw 3 brant at Crooked Island on 19-22 June 1977 , and D. R. Herter et al. (personal communication) saw as many as 150 brant at Cape Peirce on 7 June-4 July 1984. Black brant (B. $b$. nigricans) nested near Nanvak Bay where about 100 flightless young were found by J. G. King (unpublished) in 1963 and 1 by us in 1976. The closest primary nesting area for black brant is at Kuskokwim Bay (American Ornithologists' Union 1983) to the north and west of our study area.

Fall migrants first appeared in August primarily along the coast in Goodnews, Chagvan, and Nanvak bays (Table 3). One brant was seen inland at Eek River on 10 August 1976 (R. Baxter, unpublished). At Nanvak Bay, we found flocks of adult birds beginning 19 August 1973 and 1976 and flocks with young beginning 25 August 1973 and 28 August 1976. Fall migration peaked at Nanvak Bay from 1 to 4 September 1973, when there were 20,000 birds in the bay. From 27 August-16 September 1973, 34 family groups averaged $2.85 \pm 0.25$ young per pair (range, 1-7). Migration from Nanvak Bay began 21 September 1971 J. L. Hout, unpublished). During aerial surveys including both Nanvak and Chagvan bays, J. G. King (unpublished) recorded 32,000 brant on 28 May 1963 and 21,000 on 3 September 1963 . Most brant were gone from the area by early October. Estimates during aerial surveys of the entire coastal area in- 
cluded 0 in 1979 ( 1 October; R. Gill, Jr., and B. Conant, unpublished), 2 in 1980 ( 6 October; R. Gill, Jr., and R. J. King, unpublished), 0 in 1982 (6 October; R. J. King and K. S. Bollinger, unpublished), 0 in 1985 (10 October; R. J. King and W. D. Eldridge, unpublished), 245 in 1987 (2 October; R. J. King and W. D. Eldridge, unpublished), 12 in 1988, and 0 in 1989 (8 and 7 October, respectively; R. J. King and L. Denlinger). Nanvak and Chagvan bays are critical staging areas for Alaskan brant during spring and fall migration (Table 2).

Canada goose (Branta canadensis). Cspm, Usr, Afm (23 April10 October).

Two sizes of Canada geese occurred on the study area. The smaller, presumably cackling Canada gecse (B. c. minima), and the larger, presumably Taverner's Canada gecse (B. C. taverneri), migrated past Cape Peirce and along the coast during spring ( 30 April-10 June), and Taverner's type migrated inland to as far as the Tuluksak River (late May-early June). Migrants used the bays and estuarics on the study area (Table 3). Estimates from aerial surveys in spring included 10,000 birds in 1963 J. G. King, unpublished), 295 in 1981 (23 April; C. P. Dau, unpublished), 3,040 in 1982 (3 May; C. P. Dau, unpublished), 4,126 in 1983 (25 April; C. P. Dau, unpublished), 512 in 1984 (28 April; C. P. Dau, unpublished), 90 in 1985 (12 May; C. P. Dau and R. J. King, unpublished), 2 in 1986 (1 May; C. P. Dau and R. J. King, unpublished), 1,189 in 1987 (1 May; R. J. King and C. P. Dau, unpublished) and 208 in 1989 ( 4 May; R. J. King and C. P. Dau, unpublished). In fall (late September through early October), numbers of Canada geese obscrved during aerial surveys included 310 in 1979 (1 October; R. Gill, Jr. and B. Conant, unpublished), 2,270 in 1982 ( 6 October; R. J. King and K. S. Bollinger, unpublished), 1,182 in 1985 (10 October; R. J. King and W. D. Eldridge, unpublished), 2,335 in 1987 (2 October; R. J. King and W. D. Eldridge, unpublished), 2,188 in 1988, and 295 in 1989 ( 8 and 7 October, respectively; R. J. King and L. Denlinger, unpublished). Generally, fall migrants first occurred along the coast in mid-August, although migrants were noted past Nanvak Bay as early as 24 June 1970. Fall migration peaked past Nanvak Bay on 5 September 1973. Fall migration was gencrally completed by carly October (see previous dates in this paragraph). Fall migration at the Tuluksak River occurred through September and continued to as late as 10 October.

We found Canada geese (presumed to be B. c. taverneri) brecding at the Tuluksak River (in 1974 and 1983, but not in other ycars) and the Salmon River, and they may have nested near the Kisaralik River and at the Ilanik Lakes. Twelve Canada geese were along the Kisaralik River on 17 June 1987 (B. J. McCaffery, personal communication), and birds were scen at the Eek River on 26 June 1985 (M. Brown ct al., unpublished), 
and B. Huffmon (personal communication) reported nesting birds at Goodnews River. We found flightless birds on the Salmon River (Goodnews), the Kinegnak River, Chagvan Bay, and Nanvak Bay, and J. L. Hout (personal communication) found 200-250 flightless birds in Chagvan Bay on 23-28 July 1969. D. R. Herter and D. Lloyd (personal communication) found flocks of 10-30 birds at Nanvak Bay from 17 to 25 June 1981, and D. R. Herter et al. (personal communication) found 14-57 birds there on 25-29 July 1984 .

\section{Green-winged teal (Anas creoca). Aspm, Csr, Rfm (28 April-8 October).}

Teal migrated along the coast and nested throughout the area. Male green-winged teal of the European type (A. C. crecca) paired to females of unknown subspecies were found during migration at Cape Peirce on 29 May 1973, 10,11, and 17 May 1976 and at the Tuluksak River on 6 June 1974. A single male was at Cape Peirce on 10 June 1981 (D. R. Herter and D. Lloyd, personal communication). All other male green-winged teal that were closely inspected were of the American type (A. C. carolinensis). Teal were abundant at Cape Peirce during the 1976 spring migration (1-19 May, peak 1 May). Between 5 and 17 May 1973, the sex ratio of 87 migrant birds in mixed flocks and pairs at Nanvak Bay was 1.3 male to 1.0 female. Between 18 May and 10 June, migrant males (singly or in groups of up to three) were seen almost exclusively. We saw a few birds during late August and early September at Cape Peirce, suggesting that some may migrate through the study area in fall. J. L. Hout (personal communication) saw one bird near Nanvak Bay on 19 September 1971. No teal were seen during acrial survcys of the entire coastal area in late fall (1-10 October) 1979 (R. Gill, Jr., and B. Conant, unpublished), 1980 (R. Gill, Jr., and R. King, unpublished), 1982 (R. J. King and K. S. Bollinger, unpublished), and 1985 (R. J. King and W. D. Eldridge, unpublished); however, 1,110 were seen in 1987 (2 October; R. J. King and W. D. Eldridge, unpublished), 257 in 1988 and 284 in 1989 (8 and 7 October, respectively; R. J. King and L. Denlinger, unpublished).

Teal nested at the Salmon River, the Tuluksak River, near Nyac (Mindell 1983), Togiak Lake, the Togiak River, Kagati Lake (M. J. Fry, unpublished), the Kanektok River (J. L. Hout, personal communication), Goodnews Bay, Chagvan Bay, and Nanvak Bay, and probably nested at the Kisaralik River. At the Tuluksak River, we found 6-20 pairs or broods each year in a $260-\mathrm{km}^{2}$ area and in 1983 found 3.3 pairs per square kilometer in riparian habitats. Eighteen broods of mostly feathered young averaged 5.6 young (range $2-8$ ) there, and small downy young were seen beginning on 6 June. At the Salmon River, we found one brood with nine ducklings on 29 July 1986 . Green-winged teal were seen at the Kisaralik River on 12-24 August 1985 (from 1 to $>15$ birds, 5 days; M. Brown et al., unpublished) and 17 June 1987 (B. J. McCaffery, personal communica- 
tion), seen at the Kwethluk River on 21 July 1985 ( 1 bird; M. Brown et al., unpublished), and seen at the Eek River on 24 (1 bird) and 26 June 1985 ( $<5$ birds; M. Brown et al., unpublished). Two pairs were in marshy ponds near Chagvan Bay on 20 May 1987 (D. F. Parmelee and J. M. Parmelee, unpublished). At Cape Pcirce, broods were found on 25 June (one with eight downies) and 16 July 1981 (one with seven almost fully feathered young; D. R. Herter and D. Lloyd, personal communication), on 25 June 1984 (one with three downies, 4-5 days old; D. R. Herter et al., personal communication), and on 21 July 1970 (one with six partially feathered young).

Baikal teal (Anas formosa). VRv.

Petersen saw a single male in definitive alternate plumage in a small pond near Nanvak Bay on 1 May 1976. Previous observations in Alaska are of birds north of the Bering Strait and the Pribilof Islands (Kessel and Gibson 1978).

Malland (Anas platyrhynchos). Cspm, Rsr, Cfm (28 April-10 October).

Mallards nested throughout the study area and migrated along the coast. We found a $\mathrm{few}$ pairs of mallards using ice-free areas of Nanvak Bay and nearby ponds during the 1976 spring migration (28 April-17 May; peak 2 May) and a few groups of one to four birds during the 1973 fall migration (5-16 September 1973). Inland, mallards nested at the Tuluksak and Salmon rivers and were seen near Togiak lake in summer. Mallards were also found at the Kwethluk River (one on 23 July 1985; M. Brown et al., unpublished), at the Kancktok River (White and Boyce 1978 ; J. L. Hout, personal communication), and on the Eck River (R. Baxter, unpublished; M. Brown et al., unpublished). They were scen in coastal areas in summer near Goodnews and Chagvan (D. F. Parmelec and J. M. Parmclee, unpublished) bays, and nested at Nanvak Bay in 1981 (D. R. Herter and D. Lloyd, personal communication). A male mallard was seen near the mouth of Nanvak Bay on 25 Junc 1970 (H. P. Brokaw, unpublished). Aerial surveys of the coastal area in late fall included 60 mallards scen in 1980 ( 6 October; R. Gill, Jr., and R. King, unpublished), 115 in 1982 (6 October; R. J. King and K. S. Bollinger, unpublished), 200 in 1985 ( 10 October; R. J. King and W. D. Eldridge, unpublished), 20 in 1987 ( 2 October; R. J. King and W. D. Eldridge, unpublished), 2,956 in 1988 and 1,581 in 1989 (8 and 7 October, respectively; $R$. J. King and $L$. Denlinger, unpublished).

Mallards nested in 5 of 11 years along $48 \mathrm{~km}$ of major streams at the Tuluksak River. We found one pair in 1962; no mallards in 1974, 1976, $1980,1981,1986$, and 1987; one femalc with young and a single femalc in fall 1977; a probably nesting female in 1978; and a single femalc with 
young in 1979 and 1983. D. R. Herter and D. Lloyd (unpublished) found a female and three young near Nanvak Bay in 1981.

Northern pintail (Anas acuta). Aspm, Csr, Afm (23 April10 October).

Pintails nested throughout the study area and migrated along the coast. We found pintails migrating past Cape Peirce during 27 April19 May 1973 (peak, 4 May) and 28 April-17 May 1976 (peak, 2 May). C. P. Dau (unpublished) reported 15 birds between Platinum and Security Cove during an aerial survey on 23 April 1981; D. F. Parmelee and J. M. Parmelee (unpublished) observed one to seven birds occasionally at Chagvan Bay from 20 to 24 May 1987 . Birds used areas flooded by meltwater near Nanvak Bay in spring (MRP photo). The sex ratio of 347 birds in mixed flocks seen at Nanvak Bay between 1 and 17 May 1973 was 2.6 males to 1.0 female. One pair was in the marsh at Cape Peirce on 28 June 1970 (H. P. Brokaw, unpublished). The first fall migrants (males) appeared at Cape Peirce on 28 July 1970 and 8 August 1976, and pintails were seen throughout fall. There were several thousand at Nanvak Bay on 27 August 1970, and roughly 800 birds there on 22 September 1973. We found migrants at Goodnews and Chagvan bays on 12-15 September 1977, and J. L. Hout (personal communication) found pintails in Nanvak Bay on 25 September-1 October 1971. Estimates of pintails during late fall surveys of the entire coastal area included 6,803 in 1980 (6 October; R. Gill, Jr., and R. King, unpublished), 385 in 1982 (6 October; R. J. King and K. S. Bollinger, unpublished), 665 in 1985 (10 October; R. J. King and W. D. Eldridge, unpublished), 1,956 in 1987 (2 October; R. J. King and W. D. Eldridge, unpublished), 2,804 in 1988 and 217 in 1989 (8 and 7 October, respectively; R. J. King and L. Denlinger, unpublished).

We found birds nesting at the Salmon River, the Tuluksak River, the Kisaralik River, Goodnews Bay, Chagvan Bay, and Nanvak Bay; J. G. King (unpublished) reported a female on six eggs at Nanvak Bay on 3 July 1963, and D. R. Herter and D. Loyd (personal communication) found a female with four ducklings on 3 July 1981. Pintails nested at Kagati Lake (M. J. Fry, unpublished) and probably nested along the Kanektok River (White and Boyce 1978); M. Brown et al. (unpublished) found birds at the Eek River on 17-24 June 1985; P. D. Ameson and D. B. McDonald (personal communication) found nesting birds at Crooked Island in June 1977. At the Tuluksak and Kisaralik rivers, we found 12 females with 1 to 9 young ( $x=4.5$ young per brood) and 4 newly fledged broods on $24 \mathrm{July}-13$ August. Mindell (1983) considered them uncommon near Nyac. B. J. McCaffery (personal communication) found them at the Kisaralik River on 17 June 1987. Flightless adults were in Chagvan Bay on 21-29 July 1969 J. L. Hout, personal communication). We found pintails in Nanvak 
Bay in June-July 1970 and J. G. King (unpublished) reported 5,000 or more birds in Chagvan Bay in midsummer 1963-64.

Northern shoveler (Anas clypeata). Rspm, VRfm.

One to three pairs were seen at Nanvak Bay on 4 June 1969, on 6 days during 4-13 May 1973, and on 5 days during 30 April-10 May 1976. Small flocks of males were there on 15-18 May 1973. J. L. Hout (unpublished) found 2 birds at Nanvak Bay on 3-12 June 1969; a few small flocks of up to 12 northern shovelers were seen there during 26 August-7 September 1973 and 25 August 1976.

\section{Gadwall (Anas strepera). VRv.}

A bird was seen at Carter by J. G. King on 6 September 1963 (Kessel and Gibson 1978). Gadwalls are generally more common along the Alaska Peninsula, where they nest (Gill et al. 1981).

American wigeon (Anas americana). Cspm, Usr, FCfm (29 April8 October).

Wigeons nested in the Kilbuck and Ahklun mountains and migrated along the coast. We frequently found a few pairs and small groups of male wigeons in areas flooded by meltwater near and in Nanvak Bay during spring migration (4-18 May 1973; 29 April-14 May 1976-peak, 1 May 1976). A pair was in Chagvan Bay on 26 May 1987 (D. F. Parmelee and J. M. Parmelee, unpublished). Two wigeons were seen during an aerial survey of the coast on 23 April 1981 (C. P. Dau, unpublished) and 108 on 1 May 1987 (R. J. King and C. P. Dau, unpublished). A few birds, including a flock of 17 basic-plumaged males, were observed during fall migration (25 August-16 September 1973) at Cape Peirce, and R. E. Gill, Jr., and R. King (unpublished) found 200 wigeons in Chagvan Bay during an aerial survey on 6 October 1980.

Birds nested in the Kilbuck and Ahklun mountains and were seen along the coast in summer. Males and females were seen in July at Goodnews Bay (1974), Chagvan Bay (1974), and the Togiak River mouth (1962); D. A. Boyce and S. J. Fristensky (unpublished) and M. Brown et al. (unpublished) recorded them at the Kisaralik River, M. Brown et al. (unpublished) found one bird at the Kwethluk River on 21 July 1985, and M. Brown et al. (unpublished) found wigeons at the Eck River on 1727 June 1985. E. H. Miller (unpublished) saw one wigeon in a freshwater pool on Round Island on 13-14 June 1972. At the Tuluksak River, small downies were found on 20 July 1962 and 22 July 1976, large downies on 20 July 1986 , partly feathered young on 30 July 1987 , and well feathered young on 18 July 1979 . We found two to four pairs or broods at the Tuluksak River ( $48 \mathrm{~km}$ of streams) in most years. A partly feathered 
duckling was at the Salmon River on 29 July 1986. A brood of partly downy young was at the Togiak River on 6 August 1973. During aerial surveys of the coastal area, 25 and 130 wigeons were counted on 8 October 1988 and 7 October 1989, respectively (R. J. King and L. Denlinger, unpublished).

Redhead (Aythya americana). VRv.

A single redhead was seen at Cape Peirce on 25, 27, and 28 June 1984 (D. R. Herter et al., personal communication). Redheads have been reported occasionally in western and southwestem Alaska (Kessel and Gibson 1978).

Greater scaup (Aythya marila). Aspm, Usr, Rfm (23 April- 23 September).

Scaup migrated and nested along the coast, probably nested in the Kilbuck and Ahklun mountains, and molted in the Ahklun Mountains. We frequently found several hundred spring migrants at Nanvak Bay during spring migration (28 April-10 June 1973 peak, 15 May; 30 April-31 May 1976 peak, 10 May). C. P. Dau (unpublished) reported 6 scaup from Platinum to Security Cove during an aerial survey on 23 April 1981 and 47, 407, 2, and 12 between Carter Spit and Platinum on 25 April 1983, 28 April 1984, 12 May 1985, and 4 May 1986, respectively. D. F. Parmelee and J. M. Parmelee (unpublished) identified six male and two female greater scaup in Chagvan Bay on 27 May 1987. During aerial surveys along the coast, estimates of scaup included 1,042 in 1982 (2 May; R. J. King and C. P. Dau, unpublished), 690 in 1988 (3 May; R. J. King and C. P. Dau, unpublished), and 1,019 in 1989 (4 May; R. J. King and C. P. Dau, unpublished). We saw two pairs each year during summer at the Tuluksak River in two upland lakes and believed they nested there. Birds were also seen during summer at the Kisaralik River on 16 June 1987 (B. J. McCaffery, personal communication), Kagati Lake in July 1962 (M. J. Fry, unpublished), and the Eek River on 17-25 June 1985 (M. Brown et al., unpublished); 25 were molting near Kagati Lake on 3 August 1973 O. L. Hout, personal communication). We suspect that they also nested at Goodnews and Chagvan bays; J. L. Hout (unpublished) found 40-50 scaup in Chagvan Bay on 23-28 July 1969. D. R. Herter and D. Lloyd (personal communication) observed adult scaup with broods in Nanvak Bay on 3 August 1981, and D. R. Herter et al. (personal communication) found birds there on 7-29 June and 18 July 1984 . We found fall migrants at Nanvak Bay on 1 September 1973 and 1 at the Tuluksak River as late as 23 September 1977; J. G. King (unpublished) found 5,000 birds in September 1963 at Chagvan Bay. 


\section{Common eider (Somateria mollissima). Uspm, Csr, Cwr?}

This eider occurred along the coast and on offshore islands. Spring migrants passed Cape Peirce during 2-15 May 1973 and 5 May-9 June 1976 in low numbers ( $25 \pm 15.7$ birds per hour during $8.8 \mathrm{~h}$ in 1976). Birds roosted in ice-free areas or on ice floes in Nanvak Bay in spring. J. G. King and M. A. Monson (unpublished) found several thousand eiders in the open waters of Bristol Bay, Hagemeister Strait, and Togiak Bay during an aerial survey on 22 April 1968; C. P. Dau (unpublished) reported 62 eiders on the coastal portion of the area during an aerial survey on 23 April 1981. We found eiders along the entire coastal portion of the study area in summer. Eiders probably migrated along coastal areas in late fall and wintered there until sea ice formed; 33 birds were at Nanvak Bay on 25 September 1973. Common eiders are common in Bristol Bay in open water during fall and winter (King and Dau 1981).

We saw flightless birds at Nanvak Bay and in inshore waters near Cape Peirce (28 July-9 September 1976) and near Summit and Round islands (9 July 1962). Thirty-three eiders were at Nanvak Bay on 25 September 1973. P. D. Arneson and D. B. McDonald (personal communication) saw eiders at Crooked, High, and Hagemeister islands in June-July 1977.

Birds nested near Chagvan Bay where J. L. Hout (unpublished) found one female with six young in July 1969. Common eiders nested on an island in Nunavachak Lake in July 1962 . Approximately 100 pairs nested at Shaiak Island in 1976. At least 10 eider eggs were among hundreds of gull eggs taken by local people at Shaiak Island on 14 July 1973 . D. R. Herter and D. Lloyd (personal communication) found broods in Nanvak Bay and on Shaiak Island in 1981. Egg laying began in early June in 1973 and 1976 at Shaiak Island. Nests there were subject to severe losses due to red fox predation during some years (Petersen 1982).

King eider (Somateria spectabilis). Aspm, VRsr, Awr.

King eiders were found only in coastal areas. Migration past Cape Peirce was spectacular with 62,800 birds per hour $(2 \mathrm{~h}$ ) passing on 2 May 1973 and 4,600 birds per hour ( $2 \mathrm{~h}$ ) at peak migration on 5 May 1976. In 1976, pairs migrated primarily between 30 April and 17 May, and subadults migrated primarily between 22 May and 30 June (peak, 1 June; 200 birds per hour, $2 \mathrm{~h}$ ). Flocks were reported in ice-free areas along the coast in early spring in inshore and offshore waters (C. P. Dau, unpublished; J. G. King, unpublished; D. I. Eisenhauer, personal communication). A flock of eight birds (both sexes) flew northward over Chagvan Bay on 25 May 1987 (D. F. Parmelee and J. M. Parmelee, unpublished). Subadult (DNW photo, MHD photo) and adult males molted in nearshore and inshore waters throughout the study area between 30 July and 
25 September. King eiders were also found at Cape Peirce on 26-27 June 1970 (H. P. Brokaw, unpublished), 13 June-15 August 1981 (D. R. Herter and D. Lloyd, personal communication), and 5 June-12 July 1984 (D. R. Herter et al., personal communication). P. D. Arneson and D. B. McDonald (personal communication) found eiders at Round (1 bird), Summit ( 8 birds), Crooked (about 50 birds), High ( 25 birds), and Hagemeister (about 150 birds) islands in June-July 1977.

A few king eiders have been found breeding in the area. A pair was flushed from dwarf shrub mat at Cape Peirce on 13 June 1976-the fresh, down-filled nest contained no eggs, suggesting mammalian predation. A female with seven flightless young was at Round Island on 18 July 1974 (T. J. Eley, unpublished). These observations of nesting birds at Cape Peirce and Round Island are far south of their normal breeding range. General nesting distribution for king eiders is far north of our study area with the closest known nesting at St. Matthew Island.

Steller's eider (Polysticta stelleri). Cspm, Afm, FCv, (18 April-8 October). Specimen: YDNWR(MHD-70-24).

Steller's eiders were found only on the coast. We frequently saw birds flying past Cape Peirce and in open leads in Nanvak Bay during spring migration (27 April-10 June 1973 peak, 5 May; 28 April-14 June 1976 peak, 13 May). C. P. Dau (unpublished) reported 340 birds from Platinum to Security Cove during an aerial survey on 23 April 1981. Estimates during additional aerial surveys of the coast included 15,725 in 1983 (25 April; C. P. Dau, unpublished), 1,380 in 1984 (28 April; C. P. Dau, unpublished), 2,749 in 1985 (12 May; C. P. Dau and R. J. King, unpublished), 300 in 1986 (4 May; C. P. Dau and R. J. King, unpublished), 1,419 in 1988 (3 May; R. J. King and C. P. Dau, unpublished), 4,230 in 1987 (1 May; R. J. King and C. P. Dau, unpublished), and 1,384 in 1989 (1 May; R. J. King and C. P. Dau, unpublished). D. I. Eisenhauer (unpublished) found birds in Chagvan Bay on 18 April 1973, and D. F. Parmelee and J. M. Parmelee (unpublished) found 10 birds in the bay and about 100 flying over the bay on 22 May 1987. Fall migration of Steller's eiders past Cape Peirce began on 4 August 1970, 16 August 1973, and 16 August 1976 and continued at least through 25 September 1973 and 2 September 1976. On 5 August 1970, 146 birds per hour ( 2 h) flew past Cape Peirce; peak numbers occurred on 19 August 1976 when 169 birds per hour ( $2 \mathrm{~h}$ ) passed the cape. R. E. Gill and R. King (unpublished) found 505 birds on the coast between Estus Point and Kulukak Bay during an aerial survey on 6 October 1980. Estimates of numbers of Steller's eiders along the coast in fall during aerial surveys included 359 in 1985 (6 October; R. J. King and W. D. Eldridge, unpublished), 670 in 1987 (2 October; R. J. King and W. D. Eldridge, unpublished), 1,152 in 1988 and 798 in 1989 (8 and 7 October, respectively; R. J. King and L. Denlinger, unpublished). 
We found molting (flightless) birds around Cape Peirce (hundreds in August 1970 and from 8 July to 2 September 1976), Nanvak Bay (several hundred on 25 August 1970 and 8 July-13 August 1976), and Chagvan Bay (500 eiders in basic plumage and able to fly on 20-22 July 1974 [DNW photo], 1,300 birds on 17 July 1986, and none on 5 August 1988); all were thought to be males. J. G. King (unpublished) found 200-300 molting birds in Nanvak Bay on 3 September 1963; D. R. Herter and D. Lloyd (personal communication) found eiders at Cape Peirce from 20 June-15 August 1981; D. R. Herter et al. (personal communication) found Steller's eiders at Cape Peirce on eight days from 6 June-12 July 1984. We also found birds at the Walrus Islands ( 2 males on 9 July 1962), and P. D. Arneson and D. B. McDonald (personal communication) found birds at Round (about 10 birds), Summit ( 94 birds), Crooked (about 200 birds), and Hagemeister (about 175 birds) islands in June-July 1977.

Harlequin duck (Histrionicus histrionicus). Av, Asr (27 April25 September). Specimens: RMS1962/36/02, RMS1962/36/03, and RMS1974/119/13.

Harlequins nested throughout the study area and molted along the coast. They nested at the Salmon, Tuluksak, Kisaralik, Kanektok O. L. Hout, personal communication), and Togiak rivers; near Nyac (Mindell 1983); at Kagati Lake (M. J. Fry, unpublished); and at the Goodnews and Smalls rivers (B. Huffmon, personal communication). Harlequins were found in spring at Chagvan Bay on 22 May 1987 when two pairs were swimming in the bay and a mixed flock of six individuals flew southwest over the bay (D. F. Parmelee and J. M. Parmelce, unpublished). In summer, they were seen at Nanvak Bay (400 birds; J. L. Hout, unpublished). Harlequins were also found in summer at the Kisaralik River on 16-21 June 1987 (B. J. McCaffery, personal communication) and on 8-25 August 1985 (M. Brown ct al., unpublished), at the Kwethluk River on 12-19 July 1985 (less than scven birds; M. Brown et al., unpublished), and at the Eck River on 23-26 June 1985 (M. Brown et al., unpublished). Harlequins were observed at offshore islands in summer (Arneson 1977; R. MacIntosh, unpublished; E. H. Miller, unpublished) and molted there and along the coast to Goodnews Bay.

Pairs arrived at the Tuluksak River on 10-20 May (C. Clark, Jr., and $\mathrm{J}$. Birch, personal communication), and males usually left in early June. However, in 1978, when most females did not hatch eggs, males (DNW photo) remained until 26 June or later; at least seven females were seen repeatedly in June and only one brood was found that year. In each of 10 other years on $48 \mathrm{~km}$ of the Tuluksak River and main tributaries, we found 5-10 pairs or single adults, and 2-4 females with broods (DNW photo). Small downies were first seen on 10-15 July, and some flying or nearly flying young were found by 14-22 August. Fifteen broods averaged 
4.2 young per brood (range, 2-7). Late small downies were found at the Kisaralik River above timberline on 26 July 1979 (this study) and Kagati Lake on 10 August 1962 (M. J. Fry, unpublished). A flock of 30 males was on the Kisaralik River on 21 June 1987 (B. J. McCaffery, personal communication).

We found migrating and molting harlequins in rocky intertidal areas and off rocky beaches (Fig. 13) along the coast at Goodnews Bay, Chagvan Bay, Capc Peirce, Shaiak Island, and Walrus Islands. We saw paired and unpaired birds on 27 April 1973 and 28 April 1976 and they remained at Cape Peirce until late May and early June (1970, 1973, and 1976); thereafter, we saw primarily males in prebasic molt and basic plumage. Small flocks of ducks used rocky intertidal areas at Capc Peirce on 26-27 June 1970 (H. P. Brokaw, unpublished). There were flocks of males in Goodnews Bay by 10 June 1974 . We found flightless birds on 14 June-8 September, but most were capable of flight by 25 August 1976.

Oldsquaw (Clangula hyemalis). Aspm, Csr, FCfm (18 April-7 October).

Oldsquaws nested in the Ahklun Mountains and on the coast and used coastal estuaries in spring and fall. Large flocks of oldsquaws were in the open waters of Bristol Bay, Hagemeister Strait, and Togiak Bay during an aerial survey on 22 April 1968 J. G. King and M. A. Monson, unpublished);

Fig. 13. Rocks adjacent to cliffs typically used by loafing harlequins while flightless; Cape Peirce, 21 August 1973. Photo by M. R. Petersen. 
birds were found in Chagvan Bay by 18 April 1973 (D. I. Eisenhauer, personal communication). Oldsquaws migrated past Nanvak Bay and Cape Peirce and courted in the bay during spring migration (28 April-12 June 1973 peak, 2 May; and 28 April-26 May 1976 peak, 3 May). Aerial survey estimates of oldsquaws along the coast in spring included 18 in 1985 (25 April; C. P. Dau, unpublished), 10 in 1987 (1 May; R. J. King and C. P. Dau, unpublished), 100 in 1988 (3 May; R. J. King and C. P. Dau, unpublished), and 591 in 1989 (4 May; R. J. King and C. P. Dau, unpublished).

Oldsquaws were found along the coast at Cape Peirce between 30 May and 18 July $(1970,1973$, and 1976); D. R. Herter et al. (personal communication) and D. R. Herter and D. Lloyd (personal communication) also found oldsquaws at Cape Peirce in summer 1981 and 1984. Oldsquaws were at Crooked and Hagemcister islands in June-July 1977 (P. D. Ameson and D. B. McDonald, personal communication). Oldsquaws nested at Kagati Lake (M. J. Fry, unpublished) and were found along the Kanektok River (White and Boyce 1978; J. L. Hout, personal communication), at the Kisaralik River (16-27 June 1987; B. J. McCaffery, personal communication), and at the Eek River (22 and 25 June 1985; $M$. Brown et al., unpublished). They nested at Chagvan Bay and may have nested near Nanvak Bay at the Slug River. We also found 18 flightless birds in a large lake ncar Nanvak Bay on 27 August 1976. A few fall migrants passed through Nanvak Bay as late as 25 September 1973; 34 oldsquaws were seen during an aerial survey along the coastal study area on 7 October 1989 (R. J. King and L. Denlinger, unpublished).

\section{Black scoter (Melanitta nigra). Aspm, Usr (23 April-8 October).}

This scoter nested near the coast and possibly inland, molted in inshore and nearshore waters, and migrated near the coast. Estimates of black scoters along the coast in spring included 9 in 1981 (23 April; C. P. Dau, unpublished), 0 in 1982 (3 May; C. P. Dau, unpublished), 269 in 1983 (25 April; C. P. Dau, unpublished), 30 in 1984 (28 April; C. P. Dau, unpublished), 125 in 1985 (12 May; C. P. Dau and R. J. King, unpublished), 52 in 1986 (4 May; C. P. Dau and R. J. King, unpublished), 212 in 1987 (1 May; R. J. King and C. P. Dau, unpublished), 642 in 1988 (3 May; R. J. King and C. P. Dau, unpublished), and 2,470 in 1989 (4 May; R. J. King and C. P. Dau, unpublished). Mixed sex flocks of up to 31 birds were scen daily at Cape Peirce from 5 May to 18 June 1973; the sex ratio of those 324 birds was 1.6 males to 1.0 female. Flocks of up to 850 paired black scoters migrated past Cape Peirce between 30 April and 20 June 1976 (peak, 1 May, 820 birds per hour during 2 h). Five male scoters flew northward over Chagvan Bay on 27 May 1987 (D. F. Parmelee and J. M. Parmelee, unpublished). Molt migration of males past Cape Peirce occurred from mid-June to the end of July 1984 and 1985 and peaked both years on 11 July (Herter et al. 1989). We found them throughout summer June-Sep- 
tember) in Goodnews, Chagvan, and Nanvak bays; P. D. Ameson and D. B. McDonald (personal communication) found them near Crooked, High, and Hagemeister islands in June-July 1977. Flightless scoters were in our study area beginning 15 August. Estimates of black scoters during aerial surveys along the coast included 1,208 in 1988 ( 4 October) and 1,518 in 1989 (7 October; R. J. King and L. Denlinger, unpublished).

We found nesting scoters near Nanvak Bay: One nest in tall sedge (Carex sp.) had four of six eggs hatch during 11-15 August 1970, and one young with some down still visible was in the Slug River on 5 September 1973. D. R. Herter and D. Lloyd (personal communication) found 5 females with 25 young in Nanvak Bay on 3 August 1981. Birds were recorded inland at Icebox Lake and the Kisaralik River on 16-17 June 1987 (B. J. McCaffery, personal communication), Kagati Lake in July- August 1962 (M. J. Fry, unpublished), the Kanektok River in June 1977 (White and Boyce 1978), and the lower Eck River on 11 August 1976 (R. Baxter, unpublished).

Surf scoter (Melanitta perspicillata). Cspm, VRst? (23 April25 September).

Surf scoters used coastal areas and possibly nested in the Ahklun Mountains. We frequently saw them during spring and summer migration (21 June-10 August 1970, 1-11 June 1973, and 21 May-13 July 1976). C. P. Dau (unpublished) reported 10 birds between Platinum and Security Cove on 23 April 1981, and D. F. Parmelee and J. M. Parmelee (unpublished) found a flock of about 30 individuals (both sexes) feeding along the coast near Chagvan Bay on 22 May 1987.

Peaks of movement past Cape Peirce were noted on 22 June $1970(98$ birds per hour during 2 h), 30 June 1976 (71 birds per hour during 2 h; this study), and 11 July 1984 and 1985 (Herter et al. 1989). We found molting birds in Chagvan Bay July 1974) and frequently found scoters there near the cliffs and feeding in the surf June-September). Surf scoters were also found near Crooked, High, and Hagemeister islands in June-July 1977 (P. D. Ameson and D. B. McDonald, personal communication). We found flightless scoters at Cape Peirce beginning on 30 July, and flightless birds were still present on 9 September 1976 when we left the area. Scoters possibly nest in the Ahklun Mountains. They were seen at the Eek River on 10 August 1976 (R. Baxter, unpublished) and at Kagati Lake in summer 1962 (M. J. Fry, unpublished).

White-winged scoter (Melanitta fusca). Cspm, Rsr?, Cfm (23 April8 October).

White-winged scoters were common in coastal areas and possibly nested in the Ahklun Mountains. Nineteen birds were between Platinum 
and Security Cove during an aerial survey on 23 April 1981 (C. P. Dau, unpublished), and along the entire coastal area, 2 were seen in 1984 (28 April; C. P. Dau, unpublished), 5 in 1985 (12 May; C. P. Dau and R. J. King, unpublished), 9 in 1988 (3 May; R. J. King and C. P. Dau, unpublished), and 36 in 1989 ( 4 May; R. J. King and C. P. Dau, unpublished). Birds migrated past Cape Peirce during spring 1973 (28 April-4 June, peak, 4 May) and 1976 (30 April-1 June-peak, 12 May) and again in summer June-July) 1970, 1976 (this study), 1984, and 1985 (Herter et al. 1989). Molt migration of scoters peaked on 11 July 1984 and 1985 (Herter et al. 1989) at 1,180 birds per hour in 1984 (Woodman et al. 1985). In summer, scoters migrating past Cape Peirce in 1970-76 were predominantly male (79-91\%) and most were white-winged (85\%), as were scoters migrating in 1984-85 (88-94\% males and 91-98\% white-winged scoters; Herter et al. 1989). At Cape Pcirce in fall 1973, small mixed flocks were in inshore waters from 15 August to 14 September, and only males were present thereafter through 25 September. During aerial survcys of waterbirds from Jacksmith Bay to Cape Peirce, 1 and 53 scoters were observed on 8 October 1988 and 7 October 1989, respectively (R. J. King and L. Denlinger).

White-winged scoters were at Walrus Islands during 8-17 June 1972 (E. H. Miller, unpublished) and near Crooked, High, and Hagemeister islands in June-July 1977 (P. D. Arneson and D. B. McDonald, personal communication). We found molting (flightless) birds in inshore waters off Cape Peirce (20 July-8 September 1976), still-flying birds off the Walrus Islands on 9 July 1962, and flying birds from Goodnews Bay to Chagvan Bay on 18-20 July 1974. White-winged scoters were abundant at Kagati Lake in July-August 1962 (M. J. Fry, unpublished) and seen at the Eek River on 25-26 June 1985 (M. Brown et al., unpublished).

Common goldeneye (Bucephala clangula). FCspm, Csr, Ufm (21 April-7 October). Specimen: RMS1962/36/01.

Goldeneyes nested in the Kilbuck and Ahklun mountains and migrated along the coast in spring and fall. In spring 1973, D. I. Eisenhauer (personal communication) found 2 females and 1 male in Chagvan Bay on 21 April, and we found up to 18 birds daily in Nanvak Bay in 1973 (28 April-10 Junc) and 1976 (30 April-14 May). Estimates of goldencyes during aerial surveys along the coast in spring included 120 birds in 1983 (25 April; C. P. Dau, unpublished), 20 in 1986 (4 May; C. P. Dau and R. J. King, unpublished), 49 in 1987 (1 May; R. J. King and C. P. Dau, unpublished), and 52 in 1989 (4 May; R. J. King and C. P. Dau, unpublished). In fall, 30 birds were observed on 7 October 1989 (R. J. King and L. Denlinger, unpublished).

During the nesting season, White and Boyce (1978) found birds in lakes along the Kanektok River, B. J. McCaffery (personal communication) 
found them along the Kisaralik River on 19-21 June 1987, and M. Brown et al. (unpublished) found one bird at the Eek River on 26 June 1985. Birds nested at the Tuluksak River (DNW photo) and Togiak Lake, and possibly nested at the Salmon River. Nests at the Tuluksak River were in timbered areas near rivers, ponds, and sloughs at $120 \mathrm{~m}$ asl. Residents called goldeneyes "stovepipe ducks" because they investigated chimneys and abandoned dredge boiler stacks for possible nest sites. They also nested in balsam poplar stumps. At the Tuluksak River ( $48 \mathrm{~km}$ of stream), we found an average of 5.0 pairs per year and 3.0 broods per year until 1981 . During those years, four broods of small downies averaged 5.8 young (range, 3-7), and four broods of fledged young averaged 6.5 young (range, 4-9). Eggs in one nest hatched on 20 June 1974. There, broods of small downies were first seen on 22-26 June, and newly fledged young were first seen on 5-10 August. In 1983, after the 1982 showshoe hare (Lepus americanus) population crash, red foxes were seen hunting and killing young goldeneyes. In that year, 5 broods of newly hatched ducklings averaged 9.6 young (range, 7-12), and 5 broods of large downy-to-feathered ducklings averaged 2.5 young (range, 1-4). At the Tuluksak River in 1986 , three broods of small ducklings averaged 6.0 young (range, 4-8), and two broods of larger ducklings averaged 5.5 young (range, $4-7)$. Three broods of larger ducklings averaged 3.0 young $(2,3$, and 4 young) in 1987. A female and three small downy young were at Togiak Lake on 3 August 1973.

Barrow's goldeneye (Bucephala islandica). VRv.

Three adult male Barrow's goldeneyes were seen in Nanvak Bay on 4 June 1969.

Bufflehead (Bucephala albeola). Rspm, Rsr.

Buffleheads nested in the Ahklun Mountains and possibly in the Kilbuck Mountains and used estuaries on the coast in spring. Two to 10 birds were seen on 6 and 15 June 1973 and on 5 of 19 days between 12 and 30 May 1976 in Nanvak Bay during spring migration. We found a dead female at the Salmon River in July 1974. A pair was reported at the Tuluksak River in late May-early June 1961 (C. Clark, Sr., personal communication). We saw three females on the Togiak River on 7 August 1973. A brood of three young was on the Kanektok River on 5 August 1973 J. L. Hout, personal communication).

Common merganser (Mergus merganser). Rsr.

Birds nested in the Kilbuck and Ahklun mountains. We found nesting birds at the Salmon, the Tuluksak, and the Kisaralik rivers in most years, and M. J. Fry (unpublished) found breeding birds at the Kagati Lake. Birds 
were seen in summer at the Kisaralik River (M. Brown et al., unpublished), the Kwethluk River (M. Brown et al., unpublished), the Eek River (R. Baxter, unpublished; M. Brown et al., unpublished), the Kanektok River, and the Kinegnak River. Two common mergansers were seen during an acrial survey from Carter Spit to Platinum on 12 May 1985 (C. P. Dau and R. J. King, unpublished).

We found broods or pairs in streams $\geq 10 \mathrm{~m}$ wide in riparian woodlands at the Salmon, the Tuluksak, and the Kisaralik rivers. We found $1.5 \pm 0.5$ pairs of birds per year $(N=8$ years) in 12 seasons at the Tuluksak River along $48 \mathrm{~km}$ of streams. Downies were found on 11 July 1976,9 July 1983 , and 21 July 1987, and fully feathered young were seen on 26 July 1979 and 23 August 1977.

Red-breasted merganser (Mergus serrator). Uspm, Csr, Ufm (28 April- 8 October).

This merganser nested throughout the study arca and used estuaries during migration and when molting. Birds nested at the Salmon River, the Tuluksak River, the Kisaralik River, the Togiak River (this study), Kagati Lake (M. J. Fry, unpublished), the Kancktok River (White and Boyce 1978; J. L. Hout, personal communication), Togiak Lake, Goodnews Bay, Chagvan Bay, and Nanvak Bay. Mergansers were also seen by others at the Kisaralik River (10 and 14 August 1985; M. Brown et al., unpublished), at the Kwethluk River (10-26 July 1985; M. Brown et al., unpublished), and at the Eek River (17-29 June 1985; M. Brown et al., unpublished). Mergansers molted at Goodnews, Chagvan, and Nanvak bays and Cape Peirce, and they migrated past Cape Peirce and Nanvak Bay. D. F. Parmelee and J. M. Parmelee (unpublished) observed a pair on 23 May 1987 and a probable breeding pair during 25-26 May near Chagvan Bay. P. D. Arneson and D. B. McDonald (personal communication) found birds at Crooked and Hagemeister islands in June-July 1977.

From 1 to 17 birds were seen each day throughout spring migration (28 April-17 June) in Nanvak Bay or in inshore waters at Cape Pcirce. During spring aerial surveys along the coast, estimates of mergansers included 30 in 1983 (25 April; C. P. Dau, unpublished), 2 in 1984 (28 April; C. P. Dau, unpublished), 2 in 1985 (12 May; C. P. Dau and R. J. King, unpublished), 4 in 1986 (4 May; C. P. Dau and R. J. King, unpublished), 154 in 1987 ( 1 May; R. J. King and C. P. Dau, unpublished), 354 in 1988 (3 May; R. J. King and C. P. Dau, unpublished), and 795 in 1989 (4 May; R. J. King and C. P. Dau, unpublished). In summer, we found up to 300 birds (both sexes) each year at Nanvak Bay and flightless birds in the bay and in inshore waters from 30 July to 7 Scptcmber; J. G. King (unpublished) found approximately 300 birds at Nanvak Bay on 3 July $1964, D$. R. Herter and D. Lloyd (personal communication) found up to 150 birds there in July 1981, and D. R. Herter et al. (personal communication) found 375 
birds there on 7 July 1984 . J. L. Hout (personal communication) found 10-20 birds in Chagvan Bay on 23-28 July 1969. R. J. King and L. Denlinger (unpublished) found 20 birds on 8 October 1988 and 7 October 1989 during aerial surveys along the coast.

We found red-breasted merganser broods in streams $\geq 5 \mathrm{~m}$ wide and in lakes from sea level to about $400 \mathrm{~m}$ asl. Up to 10 adults and from 2 to 5 broods (DNW photo; $7.2 \pm 1.14$ pairs or broods per year) were seen at the Tuluksak River ( $48 \mathrm{~km}$ of streams) in 8 of 10 years; in 1986 we found no broods. From the air at the Kisaralik River, we saw no broods in 1977, 1 in 1978, and 20 in 1979. During a float trip on the Kisaralik River in July 1979 , about 100 birds per day were seen, with flocks of up to 40 birds. Pairs and singles were seen most days during a float trip on the Kisaralik River on 16-21 June 1987 (B. J. McCaffery, personal communication). During a float trip on the Salmon River in August 1979 about 200 birds per day were seen (maximum about 500 birds per day), with flocks of up to 60 birds. Broods of 8 and 15 ducklings were seen from 4 to 6 August 1973 during a float trip on the Togiak River. In inland areas, 12 broods averaged 7.5 young (range, 1-15). At the Tuluksak River, small downies were found on 28 June 1974, broods fledged beginning 11 August 1977 and 22 August 1974, and no birds were seen after 20 September. We found downy young in Nanvak Bay on 15 August -5 September, and D. R. Herter and D. Lloyd (personal communication) found 1 female with 14 downy young on 17 July 1981 at Cape Peirce.

Osprey (Pandion haliaetus). VRsr.

We recorded single ospreys on three occasions in spring-at Cape Peirce on 20 May 1976 and 5 June 1970 and at Slug Mountain (Cape Peirce) on 10 June 1973. Ospreys may have nested at the upper Salmon River in 1974 and did nest downstream of our study area on the lower Salmon and Aniak rivers in 1979 and 1986. They also nested at the Kanektok River in 1962. One was seen at the Tuluskak River in August 1952 and one adult was seen on the lower Kisaralik River on 30 July 1979.

Bald eagle (Haliaeetus leucocephalus). Usr, Ufm (23 April-15 Octo ber).

Bald eagles nested throughout the study area and migrated through the Kilbuck Mountains. Eagles nested at the Salmon River (DNW photo), the Kisaralik River (this study, B. J. McCaffery and R. D. Ernest, unpublished), the Kanektok River (White and Boyce 1978; J. L. Hout, personal communication), Goodnews Lake, the Goodnews River (this study), Cape Newenham J. L. Hout, personal communication), Cape Peirce (MHD photo; MRP photo; D. R. Herter and D. LJoyd, personal communication), Round Island (E. H. Miller, unpublished), and Crooked Island 
(P. D. Arneson and D. B. McDonald, personal communication). Bald eagles were "suspected" to nest at Summit and High islands (P. D. Arneson and D. B. McDonald, personal communication), and were seen in summer at the Kwethluk River (M. Brown et al., unpublished), Kagati Lake (M. J. Fry, unpublished), and the Togiak River. An empty nest with an eagle nearby was along the Eek Rjver (White and Boyce 1978), and birds were seen there on 24 and 27 June 1985 (M. Brown et al., unpublished).

Of 10-12 nesting locations visited systematically on this area, $>50 \%$ appeared occupied by pairs, but visits to some sites in only 1 year exaggerated occupation. Of the 21 eagles seen in summer near nest sites, excluding juveniles, $15(71 \%)$ were adults and $6(28 \%)$ were unpaired subadults. Inland nest sites were below timberline in riparian woodlands in broad valleys (30-215 $\mathrm{m}$ asl) close to beaver (Castor canadensis) ponds or lakes (seven nests) or in spruce woodland in a narrow valley beside an extensive beaver dam complex (one nest). Sites on the coast (two) were near large seabird colonies. Nests were on steep areas of sea cliffs (two), the tops of balsam poplars (two), the top of a paper birch (onc), the tops of white spruces (two), and the tops of unspecified broadleaf trees (thrce).

Pairs were present at Cape Peirce in late April in 1973 and 1976, and birds were seen in the area during an acrial survey on 23 April 1981 (C. P. Dau, unpublished). An adult was incubating eggs there on 5 May 1973, and small, downy young were found on 6 July 1970. The young at Cape Peirce had not fledged by 20 August 1970, fledged between 2 and 4 July 1981 (D. R. Herter and D. Lloyd, personal communication), and by 12 August 1976. Large, downy young were found inland on 20 July 1978. A nest with two eaglets was located at the Kisaralik River on 5 July 1988 (B. J. McCaffery and R. D. Ernest, unpublished). Adults and immatures were on Round Island on 11-12 June 1972 (R. H. Miller, unpublished). Broods along the coast consisted of two young (three broods) and one young (threc broods). At the upper Tuluksak River migrants were found primarily in early October and an adult was seen on 15 October 1977.

Food items from the nest at Cape Peirce included salmon (Oncorhynchus spp.), wolffishes (Anarhichadidac), kittiwakes (Rissa spp.), and tufted puffins (Fratercula cirrhata). During the snowshoe hare population crash at the Tuluksak River in 1982, at least six bald cagles (mainly subadults or immatures) were present from spring to late fall and fed on dead or dying hares (J. Birch, personal communication). Prey remains beneath two nests near our study area at the Kuskokwim River included one Barrow's goldeneye, one mallard, four unidentified ducks, one Canada goose, one showshoe hare, one sheefish (Stenodus leucichthys nelma), and four unidentificd fish (Mindell 1983). 
Northern harrier (Circus cyaneus). Rspm, Usr, Ufm (29 April25 September).

Northern harriers were seen almost daily at Cape Peirce during spring migration (29 April-14 May) in 1976, and only once in 1973 (6 June), but not at all in 1970. D. F. Parmelee and J. M. Parmelee (unpublished) saw a single male near Chagvan Bay on 25 May 1987. Harriers nested at the Salmon and Tuluksak rivers, and pairs were found at the Kisaralik River, llanik Lakes, and the Togiak River during summer and fall. A pair was at Icebox Lake near the Kisaralik River on 16-17 June, and birds were at the Kisaralik River on 17-20 June 1987 (B. J. McCaffery, personal communication) and 12 and 19 August 1985 (M. Brown et al., unpublished). Birds were also seen at the Eek River (R. Baxter, unpublished; M. Brown et al., unpublished), the Kwethluk River (M. Brown et al., unpublished), and Kagati Lake (M. J. Fry, unpublished) during summer.

At the Tuluksak River, one to four pairs $(2.3 \pm 0.5$ pairs per year) were found in each of 10 years along $48 \mathrm{~km}$ of major streams. Nesting areas were all in dwarf shrub meadows with low and medium shrub thickets of willow in more or less broad valleys at 90-300 $\mathrm{m}$ asl. Fledged young were still near nests on 8 and 18 August, and all harriers were gone from nesting areas by 25 August 1974 and 31 August 1977. Birds migrated past Cape Peirce in fall during some years (12 sightings, 27 August25 September 1973; 10 sightings, 14 August -6 Scptember 1976).

Sharp-shinned hawk (Accipiter striatus). VRv.

Weir saw an adult female on the Salmon River on 27 July 1986 in riparian habitat with spruce and cottonwood (Populus spp.).

Northern goshawk (Accipiter gentilis). Csr, Rfm, Uwr. Specimen: RMS1962/36/05.

Goshawks wintered at the Tuluksak River (C. Clark, Jr., and J. Bloomquist, personal communication), nested in the northern Kilbuck Mountains at the Salmon, the Tuluksak (DNW photo) and the Kisaralik rivers, and migrated along the coast near Cape Peirce.

Five nesting territories at the Tuluksak River that we visited annually had $2.8 \pm 0.6$ pairs per year during 8 years. All territories were in tall riparian spruce-cottonwood woodlands (122-305 $\mathrm{m}$ asl), and the centers of the territories were $4.2-4.4 \mathrm{~km}$ apart. Nine nests were at the forks of main branches and trunks in balsam poplars 6-20 m tall, generally between half and three-quarters up the tree. One bird was incubating on 20 May 1974, one nest had newly hatched young on 12 June 1974, and seven pairs had young flying between $3-25$ July in all years. Young were still present and being fed by adults until 18 September 1977, but some 
were independent beginning on 21 August 1977 and 26 August 1974 . Nine broods averaged 2.8 young (range, 2-4). One nest with eggs was deserted after logging activitics began ncarby, and another lost young by predation, possibly by a lynx (Iynx canadensis). No goshawks were scen on the Tuluksak River in June-July 1983 following the sharp decline in the snowshoe hare population in 1982. Goshawks were nesting again in 1986 (C. Clark, Jr., personal communication).

Adult goshawks at the Tuluksak River had typical $A$. g. atricapillus markings on their head and underparts, except for a breeding female in 1979 that was strongly leucistic. Leucism seems not to have been previously recorded in $A . g$. atricapillus but is common in the east Siberian A. g. albidus (Brown and Amadon 1968).

Sixty-three food items were found at nests on the Tuluksak River: 12 varied thrushes (Ixoreus naevius), 10 ptarmigans (Lagopus spp.), 10 unidentified small passerines, 8 snowshoe hares, 5 arctic ground squirrels (Spermophilus parryii), 5 gray jays (Perisoreus canadensis), 4 spruce grouse (Dendragapus canadensis), 4 American robins (Turdus migratorius) and thrushes (Catharus spp.), 1 red squirrel (Tamiasciurus hudsonicus), 1 northern pintail, 2 goldeneyes, and 1 fox sparrow (Passerella iliaca).

Fall migrants were seen at Cape Peirce in 1970 ( 7 August) and 1976 (28-30 August, 6-7 September). At the Tuluksak River juveniles were seen until 15 October and adult goshawks were present in winter.

Swainson's hawk (Buteo swainsoni). VRv.

Three birds were secn at Cape Peirce in 1973-one light phase on 4 May, onc dark phase on $6 \mathrm{May}$, and one dark phase on 13 May.

Red-tailed hawk (Buteo jamaicensis). VRsr.

Red-tailed hawks nested at the Tuluksak River in the late 1950's and early 1960 's (C. Clark, Jr., personal communication), but we saw none there. We found an adult $B$. $j$. harlani type and a juvenile on the lower Salmon River on 9 August 1979. D. A. Boyce and S. J. Fristensky (unpublished) reported two red-tailed hawks in July 1984 on the lower Kisaralik River just outside our area.

Rough-legged hawk (Buteo lagopus). Csr, Rfm (30 April-10 October).

Rough-legged hawks commonly nested along the coastal portion of the study area and locally inland. We saw birds in some years at the Salmon and Tuluksak rivers, and they nested each year at the Kisaralik River. Breeding or probably breeding birds were also found at the Eck River (R. Baxter, unpublished). Rough-legged hawks were seen at Kagati 
Lake (M. J. Fry, unpublished; J. L. Hout, personal communication) and the Kanektok River (White and Boyce 1978).

Nests at 16 locations were on sea cliffs (3), coastal hillside rock outcrops (2), an old dredge near the coast (1), and inland riparian banks, cliffs, or canyons (10). One nest was in riparian spruce-cottonwood, and all others were at higher elevations or north of timberline, $<2.5 \mathrm{~km}$ from coastal or upland valley tundra plains.

Our numbers of rough-legged hawks were as follows: the Tuluksak River, one to four birds in 5 of 10 years along $48 \mathrm{~km}$ of streams (one active nest found 1 year); the Kisaralik River, four nests in 1977, two nests in 1978, and four nests in 1979 along $80 \mathrm{~km}$ of river; and the Kanektok River, one pair each in 1973 and 1977 along $70 \mathrm{~km}$ of river. The following individual rough-legged hawks were also found along the Kisaralik River: two nests with three young each and one nest with four eggs in 1977 (White and Boyce 1978); one family group with two and three family groups with three fledged young each in July 1984 (D. A. Boyce and S. J. Fristensky, unpublished); and active nests with zero, two, and four young on 16-21 June 1987 and one with two young in 1988 (B. J. McCaffery and R. D. Ernest, unpublished). Numbers were greater on the lower Arolik and Goodnews rivers (D. Roseneau, personal communication). Three nests were spaced $6 \mathrm{~km}$ and $21 \mathrm{~km}$ apart along the coast between Goodnews and Chagvan bays in 1974. At Cape Peirce, two nests or pairs were found $5 \mathrm{~km}$ apart in the years 1970,1973,1976, and 1981, and one nest was found there in 1984 by D. R. Herter et al. (personal communication). One pair was found at Cape Newenham.

Of the nests we checked on the entire study area, 10 had 1 to 3 eggs each and fledged 1 to 3 young each. Nests containing eggs and small or newly hatched young were found on 14-21 June (1978) and 20 August (1973; MHD photo). One nest at Cape Peirce had two chicks and one egg on 14 June and the other had five large young on 17 July 1981 (D. R. Herter and D. Lloyd, personal communication).

Four of the 15 pairs for which we noted plumage were black phased, 2 pairs were cross phased (Big Bcluga), and 9 pairs were light phased.

\section{Golden eagle (Aquila chrysaetos). $\mathrm{Cpr}$, $\mathrm{Rfm}$.}

Golden eagles nested in most river systems and were found throughout the area. Eagles nested at the Salmon, Tuluksak (Mindell 1983; DNW photo), Fog (White and Boyce 1978), Kisaralik (White and Boyce 1978; DNW photo; B. J. McCaffery and R. D. Ernst, unpublished; D. A. Boyce, Jr., and S. J. Fristensky, personal communication), Kewthluk (White and Boyce 1978), Eek (White and Boyce 1978; R. Baxter, unpublished), Kanektok (White and Boyce 1978), Arolik (D. Roseneau, personal communication), and Goodnews (D. Roseneau, personal communication) rivers. Birds were seen in summer at Kagati Lake (M. J. Fry, unpublished) 
and Goodnews and Chagvan bays. Fagles were also found in summer at Cape Peirce during 6 June- 6 July 1970 (five observations, plus two observations 25-29 June 1970 by H. P. Brokaw, unpublished); on 27 Junc 1973 (one observation); on 14 June 1981 (one observation; D. R. Herter and D. Lloyd, personal communication); and on 5 July 1984 (one observation; D. R. Ierter et al., personal communication). Eagles seen along the coast in fall include one on 29 September $1971 \mathrm{O}$. L. Hout, personal communication), four observations at Cape Peirce from 25 August to 20 September 1973, and one at Nanvak Bay on 6 October 1981 (R. E. Gill and R. King, unpublished). Birds wintered at the Salmon and Tuluksak rivers (C. Awe, J. Bloomquist, and C. Clark, Sr., personal communication).

We found 62 nests, which were either on riparian banks, cliffs, or canyons (37), hillside rock outcrops (19), or old dredges (2); in spruce trees on or near riparian cliffs (2); or on the ground among boulders (2). Most nests (60\%) were above or north of timberline, but rarely above the limit of subalpine scrub. Nest altitudes were $60-680 \mathrm{~m}$ asl with a mean of about $300 \mathrm{~m}$ asl. Adults foraged in June-Scptember at edges of subalpine scrub, alpine tundra slopes, and rarely in open areas below timberline. At the Tuluksak River, subadults in summer and adults in winter foraged at the edges of woodland-shrub habitats in valley floors and dwarf shrub mat.

On the Tuluksak and Kisaralik rivers, 32-35 pairs of adults, 2 pairs of subadult females and adult males, 4 unpaired adults, and 4 unpaired subadults or immatures were present over 10 ycars of thorough surveys. Annual occupancy of 16 golden cagle territorics at the Tuluksak and Kisaralik rivers was greater than $90 \%$. At the Kisaralik River, an average of $57 \%$ of five eagle territories surveyed over 7 years were occupied by nesting birds each year (B. J. McCaffery and R. D. Ernst, unpublished). We found four territories along $48 \mathrm{~km}$ of streams at the Tuluksak River, and the centers of adjacent territories were $5.6-9.6 \mathrm{~km}$ apart. At the Kisaralik River, the centers between 12 adjacent territorics averaged $6.2 \mathrm{~km}$ apart (range, $4.8-9.0 \mathrm{~km}$ ). Elcven broods of small young averaged 1.7 young (range, 1-3). Of 34 pairs of eagles on the Tuluksak and Kisaralik rivers, 15 ( $44.1 \%$ ) fledged $1.7 \pm 0.2$ young per pair (range, $1-3$ ). All young were reared in the 5 years of highest hare density, including 2.4 young per pair in the peak year, 1981. Ten nest failures included pairs that failed because subadult females did not lay eggs (2), adult females did not lay after a hare population crash (2), eggs failed to hatch probably due to disturbance by humans (4), predation of young (probably a wolverine, [Gulo gulo]) (1), and young taken by humans (1). Three pairs had eggs hatch from 14 to $23 \mathrm{May}$, and young fledged from 8 July to 10 August (11 nests, median date of 23 July). Two young were still in their nest on 24 July 1984 on the Kisaralik River (D. A. Boyce, Jr., and S. J. Fristensky, unpublished), as were young in four nests with two (two nests) and one 
(two nests) each on 16-21 June 1987 (B. J. McCaffery, personal communication). White and Boyce (1978) found one nest with one egg on the Kisaralik River and seven nests containing young. These seven nests included one nest with two young on the Fog River, five nests with two young each and one nest with one young on the Kisaralik River, one nest with one young on the Eek River, and one nest with three young on the Kancktok River.

We found 96 food items in June-September at the Tuluksak River nests: 44 arctic ground squirrels, 36 hares, 7 ptarmigans, 4 spruce grouse, 2 grouse or ptarmigan chicks, 2 small rodents, and 1 hoary marmot (Marmota caligata). Prey remains from two nests at the Tuluksak River in 1980 contained 23 hares, 4 red squirrels, and 3 spruce grouse (Mindell 1983).

American kestrel (Falco sparverius). VRv, VRsr.

M. J. Fry (unpublished) reported a single kestrel at Kagati Lake on 20 August 1962; J. L. Hout (unpublished) found and released a male that had been struck by a truck at Goodncws Mining Camp on 14 September 1971, and we saw a male at Cape Peirce on 27 August 1976 and an adult on the Tuluksak River in July 1986. Kestrels nested at the Tuluksak River in the 1950's and 1960's and in 1982 (C. Clark, Jr., and J. Birch, personal communication); in spring 1982 several birds were secn, and a male that was trapped inside a gold dredge was handled and released by J. Birch (personal communication). At the Tuluksak River, we found $0.5 \pm 0.3$ pairs per year ( $N=10$ years). American kestrels do not generally occur in our area (Gabrielson and Lincoln 1959).

\section{Merlin (Falco columbarius). Usr (5 May-25 August).}

Merlins nested only in the Kilbuck Mountains at the Tuluksak (DNW photo) and Kisaralik rivers and probably at the Salmon River. M. J. Fry (unpublished) found adult pairs at Kagati Lake in the Ahklun Mountains. White and Boyce (1978) found one adult male and one adult female along the Kisaralik River in 1977, and B. J. McCaffery and R. D. Ernst (unpublished) reported a merlin nest they found on 20 June 1987 with at least three young in an abandoned black-billed magpie (Pica pica) nest. Merlin were also seen at the Kisaralik River on 11 (one bird), 15 (two birds), and 23 (one bird) August 1985 (M. Brown et al., unpublished) and the Eek River on 21 June 1985 (one bird; M. Brown et al., unpublished).

Nesting territories in the Kilbuck Mountains were $300-330 \mathrm{~m}$ asl on lower, south-facing slopes of steep hills. Seven territories were at the upper, scrubby edge of birches, and two territories were in lower parts of subalpine willow-alder shrub habitats (used only in the very warm summer of 1977). The nest found by B. J. McCaffery and R. D. Ernest 
(unpublished) was in a poplar grove. Two nests were in the hollow in the middle of the base of multistemmed birches about $4 \mathrm{~m}$ tall.

At the Salmon River, the Kisaralik River, and Kagati Lake, nesting or probably nesting merlins were found at one or two locations in each arca. Merlins were more common along the Tuluksak River than other adjacent river valleys. This increased density of merlins along the Tuluksak River could be attributed to higher densities of important prey items (passerincs) as a result of vegetation changes associated with 70 years of gold mining activities. In $\mathbf{4 8} \mathrm{km}$ of major streams at the Tuluksak River, pairs occupied at least nine territories the centers of which were regularly spaced at $2.2-3.3 \mathrm{~km}$ intervals $(x=2.6)$. Usually five to seven pairs were present each year, and successful pairs fledged 3.2 young per pair $(N=5$; range, 3-4). In each of 4 years with complete censuses, five pairs fledged young each year at the Tuluksak River. Eggs hatched in one nest on 25 May 1974. Six pairs fledged young from 5 to 25 July (1974, 1976-78, 1983 , and 1986). At the Salmon River, an adult female scolded DNW on 27 July 1986. Usually, all birds were gone from the area by 20-25 August.

Food items at nests at the Tuluksak River included one American robin, one Swainson's thrush (Catharus ustulatus), and one savannah sparrow (Passerculus sanduichensis).

\section{Peregrine falcon (Falco peregrinus). VRsr?}

We saw falcons each year at Cape Peirce: 21-25 August 1970 (four observations of single adults, one pair, one immature), 8 May and 7 June 1973, and 20 May 1976 (one female). J. L. Hout (unpublished) saw one bird at Cape Peirce in April 1971 and D. R. Herter et al. (personal communication) saw one there on 20 June 1984 . We found a calling adult at a cliff at the Kisaralik River on 27 July 1979 , but none were seen there by us or others in 7 other years (B. J. McCaffery and R. D. Ernst, unpublished). We saw an adult at an old nest site on a cliff at the Tuluksak River on 26 June 1962 but in no other years. Percgrines nested on the Salmon River in the 1950's to 1960's J. Bloomquist, personal communication), but we saw none there.

\section{Gyrfalcon (Falco rusticolus). Cpr.}

Gyrfalcons maintained territorics throughout the study area. We found nests or pairs in the following areas: one to four pairs in 4 years along $40 \mathrm{~km}$ of river at the Salmon River (DNW photo); one pair or single adult in 8 of 10 years (fledged a total of 9 or 10 young) along $48 \mathrm{~km}$ of streams at the Tuluksak River (DNW photo); four to five pairs each of 3 years along $80 \mathrm{~km}$ of river at the Kisaralik River (DNW photo); and one pair in 1974 from Goodnews to Chagvan bays. Three nests and two birds were seen along the Kisaralik River in 1977 (White and Boyce 1978), four 
nests and a territorial adult were found there in 1982 (Mindell 1983), and one nest was found there in 1987 and 1988 (B. J. McCaffery and R. D. Emest, unpublished). White and Boyce (1978) found one pair in $20 \mathrm{~km}$ of the Fog River in 1977 and thought gyrfalcons nested there and at the Eek River. M. J. Fry (unpublished) saw birds in summer at Kagati Lake. Bull (in Bent 1938) found birds nesting at 14 sites over several years near Goodnews Bay in an area of unspecified size, and D. Roseneau (personal communication) found 6 active nests near Goodncws Bay. We found an active nest near the Arolik River in 1974 and 1980. J. G. King (unpublished) found one gyrfalcon at Cape Peirce on 6 July 1964. We saw a pair there each year in 1973 and 1976. Gyrfalcons were also seen there on 5 June and 16 July 1984 (D. R. Herter et al., personal communication). A few birds migrated past Cape Peirce in spring 1973 (single birds on 3 days between 30 April and 10 May) and many passed through in fall 1973 (1-4 birds per day on 22 days between 18 August and 24 September, and several were seen by D. R. Herter and D. Lloyd (personal communication) in fall 1981. We saw a family group of three near Security Cove on 23 September 1973.

Gyrfalcons foraged mainly at edges of subalpine shrub and dwarf shrub mat. Thirty nests were found on sea cliffs (5), near the coast on a riparian cliff (1), inland on riparian banks, cliffs, and canyons (13), and inland on hillside rock outcrops (11) above or north of timberline $45-565 \mathrm{~m}$ asl and possibly to $630 \mathrm{~m}$ asl. More than $80 \%$ of the gyrfalcon nests were in old stick nests built by other raptors or common ravens (Corvus corax). Spacing between nests at the Kisaralik River averaged $10.0 \mathrm{~km}$ (range, $4.3-14.7 \mathrm{~km}$ ) in 1982 (Mindell 1983).

Clutches collected from the Goodnews area by Bull (in Bent 1938) in 1932-34 averaged 3.5 eggs per nest $(N=8$; range, 2-4). Eight pairs fledged 2.6 young per pair (range, 2-3) near the Tuluksak and Kisaralik rivers. Brood sizes averaged 2.9 young per nest ( $N=13$ nests) on our study area and adjacent areas (Mindell 1983), and nests along the Kisaralik River contained 2, 2, and 3 young in 1977 (White and Boyce 1978) and 4 young on 16 June 1987 (B. J. McCaffery, personal communication). Broken eggs were found in one nest in 1962 (Tuluksak River), and local hunters destroyed the eggs in one nest (Goodnews area). In 1934, Bull (in Bent 1938) found full clutches at Goodnews as early as 22 April. One pair at the Tuluksak River had eggs hatch on 28 May and young fledge on 14 July 1974. Young from three nests at the Tuluksak River fledged each season-about 9 July 1962,16 July 1978 and 22 July 1987 . Three broods at the Kisaralik River fledged from 4 to 19 July 1978 .

Food items from gyrfalcon nests at the Tuluksak and Kisaralik rivers included 20 ptarmigans, 13 arctic ground squirrels, 2 ducks (including 1 green-winged teal), 2 American robins, 1 snowshoe hare, 1 spruce grouse, 1 surfbird (Aphriza virgata), and 1 belted kingfisher (Ceryle 
alcyon). Bull (in Bent 1938) reported that near Goodnews Bay, gyrfalcons ate "the willow ptarmigan and the rock ptarmigan, as well as lemmings, snowshoe rabbits, minks, and weasels."

\section{Spruce grouse (Dendragapus canadensis). Upr.}

Grouse occurred in and near spruce forests throughout the study area. We found them nesting at the Salmon and Tuluksak rivers and the upper Togiak River, and they were reported at the Kisaralik River (C. Clark, Jr., personal communication). Grouse nested in spruce forests, in riparian spruce-cottonwoods, and at the edges of secondary broadleaf woodlands. In August-September, grouse families used dry spruce forests, dwarf shrub mat, and secondary broadleaf woodland; in late October-November, they used spruce forests mainly at the riparian sprucepoplar edges. One to six broods were seen each of 10 years at the Tuluksak River. Broods of large young averaged 4.0 young $(N=8$; range, 3-6); we usually found full-grown young by 1-18 Scptember.

\section{Willow ptarmigan (Lagopus lagopus). FCpr.}

This ptarmigan occurred throughout the study area, with the possible exception of the smaller offshore islands. We found breeding birds at the Salmon River, the Tuluksak River, the Kisaralik River, Goodnews Bay, Chagvan Bay, Cape Pcirce, and Togiak Lake; we also saw birds at the Kwethluk River. Ptarmigans were seen in summer at the Kisaralik River on 16-17 June 1987 (B. J. McCaffery, personal communication) and 10-22 August 1985 (M. Brown et al., unpublished); at the Kwethluk River on 12 and 27 July 1985 (M. Brown et al., unpublished); the Eek River (R. Baxter, unpublished) and 21 and 24 June 1985 (M. Brown et al., unpublished); and the Kancktok River (White and Boyce 1978; J. L. Hout, personal communication). J. L. Hout (personal communication) found a female and seven young at Kagati Lake on 3 August 1973, and M. J. Fry (unpublished) saw birds there in summer. D. Roseneau (personal communication) and $B$. Huffmon (personal communication) found breeding birds at the Arolik and Goodnews rivers; D. F. Parmelee and J. M. Parmelee (unpublished) found probable breeding birds at Chagvan Bay. P. D. Arneson and D. B. McDonald (personal communication) found birds at Crooked Island in June-July 1977. Residents of Nyac reported flocks of ptarmigans in sheltered areas during winter at the upper Tuluksak River.

Ptarmigans were generally in low to tall scrub thickets or dwarf shrub mat habitats at 6-370 $\mathrm{m}$ asl in summer and fall. On 7 May 1973, we found three pairs and nine single birds along a $3.2-\mathrm{km}$ stretch of a stream valley south of Slug Mountain (Cape Pcirce). Flight displays and territorial skirmishes were noted daily beginning 22 May 1987 at Chagvan Bay (D. F. Parmelee and J. M. Parmelec, unpublished). One clutch was completed 
on 1 June 1974 (Tuluksak River), one clutch hatched on 15 June 1974 (Platinum), and small downies were found on 18 June 1974 (Platinum) and 12 July 1974 and 1976 (Tuluksak River).

\section{Rock ptarmigan (Lagopus mutus). Upr.}

Rock ptarmigans occurred throughout the study area with the possible exception of the smaller offshore islands. We found ptarmigans at the Salmon River, the Tuluksak River, the Kisaralik River, the Kwethluk River, Platinum, and Cape Peirce. B. J. McCaffery (personal communication) found a female with eight young at the Kisaralik River on 20 June 1987. M. Brown et al. (unpublished) saw a bird at the Kisaralik River on 11 August 1985, and they found one at the Kwethluk River on 23 July 1985; R. Baxter (unpublished) and M. Brown et al. (17-29 June 1985; unpublished) saw them at the Eek River in summer; M. J. Fry (unpublished) saw them at Kagati Lake; White and Boyce (1978) found two males at the Kanektok River in June 1977.

In summer, birds were $350-600 \mathrm{~m}$ asl and in fall sometimes to 800-1,000 $\mathrm{m}$ asl. Ptarmigans used primarily subalpine shrub and dwarf shrub mat habitats. Flocks were at Cape Peirce in spring (28 April-2 May 1976), and pairs and singles were found there, at Slug Mountain, and Cape Newenham in summer (7 May-31 August).

\section{White-tailed ptarmigan (Lagopus leucurus). VRsr.}

In 1962, M.J. Fry (unpublished) found a female with four small young near Kagati Lake on 10 and 23 July. Single birds were seen at the Kwethluk River on 15 July 1985 and the Eek River on 18 June 1985 (M. Brown et al., unpublished). This ptarmigan has previously been reported as far west as Lake Clark (Osgood 1904; Gabrielson and Lincoln 1959; Williamson and Peyton 1962). Thus, the present record expands the western distribution of the white-tailed ptarmigan.

Ruffed grouse (Bonasa umbellus). Rpr. Specimen: RMS1988/037/01.

Ruffed grouse were rare at the Tuluksak River and were reported at the Salmon (C. Awe and J. Bloomquist, personal communication) and Kisaralik rivers (B. McCaffery, personal communication). One bird was said to have been shot during fall 1961 on the Tuluksak (C. Clark, Jr., personal communication), where we saw a female with seven young (about 3 weeks old) on 1 July 1974 and three birds on 11 October 1977. We also found a fox-killed chick at the Tuluksak River (DNW photo). Two females with young were reported (C. Clark, Jr., personal communication) at the Tuluksak River on 26 July 1979. Birds were found mainly in deciduous forests near old mining areas, usually on disturbed ground. 
Sandhill crane (Grus canadensis). Uspm, Asr, Afm (1 May- 21 September).

Sandhill cranes were abundant migrants along the coast in fall and were frequently found nesting in wetlands near the coast. Cranes migrated along the coast at Cape Peirce in spring 1970 (to 11 June), 1973 (4-29 May), and 1976 (1-20 May). Cranes were found along the coast during aerial surveys in spring, including 58 in 1985 (12 May; C. P. Dau, unpublished), 4 in 1986 (4 May; C. P. Dau, unpublished), 29 in 1988 (3 May; R. ). King and C. P. Dau, unpublished), and 7 in 1989 (4 May; R. J. King and C. P. Dau, unpublished). Cranes nested in wet meadows, dwarf shrub meadows, and grass meadows at $0-30 \mathrm{~m}$ asl along the coastal plain of the study area and in the lower portions of the rivers to the west of our study area. In a $260 \mathrm{~km}^{2}$ area from Ilanik Lakes to the Salmon River (Platinum), we found four pairs of cranes in 1974. At Cape Peirce, a nest with one pipped egg was found on 28 June 1984 (D. R. Herter et al., personal communication), a pair with two small young on 2 July 1973 (W. Arvey, personal communication) and on 23 June 1976 (MRP photo), and a family group during summer 1981 (D. R. Herter and D. Lloyd, personal communication). One chick in 1973 was predated by a raven. We saw adults near the Togiak River on 7-8 August 1973 and recorded fall migrants at the Tuluksak River (20 August-21 September) and Cape Peirce (14 August-7 September). Cranes were found at the Kwethluk River on 21 and 23 July 1985 (M. Brown et al., unpublished).

\section{Black-bellied plover (Pluvialis squatarola). Cspm, Cst, Cfm (1 May-1 October).}

Plovers migrated along coastal portions of the study area in spring and fall, nested at Goodnews and Chagvan bays (DNW photo), probably nested at Nanvak Bay, and nested on the tundra plain just west of our study area. Territorial birds were common at Goodnews and Chagvan bays in June 1974, on 15 July 1980, and on 15-17 July 1986; two broods of downy young were found at Platinum Spit on 18 July 1974. This is the farthest south that nesting has been recorded along coastal Alaskapreviously, the most southern coastal nesting area was at Hooper Bay (Gabrielson and Lincoln 1959; American Omithologists' Union 1983).

Singles and small groups of birds were seen almost daily in intertidal areas and wetlands adjacent to Nanvak Bay during spring migration $(<10$ birds per day, 1 May-8 June), and D. R. Herter and D. Lloyd (personal communication) found a pair of territorial plovers near Nanvak Bay on 4 July 1981. A pair of territorial birds were observed near Chagvan Bay in May 1987 (D. F. Parmelee and J. M. Parmelee, unpublished). P. D. Arneson and D. B. McDonald (personal communication) saw a nonbreeding-plumaged bird at Crooked Island on 20 June 1977. A pair of adults 
was seen on the lower Togiak River in August 1973. We observed fall migrants at Goodnews, Chagvan, Nanvak, and Togiak bays from 28 June to 26 September. At Nanvak Bay, birds were recorded daily with the largest number (72) seen on 20 July 1976. R. Gill, Jr., and B. Conant (unpublished) observed two birds at Goodnews Bay during an aerial survey on 1 October 1979.

Pacific golden-plover (Pluvialis fulva). Rspm, Rsr, Cfm ( 7 May1 October). Specimens: RMS1962/36/06 and RMS1962/36/07 (both collected near Bethel, Alaska).

Pacific golden-plovers migrated along the coast, nested in coastal areas and in the Ahklun Mountains, and were found in the Kilbuck Mountains. We found plovers during spring migration at Cape Peirce in 1973 ( $<15$ birds per day on 6 days, 7-17 May) but not in 1976. B. J. McCaffery (personal communication) found golden-plovers at the Kisaralik River on 17 June 1987. M. Brown et al. (unpublished) found one to five birds per day at the Kisaralik River on 10 and 15-19 August 1985, one to five birds per day at the Kwethluk River on 11-13, 16, 18-19, 25 , and 27 July 1985, and one bird per day at the Eek River on 24-26 June 1985. Based on the description in Connors (1983) and specimens collected at Bethel, territorial golden-plovers in our area are most similar to $P$. fulva. They nested at Platinum, (downies and adults; DNW photo) and possibly at the Kinegnak River (near Goodnews Bay), Chagvan Bay, and Cape Peirce. At Platinum, we found an "anxious" pair on 13 June 1974 and two pairs and a female with two downies on 3 August 1988. One bird performed a distraction display on the lower slopes of Slug Mountain on 10 June 1973, and another pair was seen there. D. R. Herter et al. (personal communication) also found birds at Cape Peirce on 28 June 1984. Territorial pairs and spring migrants used dwarf scrub mat and grass meadows along gentle slopes of hills and mountains. Fall migrants were common on the Cape Peirce peninsula and intertidal flats at Nanvak Bay between 16 August and 25 September. Our highest fall count there was 41 birds on 19 September 1973. Golden-plovers were seen at Platinum in fall on 23 July 1974 and 15 July 1980 and at the Togiak River on 7 August 1973. Thirty birds were observed during an aerial survey of the coast at Jacksmith Bay and 3 at Nanvak Bay on 1 October 1979 (R. Gill, Jr., and B. Conant, unpublished).

\section{Mongolian plover (Charadrius mongolus). VRsr.}

Bull collected an adult male Mongolian plover (in Friedmann 1934) and three eggs (in Friedmann 1936) at the mouth of Barnum Creek on Goodnews River on 10 June 1933. A single bird was seen at Nanvak Bay on 5 June 1973. 
Semipalmated plover (Charadrius semipalmatus). Asr, Ufm (5 May- 17 September). Specimen: WFB862.

This plover was found throughout the study area. Birds nested at the Salmon River, the Tuluksak River (DNW photo), Kisaralik Lake and the Kisaralik River, Goodnews Bay (DNW photo), Chagvan Bay, Nanvak Bay (MHD photo), and Cape Peirce, and possibly the Togiak River and Togiak Lake. Birds were also found in summer at the Eek River (R. Baxter, unpublished; M. Brown et al., unpublished), nested at Kagati Lake (M. J. Fry, unpublished), and were found at Kancktok River (White and Boyce 1978; J. L. Hout, personal communication) and the Kwethluk River (M. Brown et al., unpublished). P. D. Ameson and D. B. McDonald (personal communication) found nesting birds at Crooked Island JuneJuly 1977) and suspected that nesting occurred at Summit, High, and Hagemeister islands. D. F. Parmelee and J. M. Parmelee (unpublished) found nesting birds near Chagvan Bay in 1987.

Nests and birds performing territorial displays were on beaches, bare lake and river shores and bars, coastal and inland block-fields, airstrips, roads, and mine tailings to $450 \mathrm{~m}$ asl. B. J. McCaffery (personal communication) found a bird performing nest distraction displays at the Kisaralik River on 16 June 1987. M. J. Fry (unpublished) found 50-90 pairs nesting around Kagati Lake in 1962. At Cape Peirce and Nanvak Bay, eggs were laid beginning in late May; one clutch was completed on 24-25 May 1970, one nest had four eggs hatch on 18 June 1970, and one pair was still incubating on 23 June 1973. D. R. Herter and D. Lloyd (personal communication) found single broods with one chick each on 10 and 12 July 1981 , and D. R. Herter et al. (personal communication) found single broods of two chicks on 25 and 28 June 1984 at Nanvak Bay. Young were seen at the Tuluksak River beginning on 26 June 1962 and 8 July 1973. In 1987, a nest near Chagvan Bay contained one egg on 24 May, two eggs on 26 May, and three eggs on 27 May (D. F. Parmelec and J. M. Parmelee, unpublished). We found eggs hatching beginning on 18 June 1974 in the Goodnews-Chagvan Bay area, where five pairs had young in ages varying from small downy to recently fledged and fledged on 17-20 July 1974. Birds generally left their nesting areas between 26 July and 10 August. We found fall migrants at Nanvak Bay until 17 September 1973.

\section{Black oystercatcher (Haematopus bachmani). VRsr.}

Eley (1976) found a pair of oystercatchers with two small young on Round Island on 15-21 July 1974. We saw none there in 1962, and none were recorded elsewhere on the study area. 
Greater yellowlegs (Tringa melanoleuca). Uspm, Asr, Ufm (30 April- 4 October). Specimens: UAM2678 and RMS1962/36/15.

Greater yellowlegs migrated along the coastal portion of the study area and used rivers and streams throughout the study area. We found breeding birds at the Salmon River, the Tuluksak River (scolding aduits, DNW photo), the Kisaralik River, and the Togiak River and migrants at Cape Peirce and Nanvak Bay. Birds probably nested at Kagati Lake (M. J. Fry, unpublished). Yellowlegs were seen in summer at the Kisaralik River (16-21 June 1982 [B. J. McCaffery, personal communication]; 17 August 1985 [M. Brown et al., unpublished]), at the Kwethluk River (12-27 July 1985; M. Brown et al., unpublished), at Kanektok River (White and Boyce 1978), and at the Eek River (R. Baxter, unpublished; 18-29 June 1985 [M. Brown et al., unpublished]). D. R. Herter et al. (personal communication) saw a bird at Cape Peirce on 25 June 1984, and P. D. Arneson and D. B. McDonald (personal communication) saw a bird at Crooked Island on 27 June 1977 . We found two to five pairs of birds each year at the Tuluksak River at freshwater marshes near major streams.

We found groups of one to three birds at Nanvak Bay each spring (30 April-29 May) and fall (5 August-24 September). Peak numbers (6-49 birds) generally occurred between 15 and 29 August, and few birds were seen in late September. Forty-five yellowlegs were in Chagvan Bay on 4 October 1980 (R. Gill, Jr., and R. King, unpublished). Yellowlegs were generally gone from the Tuluksak River by 11 August 1977.

Lesser yellowlegs (Tringa flavipes). VRv, Rst? (29 May-4 August). Specimen: WFB864.

We saw a few pairs at the Tuluksak, Kisaralik, and Kanektok rivers. Mindell (1983) found them uncommon in the Nyac area, and M. Brown et al. (unpublished) found one bird each on 15 and 18 August 1985 at the Kisaralik River. R. Baxter (unpublished) found birds at the Eek River in August 1976, and J. L. Hout (personal communication) found them at the Kanektok River in August 1973. At the Tuluksak River, six pairs were found in 1962, four pairs in 1974, two pairs in 1976-79, and no birds in 1980-81, 1983, or 1986-87 along $48 \mathrm{~km}$ of major streams. Birds were found at Cape Peirce in 1976 (10 June-12 July; this study), and 1984 (16 June; D. R. Herter et al., personal communication).

Solitary sandpiper (Tringa solitaria). VRv, Usr (19 May-24 August). Specimen: RMS1962/36/12.

Sandpipers were occasionally seen in the coastal portion of the study area and nested in the Kilbuck Mountains. We saw one bird at Cape Peirce on 19 May 1976, as did D. R. Herter and D. Lloyd (personal communica- 
tion) on 24-26 July 1981. We saw two birds at Goodnews Bay on 23 July 1974. It was an uncommon-to-rare breeding bird in the northern Kilbuck Mountains; they nested at the Tuluksak River (scolding adults, DNW photo) and possibly at the Salmon and Kisaralik rivers. Two to four pairs nested each year near lacustrine waters or slowly flowing beaver ponds in dense spruce or spruce-poplar riparian areas at the Tuluksak River. We found pairs with small young at the Tuluksak River on 24 June 1974 and 26 June 1978; adults were seen until 10 August 1977, and immatures were present until 5 August 1962 and 24 August 1974.

Wandering tattler (Heteroscelus incanus). Uspm, FCsr, Ufm (14 May- 5 September). Specimens: WFB863, RMS1962/36/13, RMS1962/36/14, RMS1974/119/09, RMS1974/119/10, BMNH/83sk/DNW13, and BMNH/ 83sk/DNW14.

Tattlers nested in the Kilbuck Mountains, probably nested in the Ahklun Mountains, and migrated along the coast. We found nesting birds at the Salmon and Tuluksak rivers (DNW photo), and they probably nested at the Kisaralik and Togiak rivers; birds were found in summer at the Eek (R. Baxter, unpublished) and Kanektok rivers (White and Boyce 1978; M. J. Fry, unpublished; J. L. Hout, personal communication). Birds were also found at the Kisaralik River on 19 and 24 August 1985 (M. Brown et al., unpublished).

Pairs of wandering tattlers were $90-300 \mathrm{~m}$ asl (once at $500 \mathrm{~m}$ ) along shores of streams usually $>9 \mathrm{~m}$ wide. Tattlers were usually fairly common at the Tuluskak and Salmon rivers, but in 1986 they were exceptionally scarce with only one bird seen on each river. Densities were greater in riparian mine tailings than in comparable undisturbed river shingles on the Tuluskak River; we found $0.6-2.5$ broods per $\mathrm{km}$ per year in riparian mine tailings, and 0.6 broods per $\mathrm{km}$ per year along undisturbed river shingle. Birds may have nested in more wooded tributaries adjacent to larger streams, as adults frequently escorted small young from smaller streams to main streams. At the Tuluksak River, we collected two adults with incubation patches on 1-2 June 1962, found pairs with small young between 27 June and 6 July, found fully feathered chicks on 10 July 1962 and 21 July 1976, and last saw young between 15 and 20 August. We found fledged young at the Togiak River on 6-9 August 1976.

We found birds at Goodnews and Chagvan bays in spring and fall. During spring migration at Cape Peirce we saw one to two birds between 14 May and 12 June, totaling seven or fewer observations each spring. D. F. Parmelee and J. M. Parmelee (unpublished) saw single birds on 23 and 26 May 1987 at Chagvan Bay. D. R. Herter et al. (personal communication) found a tattler at Cape Peirce on 6 June 1984. Birds were at Round Island between 14 and 23 July 1974 (T. J. Eley, unpublished), and one was there on 14 July 1977 (P. D. Arneson and D. B. McDonald, personal 
communication). In fall, we found 1-10 tattlers at Cape Peirce most days from 17 July to 5 September (young only on 31 August-5 September), and found adults at Goodnews Bay on 19-20 July 1974.

Spotted sandpiper (Actitis macularia). FCspm, Asr, FCfm (26 May28 August). Specimen: RMS1962/36/11.

Spotted sandpipers were along the coastal portion of the study area during spring and fall and nested throughout the area. We found them nesting at the Salmon, Tuluksak, Kisaralik, and Togiak rivers. Sandpipers were also found by others in summer near Nyac (Mindell 1983), at the Kisaralik River (Mindell 1983; M. Brown et al., unpublished; B. J. McCaffery, personal communication), at the Eek River (R. Baxter, unpublished; M. Brown et al., unpublished), at Kagati Lake (M. J. Fry, unpublished), at the Kwethluk River (M. Brown et al., unpublished), and at the Kanektok River (White and Boyce 1978).

At the Tuluksak River, spotted sandpipers (DNW photo) were the most common shorebird nesting near fluviatile waters, especially in old mine tailings, to $365 \mathrm{~m}$ asl and well above the riparian timberline. Along disturbed and undisturbed riparian habitat within the timberline, we found 6.9 pairs per square kilometer in 1983. At the Tuluksak River, we found eggs on 15 June, newly hatched young between 28 June and 14 July, and newly fledged young between 27 July and 3 August 1983. Most breeding birds had left the Tuluksak River area by 10-19 August, and some migrated through on 28 August 1974. Birds were seen as late as 28 August 1985 at the Kisaralik River (M. Brown et al., unpublished). We recorded two birds each day on 23 and 30 May 1976 at Cape Peirce, and one was seen there (D. R. Herter and D. Lloyd, personal communication) on 24July 1981. We also saw migrants at Goodnews and Chagvan bays in July 1974, and T. J. Eley (unpublished) found one bird each day at Round Island on 15,18 , and 21 July 1974 .

Terek sandpiper (Xenus cinereus). VRv. Specimen: UAM2630.

The first specimen for North America was collected by M. H. Dick in the marsh south of Nanvak Bay on 27 May 1973. Since then several other birds have been reported in Alaska (Kessel and Gibson 1978). An adult in alternate plumage was in wetlands adjacent to Nanvak Bay on 14 May 1976.

Whimbrel (Numenius phaeopus). Rst?, Cfm (20 May-17 September). Specimens: YDNWR(MHD 70-16), YDNWR(no specimen number).

Whimbrels probably nested along the coast and were found elsewhere on the study area. Birds were seen at Cape Peirce and Nanvak Bay (9 June 1970 and 20 May 1976) and at Goodnews and Chagvan bays June-July 1974, 15 July 1980). D. R. Herter and D. Lloyd (personal 
communication) also found them at Cape Peirce and Nanvak Bay in 1981, as did D. R. Herter et al. (personal communication) in June and July 1984. Pairs alarm-called repeatedly in the same areas at Goodnews and Chagvan bays in June and July 1974, and a single bird circled and alarm-alled at Nanvak Bay on 10 June 1970. J. L. Hout (personal communication) found five birds near Platinum on 28-29 July 1969. Inland, B. J. McCaffery (personal communication) saw whimbrels on 16 June 1987 at the Kisaralik River; M. J. Fry (unpublished) saw one bird on 21 July 1962 at Kagati Lake; R. Baxter collected one $8 \mathrm{~km}$ north of Eek Lake on 11 August 1976 (YDNWR, no specimen number). We found whimbrels during fall migration throughout the study area at the Kisaralik River, Goodnews Bay, Chagvan Bay, Cape Peirce, Nanvak Bay, and the Togiak River. Fall migration began as early as 22 June and continued into September; however, most migrants were seen between 14 August and 4 September. Flocks of up to 75 birds were seen in fall at Nanvak Bay; the highest count was 116 birds on 27 August 1973.

\section{Bristle-thighed curlew (Numenius tahitiensis). VRv, Rfm.}

In 1962, curlews were seen at Kagati Lake on 14 July (three birds), 18 July (three birds), and "on another occasion" (M. J. Fry, unpublished). We found them at Goodnews Bay on 15 July 1980, Platinum Spit on 17 July 1986, and the Togiak River on 9 August 1973, and during fall migration at Nanvak Bay in 1973 ( 5 days between 25 August and 8 September). D. R. Herter and D. Lloyd (personal communication) saw one bird each day on 13 and 14 August 1981 at Nanvak Bay. These observations suggest that bristle-thighed curlews continue their southward migration at least part of the way along the coast after leaving the Yukon-Kuskokwim Delta and arriving at south-coastal Alaska.

Hudsonian godwit (Limosa haemastica). Rfm.

This species was found only along the coast during fall migration. We found a single bird feeding at Nanvak Bay on 16 August 1973, and eight birds fed there on 20 August 1976. Also at Nanvak Bay, D. R. Herter and D. Lloyd (personal communication) found flocks of 10,3, and 1 birds on 21 July, 1 August, and 11 August 1981, respectively, and D. R. Herter et al. (personal communication) found 1 on $9 \mathrm{July}$ and saw 1 or more on $19 \mathrm{July}$ 1984. Six distant godwits, probably this species, were traveling south along the coast near Goodnews Bay on 23 July 1974.

Bar-tailed godwit (Limosa lapponica). VRspm, VRv, FCfm (5 May1 October).

We saw these godwits twice during spring migration: five birds on 20 May 1973 and one bird on 5 May 1976 at Nanvak Bay. White and Boyce 
(1978) saw one on 19 June 1977 near the foothills at the Kanektok River. In 1973, fall migrants were common at Nanvak Bay and Cape Peirce, but none were observed in 1970 or 1976. D. R. Herter and D. Loyd (personal communication) found them there in 1981, and D. R. Herter et al. (personal communication) saw godwits on 19 July 1984 . Fall migration began before 14 August and continued until 25 September 1973, with the largest number of birds seen from 14 to 21 August (highest count of 215 birds on 20 August). Birds were still present into October-350 godwits were in Jacksmith Bay and 1,945 in Carter Bay during an aerial survey on 1 October 1979 (R. Gill, Jr., and B. Conant, unpublished).

Ruddy turnstone (Arenaria interpres). Uspm, Ufm (4 May-22 September).

Ruddy turnstones used the coastal portion of the study area. During spring migration at Nanvak Bay (4-29 May), we saw up to five birds each day on 6 days in 1973 and 2 days in 1976. Fall migrants were at Chagvan Bay ( 30 birds on 21 July 1974) and Nanvak Bay (17 July-22 September). Most fall migrants were at Nanvak Bay between 3 and 18 August. Small flocks of one to seven birds were seen daily to as late as 22 September. Most birds were along the beach or at rivers on gravel or sandy substrates.

Black turnstone (Arenaria melanocephala). Uspm, Usr, Ufm ( 5 May-15 September). Specimen: RMS1962/36/10.

Turnstones migrated past Cape Peirce in spring and along the coastal portion of the study area and inland in fall. In spring, small flocks, pairs, and single birds were seen irregularly each year between 5 and 29 May at Cape Peirce and Nanvak Bay. A single bird was at Chagvan Bay on 26-27 May 1987 (D. F. Parmelee and J. M. Parmelee, unpublished). Adults in altemate plumage displayed at Ilanik Lakes (DNW photo) on 1319 June 1974 and Togiak Bay on 6-9 July 1962. Bull (in C. M. Handel and R. E. Gill, Jr., 1992) collected 14 clutches during May-June 1932-34 at Goodnews Bay. We found adults with chicks at Goodnews Bay on 16 July 1986. Fall migrants fed on dead salmon far inland along the Kisaralik River on 30-31 July 1979 (this study), July 1984 (D. A. Boyce and S. J. Fristensky, unpublished), and 8-9 and 15 August 1985 (M. Brown et al., unpublished) and along the Aniak River on 10 August 1979 (10 birds). J. L. Hout (personal communication) saw a bird at the Kanektok River on 6 August 1973, and we found birds at the Togiak River between 4 and 9 August 1973. Flocks were along the coast between 20 July and 15 September. We found birds near Goodnews Spit on 14-15 September 1977, at Chagvan Bay on 20-23 July 1974, and at Togiak Bay on 6-9 August 1973. J. L. Hout (personal communication) found flocks at Good- 
news Bay between 23 and 29 July 1969 . We collected an adult female black turnstone, probably nesting, at the confluence of the Tuluksak and Kuskokwim rivers just outside our study area on 16-17 June 1962.

Surfbird (Aphriza virgata). Uspm, FCsr (19 May-12 August). Specimens: RMS1962/36/08 and RMS1962/36/09.

Surfbirds nest in northern and probably in southem parts of the study area and migrate along the coast. Birds were found along the rocky coast at Cape Peirce in 4 of 6 years: during 3 days between 18 and 28 June 1976 (this study), 2 days between 27 and 30 July 1981 (D. R. Herter and D. Lloyd, personal communication), 8 June and 18 July 1984 (D. R. Herter et al., personal communication), and 8 days between 15 May and $9 \mathrm{Au}$ gust 1990 (K. Winker and J. Klicka, unpublished). A single and three birds were observed among rock sandpipers (Calidris ptilocnemis) at Chagvan Bay on 26 and 27 May 1987, respectively (D. F. Parmelee and J. M. Parmelee, unpublished). One male surfbird was collected by Bull (in Friedmann 1934) at Goodnews Bay on 12 August 1933. P. D. Arneson and D. B. McDonald (personal communication) saw a surfbird at Crooked Island on 5 July 1977. Birds nested at the Tuluksak River (this study) and at the Salmon River J. Bloomquist, personal communication), and were seen at the Kisaralik River on 20 June 1987 (B. J. McCaffery, personal communication) and the Eek River on 18 and 28 June 1985 (M. Brown et al., unpublished). We flushed pairs from appropriate nesting habitat at Tokomarik Mountain near Cape Newenham on 19 May 1973; an adult female with an egg in the oviduct was collected on 22 May 1990 at Cape Peirce (K. Winker and J. Klicka, unpublished).

At the Tuluksak River, calling adults or chicks were found or reported at two locations in 1961, up to five in 1962, two in 1974, zero in 1976-79, and one each in 1981 and 1983. All sites were 600-900 m asl on ridges or plateaus $90-350 \mathrm{~m}$ wide and in dry dwarf shrub meadows, block-fields, and screes. An incubating adult was found on 4 June 1974 and a small downy chick found on 26 June 1962. Adults performed distraction displays on 4 July 1981 and $4 \mathrm{July} 1983$, and an almost fully feathered chick was found on 2 August 1962. Remains of an adult were found in pluckings near a gyrfalcon nest on 9 July 1987. Adults had apparently left the Tuluksak River area by 2 August 1962.

Red knot (Calidris canutus). VRfm.

In 1981, D. R. Herter and D. Lloyd (personal communication) found two knots at Nanvak Bay on 8 August and one on 10 August. J. L. Hout (personal communication) found flocks of five to six birds at Chagvan Bay between 23 and 28 July 1969. 
Sanderling (Calidris alba). Uspm, Cfm (12 May-1 October).

Sanderlings were common migrants along the coast. They were at Nanvak Bay in spring (12-31 May) and fall ( 5 July-25 September) in most years; J. G. King (unpublished) reported a flock there on 5 July 1964. A single bird was at Chagvan Bay on 20 May 1987 (D. F. Parmelee and J. M. Parmelee, unpublished). Fall migration was most intense after 8 September when birds were sighted almost daily-peak counts totaled 118 birds on 11 September 1973 . Flock sizes were generally small (1-8 birds) during spring migration and larger (to 80 birds) during fall migration. Five birds were seen from Carter Bay to Goodnews Bay and 11 at Chagvan Bay during an aerial survey on 1 October 1979 (R. Gill, Jr., and B. Conant, unpublished).

Semipalmated sandpiper (Calidris pusilla). Rsr, Ufm (22 May-24 September). Specimens: UAM2633, UAM2634 and RMS1974/119/20.

Pairs of semipalmated sandpipers were observed beginning 22 May 1987 near Chagvan Bay "at the edge of marshy ponds near the camp site and also on the banks over looking Emperor Creek where territorial skirmishes were conspicuous" (D. F. Parmelee and J. M. Parmelee, unpublished). We looked carefully for breeding birds but saw none, although they nest near our area in Bethel where DNW took a breeding pair on 18 June 1962 . At the Eek River, one to five birds per day were seen on 19 June and one bird was seen on 21 June 1985 (M. Brown et al., unpublished). A few semipalmated sandpipers migrated through Nanvak Bay in fall (1-24 September). Birds fed on the mudflats in the bay with other small sandpipers and may often have been overlooked. Semipalmated sandpipers were positively identified in 1973 when individuals were collected in September from flocks of small sandpipers; birds in mixed species flocks were identified by field characteristics in other years.

Western sandpiper (Calidris mauri). Asr, Afm (1 May-16 September). Specimen: YDNWR(MHD-70-30).

Western sandpipers (Fig. 14) nested inland in the Kilbuck Mountains, and nested and migrated along the coast. We found nesting birds at the Tuluksak and Kisaralik rivers and along the coast near Goodnews Bay (DNW photo), Nanvak Bay, and Cape Peirce. P. D. Ameson and D. B. McDonald (personal communication) found nesting birds at Crooked Island in June-July 1977 . In the Kilbuck Mountains, we found 3-4 pairs of western sandpipers nesting each year at the Tuluksak River ( $90 \mathrm{~m}$ asl) and 25-50 pairs nesting at Kisaralik Lake ( $450 \mathrm{~m}$ asl) in 1979 . Along the coast, several pairs nested each year to $50 \mathrm{~m}$ asl at Cape Peirce, and large numbers of birds nested from Goodnews Bay to Chagvan Bay in 1974. 


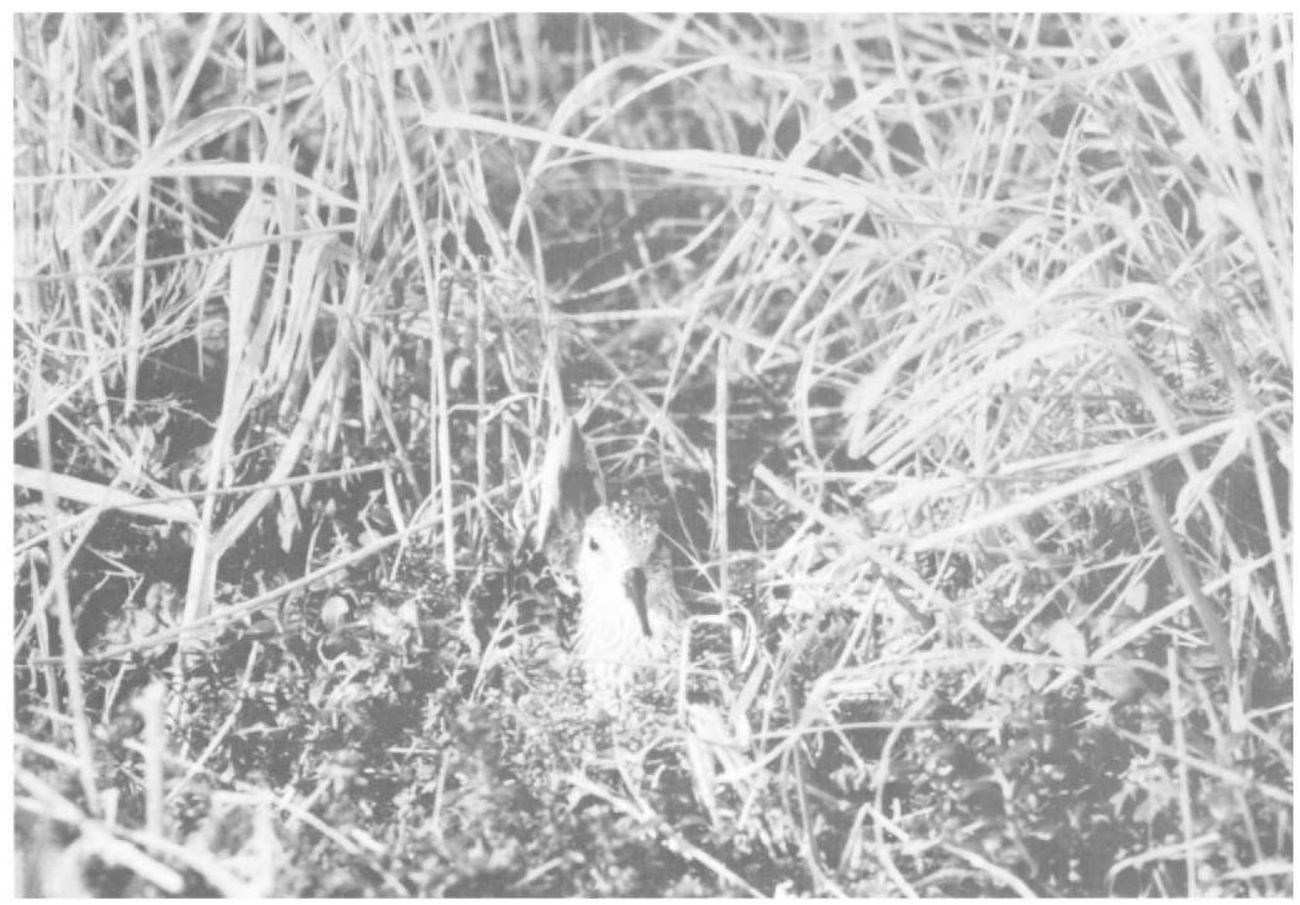

Fig. 14. Western sandpiper on a nest in typical nesting habitat. Photo by M. R. Petersen.

Nesting pairs used dwarf shrub mat and dwarf shrub meadows along the coast and treeless bogs, wet dwarf shrub meadows, and dwarf shrub mat habitats inland. At Cape Peirce and Nanvak Bay, birds arrived early in spring (1-3 May) and began acrial displays above their nesting habitat on 13-16 May. Pairs and singles were present at Chagvan Bay on 20-27 May 1987, although no aerial displays were seen (D. F. Parmelee and J. M. Parmelee, unpublished). J. Sargent observed a pair copulating there on 20 May 1987 (in D. F. Parmelee and J. M. Parmelee, unpublished). In all years at Cape Peirce, complete clutches of four eggs were found between 31 May and 19 June, and fledged young were common on the mudflats of Nanvak Bay by mid-July. Most adults were absent from nesting territories by early July and from intertidal areas by early August.

Western sandpipers were abundant fall migrants along the coast, primarily in estuarine areas, at the mouths of rivers, and at mudflats. Fall migrants were common at Nanvak Bay beginning 25 June (peak, 509 birds on 20 August 1973) and at Goodnews and Chagvan bays and the Kisaralik River in July. M. Brown et al. (unpublished) found one to five birds per day on 8, 9, and 11 August 1985 at the Kisaralik River. A few birds remained at Nanvak Bay as late as 16 September. $R$. MacIntosh (unpub- 
lished) saw six birds on Round Island on 27 June 1976, and P. D. Arneson and D. B. McDonald (personal communication) found birds at Hagemeister Island on 9 July 1977.

Least sandpiper (Calidris minutilla). Usr, FCfm (10 May-3 September). Specimens: RMS1962/36/13 and UAM2646.

Least sandpipers migrate through and probably nest in the Kilbuck Mountains, and nest and migrate along the coast. This sandpiper probably nested inland at the Tuluksak River and nested along the coast at Nanvak Bay, Cape Peirce, and possibly Goodnews and Chagvan bays. It also nested on Crooked Island in 1977 (P. D. Arneson and D. B. McDonald, personal communication). Territorial pairs, nests, and broods were in wet meadows adjacent to estuarine and lacustrine waters from sea level to $360 \mathrm{~m}$ asl. At Cape Peirce and Nanvak Bay, we found pairs performing territorial displays on 12 May-19 June and copulating on 17 May; we found eggs in nests between 26 May-20 June. D. R. Herter and D. Lloyd (personal communication) found eggs in nests there on 19 June and 1-to 4-day-old chicks on 25 June and 3 July 1981; J. G. King (unpublished) found a nest there with four eggs on 5 July 1964; D. R. Herter et al. (personal communication) found a brood of two young on 19 June 1984. Adults generally left their breeding areas at Cape Peirce and Nanvak Bay by mid-July, and juveniles left by early to mid-August.

Sandpipers were seen in "swampy areas near tidal inlets" at Chagvan Bay on 21-24 May 1987 (D. F. Parmelee and J. M. Parmelee, unpublished). Inland on the Tuluksak River, one to three pairs probably nested at each marshy pond in wet meadows near or above timberline (250 and $360 \mathrm{~m}$ asl). Least sandpipers were at the Kisaralik River on 17 June 1987 (B. J. McCaffery, personal communication) and at the Eek River on 18-25 June 1985 (M. Brown et al., unpublished).

Fall migrants passed inland along the Tuluksak and Kisaralik rivers between 15 and 30 July each year and were found at Togiak Lake and the Togiak River on 3-5 August 1973. In 1985, M. Brown et al. (unpublished) found them at the Kisaralik River on 8-17 August and at the Kwethluk River on 12, and 23-27 July. Few migrant least sandpipers were found along the coastal portion of the study area; P. D. Arneson and D. B. McDonald (personal communication) saw a bird at Hagemeister Island on 10 July 1977, and we saw an immature bird at Cape Peirce on 3 September 1973.

Baird's sandpiper (Calidris bairdii). VRspm, VRfm. Specimen: UAM3118.

We saw Baird's sandpipers at Nanvak Bay on 14 August 1970 (one bird) and on 6 and 8 September 1973 (one and four birds, respectively). 
A single individual was seen on 22 May 1987 at Chagvan Bay (D. F. Parmelee and J. M. Parmelee, unpublished). One bird was seen at Togiak Lake on 3 August 1973, and one was seen in the Kilbuck Mountains near the Aniak River on 31 July 1986 . In 1985, one bird was seen each day of 21 and 22 June at the Eek River, one bird each on 8, 9, and 12 August, and 1-5 birds on 13 August at the Kisaralik River (M. Brown et al., unpublished).

Pectoral sandpiper (Calidris melanotos). VRspm, VRsr, Rfm.

A few pectoral sandpipers migrated along the coast and nested there in some years. We found pectoral sandpipers during spring migration at Nanvak Bay only in $1976(16,23$, and 24 May); D. R. Herter et al. (personal communication) found one there on 13 June 1984. Bull (in Friedmann 1933) found nesting birds at Goodnews Bay in 1933 and B. Huffmon (personal communication) reported them nesting there more recently, but we did not find them in June-July 1974. We found a few flocks of one to five birds in Nanvak Bay in fall (five birds between 11 and 24 September 1973 and five birds 13 August 1976). D. R. Herter and D. Lloyd (personal communication) saw one bird there on 5 August 1981.

Sharp-tailed sandpiper (Calidris acuminata). Rfm. Specimens: UAM2632 and UAM3174.

We recorded 1-14 sandpipers each day at Nanvak Bay on 26 August 1970 and 6 days between 7 and 24 September 1973. Birds were flushed from beach rye (Elymus arenarius mollis) or along brackish ponds adjacent to the bay.

Rock sandpiper (Calidris ptilocnemis). Cspm, Asr, Afm (23 April1 October). Specimens: UAM2635, UAM2636, RSM1974/119/18, and RSM1974/119/03.

This species migrated along the coastal portion of the study area in spring and fall and nested along the coast and on offshore islands. T. J. Eley (unpublished) found flightless young on Round Island on 14-23 July 1974. P. D. Arneson and D. B. McDonald (personal communication) found birds on Round, Summit, Crooked, and Hagemeister islands in July 1977.

We found breeding birds at Goodnews Bay, Nanvak Bay, and Cape Peirce in dwarf shrub mat habitat. In 1973, rock sandpipers first arrived at Nanvak Bay on 28 April, and most individuals were in prealternate molt and on territories at Cape Peirce (MHD photo) by 5 May. At Cape Peirce in 1970, 1973, and 1976, we found nests with eggs between 27 May and 20 June, broods between 17 and $28 \mathrm{June}$, and adults gone from the nesting area by 25 July; H. P. Brokaw (unpublished) found a nest there with four eggs on 26 June and a downy young on 28 June 1970. At Chagvan Bay 
birds were found along the beaches and inland "in the well drained tundra areas" and were on territories beginning 22 May 1987 (D. F. Parmelee and J. M. Parmelee, unpublished).

During spring and fall migration, birds used estuarine (Chagvan and Nanvak bays) and rocky intertidal (Cape Peirce) areas. Spring migration at Nanvak Bay was from 28 April to 27 May 1973, with most birds seen 7-17 May (200 birds per day, flocks of up to 130 birds). During an aerial survey, C. P. Dau (unpublished) estimated 6,000 rock sandpipers in Jacksmith Bay on 23 April 1981. Fall migrants arrived beginning 20 July and remained common into September. At Nanvak Bay in 1973, numbers of birds increased from late August, and the highest concentrations were found from 13 to 17 September (peak, 326 birds; 16 September). Birds were still present there on 26 September 1973 and were reported by J. L. Hout (personal communication) as late as 30 September in 1971. Rock sandpipers were in Goodnews Bay on 28-29 July and Chagvan Bay on 23-28 July 1969 J. L. Hout, personal communication). An estimated 407 birds were in Chagvan Bay and 34 in Nanvak Bay during an aerial survey on 1 October 1979 (R. Gill, Jr., and B. Conant, unpublished).

Dunlin (Calidris alpina). Uspm, Csr, Cfm (3 May-1 October). Specimen: RMS1974/119/19.

Dunlins used only the coastal portion of the study area. Nesting was confirmed only at Ilanik Lakes where one newly hatched chick was found on 15 June 1974. Dunlins were present and probably nested near the mouth of the Togiak River during 68 July 1962 . A few birds migrated through Nanvak Bay in spring 1976 (3-24 May), with a maximum of 61 seen on 3 May. During early fall migration, $T$. J. Eley (unpublished) found three birds in 10 days in July 1974 at Round Island. J. L. Hout (personal communication) found dunlins common near Chagvan Bay between 23 and 28 July 1969 . We found fall migrants at Chagvan Bay in July, they were first at Nanvak Bay on 13 August 1970 and 18 August 1973, and they were common in most estuaries from late August to late September. Birds found at Nanvak Bay in August were mainly adults and in September were mostly juveniles; dunlins were there as late as 26 September. Dunlins were present along the coast during an aerial survey on 1 October 1979 when 60 were observed in Jacksmith Bay, 365 from Jacksmith Bay to Carter Spit, 8,052 from Carter Bay to Carter Spit, 1,142 in Goodnews Bay, 154 in Chagvan Bay, and 422 in Nanvak Bay (R. Gill, Jr., and B. Conant, unpublished).

Short-billed dowitcher (Limnodromus griseus). Rspm?, Rsr?, Cfm (5 May-25 September). Specimen: UAM2637.

Short-billed dowitchers were found only in coastal areas. Dowitcher eggs collected by Bull on 6 June 1932 at Ilanik Lakes, Goodnews Bay, 
were thought to be of short-billed dowitchers (Pitelka 1950); we found adult short-billed dowitchers giving alarm calls there on 14 June 1974. A few small flocks (up to 37 birds) of dowitchers passed Nanvak Bay between 5 and 30 May in 2 of 3 years (1970 and 1973). Field identification of dowitcher species was difficult and only positively made in mixed species flocks and when calls were heard. During the 1977 fall migration, dowitchers (some giving alarm calls) were common near Goodnews Bay on 23 July and were still in the area on 14-15 September. Based on observations of adults, both species were suspected to be present. In fall 1981, short-billed dowitchers appeared at Nanvak Bay in late July-early August (D. R. Herter and D. Lloyd, personal communication). They were there around mid-August in 1970 and 1973, but none were seen there in 1976. The greatest number was found in 1973 on 24 September (124 birds), and they were present until at least 25 September 1973.

Long-billed dowitcher (Limnodromus scolopaceus). Rspm, Rsr?, Cfm (5 May-22 September). Specimens: UAM2638, UAM2639, UAM2640, and UAM2641.

As with short-billed dowitchers, long-billed dowitchers were found only at coastal locations. Bull thought that both species bred at Ilanik Lakes (B. Huffmon, personal communication). We identified a long-billed dowitcher in spring 1973 ( 5 May) at Nanvak Bay, but positive identification of most individuals was not made (see short-billed dowitcher section). D. R. Herter et al. (personal communication) found a dowitcher of unknown species at Cape Peirce on 24 June 1984. Most or all of a flock of 30 birds in prebasic molt, photographed on 23 July 1974 at Goodnews Spit (Fig. 15), were long-billed dowitchers. Long-billed dowitchers generally arrived at Nanvak Bay beginning in late July and peaked during the third or last week of August; up to 91 birds per day were seen during peak migration in 1973.

Common snipe (Gallinago gallinago). Csr (28 April-21 September). Specimen: YDNWR(MHD 69-2).

Snipes were common throughout the study area each year. We found breeding birds at the Tuluksak River and suspected nesting at other inland locations. They were seen in summer near Nyac (Mindell 1983), at the Kisaralik River (Mindell 1983; M. Brown et al., unpublished; B. J. McCaffery, personal communication), at the Eek River (R. Baxter, unpublished; M. Brown et al., unpublished), at the Kwethluk River (M. Brown et al., unpublished), at Kagati Lake (M. J. Fry, unpublished), and in the Kanektok River area (White and Boyce 1978). Along the coast, birds nested at Nanvak Bay (this study; MHD specimen), probably nested at Chagvan Bay (D. F. Parmelee and J. M. Parmelee, unpublished), and were suspected 


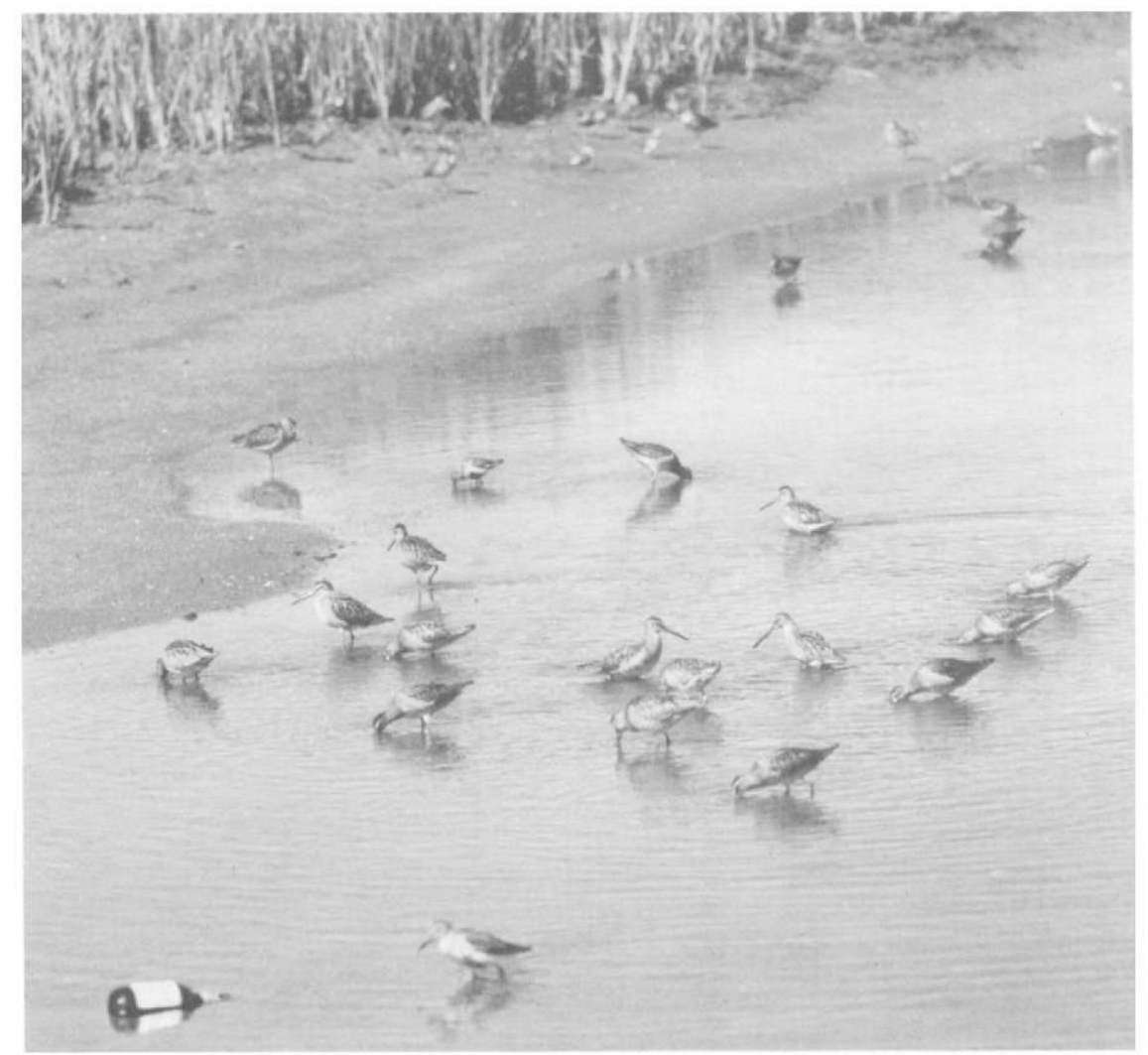

Fig. 15. Long-billed dowitchers feeding at Goodnews Spit, 23 July 1974. Photo by $D$. N. Weir.

to nest at Crooked Island (P. D. Arneson and D. B. McDonald, personal communication).

Along the coast, snipes displayed over the marsh adjacent to Nanvak Bay as early as 28 April (28 April-22 June), and just-fledged young were there in early August; no snipes were seen there after 5 September 1973. Displaying males were first noted at Chagvan Bay on 24 May 1987 (D. F. Parmelee and J. M. Parmelee, unpublished), and birds were present on Crooked Island in June-July 1977 (P. D. Arneson and D. B. McDonald, personal communication). Inland at the Tuluksak River, birds displayed until late July; an early brood was just flying on 19 June 1983; partially feathered young were found between 10 and $15 \mathrm{July}$; and most birds gone from the area by 20 August. However, an exhausted migrant was seen there on 21 September 1977. At the Kisaralik River, snipes were present on 12-13 and 25-26 August 1985 (M. Brown et al., unpublished) and present at the Kwethluk River on 12-17 July 1985 (M. Brown et al., 
unpublished). Snipes were seen 17-29 June 1985 at the Eek River (M. Brown et al., unpublished).

Red-necked phalarope (Phalaropus lobatus). Rspm, Csr, Afm (16 May-15 September). Specimens: RMS1962/36/20, RMS1962/36/19, WFB872, and WFB873.

Red-necked phalaropes nested throughout the study area and were along the coast during spring and fall migration. Flocks of phalaropes were seen in spring 1976 (20 May) when 24 birds were counted in Nanvak Bay (this study) and in May 1987 when flocks of up to 30 birds were at Chagvan Bay (D. F. Parmelee and J. M. Parmelee, unpublished). In fall, small flocks of migrating birds appeared along the coast beginning in mid-July. At Nanvak Bay, a flock of 8 birds in basic plumage was noted on 13 July 1970; flocks totaling 83 birds were seen on 28 July 1970; and in 1976, groups of 44 and 135 birds were noted on 27 July and 28 August, respectively. Smaller flocks were seen most days during fall migration. Few birds were observed in early September and none after 15 September.

We found pairs of phalaropes at the Tuluksak River (DNW photo), the Kisaralik River, llanik Lakes (DNW photo), Cape Peirce, and the Togiak River. Mindell (1983) found birds near Nyac, and Mindell (1983) and B. J. McCaffery (personal communication) found birds at the Kisaralik River. One to five birds were seen at the Eek River on 18-19 June 1985 (M. Brown et al., unpublished). Three birds were seen by White and Boyce (1978) at the Kanektok River in June 1977. P. D. Ameson and D. B. McDonald (personal communication) suspected that phalaropes nested on Crooked Island in June-July 1977, and D. F. Parmelec and J. M. Parmelee (unpublished) suspected they nested at Chagvan Bay. One to four pairs nested each year at the Tuluksak River, and birds nested in the upland tundra plain around the upper Kisaralik River. We collected one female with a well formed egg in her oviduct on 1 June 1962 at the Tuluksak River. We found young on 26 June-27 July at the Tuluksak and Kisaralik rivers, and birds were at those inland breeding areas until 9 August 1962. Along the coast in summer as many as 40 adults used a group of small ponds near Ilanik Lakes. Birds used small ponds near Nanvak Bay beginning 16 May and were seen there throughout the nesting season; two fully feathered young were found on 5 July 1976. Birds were noted in marshy ponds at Chagvan Bay in May 1987 (D. F. Parmelce and J. M. Parmelee, unpublished).

Red phalarope (Phalaropus fulicarius). Uspm, VRsr?, Ufm (16 May-19 September). Specimens: RMS1974/119/21 and YDNWR(CRNWR 96).

Red phalaropes migrated past Cape Peirce and Nanvak Bay each year in spring (16 May-28 June), and molting flocks were there and in 
Goodnews and Chagvan bays in summer (12-23 July). B. Huffmon (personal communication) reported phalaropes nesting at Ilanik Lakes, and we found an alternate-plumaged female at Goodnews Spit on $19 \mathrm{June}$ 1974. Fall migrants occurred along the coast from 7 August and were present until 19 September. We found fall migrants at Nanvak Bay in 1970 and 1973 ( 7 days total both years, one to six birds per day), but not in 1976; at Chagvan Bay in July 1974; and at Goodnews Spit on 14-15 September 1977. D. R. Herter and D. Lloyd (personal communication) found two birds at Cape Peirce on 3 August 1981.

Pomarine jaeger (Stercorarius pomarinus). Rv.

A few pomarine jaegers were seen along the coast in spring, summer, and fall. We found pomarine jaegers at Goodnews Bay (1 on 15 September 1977), Chagvan Bay (1 on 19 July 1974), Cape Peirce (12 on 12 May and 1 on 3 June 1973; 1 on 5 May, 2 on 20 May, 6 on 23 May, and 1 on 1 June 1976), and Togiak Bay (1 on 7 July 1962). A flock of five birds were flying north over Chagvan Bay on 27 May 1987 (D. F. Parmelee and J. M. Parmelee, unpublished). D. R. Herter et al. (personal communication) found pomarine jaegers at Cape Peirce from 6 to 13 June 1984.

Parasitic jaeger (Stercorarius parasiticus). Csr, Av (2 May-12 September).

Parasitic jaegers occurred regularly along the coast-primarily as pairs and singles but occasionally in flocks-and rarely inland. They were seen at Chagvan Bay (D. F. Parmelee and J. M. Parmelee, unpublished), probably nested at llanik Lakes, and nested at Cape Peirce and near the mouth of the Togiak River. One bird was seen inland at the Tuluksak River on 20 July 1978 and another at the hills north of Slug Mountain on 10 July 1973.

At Cape Peirce in 1976, pairs were territorial from 14 May; young fledged by 31 July; families left territories by 3 August; and pairs with young and single adults were seen through fall. In 1973, a pair and a single were near Security Cove on 19 May and 31 August, respectively. Flocks of up to 20 individuals as well as territorial pairs were found along the coast between Goodnews and Chagvan bays in June and July, and groups of up to 30 birds foraged in salmon cannery refuse at the mouth of the Togiak River. We saw jaegers offshore near the Walrus Islands in July 1962; P. D. Arneson and D. B. McDonald (personal communication) saw three light- and one dark-phased jaegers at Crooked Island (20-27 June and 13 July) and two light-phased jaegers at Hagemeister Island ( 9 July) in 1977. Light-phased adults were more common than dark-phased adults near Nanvak Bay $(2.4: 1 ; N=27)$ in 1970 and 1973. Single-phased pairs were more common than mixed-phased pairs (6:2) in 1970 and 1973. 
Long-tailed jaeger (Stercorarius longicaudus). Cv, Rsr (7 May25 August). Specimen: RMS1974/119/02.

We found longtailed jaegers at all coastal locations most years and recorded one inland at the Tuluksak River (Fig. 16) on 8 June 1974. Birds were also at the Kisaralik River on 16-17 June 1987 (B. J. McCaffery, personal communication), at the Kwethluk River on 11 July 1985 (M. Brown et al., unpublished), at the Eek River in August 1976 (R. Baxter, unpublished) and 18-26 June 1985 (M. Brown et al., unpublished), at Kagati Lake on 3 August 1973 J. L. Hout, personal communication), and near Round Island (one bird) on 14 July 1974 (T. J. Eley, unpublished). Jaegers were at Cape Peirce during 15 June-4 July 1981 (D. R. Herter and D. Loyd, personal communication) and 7 June-19 July 1984 (D. R. Herter et al., personal communication). P. D. Arneson and D. B. McDonald (personal communication) suspected that jaegers nested on Hagemeister Island in July 1977; D. F. Parmelee and J. M. Parmelee (unpublished) found birds feeding and roosting (up to five individuals) in Chagvan Bay, and found territorial birds nearby. We found territorial birds, possibly nesting, along the coast between Goodnews and Chagvan bays and near Slug Mountain in dwarf shrub mat habitat. In 1988 (during a local lemming

Fig. 16. Longtailed jaeger above the Tuluksak River, 8 June 1974. Photo by D. N. Weir. 
high) we found three families with fledged or almost fledged young within $1.6 \mathrm{~km}$ of Platinum on 2-5 August.

South polar skua (Catharacta maccormicki). VRv.

One bird was seen by MRP and M. J. Sigman in the marsh near Nanvak Bay on 29 July 1976 after a series of storms in the Bering Sea. The individual was uniformly dark, almost black, and had distinctive white patches at the base of its primaries. While in the area, the skua was mobbed by a parasitic jaeger.

South polar skuas are seen regularly at sea from the Gulf of Alaska to California (American Omithologists' Union 1983), and one has been reported at sea off Icy Cape in northem Alaska (Watson and Divoky 1972).

Bonaparte's gull (Larus philadelphia). Uspm, Uv, Ufm (5 May-22 September).

Bonaparte's gulls used the coastal portions of the study area throughout summer and during spring and fall migrations. We found birds on the coast at Goodnews and Nanvak bays and in the Ahklun Mountains at the Togiak River. Adults and yearlings were at Nanvak Bay during spring migration from 5 May to 3 June 1973 (up to 16 per day, 11 days total). Alternate-plumaged adults were at Goodnews Bay on 19 June 1974. J. G. King (unpublished) found three subadult (or basic-plumaged) birds at Nanvak Bay on 5 July 1964; W. Arvey (personal communication) found several birds there on 5 July 1973, and we observed one on 2 July 1970. Hatching-year birds (MRP photo) arrived at Nanvak Bay beginning on 23 July 1970 and 1976. We found young gulls there between 1 and 22 September 1973, and D. R. Herter and D. Lloyd (personal communication) found gulls there during 21 July-15 August 1981 (seven immatures on 2 August). Few gulls were seen at Nanvak Bay. Small groups and singles were seen every few days in 1973, with 45 birds noted on 18 September. Between 10 and 20 birds were there most days in late July and August 1976. Up to 43 birds foraged for sticklebacks (Gasterosteus spp.) in a small pond near Nanvak Bay on 31 May-3 June and 29-30 July 1976. Both adults and hatching-year birds were at the Togiak River in August 1973. M. J. Fry (unpublished) found an immature bird inland at Kagati Lake on 15 August 1962.

Mew gull (Larus canus). Cspm, Csr, FCfm (28 April-24 September). Specimen: RMS1962/36/22.

Mew gulls used the coastal portions of the study area during spring, summer, and fall, and nested in suitable habitat along the coast and inland. In spring 1973, mew gulls arrived at Nanvak Bay on 28 April and 
120-360 adults gathered at the edge of the ice at the bay entrance from 29 April to 1 May; migration continued until 18 May. Flocks of 30 and 36 adults passed Cape Peirce in $2 \mathrm{~h}$ on 2 May 1973. Subadults appeared on 12 May 1973, and spring movement continued until 18 May 1973. A few singles were seen at Chagvan Bay in late May 1987 (D. F. Parmelee and J. M. Parmelee, unpublished). Fall migration began at Nanvak Bay on 11 August 1970 and by 14 August 1973 . It was predominantly adults that were seen during the latter half of August and hatching-year birds in September. Thirty-five adults were present as late at 22 September 1973.

We found mew gulls nesting in the Kilbuck Mountains at the Salmon River, the Tuluksak River, the Fog River, and the Kisaralik River, and along the coast at Ilanik Lakes, and possibly nesting near Nanvak Bay and the Togiak River. Mindell (1983) found mew gulls to be common in the Nyac area. Mew gulls were also found at the Kisaralik River by $M$. Brown et al. (8-28 August 1985; unpublished) and B. J. McCaffery (16-21 June 1987; personal communication) and at the Kwethluk River by $M$. Brown et al. (13-27 July 1985; unpublished). In the Ahklun Mountains birds were at the Eek River in summer (R. Baxter, unpublished; M. Brown et al., unpublished), nesting at Kagati Lake (M. J. Fry, unpublished); and nesting at the Kanektok River J. L. Hout, personal communication). Mew gulls were common at Round Island in July 1974 (T. J. Eley, unpublished); we found adults and subadults at Nanvak Bay and the Slug River between May and September.

At the Tuluksak River, $0-60$ or more pairs nested along $48 \mathrm{~km}$ of major streams. The largest and most persistent colony (1962-83) was on piles of gravel tailings with porids and channels interspersed throughout the tailings. In 1962, another colony of about 20 pairs nested in white spruces 8-12 $\mathrm{m}$ tall that were in a beaver pond complex. A similar colony of about five pairs was established in spruces in 1975-78. No pairs or nesting birds were found in the Tuluksak River area in 1987. In 1979 , a pair hatched young in an old riparian cliff nest built by golden eagles at the Kisaralik River. The colony at Ilanik Lakes was on small islands in a complex of lakes and ponds in wet and moist tundra habitat.

Birds at the Tuluksak River incubated eggs by 2 June 1962; young fledged 20-28 July; and birds left before 10 August. At the Kisaralik River, we found large downies on 27-28 July 1979. An adult captured sticklebacks in a small pond near Nanvak Bay on 8 July 1976.

\section{Herring gull (Larus argentatus). VRv.}

Hcrring gulls were seen three times at South Spit at Goodnews Bay and once at Cape Peirce. Two adult plumaged-birds were seen at South Spit on 12 June 1974 plus four on 14 September 1977 and one on 17 July 1986. All birds had dark mantles. D. R. Herter et al. (personal 
communication) reported one herring gull at Cape Peirce on 8 June 1984. Light-mantled adult herring gulls were seen just north of our area at Aniak village in 1986 and east of it at Dillingham in 1962.

Slaty-backed gull (Larus schistisagus). VRv.

An adult of this species was seen on 15 June 1984 at Cape Peirce by D. R. Herter et al. (personal communication) and seen and photographed on 12 July 1990 at Shaiak Island (territorial bird; K. Winkler and J. Klicka, unpublished). Slaty-backed gulls have not been previously reported from this area. These sighting are not unexpected, as birds have been reported from the Aleutian Islands, south-coastal Alaska, and Nunivak Island (Kessel and Gibson 1978; American Ornithologists' Union 1983).

Glaucous-winged gull (Larus glaucescens). Asr. (27 April-27 September).

Glaucous-winged gulls occurred throughout the coastal portion of the study area, nested on cliff faces and offshore islands, and fed inland on dead salmon. We found gulls in summer at the refuse dump at Nyac in 1952 and 1962, but not in other years when the dump was smaller. We recorded birds inland at the Kisaralik River on 30 July 1979 and 15 September 1977, at the Salmon and Aniak rivers in July and August 1979 and 1986, and at the Togiak River in August 1973; they were also seen at the Kwethluk River on 21-22 July 1985 (one bird per day; M. Brown et al., unpublished), the Eek River in August 1976 (R. Baxter, unpublished), and Kagati Lake in August 1962 (M. J. Fry, unpublished). Along the coast, birds nested at Little Beluga Peak, Big Beluga Peak (DNW photo), Cape Newenham, Cape Peirce (MRP photo), Shaiak Island (MHD photo; MRP photo) and Nunavachak Lake, and probably nested at Chagvan Bay (D. F. Parmelee and J. M. Parmelee, unpublished). E. H. Miller (unpublished) found one nest on Round Island in 1972; P. D. Arneson and D. B. McDonald (personal communication) also found nesting birds at Round, as well as Summit, Crooked, Twin, High, and Hagemeister islands and Black Rock in 1977. Sowls et al. (1978) reported them nesting on all suitable islands in our study area.

Gulls had arrived at Nanvak Bay by 27 April 1973 and were at nesting territories at Shaiak Island on 2 May 1973 and 1976. At Shaiak Island (Fig. 17), we saw pairs copulating on 19 May 1976 and 27 May 1973; found eggs on 6 June 1976 and 14 June 1973; and saw fledged young on 16 August 1973. A sample of 23 nests contained 1 egg (10 nests), 2 eggs ( 5 nests), and 3 eggs ( 8 nests) on 14 June 1973. Small young were on Shaiak Island on 18 June and fledged young on 25 July 1981 (D. R. Herter and D. Lloyd, personal communication). Nesting success on the island varied between years, with no chicks fledging in 1976 due to fox 


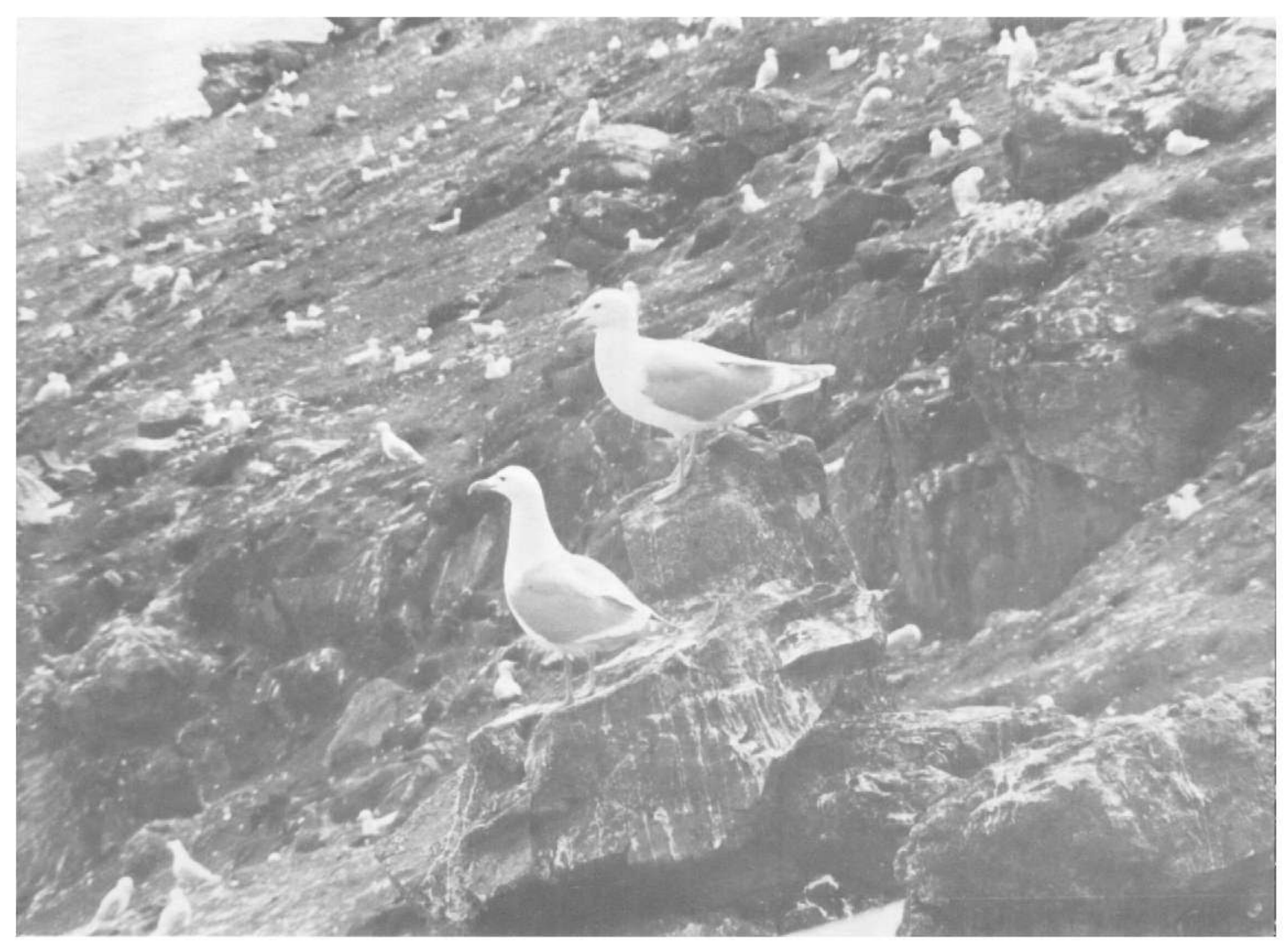

Fig. 17. Glaucous-winged gull colony; Shaiak Island, 14 Junc 1973. Photo by M. H. Dick.

predation (Petersen 1982) and many fledging in other years when no foxes were present. Predation by humans probably occurs regularly. On 14 June 1973, several boats of people from Quinhagak en route to Togiak stopped at Shaiak Island. They gathered (Fig. 18) at least 10 boxes and buckets of eggs, totaling several thousand. An estimated 5,000 glaucouswinged gulls were present on Shaiak Island in 1976, and comparable numbers were present other years. Gulls nested sparsely along the cliffs at Cape Peirce; one nest had a downy young on 10 August 1970.

Foods eaten by adult gulls and fed to their chicks at Shaiak Island included eggs and chicks of other seabirds (especially murres [Uria spp.] and kittiwakes [Rissa spp.]), salmon, sandlance (Ammodytes sp.) and other small fishes, harbor seal (Phoca vitulina) placenta and carcasses, and clams. Hatching year gulls were occasionally seen feeding on berries (Vaccinium spp.) in fall. 


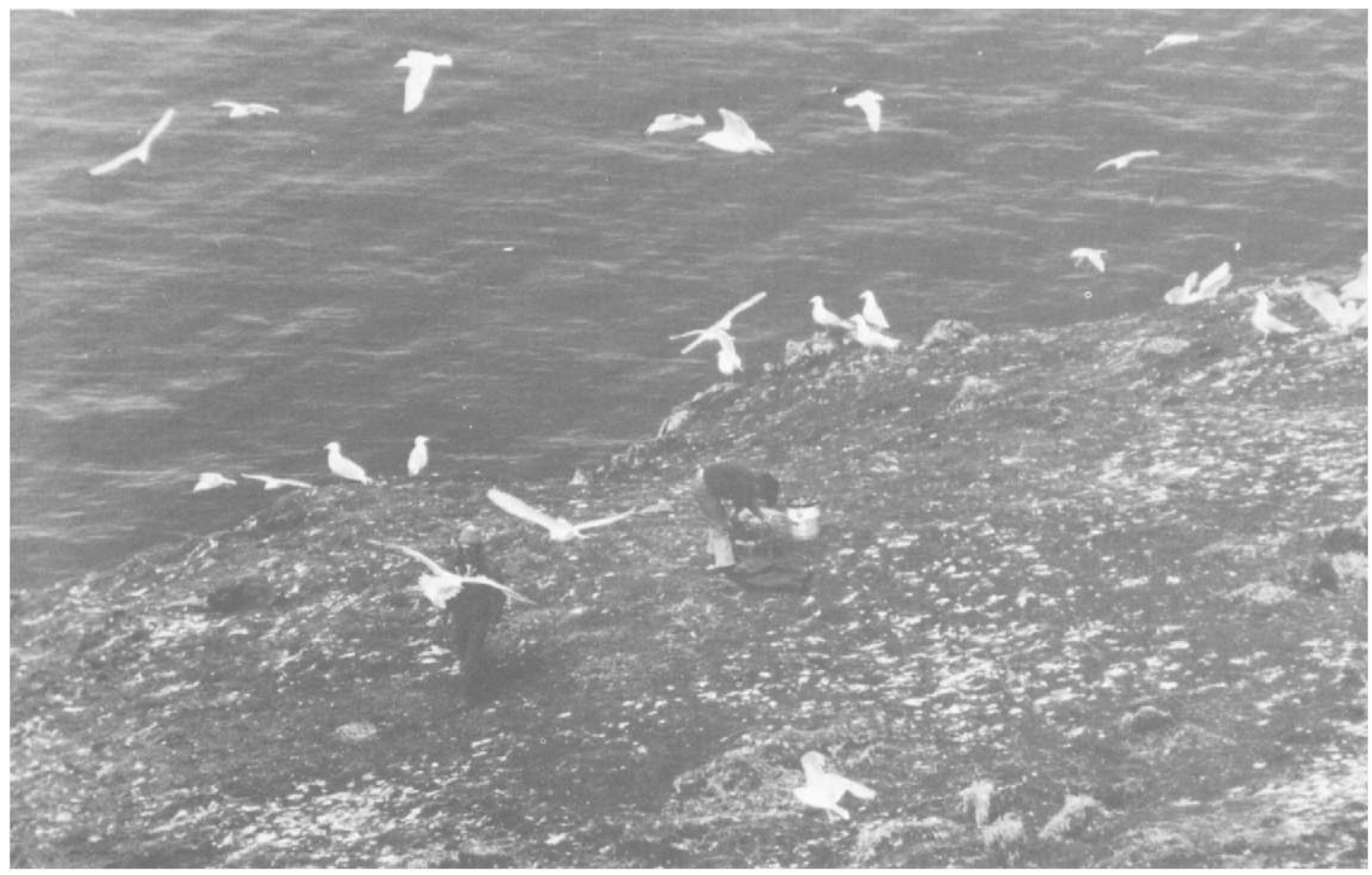

Fig. 18. Gathering gull and eider eggs; Shaiak Island, 14 June 1973. Photo by M. H. Dick.

Glaucous gull (Larus hyperboreus). FCv (1 May-25 September).

Glaucous Gulls were seen on the coast and inland. Subadults (hatching year, yearling, and 2-year-old birds) were at Nanvak Bay on 1-3 May 1973, 16-23 September 1973, and 28 May 1976, at Goodnews and Chagvan bays (DNW photo) in June-July 1974, and at the Togiak cannery in July 1962. One adult was at Cape Peirce on 3 May 1973. In addition, J. L. Hout (personal communication) found two birds at Cape Peirce on 27 June 1970 , and D. R. Herter et al. (personal communication) reported glaucous gulls there on 6 days between 14 June and 16 July 1984. D. F. Parmelee and J. M. Parmelee (unpublished) saw birds at Chagvan Bay on 21 May (one adult, one subadult), 23 May (one subadult), and 27 May 1987 (one subadult). T. J. Eley (unpublished) found a bird at Round Island on 20 July 1974, and P. D. Ameson and D. B. McDonald (personal communication) found second-year-plumaged birds at Black Rock on 18 June (one bird), Twin Island on 19 June (two birds), and Hagemeister Island on 10 July 1977 (three birds). Inland, we found subadult gulls at the Tuluksak River on 25 September 1977. M. Brown et al. (unpublished) 
found gulls at the Kisaralik River on 24 and 28 August and at the Kwethluk River on 10-27 July 1985. White and Boyce (1978) found gulls to be uncommon along the Kanektok River in June 1977, and M. J. Fry (unpublished) found adults at Kagati Lake on 14 August 1962.

Black-legged kittiwake (Rissa tridactyla). Asr (23 April-27 September). Specimens: UAM2620 and YDNWR(MHD 6905).

Kittiwakes nested on cliffs and offshore islands along the coastal portion of the study area. Recent population estimates for the area totaled 381,310 birds (Sowls et al. 1978).

Kittiwakes were present along the coast during an aerial survey on 23 April 1981 (C. P. Dau, unpublished) and had arrived at Cape Peirce by 27 April 1973 and 29 April 1976. Rafts of up to 1,500 birds were present in the waters around Cape Peirce on 27 April 1973; on 2 May, when birds first occupied the cliffs, there was a raft of tens of thousands of birds in the waters near the cliffs. Estimates of hundreds of birds used Chagvan Bay for roosting and feeding in May 1987 (D. F. Parmelee and J. M. Parmelee, unpublished). Kittiwakes at Cape Peirce used dried eelgrass from Nanvak Bay for their nests; in spring, long lines of kittiwakes flew continually from the cliffs to eelgrass drifts and bathing ponds. Nest-building activity began as early as 26 May (Table 4). The first eggs were laid at Cape Peirce on 4 June to 24 June (Table 4). Birds laid eggs to as late as $20 \mathrm{July}$, eggs hatched from early July to early August, and young fledged from late July to early September (Table 4). Of 2,631 pairs in 1976, 789 (30\%) had chicks hatch and $434(16 \%)$ had young fledge; 1 pair fledged 2 chicks and the remainder fledged 1 . Of 136 pairs sampled on 21 August 1977 , none had young nor were any fledged young seen in the area. Nesting failures occurred in 4 of 11 years at Cape Pcirce (Table 5). At Bird Rock, J. L. Hout (personal communication) found pairs with eggs and chicks on 26 July 1969 . At Round Island, some chicks were in nests on 9 July 1962.

In summer, flocks of kittiwakes bathed in freshwater ponds near Nanvak Bay and on Cape Newenham, and groups of 10 to $\geq 100$ birds were found in June bathing in ponds from Goodnews Bay south along the coast. On 25 June 1977, about 7,500 kittiwakes bathed in a brackish lagoon on Crooked Island (Arneson 1977). In 1973, hundreds of kittiwakes were still present on nesting cliffs at Cape Newenham on 24 September, although many birds had left the colonies. On 25 September, a few kittiwakes remained at Cape Peirce, and small flocks were at Nanvak Bay until our departure on 27 September; two specimens were collected there in 1969.

Foods from 10 adults included copepods (30\% of birds), mysid (30\%), unidentified fish (10\%), walleye pollock (Theragra chalcogramma;10\%), and sandlance (80\%); and 10 chick regurgitations contained copepods (20\% of samples), mysid (20\%), and sandlance (100\%; Lloyd 1985 ). 


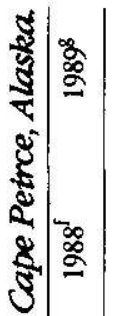

芦芯

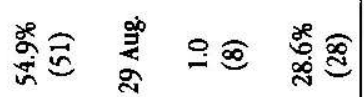

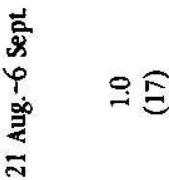

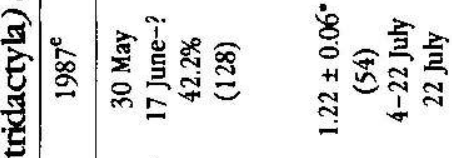

$\stackrel{\circ}{0}$

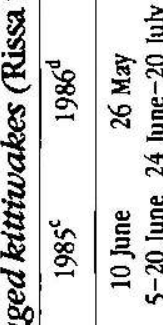

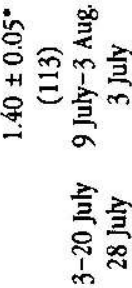

$\frac{\pi}{2}$

亭

8

然 
Tablc 5. Reproductive success of black-legged kittiuakes (Rissa tridactyla) at Cape Peirce, Alaska.

\begin{tabular}{lcc}
\hline Year & $\begin{array}{c}\text { Percent of fledglings per } \\
\text { number of attempted nexts }\end{array}$ & Number of nests sampled \\
\hline 1970 & $15.0 \%$ & 60 \\
1973 & $9.0 \%$ & 190 \\
1976 & $16.5 \%$ & 2,631 \\
1977 & $0.0 \%$ & 136 \\
$1981^{2}$ & $15.6 \%$ & 308 \\
$1984^{\mathrm{b}}$ & $0.4 \%$ & 275 \\
$1985^{\mathrm{c}}$ & $0.4 \%$ & 260 \\
$1986^{\mathrm{d}}$ & $0.0 \%$ & 300 \\
$1987^{\mathrm{e}}$ & $6.2 \%$ & 128 \\
$1988^{\mathrm{f}}$ & $15.6 \%$ & 109 \\
$1989^{8}$ & $6.4 \%$ & 124 \\
\hline
\end{tabular}

"Loyd 1985.

${ }^{b}$ Johnson 1985.

D. R. Herter and B. Higgins, unpublished.

${ }^{d}{ }_{L}$. van Hulsteyn and $K$. Kavanaugh, unpublished.

${ }^{c} \mathrm{~L}$. Haggblom and $\mathrm{A}$. O' Neil, unpublished.

f D. L. O'Daniel, unpublished.

${ }^{8}$ l. Haggblom, unpublished.

Red-legged kittiwake (Rissa brevirostris). VRv.

We saw this species twice in 1976. On 30 April, four adults roosted on some ice in Nanvak Bay, and on 2 September, a hatching-year bird roosted on some rocks at Cape Peirce. Arneson (1977) saw one bird roosting on the beach rocks at High Island on 11 July 1977. Gabrielson and Lincoln (1959) reported that "a number circled about the boat as it passed Cape Newenham on July 12" 1946.

Sabine's gull (Xema sabini). Rv, Rst?

Sabine's gulls occurred at coastal locations on the study area. We found Sabine's gulls on South Spit at Goodnews Bay on 13 and 19 June 1974 and 16 July 1986 and at Nanvak Bay during 5 days between 12 and 31 May 1976. J. G. King (unpublished) saw a few birds at Nanvak Bay on 5 July 1974. Three birds were seen swimming in Chagvan Bay on 27 May 1987 (D. F. Parmelce and J. M. Parmelee, unpublished). B. Huffmon (personal communication) reported them nesting at Ilanik Lakes, although we found none nesting there in June 1974.

Arctic tern (Sterna paradisaea). Asr (12 May-15 September). Specimen: RMS1962/36/23.

Arctic terns nested in suitable habitats on the coast and inland, and foraged in streams, lakes, estuaries, and inshore waters. Terns nested at 
the Salmon River, the Tuluksak River (DNW photo), near Nyac (Mindell 1983), the Fog River, the Kisaralik River, the Kanektok River, Goodnews Bay (DNW photo), Ilanik Lakes, Chagvan Bay (this study; D. F. Parmelee and J. M. Parmelee, unpublished), the Slug River, and the Togiak River, and probably nested at the Kwethluk River, the Goodnews River, and the Arolik River. Terns also nested at Kagati Lake (M. J. Fry, unpublished), were common along the Kanektok River (White and Boyce 1978), and probably nested at Hagemeister Island (Arneson 1977).

Inland at the Tuluksak River, the number of terns varied from 7 to 70 pairs over 6 years along $48 \mathrm{~km}$ of major streams and averaged 3.3 pairs per square kilometer in riparian habitats in 1983. At the Tuluksak River and along other rivers, pairs or groups of pairs nested primarily at braided sections or fast flowing, rocky sections of clear streams, usually just below the foothills. On the coast, a colony of about 500 pairs has persisted at south Goodnews Spit since at least 1933. Another colony at north Chagvan Spit had about 100 pairs nesting in 1974 but apparently none in 1986; most coastal colonies had fewer than 10 pairs.

Nest sites found inland were primarily in unvegetated gravel or tailings along streams; on bare ground or in short vegetation near lakes; on islands and shores of ponds; occasionally on muddy gravel areas in beaver pond complexes; once on the roof of a beaver house, and once in an old tree nest of a mew gull. At the Tuluksak River in 1962, one arctic tern nest had pipped eggs on $1 \mathrm{July}$, and some young fledged before the end of July; in 1974, large downies were present on 22 June, and the first young fledged on $13 \mathrm{July}$; in 1976, some pairs had large downies on $22 \mathrm{July}$; in 1978 , young had fledged by $20 \mathrm{July}$. In all years at the Tuluksak River, terns were gone by 5-10 August. At the upper Kisaralik River, birds were present on 16 June 1987 (B. J. McCaffery, personal communication), some pairs had large downy young on 27-28 July 1979 (this study), and birds were present during 10-18 August 1985 (M. Brown et al., unpublished). At the Togiak River, young had fledged by 3-9 August 1973 , but were still being fed by adults. Birds were found at the Kwethluk River on 10-26 July 1985 and the Eek River on 17-27 June 1985 (M. Brown et al, unpublished).

On the coast, most tern colonies were on sand or gravel spits, and most nests were located between the high water line and storm line on unvegetated beach, in short discontinuous vegetation, or in dry dwarf shrub mat. A nest with one egg was found on a low, dry ridge on 27 May 1987 at Chagvan Bay (D. F. Parmelee and J. M. Parmelee, unpublished). Actual nesting chronology at South Goodnews Spit was difficult to determine because of egg gathering by the people living there. On 13 June 1974, 9 of 140 scrapes had eggs ( 6 nests with 2 eggs and 3 nests with 3 eggs); by 17-19 June most pairs were incubating; and on 17 July some nests had pipping eggs and newly hatched young while other pairs 
had large downies to recently fledged young. At north Chagvan Spit, all young were flying or within a week of flying on 19 July 1974. Terns were still present at Goodnews Bay between 12 and 15 September 1977.

\section{Aleutian tern (Sterna aleutica). Csr (5 June-23 July).}

Aleutian terns nested along the coast and were occasionally seen inland. We found a large colony of Aleutian Terns each year at south Goodnews Spit (DNW photo). Pairs or single adults were seen in coastal areas at Chagvan Bay (possibly nesting before 1952; B. Huffmon, personal communication), Nanvak Bay (this study), and Hagemeister Island ("likely" nesting; Arneson 1977). Two pairs were seen at Hagemeister Strait on 5 July 1970 by Gibson (Kessel and Gibson 1978) and one bird was seen flying near Round Island (T. J. Eley, unpublished). Inland, J. L. Hout (personal communication) saw one bird at the Kanektok River.

The colony at Goodnews Bay expanded, from 60 to 75 pairs in 1933 (Bull in Friedmann 1933) to at least 250 pairs in 1974. It was much larger in 1980 , but was reported by B. Huffmon (personal communication) to be down to fewer than 10 pairs in 1984; there were probably more than 200 pairs in 1986 and 300 pairs in 1988. We found nests in dwarf shrub mat and grass meadow habitats. Young moved to grass-heath meadows near their nests soon after they hatched and to grass meadows as they grew.

As with arctic terns, nesting chronology of Aleutian terns at Goodnews Bay was difficult to determine because of egg gathering by local people. In 1974, eggs were found by local people from 5 June; some nests had one or two eggs on 19 June (unknown if first or second clutches); no eggs were seen and adults were feeding young on 17 July; young ranged from downy to fully feathered stages on 17-19 July, and most chicks seen (about 10) were almost flying on 23 July. Adults wcre fecding young at downy stages and partly feathered young on 4 August 1988; no fledged young were present. Of about 50 or so adults seen bringing food to chicks in 1974 and 1986 , about $80 \%$ brought sandlances. Fggs and chicks were taken by common ravens, dogs, jacgers, and foxes (B. I Iuffmon, personal communication).

Common murre (Uria aalge). Asr (27 April-3 Scptember). Specimens: UAM2618, YDNWR(CRNWR 113), and YDNWR(CRNWR 114).

Murres (Fig. 19) nested on mainland cliffs and islands along the coastal portion of the study area from Bird Rock near Cape Newenham to Round Island. Sowls et al. (1978) estimated that more than $1,036,000$ murres nested in the study area, but accurate estimates are extremely difficult. Most murres reported in Sowls et al. (1978) nested at Bird Rock, Cape Newenham, Cape Peirce (two MHD specimens; MIID photo; MRP 


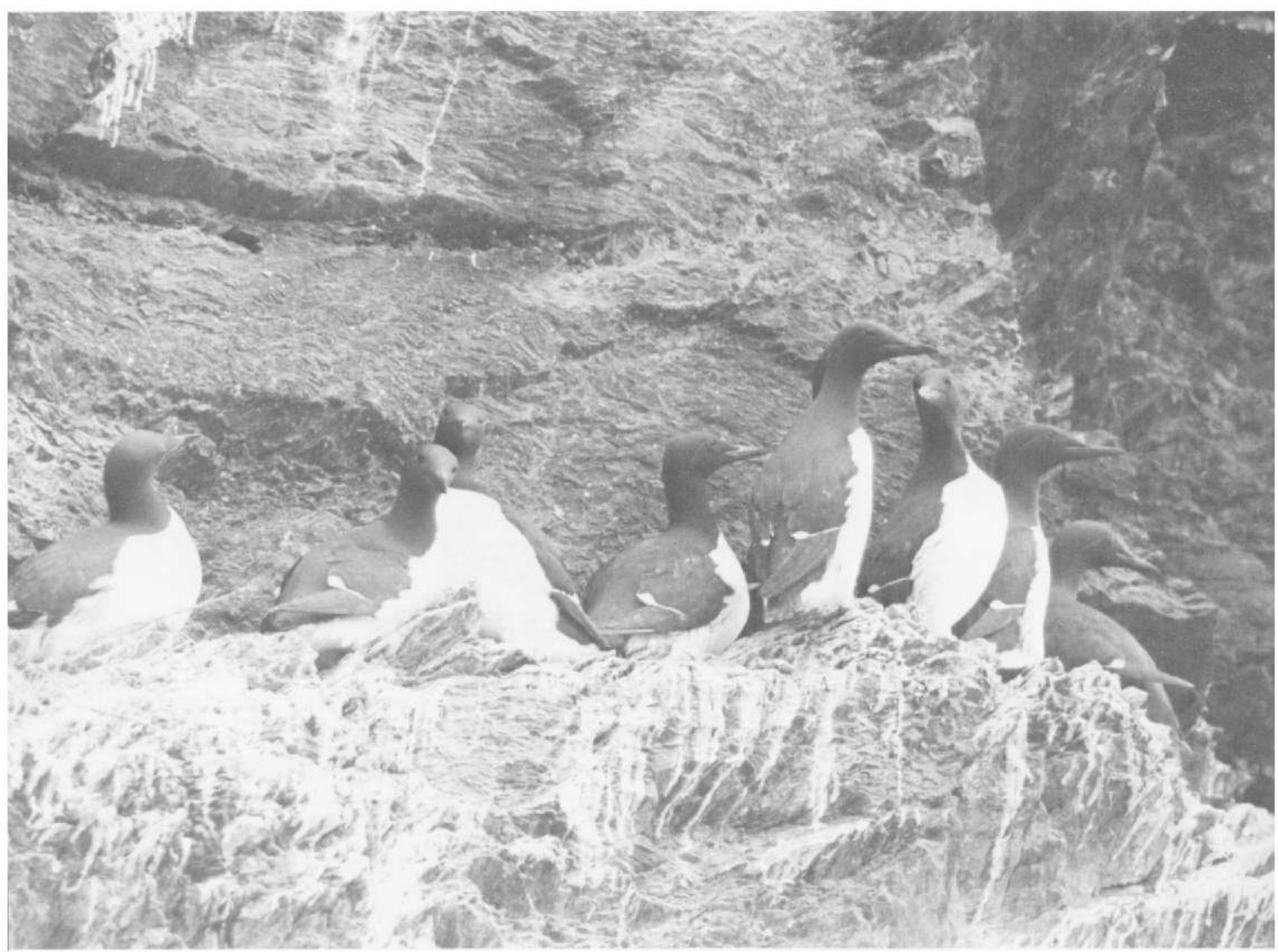

Fig. 19. Common murres on nesting ledge typical of those found along coastal cliffs and islands, 1973. Photo by M. H. Dick.

photo), Shaiak Island (MHD photo; MRP photo), High Island, Twin Islands, Black Rock, and Round Island.

In spring at Cape Peirce, murres intermittently occupied the cliffs from their arrival in late April until egg laying began in June. In 1973, tens of thousands of murres occupied the cliffs and rafted on inshore waters on 27 April, 2 May, 5-6 May, and 11 May but were virtually absent in the intervening days; their presence was irregular until about 6 June. In 1976, adults were on the colonies by 28 April and occupied the cliffs irregularly until 12 June. Egg laying began between 5 and $14 \mathrm{June}$ in 8 years between 1969 and 1986 (Table 6). Young hatched between 2 July and 1 August or later and fledged (jumped from cliffs) as early as 25 July (Table 6). At Bird Rock, J. L. Hout (personal communication) found eggs and chicks on 26 July 1969. At Round Island, some freshly broken eggs had half-grown embryos on 9 July 1962. 


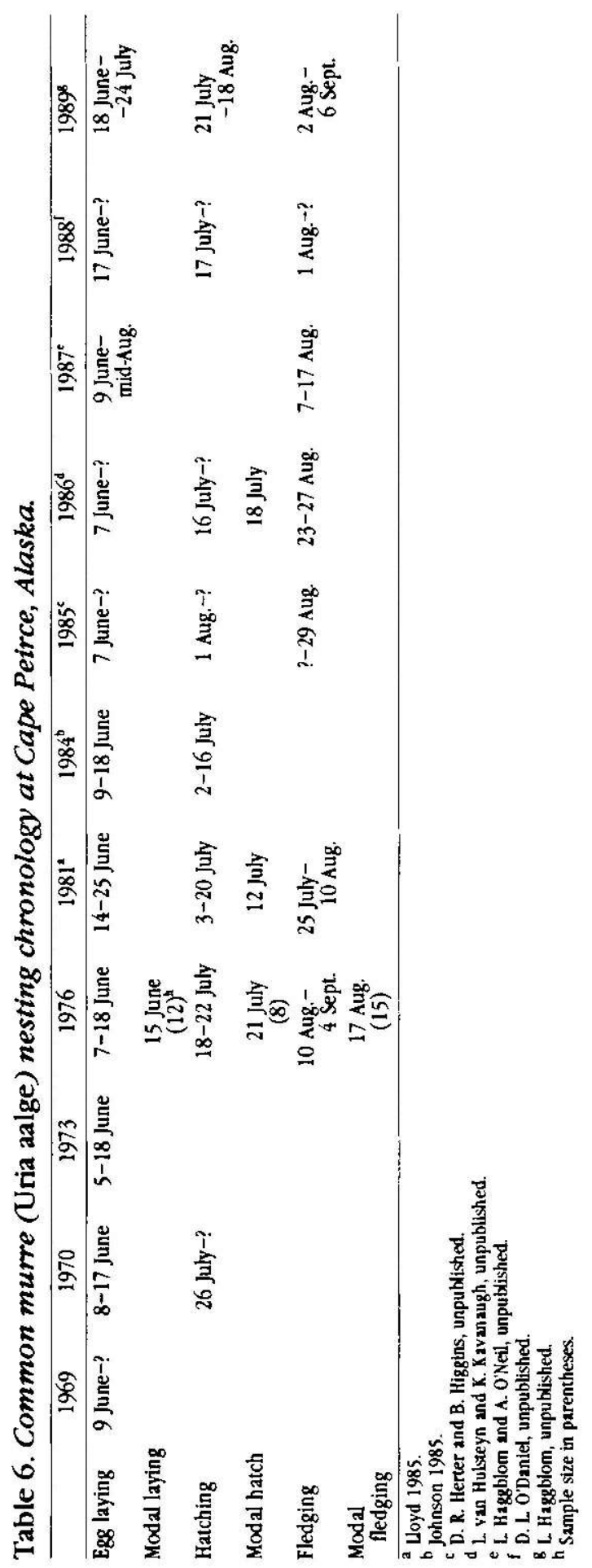


Five murres collected at Cape Peirce in 1976 had eaten sandlances and unidentified fishes. Five murres collected there in 1981 had eaten copepods ( $80 \%$ of birds), mysid ( $40 \%$ ), decapod ( $20 \%$ ), gammarid (20\%), rainbow smelt (Osmerus mordax dentex; $20 \%$ ), and sandlance $(80 \%$; Lloyd 1985).

\section{Thick-billed murre (Uria lomvia). VRv.}

One dead thick-billed murre was found on the beach at Chagvan Bay on 17 July 1986. A very few were tentatively identified as thick-billed murres at Round Island on 9 July 1962 by DNW, but T. J. Eley (unpublished), R. MacIntosh (unpublished), and Arneson (1977) saw none there in later years.

Pigeon guillemot (Cepphus columba). Csr (27 April-22 September). Specimens: UAM2621 and WFB867.

Guillemots probably nested along the coastal portion of the study area in all suitable habitats from Goodnews Bay to the Walrus Islands, although we found nests only at Cape Peirce and Shaiak Island. Recent population estimates for the study area totaled 1,601 birds (Sowls et al. 1978; plus 10 pairs at Beluga Peak). Birds were present when we arrived at Cape Peirce on 27 April 1973, and the first birds were seen on 1 May 1976. They were present intermittently until 11 May 1973 and 12 May 1976. Pairs were commonly seen in the water before their return to the cliffs. We found alternate-plumaged birds in summer near rock cliffs and boulder piles at Beluga Peak, along the shore near Chagvan Bay, and at Cape Peirce, Shaiak Island, Hagemeister Island, High Island, Twin Islands, Black Rock, and Round Island. Arneson (1977) also found guillemots ubiquitous throughout the Walrus Islands and Hagemeister Island in 1977. R. MacIntosh (unpublished) thought they nested at Round Island in June 1976. Nest sites were in crevices between large rocks and boulders above the high tide line. D. R. Herter and D. Hoyd (personal communication) found a nest with one egg and one chick on 13 July 1981 at Shaiak Island. Fledged young were first seen on 16 August (1973) and 13 August (1976) at Cape Peirce.

One subadult bird at Cape Peirce had eaten small invertebrates (Dermaturus mandtii and Spiroutocaris arcuata), and an adult had eaten hermit crabs (Pagurus spp.) and unidentified fishes. Unlike other alcids, guillemots foraged at the mouths of Goodnews, Chagvan, and Nanvak bays.

\section{Marbled murrelet (Brachyramphus marmoratus). VRv.}

We watched a single bird dive near Shaiak Island on 7 August 1970. J. L. Hout (unpublished) saw a bird in Nanvak Bay in September 1971. 
Marbled murrelets were also found about $64 \mathrm{~km}$ south of Hagemeister Island in Bristol Bay on 10 August 1969 (Bartonek and Gibson 1972).

Kittlitz's murrelet (Brachyramphus brevirostris). VRv.

An alternate-plumaged female was taken by Bull (in Friedmann 1934) near Goodnews Bay on 21 June 1933.

Parakeet auklet (Cyclorrhynchus psittacula). Csr (6 May-2 September). Specimens: WFB870, WFB871, and YDNWR(CRNWR 357).

Parakeet auklets were found along coastal portions of the study area. Birds nested at Round, Crooked, Twin, High, and Hagemeister islands but were most common at Round and Iligh islands (Arneson 1977). They probably nested at Cape Newenham, Cape Peirce, and Shaiak Island (Sowls et al. 1978). They were seen near Bird Rock by J. L. Hout (personal communication), and P. D. Ameson and D. B. McDonald (personal communication) suspected that they nested at Black Rock. These auklets were at Cape Peirce on 5 July 1964 O. G. King, unpublished), and all subsequent observers have found them there. We found auklets displaying on the water and in the air near cliffs at Cape Peirce beginning 11 May 1973 and 6 May 1976; flying into and from crevices beginning 28 May 1970 and 12 June 1976; and gone from the cliffs by 12 August 1976 . Adults with brood patches were collected near Shaiak Island on 14 July 1976. We recorded birds at Cape Peirce until 15 July 1970, 15 August 1973, and 2 September 1976. D. R. Herter and D. Lloyd (personal communication) reported birds present until 2 August 1981. Adults and young were on the water at Round Island on 14-23 July 1974 (T. J. Eley, unpublished).

Least auklet (Aethia pusilla). VRsr?

T. J. Eley (unpublished) saw three adults and two fledged young in the water near Round Island on 17 July 1974. This species was not seen there in 1962 by DNW, nor were colonies recorded elsewhere in the study area (Sowls et al. 1978).

\section{Crested auklet (Aethia cristatella). Rsr.}

The population on the study area is estimated to be about 100 birds, all on Round Island (P. D. Arneson and D. B. McDonald in Sowls et al. 1978). No birds were seen there on 9 July 1962 by DNW. One bird was seen by E. H. Miller (unpublished) on 11 June 1972; adults with young were at the island on 14-23 July 1974 (T. J. Eley, unpublished); and one bird was seen in the water next to the island on 27 June 1976 (R. MacIntosh, unpublished). 
Rhinoceros auklet (Cerorhinca monocerata). VRv.

A single alternate plumaged bird was seen near Round Island on 4July 1977 (Ameson 1977). Although seen in the Aleutian Islands (American Ornithologists' Union 1983), most records of rhinoceros auklets in Alaska are south of the Alaska Peninsula (Gabrielson and Lincoln 1959).

Tufted puffin (Fratercula cirrhata). Asr (11 May-8 September). Specimen: WFB686.

Tufted puffins (Fig. 20) nested in burrows (MHD photo; MRP photo) or crevices in cliffs along the coast and on offshore islands in areas generally inaccessible to foxes. Estimates as reported in Sowls et al. (1978) totaled 87,410 tufted puffins on the study area. Within the Walrus Islands, tufted puffins were most common on Twin Islands although found on each island (Arneson 1977).

At Shaiak Island, $305 \times 5$-m plots averaged 0.4 active burrows per square meter ( $\mathrm{SE}=0.04 ;$ range, $0-1.25$ ). The first young in 1976 was found there on $17 \mathrm{July}$, and most eggs had hatched by 4 August. D. R. Herter and D. Lloyd (personal communication) found newly hatched chicks there on 13 and 25 July 1981 . Of the 62 puffin nests that we monitored from the

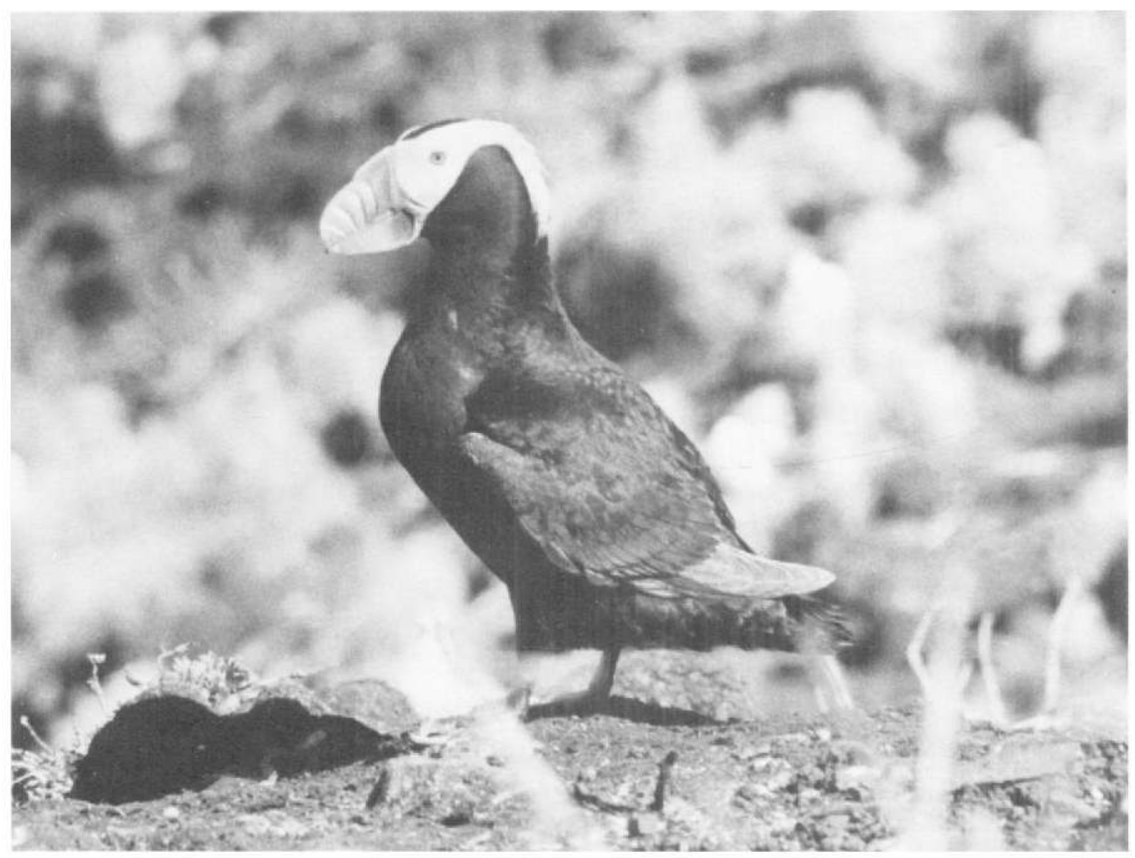

Fig. 20. Tufted puffin; Shaiak Island, July 1976. Photo by M. R. Petersen. 
start of laying in 1976, 21 (34\%) lost eggs or young: 5 nests were dug out by red foxes, eggs disappeared from 11 nests, and 5 nests were deserted.

Ten adults collected 19 June-22 August 1976 had eaten crustaceans, capelin (Mallotus villosus), sandlances, red Irish lords (Hemilepidotus hemilepidotus), and unidentified fishes.

Horned puffin (Fratercula corniculata). Csr (16 May-8 September). Specimens: WFB865, WFB866, and YDNWR(CRNWR 115).

Horned puffins nested in the coastal portion of the study area in rock crevices in cliffs (Fig. 21) and in boulder piles along the shore above the high tide line. Sowls et al. (1978) estimated more than 4,000 birds in the study area, all on rocky shores and islands south of Chagvan Bay. In

Fig. 21. Horned puffin on its nest in a crack on a cliff; Cape Peirce, 25 July 1976. Photo by M. R. Petersen.

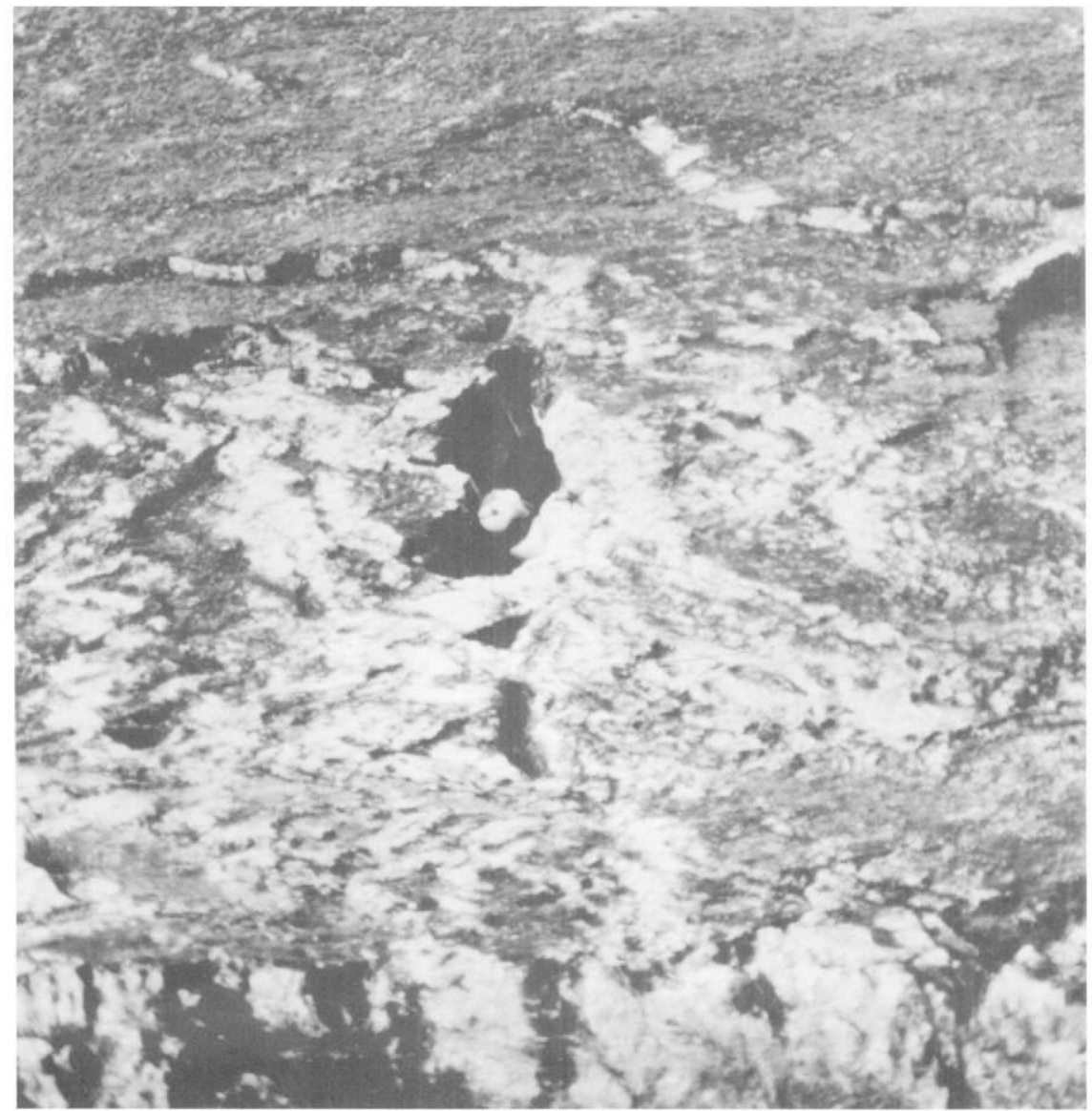


addition, we saw about 10 birds entering holes at Little Beluga and about 50 birds at Big Beluga Peak in Goodnews Bay in June 1974; J. L. Hout (personal communication) reported horned puffins on Bird Rock near Cape Newenham. Within the Walrus Islands, horned puffins were most plentiful on Round Island (Ameson 1977), and an adult was collected there on 19 August 1960 by C. J. Lensink (personal communication).

At Cape Peirce, birds arrived on 18 May 1973 and 16 May 1976. Eggs were found on 7 July 1976, a bird in incubation posture was seen on 12 June 1973, a chick was seen on 3 August 1970, and adults were present until 8 September 1973 and 1976. Adults collected there in 1976 had brood patches.

Great horned owl (Bubo virginianus). Cpr. Specimen: RMS1962/$36 / 24$.

Great horned owls nested in the Kilbuck Mountains each year and were reported by $\mathrm{C}$. Awe and J. Bloomquist (personal communication) to occur there throughout winter. We found nests or fledged young at the Salmon River, the Tuluksak River (downies; DNW photo), and the Kisaralik River. Owls were also observed at the Kisaralik River on 21 June 1987 (B. J. McCaffery, personal communication). One owl was seen on 28 July 1985 at the Kwethluk River (M. Brown et al., unpublished). Nesting territories were generally in riparian spruce-cottonwood or the edge of riparian spruce-cottonwood and spruce forests $30-280 \mathrm{~m}$ asl.

Seven centers of nesting territories were about $5.5 \mathrm{~km}(4.7-6.3 \mathrm{~km})$ apart at the Tuluksak River, and three families with fledged young were seen along $38 \mathrm{~km}$ of the middle and lower Kisaralik River in July 1979. Nests were on the ground and to $8 \mathrm{~m}$ above the ground, and they were located inside an old dredge (one), at the base of a tree on a cliff face (one), in hollow tops of old poplar stubs (two), and in old raptor or raven nests in poplar trees (two).

In 6 years on the Tuluksak River, we found $1.92 \pm 0.88$ pairs per year; broods with large, fledged young averaged $1.50 \pm 0.72$ young per nest. One nest had eggs in mid-March, four pairs had young fledge between 25 June and 5 July, and four broods were flying well on 1-15 July. Breeding success was uncertain but probably high (one site had young fledge 6 of 7 years). No young were found on the Tuluksak River in 1983 after the 1982 snowshoe hare population crash.

Great homed owls at the Tuluksak River were highly selective predators of hares, larger microtines, and larger birds (Weir and Hanson 1989). Nineteen fresh food items at nests or seen being taken to young included 10 juvenile snowshoe hares, 1 adult spruce grouse, 1 adult willow ptarmigan, 1 juvenile pintail, 1 large shorebird, 1 swallow, 2 small passerines, 1 dolly varden (Salvelinus malma), and 1 arctic grayling (Thymallus arcticus). Food items in pellets collected near a nest during July 1974 
(Weir and Hanson 1989) included 14 snowshoe hares, 3 Greenland collared lemmings (Dicrostonyx groenlandicus), 4 northern bog lemmings (Synaptomys borealis), 11 brown lemmings (Lemmus sibiricus), 12 northern red-backed voles (Clethrionomys rutilus), 2 muskrats (Ondatra zibethica), 18 tundra voles (Microtus oeconomus), 10 singing voles (M. miurus), 8 meadow voles (M. pennsylvanicus), 3 least weasels (Mustela nivalis), 14 birds, and 2 fishes.

\section{Snowy owl (Nyctea scandiaca). Rspm, Rsr, Rfm.}

Snowy owls have occasionally been reported in the Kilbuck Mountains at the Tuluksak River and along the coast at Goodnews and Chagvan bays. About five pairs nested between Goodnews and Chagvan bays in 1973 during a lemming population high (various Platinum miners, personal communication), but we saw none there in 1974 or in 1988 , also during lemming peaks. Single birds migrated through the Tuluksak River area from mid-August to mid-October during most years (C. Awe, C. Clark, Jr., J. Bloomquist, personal communication) and a pair was seen there in spring 1987 (C. Clark, Jr., personal communication).

Northern hawk-owl (Surnia ulula). Usr, Rv (6 June-30 Scptember).

Hawk-owls nested in the Kilbuck Mountains. We found them at the Tuluksak River (DNW photo) and C. Clark, Jr. (personal communication) found them at the Salmon and Kisaralik rivers. Territories at the Tuluksak River were at the edges of spruce or riparian woods and dwarf shrub mat on river terraces $140-230 \mathrm{~m}$ asl. We found four breeding territories in $48 \mathrm{~km}$ of major streams irregularly occupied throughout 10 years of observations; 1.4 pairs per year were found in 8 years. Spacing of the centers of territories there was regular, with a range of $5.3-6.1 \mathrm{~km}$ and a mean of $5.6 \mathrm{~km}$ between them. One nest was in riparian spruce-cottonwood habitat in a cavity $0.6 \mathrm{~m}$ deep in the hollow top of a spruce stub $7.5 \mathrm{~m}$ tall and $0.3 \mathrm{~m}$ in diameter. Four pairs fledged two to three young each. Young of three pairs fledged about 16 July 1976 , about 20 July 1978 , and about 20 July 1983. Young were independent on 30 August 1952 and 11 August 1977. One young was still present on 20 September 1977.

Great gray owl (Strix nebulosa). Rsr.

In the Kilbuck Mountains, we found owls nesting at the Tuluksak (two locations) and Kisaralik rivers (one location), and R. Baxter (unpublished) saw a bird at the Eek River on 6 August 1976. All were in riparian spruce-cottonwood habitats $45-150 \mathrm{~m}$ asl. A stick nest high in a spruce tree at the Tuluksak River had a bird on an egg on 15 March 1960 (C. Clark, Sr., personal communication). We saw adults feeding a fledged 
young in August 1952 at the Tuluksak River and in July 1979 at the Kisaralik River.

Short-eared owl (Asio flammeus). Rsr, Rfm.

Owls migrated in fall and probably nested along the coast in most years. At Cape Peirce, a flightless young was found on 2 July 1981 (D. Lloyd and D. R. Herter, personal communication). Nesting birds were reported by Platinum miners at Goodnews and Chagvan bays in 1973 during a lemming population high, and we found a family with three newly fledged young there on 2-5 August 1988, also during a lemming high. Single birds and a territorial bird were in Chagvan Bay in May 1987 (D. F. Parmelee and J. M. Parmelee, unpublished). J. L. Hout (personal communication) found a bird at Goodnews Spit on 28 July and two at Cape Peirce in June 1969. Owls were in nesting habitat at Cape Peirce from 28 April to 6 Junc 1973; an owl was flushed from tall grass $0.5 \mathrm{~km}$ inland from Nanvak Bay on 10 July. No nest was found, but there were pellets in the area and the birds seemed territorial. Owls were seen almost daily during summer 1981 near Nanvak Bay (D. R. Herter and D. Lloyd, personal communication), but only sporadically ( 3 days) between 12 June and 15 July 1984 (D. R. Herter et al., personal communication). Inland, J. L. Hout (personal communication) found a bird on 4 August 1973 at the Kanektok River. In fall, we found birds at the Togiak River from 3 to 9 August 1973 and at Cape Newenham and Cape Peirce from 3 to 31 August.

Boreal owl (Aegolius funereus). Rpr.

Boreal owls nested in the Kilbuck Mountains and occurred on the coast. We found owls throughout the year at the Tuluksak River J. Durst, photo). Young fledged there at three locations in early July at riparian spruce-cottonwood habitats and spruce forest on terraces. They were also reported at the Salmon River (C. Awe and J. Bloomquist, personal communication). Along the coast, one was collected by Bull (in Friedmann 1933) at Goodncws Bay on 26 January 1933.

Rufous hummingbird (Selasphorus rufus). VRv.

Hummingbirds were observed five times, both inland and on the coast. In late June 1961, a male rufous hummingbird was seen in a riparian secondary woodland clearing near the Tuluksak River (C. Clark, Sr., personal communication). On 30 July 1981 and 20 July 1983, single hummingbirds were reported in a clearing in secondary woodland near the Tuluksak River (C. Awe, personal communication). Mindell (1983) also reported a hummingbird near Nyac on 15 July 1980. D. R. Herter and D. Lloyd (personal communication) saw a female rufous hummingbird at 
Cape Peirce on 10 August 1981. A hummingbird was reported just outside our area at Kwethluk Village in 1955 (Kessel and Gibson 1978). Rufous hummingbirds are rarely observed along the Alaskan coast north of the Alaska Peninsula; there are no previous records for our study area (Kessel and Gibson 1978).

Belted kingfisher (Ceryle alcyon). Csr (29 May-26 August). Specimen: RMS1962/36/25.

Kingfishers nested in the northern Kilbuck Mountains and were occasionally found elsewhere. They nested each year at the Tuluksak River and reportedly at the Salmon River (C. Awe, personal communication); Mindell (1983) reported them as an uncommon nesting bird near Nyac; we saw them at the Aniak River, and they were seen at the Kisaralik River (25 August 1985; M. Brown et al., unpublished), the Eek River (R. Baxter, unpublished), and the Goodnews River (B. Huffmon, personal communication).

We found $2.6 \pm 0.51$ pairs per year (zero to five nests) in 8 years at the Tuluksak River along $\mathbf{4 8} \mathrm{km}$ of major streams within the foothills to $250 \mathrm{~m}$ asl. Birds fished in fluviatile waters. Six nests were about 1-30 m from water and 2-6 $\mathrm{m}$ above the water in cutbanks of fine soil. One nest had eggs on 2 June 1962. Young were in nests between 22 July and 12 August 1962, 6-13 July 1971, 3-26 July 1976, and on 4 July 1983. Young had fledged by 12 August 1962 and 9 July 1979 and were still in the area until 26 August 1974. Remains of a bird were found at a gyrfalcon nest on 9 July 1987.

\section{Downy woodpecker (Picoides pubescens). Upr.}

Downy woodpeckers were regular visitors to bird feeders near Nyac in winter (H. Svensen, personal communication) and nested at the Tuluksak River. In 1985, M. Brown et al. (unpublished) found them at the Kwethluk River on 23 July (one to five birds) and 24 July (one bird). We also saw them at the Salmon and Aniak rivers between 26 July and 1 August 1986. One nest at the Tuluksak River had young on 1 July 1978 and was in a hole $3 \mathrm{~m}$ above the ground in a spruce stub $4.5 \mathrm{~m}$ tall. The spruce was among willows ( $3 \mathrm{~m}$ tall) within riparian poplar habitat. We saw an adult carrying food and heard young in similar habitat on 7 July 1981. J. Birch (personal communication) saw an adult female there between 28 July and 5 August 1981 . We found three recently fledged broods on 5-9 July 1983 along $5 \mathrm{~km}$ of riparian spruce-poplar, and 2.9 pairs per square kilometer in undisturbed plots. None were found in disturbed plots. Woodpeckers were seen at four to six locations per week in secondary woodland or tall alder shrub habitats in fall (20 September7 November). All birds were in main valley floors $90-225 \mathrm{~m}$ asl. 
Hairy woodpecker (Picoides villosus). VRpr.

Hairy woodpeckers used bird feeders near Nyac in winter (H. Svensen, personal communication). We saw a bird at the spruce woodland and dwarf shrub mat habitat edge at the Tuluksak River on 27 August 1974 and another on 7 October 1977.

Three-toed woodpecker (Picoides tridactylus). Upr. Specimen: BMNH/83sk/DNW06.

This woodpecker was found in the Kilbuck Mountains. B. J. McCaffery (personal communication) found a bird on 21 June 1987 at the Kisaralik River. A single bird was seen at the Kwethluk River on 26 July 1985 (M. Brown et al., unpublished). This species was a winter visitor to bird feeders near Nyac (H. Svensen, personal communication) and has been seen and heard in the valley floor in spruce forests the remainder of the year. At the Tuluksak River, birds were drumming on 2 June 1974; adults carried food in summer 1974 and on 21 June 1983 . We found 1.4 pairs per square kilometer in undisturbed riparian census plots in 1983. Volant young were seen on 7 July 1981 . Birds were seen almost daily in spruce woodland in fall.

Northern flicker (Colaptes auratus). VRv.

Flickers occurred only in the Kilbuck Mountains. Residents of the Tuluksak River region reported them as "sometimes present." Weir (DNW) saw a bird that may have been a northern flicker on 15 July 1976 during an aerial survey of the riparian woodlands below the foothills of the Tuluksak River.

Olive-sided flycatcher (Contopus borealis). Usr (2 June- 5 August). Specimen: RMS1962/36/26.

We found this flycatcher only at the Tuluksak River, where one to four males sang each year along $48 \mathrm{~km}$ of major streams near the edges of closed spruce forest $110-160 \mathrm{~m}$ asl. In 1983, we found 1.4 pairs per square kilometer in undisturbed riparian census plots and none in disturbed plots. Young fledged on 20 July 1962 from a nest $6 \mathrm{~m}$ above the ground in a low branch of a 15 -m-tall spruce tree. Birds were seen as late as 5 August 1981.

\section{Alder flycatcher (Empidonax alnorum). Rst?}

We saw this flycatcher at the Tuluksak River in 1962, 1978, 1981, 1983, and 1986. Birds there used riparian deciduous woodland in June 1962 and tall shrub-secondary deciduous woodlands near the river in other years. An adult pair was seen 6 July 1981. In 1983, we found 1.7 
pairs per square kilometer in disturbed riparian census plots and none in undisturbed plots. M. Brown et al. (unpublished) found alder flycatchers at the Kwethluk River on 23-27 July 1985. White and Boyce (1978) heard an Empidonax at the Kanektok River in June 1977. We saw several alder flycatchers on the lower Salmon and Aniak rivers from 25 July to 1 August 1986.

\section{Say's phoebe (Sayornis saya). VRsr, VRv.}

Phoebes nested in the Kilbuck Mountains and were seen at other locations. We saw birds at the Salmon River, and J. Bloomquist (personal communication) showed us old nests there at two locations. At the Tuluksak River, we saw one bird on 9 June and heard one on 3 other days in 1962. A nest found there on 5 July 1976 (adult on nest; DNW photo) contained five recently hatched young that were gone by 21 July; another nest found on 12July 1987 contained mostly feathered young that fledged before 21 July. Of the five Salmon and Tuluksak river nests, three were on beams about $3 \mathrm{~m}$ above the ground in open buildings, one was under the eaves of a building, and one was about $3 \mathrm{~m}$ above water on a riparian cliff. Mindell (1983) reported them from the Kisaralik River, B. J. McCaffery (personal communication) reported them there on 16,17, and 21 June 1987, and M. Brown et al. (unpublished) found them there on 9-10 August 1985 (one bird per day). One bird was seen at the Eek River on 22 June 1985 (M. Brown et al., unpublished). We saw one bird at Cape Peirce on 27 August 1970.

Horned lark (Eremophila alpestris). Usr (4 June-2 August). Specimen: RMS1962/36/27.

We found horned larks nesting at the Tuluksak River and near Goodnews Bay, and they possibly nested at the Salmon and Kisaralik rivers. Larks were also seen at the Kisaralik River (11-17 August 1985), the Kwethluk River (11-16 July 1985), and the Eck River (19-24 June 1985; M. Brown et al., unpublished). Two horned larks were seen at Slug Mountain on 4 June 1990 J. T. Klicka, personal communication). Territorial pairs in inland areas used dwarf shrub mat habitat with grasses 450-780 m asl and were absent from similar habitats at lower elevations. On the coast, they used dwarf shrub mat habitat $110 \mathrm{~m}$ asl. Densities in suitable habitat were usually $<0.6$ pair per square kilometer. Chronology was variable between years at the Tuluksak River: pairs fed young on 19 and 22 June 1974, volant young were common 28 July-2 August 1974; one was seen on 27 June 1978; and several were seen on 30 July 1981. B. J. McCaffery (personal communication) found a horned lark nest on 20 June 1987 at the Kisaralik River. At Goodnews Bay, a pair was feeding small young on 19 June 1974. D. R. Herter and D. Lloyd (personal 
communication) saw one hatching-year bird at Cape Peirce on 1 August 1981. P. D. Ameson and D. B. McDonald (personal communication) saw a horned lark on Crooked Island on 24 June 1977.

Tree swallow (Tachycineta bicolor). Cspm, Asr (13 May-25 August). Specimen: RMS1962/36/28.

Tree swallows were found throughout the study area. We saw swallows at Cape Peirce during spring migration (16-23 May) and found nests at the Salmon River, the Tuluksak River (DNW photo), Cape Peirce (MRP photo), and Platinum. B. J. McCaffery (personal communication) found swallow nests at the Kisaralik River on 16-21 June 1987. Tree swallows were at the Kwethluk River on 10-26 July 1985 and at the Eek River on 17-29 June 1985 (M. Brown et al., unpublished). Swallows were also seen at Cape Peirce on 27 June 1970 (three birds; H. P. Brokaw, unpublished), the Kanektok River in June 1977 (White and Boyce 1978), Round Island on 17 July 1974 (two birds; T. J. Eley, unpublished), and Crooked Island on 27 June 1977 (two birds; P. D. Arneson and D. B. McDonald, personal communication).

The Tuluksak River had more than 100 pairs each year along $48 \mathrm{~km}$ of major streams. Platinum mining camp had two pairs nesting each year, and Cape Peirce had one pair nesting beginning in 1973 after installation of a nest box. Birds nested in nest boxes, old woodpecker holes, and tree crevices from sea level to $300 \mathrm{~m}$ asl. Birds foraged over water but also over other habitats to $450 \mathrm{~m}$ asl.

Some tree swallows had begun nesting at the Tuluksak River by 29 May-3 June 1962 when many birds died during a series of snowstorms. In other years at the Tuluksak River, birds were in nests on 2-6 June 1974; fledged young were first seen on 21 July 1962, 24 June 1974, and 11 July 1976; and most birds were gone by 12 August 1962, 28 July 1974 and 1987, and 5 August 1976. At Cape Peirce, nesting birds remained in the area until 29 July 1976, and single birds were seen on 19 and 25 August 1976. D. R. Herter and D. Lloyd (personal communication) reported them there until 12 July 1984, and D. R. Herter and D. Lloyd (personal communication) reported them until 26 July 1981.

Violet-green swallow (Tachycineta thalassina). Usr (27 May-12 August).

Violet-green swallows nested in the Kilbuck Mountains at the Tuluksak and Salmon rivers. Numbers of pairs of swallows (DNW photo) varied at the Tuluksak River from 30 to 50 in 1962 and 1 to 4 in 1974, 1976,1978 and 1980 to $15-25$ in 1981, 1983, 1986 and 1987. Birds nested in nest boxes, holes and crevices in poplar trees, and on cliffs. They foraged over lacustrine and fluvial waters near riparian woodlands 
below $260 \mathrm{~m}$ asl. Birds were present by 27 May 1962, and many died 29 May-3 June that year during a series of snowstorms. Adults first fed young beginning 22 June 1974 and 18 July 1976 . Volant young were first seen on 28 July 1962 and about 15 July 1987 . Birds left after 12 August 1962 , before 20 July 1974 , by 5 August 1977 , in late July 1978-80, after 5 August 1981 and about 25 July 1987 . Mindell (1983) considered them common in the Nyac area. They were uncommon on the Salmon River in 1974, 1977, and 1986; they appeared to be nesting there on cliffs covered by riparian vegetation. They were seen on the Kisaralik River on 21 June 1987 (B. J. McCaffery, personal communication).

Bank swallow (Riparia riparia). Csr, VRfm (26 May-1 September). Specimen: RMS162/36/29.

This swallow was found throughout the mainland portion of the study area. Birds nested at the Tuluksak, Kisaralik, Kanektok (M. J. Fry, unpublished; J. L. Hout, personal communication), and Goodnews rivers (B. Huffmon, personal communication), Goodnews Bay, Chagvan Bay, Nanvak Bay, and the lower Togiak River. Bank Swallows were also seen at the Kisaralik River by B. J. McCaffery (personal communication) and $M$. Brown et al. (unpublished). Swallows were at the Kwethluk River on 18-26 July 1985 and at the Eek River on 17-29 June 1985 (M. Brown et al., unpublished). R. Baxter (unpublished) saw birds in summer at the Eek River. E. H. Miller (unpublished) found eight birds (two of them dead) between 9 and 17 June 1972 on Round Island. P. D. Arneson and D. B. McDonald (personal communication) saw one bird there on 29 June 1977, "suspected" nesting on Crooked Island in June-July 1977, and found it a common nesting species at Hagemeister Island.

We found about 40 pairs of bank swallows each year at the Tuluksak River, 30 pairs at Goodnews, and 2 pairs at Nanvak Bay. Birds nested in cutbanks near bays or larger streams from sea level to $360 \mathrm{~m}$ asl. Birds foraged almost entirely over water. Adults at the Tuluksak River were on fresh eggs as late as 30 July 1987 where the river had repeatedly cut the nest bank. Fledged young were first seen there on 9 August 1962. Swallows were generally present at nesting areas until 1-11 August. Migrants were seen at Cape Peirce on 5 days between 17 August and 1 September 1973.

Cliff swallow (Hirundo pyrrhonota). Ast (4 June-15 August). Specimen: RMS1962/36/30.

Cliff swallows nested throughout the study area, except in the south coastal portion. Birds nested at the Salmon River, Tuluksak River (DNW photo), near Nyac (Mindell 1983), Kisaralik River (DNW photo; Mindell 1983; B. J. McCaffery, personal communication), and Kanektok River 
(White and Boyce 1978), and Platinum. Birds have been seen in summer at the Kwethluk (17-24 July 1985; M. Brown et al., unpublished), Eek (R. Baxter, unpublished; 21-27 June 1985, M. Brown et al., unpublished) and Togiak rivers. We saw birds in spring at Cape Peirce. The number of pairs nesting at individual colonies varied. At Nyac, five buildings or machinery sites were used intermittently as colony sites. Numbers of birds there have increased from 11 to 12 pairs in 1962 to more than 100 pairs in 1981,1983 , and 1986. The Kisaralik River colonies had 10-500 nests on all suitable cliffs in canyons above timberline and fewer and smaller colonies in the lower parts of the canyons. Birds nested on buildings at Platinum village in 1974 ( 2 pairs) and 1986 (20 pairs), and the nearby mining camp (2 pairs) in 1974.

The largest colonies were found near rivers and large creeks above timberline (240-360 m asl), generally on vertical rock cliffs more than $12 \mathrm{~m}$ high. Smaller colonies were in similar locations near water, from timberline to the foothills ( $45-240 \mathrm{~m}$ asl) and sometimes under eaves of buildings or machinery. Birds nested under eaves of buildings near the coast ( $<15 \mathrm{~m}$ asl). Cliff swallows generally foraged within $200 \mathrm{~m}$ of colonies over extensive bodies of water or riparian woodlands-shrub.

Cliff swallows usually arrived at the Tuluksak River between 4 and 10 June, began building nests between 6 and 20 June, fledged young between 20 July and 10 August, and left the area by 2-15 August. Exceptions occurred in years when colonies were abandoned because of weather or disturbance. In 1978 , most pairs built nests by 18 June but abandoned their nests by 29 June. Severe snowstorms in June 1979 delayed nest building into July, and most young were still in nests on 6 August. On 20 June 1974, a colony on a gold dredge moved when the dredge was started while they were building nests. The birds started building new nests on another building on 27 June. Birds arrived at Platinum on 15 June and began building nests on 17 June 1974. Some birds that nested higher than $270 \mathrm{~m}$ asl at the Kisaralik River were still brooding young on 27 July 1979.

Barn swallow (Hirundo rustica). Rv.

We saw barn swallows some years at inland locations and on the coast. They were seen at the Tuluksak River (Nyac) in June 1974 (C. Awe, personal communication), at Kagati Lake on 24 July 1962 (M. J. Fry, unpublished), and at Goodnews Bay in summer 1973 (B. Huffmon, personal communication). Swallows were seen at Cape Peirce on 23 June 1973 (this study), 1-3 July 1973 (W. D. Arvey in Kessel and Gibson 1978), 13-14 June 1981 (D. R. Herter and D. Lloyd, personal communication), 4 July 1984 (D. R. Herter et al., personal communication), and 27-31 May and 6-13 June 1990 (K. Winker and J. Klicka, unpublished). An adult female was collected there on 2 June 1990 (K. Winker and J. 
Klicka, unpublished). To the best of our knowledge, all swallows were red-bellied ( $H$. r. erythrogaster), except for a white-bellied, presumably Old World, bird seen at Cape Peirce by MHD on 24 June 1973.

\section{Gray jay (Perisoreus canadensis). Apr.}

Gray jays were conspicuous residents of the Kilbuck and Ahklun mountains. They nested at the Salmon, Tuluksak (DNW photo), and Goodnews (B. Huffmon, personal communication) rivers. They were a common nesting bird in the Nyac area (Mindell 1983); they were found in all riparian census plots in 1983 , but no reliable estimates of numbers were possible. Jays probably nested at the Kisaralik River and were seen there 21 June 1987 (B. J. McCaffery, personal communication) and 21-27 August 1985 (M. Brown et al., unpublished). They were seen in summer at the Togiak River (this study), at the Kwethluk River on 13-27 July 1985 (M. Brown et al., unpublished), at the Eek River (R. Baxter, unpublished), and at Kagati Lake (M. J. Fry, unpublished).

Birds used riparian habitats in July-August and occasionally used tall shrub habitats to $450 \mathrm{~m}$ asl. At the Tuluksak River, recently fledged young were evident by 4 June 1962, 28 May- 5 June 1974, and 3 June 1983. Young were first independent on 22 June 1974, and some were still fed by adults to 6July 1974. Birds were still abundant on 9 November 1979 and seen there throughout most winters (C. Awe and J. Bloomquist, personal communication).

\section{Black-billed magpie (Pica pica). Rsr.}

We are uncertain as to the status of this species, possibly because of its seasonal altitudinal movements (c.g., Williamson and Peyton 1962). It was reported by local residents to occur annually at the Tuluksak River. We saw one bird on 28 July 1979 at the Kisaralik River, M. Brown et al. (unpublished) saw 6-15 birds on 19 August 1985, and Mindell (1983) and B. J. McCaffery (personal communication) also found nesting magpies there. Birds were seen at the Eek River on 7 August 1976 (R. Baxter, unpublished). Magpies were scen at the Kanektok River on 5-6 August 1973 J. L. Hout, personal communication) and nested there in June 1977 (three nests; White and Boyce 1978). We saw several single magpies and 2 flocks ( 4 and 10 birds) at Cape Peirce betwcen 21 and 27 September 1973, a juvenile at Security Cove on 23 September 1972, and birds at the Togiak River on 5 and 6 August 1973. P. D. Arneson and D. B. McDonald (personal communication) saw a magpie at Hagemeister Island on 9 July 1977 and suspected that they nested there. 


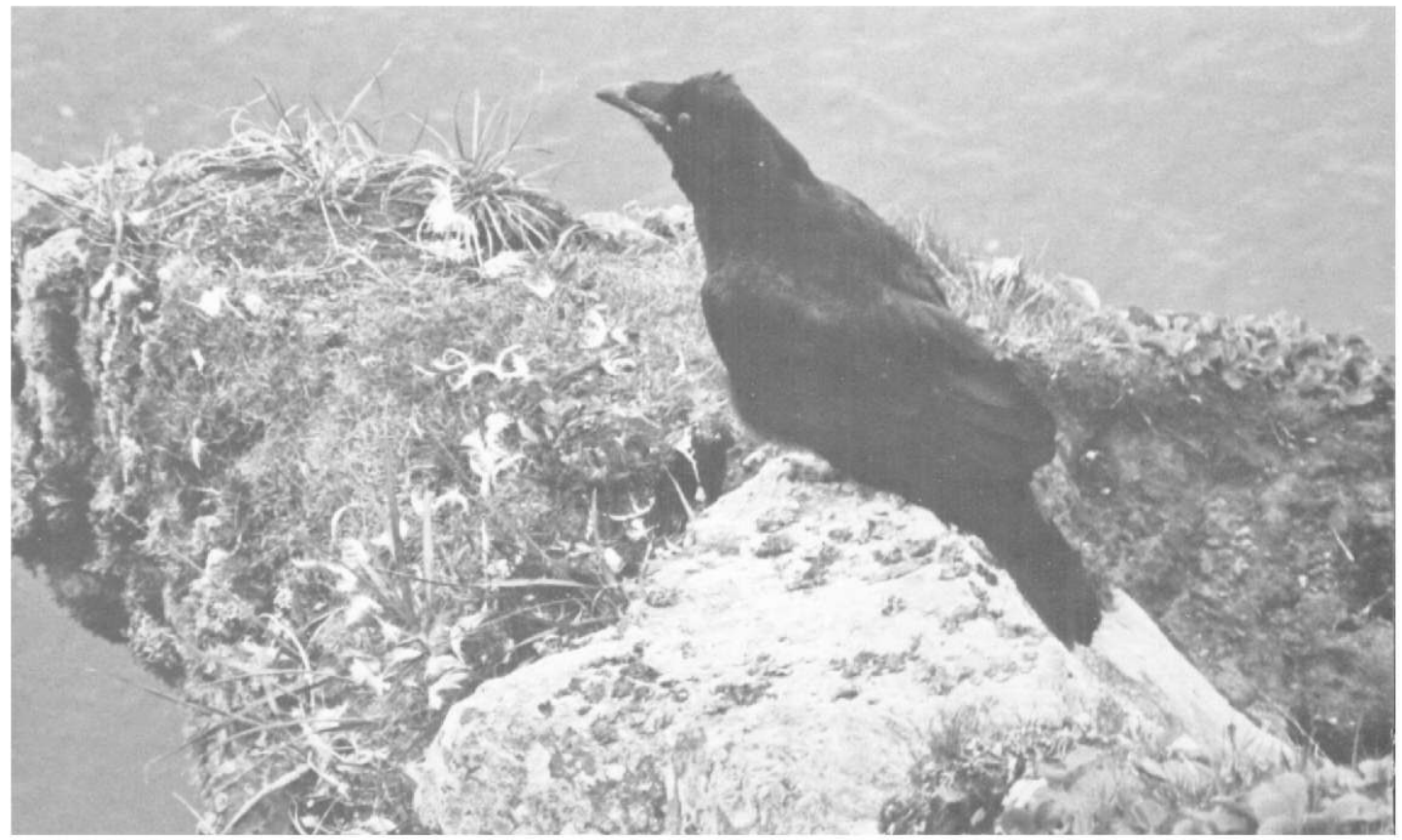

Fig. 22. Common raven at a spot used for roosting and eating prey captured along the seabird cliffs at Cape Peince. Photo by M. H. Dick.

\section{Common raven (Corvus corax). Apr.}

Ravens (Fig. 22) were ubiquitous. Birds nested at the Salmon River, the Tuluksak River, Goodnews Bay, Chagvan Bay, and Cape Peirce (MHD photo; MRP photo) and were common at all other locations. On 48 km of streams at the Tuluksak River, we found 1-2 pairs per year during 1974-79 that reared 5.8 young per year and 3 pairs per year in 3 years during $1981-87$ that reared 13.3 young per year. The increased density and fledging success corresponds with increased amounts of garbage at Nyac. In a $260-\mathrm{km}^{2}$ area near Goodnews and Chagvan bays, we found three nesting pairs and three old nests June-July 1974. At Cape Peirce, we found three to four pairs per year nesting during 3 years. One or more pairs nested at Round, Crooked, and Hagemeister islands and were "suspected" to nest on High Island in 1977 (P. D. Arneson and D. B. McDonald, personal communication).

Ravens nested on cliffs and in poplar trees and on old machinery and buildings to $370 \mathrm{~m}$ asl. Twelve successful pairs fledged $4.5 \pm 0.39$ young per nest (range, 3-6) at inland sites, and 6 broods averaged 3.8 young per pair (range, 3-6) at coastal sites. At Cape Peirce, birds were incubating 
by 4 May 1973, young hatched by 26 May 1973, and recently fledged young were found between 26 June and 27 July in all years. At the Tuluksak River, young usually fledged between 20 and 31 May, and adults fed fledged young at the nest as late as 3 July in some years. Young in three broods in the Goodnews area were within 1 week of flying on 12-17 June 1974. Ravens gathered into large flocks in fall. Thirty-four birds milled around a hill at Nanvak Bay on 29 August, and 45 birds milled around the mountain on Cape Newenham on 23 September 1973. More than 30 ravens fed on a moose (Alces alces) carcass at the Tuluksak River in November 1979.

Ravens were consistent and voracious predators of pelagic cormorant, murre, and kittiwake eggs and young when nesting near the seabird colonies. We frequently saw ravens flying to their nest areas with eggs and small chicks. Ravens were commonly observed landing next to incubating or brooding kittiwakes and murres and taking cggs or small chicks, either after the adult left or after pulling the adult from the nest. Two ravens also killed and ate two roosting kittiwakes at Chagvan Bay on 24 May 1987 (Parmelee and Parmelee 1988).

Ravens also ate carrion of moose, bear feces, dead salmon, small rodents, Empetrum and Vaccinium berries, other birds, young of various birds, and dead birds and mammals washed up on beaches. W. Arvey (personal communication) saw a raven catch and fly away with a downy sandhill crane chick at Nanvak Bay. Ravens also ate garbage and bread provided by people at Nyac (see first paragraph, this section).

Black-capped chickadee (Parus atricapillus). Cpr. Specimen: RMS1962/36/31.

Chickadees occurred inland throughout the year. They nested at the Tuluksak River (adults; DNW photo), probably nested at the Salmon and Kisaralik rivers, and were seen at the Togiak River. Mindell (1983) considered them common in the Nyac area and uncommon along the Kisaralik River; B. J. McCaffery (personal communication) found chickadees at the Kisaralik River on 21 June 1987. M. Brown et al. (unpublished) found chickadees on 20 and 22-27 August at the Kisaralik River, on 12 and 17-27 July at the Kwethluk River, and on 22-24 and 26 June 1985 at the Eek River. Birds nested in broadleaf or mixed tall shrub-trce riparian areas to $330 \mathrm{~m}$ asl, often in old woodpecker holes in dead tree stubs in beaver pond complexes. In 1983 , we found 1.7 pairs per square kilometer in disturbed riparian plots and 7.1 pairs per square kilometer in undisturbed, riparian poplar-spruce plots. At the Tuluksak River, a bird was incubating on 3 June 1974, two pairs were feeding young on 6-7 June 1983, and young fledged on 20 July 1962, 22 June 1974, and 10 July 1976 . Birds were in flocks until 20 September; after then, pairing was more evident. 
Boreal chickadee (Parus hudsonicus). Cpr. Specimen: RMS1962/36/32.

This chickadee occurred throughout the Kilbuck Mountains. It nested at the Salmon and Tuluksak (adult; DNW photo) rivers and may have nested at the Kisaralik River. Mindell (1983) considered them common in the Nyac area. M. Brown et al. (unpublished) found 1-15 chickadees per day at the Kisaralik River on 24-27 August and found 6-15 chickadees at the Kwethluk River on 26 July 1985 . We found 1.4 pairs per square kilometer in 1983 in undisturbed riparian plots, and none in disturbed plots. Birds used closed or open spruce forests for nesting but may have nested in spruce-birch and low, open spruce forests, and they were found in low numbers in other tree-shrub habitats. Chickadees (both species) composed about $1 \%$ of the breeding birds in tree-shrub habitats at the Tuluksak River. At the Tuluksak River, two birds were on nests on 9 June 1974, young fledged beginning 24 June 1974 and were common thereafter, and volant young were present by 3 July 1978. We saw family groups at the Kisaralik River in July 1979.

Red-breasted nuthatch (Sitta canadensis). VRv.

One red-breasted nuthatch was seen by M. C. Weeks in September 1974 at Platinum (Kessel and Gibson 1978).

American dipper (Cinclus mexicanus). Apr. Specimens: RMS1962/36/33 and RMS1962/36/34.

Dippers were found throughout the Kilbuck Mountains, occasionally in the Ahklun Mountains, and rarely in coastal areas. We found nests at the Salmon, Tuluksak (DNW photo), and upper Kisaralik rivers. Mindell (1983) and B. J. McCaffery (personal communication) also found nesting birds along the Kisaralik River. Dippers were also reported nesting near Goodnews and Chagvan bays (B. Huffmon, personal communication). They have been seen at the Kisaralik (19 August 1985) and Kwethluk rivers (19 July 1985; $\mathrm{M}$. Brown et al., unpublished), and in summer at the Eek River (R. Baxter, unpublished) and in the Nyac area (Mindell 1983).

At least 10 nest locations were occupied by dippers more or less annually along $\mathbf{4 8} \mathrm{km}$ of major streams at the Tuluksak River. In 4 years with full censuses, we found $5.0 \pm 0.71$ pairs per year with large or flying young. On the Salmon, Tuluksak, and Kisaralik rivers, 16 nest sites were 75-300 $\mathrm{m}$ asl and 1-7 $\mathrm{m}$ above the water surface. Nests were located at the foot of 5-60 m tall cliffs (14), on the crossbeam of a hydropower turbine exhaust (1), and on the "I" section girder of a bridge (1). At the Tuluksak River, in nests $<180 \mathrm{~m}$ asl, one bird was incubating five eggs on 1 June 1974, and four pairs were feeding young on 16-29 June 1974. In contrast, two pairs were feeding young on 27 July 1979 in nests at 
the Kisaralik River 180-270 m asl. Fledged young were common at the Tuluksak River from early July each year and were fed by adults as late as 22 August. Aerial displays and singing were intense in October-November.

Arctic warbler (Phylloscopus borealis). Csr (1 May-24 August). Specimens: RMS1962/36/40, BMNH/83sk/DNW04, $\mathrm{BMNH} / 83$ sk/DNW10, and BMNH/83sk/DNW16.

Arctic Warblers nested inland in the Kilbuck and Ahklun mountains and were occasionally seen on the coast. We found them nesting at the Tuluksak River (DNW photo) and probably nesting at the Salmon and upper Kisaralik rivers. Mindell (1983) considered them common near Nyac on 15 July 1980. Warblers were found at the Kisaralik River on 19-21 June 1987 (B. J. McCaffery, personal communication) and 918 August 1985 (M. Brown et al., unpublished), at the Kwethluk River on 10-27 July 1985 (M. Brown et al., unpublished), and at the Eek River 23-29 June 1985 (M. Brown et al., unpublished). Arctic warblers were abundant at the Kanektok River (White and Boyce 1978) and seen at Cape Peirce (eight on 1 May 1976) and the Togiak River (7-9 August 1973).

Territorial birds used open spruce woodlands with willow understory, but these warblers were also found in most valley floors and in lower hillside, open, tree-shrub habitats to $450 \mathrm{~m}$ asl. We found 5.0 pairs per square kilometer in disturbed riparian plots at the Tuluskak River in 1983 and 24.3 pairs per square kilometer in undisturbed plots. A nest we found on 7 July 1981 at the Tuluksak River was in grass-dwarf shrub habitat under tall willows in an open spruce woodland. Nesting chronologies varied widely between years. At the Tuluksak River in 1962, arctic warblers must have been overlooked (because birds were not recorded until 26 June), but fledged young with adults were evident by 18 July. In 1974 , birds were not recorded until 22 June, scolding adults were first seen on $30 \mathrm{July}$, and birds were present to 24 August or later. In 1976, aduits carried food on $14 \mathrm{July}$, and in 1978, scolding adults were common on 25 June. In 1981, one nest had six eggs and no birds were seen carrying food to young on $7 \mathrm{July}$; and many young were full grown but still being fed by adults on 27 July -5 August or later. In 1983, adults were first recorded on $6 \mathrm{June}$, and young were independent by about $10 \mathrm{June}$. In 1987 , scolding by adults was common by 21 July, volant young were being fed by adults to at least 8 August, and singing birds were heard as late as 8 August. At Kisaralik Lake ( $450 \mathrm{~m}$ asl), we found scolding adults on 26 July 1979.

Nesting arctic warblers collected at the Tuluksak River were identified by A. Knox (personal communication) as P. b. kenecottii. 
Ruby-crowned kinglet (Regulus calendula). Csr (29 May-26 August).

Kinglets were found only in the Kilbuck Mountains. We found kinglets at the Salmon and Tuluksak rivers; M. Brown et al. (unpublished) found 1-5 birds per day on 25-26 July 1985 at the Kisaralik River and 1-15 birds per day on 23 and 26 August 1985 at the Kwethluk River. At the Tuluksak River in 1983, we found 1.7 pairs per square kilometer of ruby-crowned kinglets in disturbed riparian plots and 24.3 pairs per square kilometer in undisturbed plots. Territorial birds primarily used closed spruce forests, but a few birds foraged in valley floors and slopes in all woodland and tall shrub habitats to $300 \mathrm{~m}$ asl. We found singing birds from 31 May 1974, scolding adults from 9 June 1974, molting adults carrying food on 25 July 1962, fledged young from 24 June 1974, and birds still present on 19 August 1974.

Northern wheatear (Oenanthe oenanthe). VRv.

D. R. Herter et al. (personal communication) observed a male wheatear at Cape Peirce on 18 June 1984. M. Brown et al. (unpublished) found a wheatear at the Eek River on 18 June 1985. Northern wheatears are common migrants north of our area at St. Lawrence Island and rare migrants to the southwest in the Pribilof and Aleutian islands (Kessel and Gibson 1978).

Gray-cheeked thrush (Catharus minimus). Asr (3 June-31 August). Specimen: RMS1962/36/380.

Nesting birds were found throughout the inland portion of the study area, on the coast, and on offshore islands. Birds nested at the Tuluksak River (DNW photo), Goodnews (DNW photo), and Nanvak Bay. Thrushes probably nested at the Salmon and Kisaralik rivers (this study), and were "suspected" to nest at Crooked Island in 1977 (P. D. Ameson and D. B. McDonald, personal communication). Birds were seen in the Nyac area (common on 15 July 1980; Mindell 1983), at the Kisaralik River (common in 1982, Mindell 1983; seen 16-21 June 1987, B. J. McCaffery, personal communication; seen on 9 days during 10-27 August 1985, M. Brown et al., unpublished), at the Kwethluk River (10 days during 10-26 July 1985, M. Brown et al., unpublished), at the Kanektok River (abundant in June 1977; White and Boyce 1978), at the Eek River (in summer, $R$. Baxter, personal communication; on 11 days during 17-29 June 1985, M. Brown et al., unpublished), at the Togiak River (one in August 1973; this study), and on Round Island (one on 23 July 1974, Francis H. Fay in T. J. Eley, unpublished; one heard on 27 Junc 1976, R. MacIntosh, unpublished). 
Gray-cheeked thrushes used almost all low shrub to closed forest habitats to $600 \mathrm{~m}$ asl. At the Tuluksak River in 1983, we found 37 pairs per square kilometer in disturbed and undisturbed riparian habitats. Four nests were $0.3-2 \mathrm{~m}$ above the ground or water and in willow or birch in riparian shrub. At the Tuluksak River, one bird was laying eggs on $11 \mathrm{June}$ and another incubating three eggs on 22 June 1962; one nest had four small young on 24 June 1974; and another had three newly hatched young on 1 July 1978 . Adults carried food from mid-June 1962 and 25 June 1974, and young fledged from 26 June 1978 and 20 June 1983. One bird at Goodnews was laying eggs on 16 June 1974.

Swainson's thrush (Catharus ustulatus). Csr (28 May-25 August). Specimen: RMS1962/36/39.

This thrush was found in most locations, nested at the Salmon and Tuluksak (DNW photo) rivers, may have nested at the Kisaralik River, and probably nested at Goodnews and Chagvan bays. They were common in the Nyac area on 15 July 1980 (Mindell 1983). Information on habitat and chronology is primarily from the Tuluksak River. Pairs were abundant there in 1962, common in 1974, 1978, 1979, and 1981, and uncommon to rare in 1977,1983 and 1986 . We found 2.9 pairs per square kilometer in undisturbed riparian plots and none in disturbed plots. They used most mature broadleaf or mixed woodlands to $330 \mathrm{~m}$ asl and were less often in riparian tall shrub and secondary riparian woodland. Two nests were 0.5-2 $\mathrm{m}$ above the ground in main forks of tall shrubs. In 1962, a nest had four small young in it on 25 June, and fledged young were widespread in early July; in 1974, one nest had three eggs on 22 June, and young flew from another on 1 July. Singing postbreeding birds were heard from 30 July, and birds were present into the last week of August.

Hermit thrush (Catharus guttatus). Usr (3 June-31 July). Specimen: RMS1974/119/08.

Hermit thrushes were found in interior portions of the study area and on the coast. We found nesting birds at the Salmon and Tuluksak rivers and near Goodnews (DNW photo) and probably nesting birds at Cape Peirce. Hermit thrushes were uncommon in the Nyac area on 15 July 1980 (Mindell 1983). Birds were seen at the Kisaralik River on 21 June 1987 (B. J. McCaffery, personal communication) and 9 and 14 August 1985 (M. Brown et al., unpublished), at the Kwethluk River on $11,20,23$, and 26 July 1985 (M. Brown et al., unpublished), at the Eek River on 7 August 1976 (R. Baxter, unpublished) and 5 days during 17-29 June 1985 (M. Brown et al., unpublished), at Round Island on 27 June 1976 (five birds; R. MacIntosh, unpublished), and were "suspected" to 
nest at Round, Summit, Crooked, High, and Hagemeister islands in 1977 (P. D. Arneson and D. B. McDonald, personal communication).

Singing or scolding birds were found mainly in two different biotypes: at the edges of birch and some spruce woods with either dwarf shrub mat terraces or open riparian spruce-cottonwood (90-180 m asl); and at the interface between upper edges of subalpine alder-willow shrub and dwarf shrub mat $(90-250 \mathrm{~m}$ asl along the coast; $370-750 \mathrm{~m}$ asl inland) on steep, rocky slopes with discontinuous cover. Only 1 pair (0.1 pair per square kilometer) was found in disturbed riparian woodland at the Tuluksak River in 1983. In undisturbed birch woods on south-facing slopes elsewhere, singing males seemed to be spaced roughly 100-200 m apart.

A nest near Goodnews was on a southwest-facing rock outcrop ( $240 \mathrm{~m}$ asl) near the summit of a steep coastal hill. It was about $30 \mathrm{~m}$ above the main edge of low alder shrub in dwarf mat shrub with scattered alders, grasses, and dwarf willow. The nest site was in a tussock at the base of a large rock crevice. The nest contained four eggs with embryos about two-thirds developed 19 June 1974. Singing hermit thrushes were common at Cape Peirce at vegetated sea slopes from 11 June to 16 July 1970; none were seen or heard there in 1973 and 1976. We saw a pair copulating at Pyrite Point on 11 June 1973.

American robin (Turdus migratorius). Csr (2 April-25 August). Specimen: RMS1962/36/35.

Robins nested in the northern Kilbuck Mountains and were less common to the south. We found nesting birds in inland areas at the Salmon River, Tuluksak River (DNW photo), the Kisaralik River, Platinum, and the Togiak River. Mindell (1983) also found nesting birds along the Kisaralik River and considered it a common bird in the Nyac area; robins were seen daily on 16-21 June 1987 (B. J. McCaffery, personal communication) and during 6 days on 12-27 August 1985 at the Kisaralik River (M. Brown et al., unpublished). M. Brown et al. (unpublished) found robins on 11 days during 11-27 July 1985 at the Kwethluk River. Robins were seen at the Eek River in summer (R. Baxter, unpublished; 17-24 and 26-29 June 1985, M. Brown et al., unpublished) and the Kanektok River on 4 August 1973 J. L. Hout, personal communication), and were thought to nest at Kagati Lake (M. J. Fry, unpublished). Along the coast, we saw a robin at Cape Peirce (13 May 1973) and Cape Newenham (21 May 1973).

Birds nested above $15 \mathrm{~m}$ asl along the coast and inland $90-340 \mathrm{~m}$ asl. We found 5.3 pairs per square kilometer in disturbed and undisturbed riparian habitats at the Tuluksak River in 1983. Nest sites near Nyac were in the main valley floors or lower slopes in the vicinity of man-made structures (four), riparian woodland (one), secondary broadleaf wood- 
land (one), and the upper edge of a spruce forest (one). Nests were 1-4 m above the ground on beams of buildings and bridges (four), in willow (one), and in spruce (two). Nesting birds foraged along the edges of all habitats on the main valley floor then, after the young fledged, mainly at edges of spruce-secondary broadleaf woods. More birds foraged up into the alpine (to $925 \mathrm{~m}$ asl) as berries got ripe.

Six nests at the Tuluksak River averaged 3.8 eggs per clutch (range, 3-4), and four broods averaged 3.5 young (range, 3-4). Robins arrived there as early as $\mathbf{2}$ April, but generally in mid-May (C. Clark, Jr., personal communication). Eggs hatched between 1 and 4 June (four nests), young fledged beginning $18 \mathrm{June}$ (five nests), and birds were present to at least 13-25 August. In 1983, robins nested exceptionally early at the Tuluksak River and may have raised two broods; one brood fledged on 3 June, and eggs were laid in the same nest later in the season. Birds at Platinum in 1974 incubated eggs by 12 June (two nests), with a late clutch laid beginning 4 July.

Varied thrush (Ixoreus naevius). Asr (5 May-22 September). Specimens: RMS1962/36/37, RMS1962/36/36, BMNI/83sk/DNW08, and BMNH/83sk/DNW17.

Varied thrushes nested in the northern Kilbuck Mountains, were rare to the south, and were seen only once on the coast. Birds nested at the Salmon and Tuluksak (DNW photo) rivers and possibly nested at the Kisaralik River. Birds were considered common in the Nyac area and the Kisaralik River in 1980 and 1982, respectively (Mindell 1983); seen daily on the Kisaralik River on 16-21 June 1987 (B. J. McCaffery, personal communication) and 25-27 August 1985 (M. Brown et al., unpublished); seen 6 days during 17-26 July 1985 at the Kwethluk River (M. Brown et al., unpublished); uncommon along the Kancktok River in June 1977 (White and Boyce 1978); and seen 17, 22, and 26-29 Junc 1985 at the Eck River (M. Brown et al., unpublished). We saw them once at Cape Peirce on 5 May 1973.

At the Tuluksak River, birds nested $180-310 \mathrm{~m}$ asl in tall mixed riparian woodlands (five nests in open canopy, one nest in closed canopy) and upper edges of spruce forest (one nest). Nests were in spruce trees (six nests) and willows (one nest) about $2.5 \mathrm{~m}$ above the ground. Birds foraged in mixed tall riparian woodlands, secondary broadleaf woodlands, edges of spruce-birch and birch, and shrub habitats, as well as in subalpine shrub habitat during berry season. In 1983, we found 1.7 pairs per square kilometer in disturbed riparian plots and 18.6 pairs per square kilometer in one undisturbed riparian plot.

Six clutches at the Tuluksak River averaged 3.8 eggs (range, 3-5). The earliest spring arrival was on 15 May 1962 . Varied thrushes were incubating by 1 June 1974 and as late as 24 June 1974 . In early spring 
1983 , we found scolding adults on 12 June. Newly hatched to half-grown nestlings were found on 26 June 1962 and 10 June 1974, and fledged young were found at the end of July 1962 , 30 July 1974, 15 July 1976, and 25 June 1978. Birds were generally present until 22 August-September. One bird was found there on 22 September 1977.

Yellow wagtail (Motacilla flava). Uspm, Asr, Ufm (30 May-28 August).

Yellow wagtails migrated throughout the study area and nested everywhere except the northem Kilbuck Mountains. Nesting pairs were found at the Kisaralik River, Goodnews Bay, Chagvan Bay, Nanvak Bay, and Cape Peirce. Wagtails were common and suspected to nest on Crooked Island in 1977 (P. D. Arneson and D. B. McDonald, personal communication). Birds were seen at the Kisaralik River on 16-21 June 1987 (B. J. McCaffery, personal communication) and 8-18 August 1985 (M. Brown et al., unpublished); were seen at the Kwethluk River on 12-13 and 17-27 July 1985 (M. Brown et al., unpublished); were seen at the Eek River during 7 days on 17-28 June 1985 (M. Brown et al., unpublished) and in summer (R. Baxter, unpublished); were abundant along the Kanektok River in June 1977 (White and Boyce 1978); seen on Round Island on 15 June 1972 (two birds; E. H. Miller, unpublished); and were common at Platinum and Chagvan Bay in summer $1969 \mathrm{~J}$. L. Hout, personal communication). Spring migrants were at the Tuluksak River ( 6 and 8 June 1983). Fall migrants were observed inland at Kagati Lake (M. J. Fry, unpublished; J. L. Hout, personal communication) and the Kanektok River (M. J. Fry, unpublished), as well as coastal areas at the Togiak River, Goodnews Bay, Chagvan Bay, Nanvak Bay, Cape Peirce (this study), and Round Island (T. J. Eley, unpublished).

Territorial yellow wagtails used coastal lowlands and upland areas with moist dwarf shrub meadows or grass meadows (primarily Elymus arenarius on the coast) or open valley floor formations from sea level to $450 \mathrm{~m}$ asl. Birds foraged at the edges of all types of bodies of water. The highest density was just under 18 scolding pairs per square kilometer in old tailings along the Salmon River (Platinum) on 20 June 1974. Scolding birds tended to be several hundred meters apart in adjacent tundra habitat. Earliest arrivals at Cape Peirce were on 30 May 1970 and 1976. Bull (in Friedmann 1933) collected an adult male at Goodnews Bay on 15 June 1933. Adults carried food by 18 June 1974 near Platinum, and independent young were found there by $19 \mathrm{July} 1974$. Newly fledged young were seen at Cape Peirce on 16 July 1981 (D. R. Herter and D. Lloyd, personal communication). Fall migrants were at the Kisaralik River between 26-31 July 1979, at Goodnews and Chagvan bays in July 1974, at the Togiak River during 5-9 August 1973, and at Cape Peirce and Nanvak Bay until 16-28 August. Migrants 
were at Kagati Lake as late as 15 August 1962 (M. J. Fry, unpublished) and found at Round Island from 15 July 1974 (T. J. Eley, unpublished).

White wagtail (Motacilla alba). VRv.

A single bird was seen catching insects on the beach $1.6 \mathrm{~km}$ west of Pyrite Point by MHD on 11 June 1973 . White wagtails occasionally occur along the coast north of our area (Kessel and Gibson 1978).

Water pipit (Anthus spinoletta). Asr, Cfm (4 May-27 September). Specimens: RMS1962/36/42, and UAM2644.

Water pipits nested throughout the mainland portion of the study area and on some offshore islands. They nested each year at the Salmon and Tuluksak (DNW photo) rivers, near Goodnews and Chagvan bays, at Cape Peirce, and at Crooked Island (P. D. Arneson and D. B. McDonald, personal communication), probably nested at the Kisaralik River (B. J. McCaffery, personal communication), and possibly nested at Cape Newenham. Pipits were seen at the Kisaralik River on 16-21 June, and seen carrying food there on 17 June 1987 (B. J. McCaffery, personal communication). Pipits were also seen at the Kisaralik River during 17 days from 9 to 28 August and at the Kwethluk River during 7 days from 11 to 27 July 1985 (M. Brown et al., unpublished). Pipits were seen at the Kanektok River in 1 of 3 years (one bird also seen June 1977; White and Boyce 1978) and at the Eek River in summer (R. Baxter, unpublished) and during 6 days from 18 to 29 June 1985 (M. Brown et al., unpublished). Birds were at Round Island on 27 June 1976 (R. Macintosh, unpublished) and at Round and Summit islands in 1977 (P. D. Arneson and D. B. McDonald, personal communication). Bull (in Friedmann 1933) collected one adult female at Goodnews Bay on 11 June 1933.

At the Tuluksak River, three to six pairs per kilometer were seen in dwarf shrub mat in the alpine zone (average, $1,250 \mathrm{~m}$ asl). Densities along the top of Cape Peirce were two to eight birds per kilometer (two to six pairs in an 86-ha plot) in dry dwarf shrub mat with exposed gravel. Two nests at Cape Peirce were in hollows under edges of stone in a grass-heath area of dwarf shrub mat habitat on moderate slopes, and D. R. Herter et al. (personal communication) found one nest in tall grass.

Nesting chronology was similar for most years. Pipits were first seen at the Tuluksak River on 2 June 1962 and 21 June 1983; birds were on eggs (one clutch of seven) by 8 June 1974; adults fed young by 23 June 1974; newly fledged young were common but still fed by adults on 27 June 1974; and young were independent by 1 August 1974. Along the coast, water pipits arrived at Cape Peirce and Nanvak Bay on 4 May 1973; males were displaying from 10 May 1973; adults were carrying food on 23 June 1970; young fledged from 15 July 1970 and between 15 July and 
3 August 1973; and independent young were common after 3 August in all years. A nest had 5 eggs there on 9 June 1984 (D. R. Herter et al., personal communication). At Goodnews and Chagvan bays, a male was displaying on 22 May 1987 (D. F. Parmelee and J. M. Parmelee, unpublished). In 1974, one bird was incubating six eggs on 12 June, adults were carrying food by 20 June, and young were independent by 19 July, although some young were still fed by adults on 24 July. At Round Island, a nest had five eggs on 14 June 1972 (E. H. Miller, unpublished) and 25 birds were seen there on 27 June 1976 (R. MacIntosh, unpublished). Fall migrants were first seen along rivers in lower elevations at the Tuluksak River on 5-25 August (1962-81) and at the Kisaralik River on 27 July 1979. Birds were along the coast as late as 27 September 1973. Coastal migrants were in the vicinity of Slug Mountain on $28 \mathrm{July}$, and at Cape Peirce by mid-August in all years.

Bohemian waxwing (Bombycilla garrulus). Rsr?, Rfm.

We found waxwings at the Salmon, Aniak, Tuluksak, and Togiak rivers; one bird was seen at the Kisaralik River on 21 June 1987 (B. J. McCaffery, personal communication). Several territorial pairs were seen at the Salmon and Aniak rivers in 1974 and 1986 but not in 1977 or 1979. We saw single pairs or birds at the Tuluksak River on 9 July 1979, 27 July 1981, from 14 June 1983, and from 3 August 1986; and small flocks were there on 14-15 October 1977 and 5 November 1979. Two birds were at the upper Togiak River on 5 August 1973.

Northern shrike (Lanius excubitor). Usr ( 6 June-14 October).

Shrikes nested throughout the Kilbuck Mountains. We found scolding adults at the Salmon River, nests and recently fledged young (DNW photo) at the Tuluksak River, and fledged young at the Kisaralik River. Three to eight broods fledged young in 8 years of incomplete counts along $48 \mathrm{~km}$ of streams at the Tuluksak River. Birds were seen at the Kisaralik River in 1982 (Mindell 1983), in 1985 (13, 15, 18, and 26 August; M. Brown et al., unpublished), and in 1987 (16-21 June; B. J. McCaffery, personal communication); and at the Eek River in summer (R. Baxter, unpublished). One bird was seen at Kagati Lake on 20 August 1962 (M. J. Fry, unpublished). Territorial birds used open low forest or broken tall shrub areas, usually on lower terraces and hillsides $75-360 \mathrm{~m}$ asl. Young moved to lower elevations in the valley floors after the nesting season.

At the Tuluksak River, one shrike nest contained four young near fledging on 17 July 1962. In 1974, scolding adults were first found on 27 June, young fledged on 13 July, independent young were present by 28 July and still present to 28 August. We found full-grown, dependent young on 10 and 16 July 1976 and 21 July 1987 . In other years, we found 
young to 22-25 August and adults to 14 October. Fledged young were at the Kisaralik River on 27 and 30 July 1979.

Orange-crowned warbler (Vermivora celata). FCsr (31 May-31 August). Specimens: UAM2643, RMS1962/36/43, RMS1962/36/44, and BMNH/83sk/DNW03.

Orange-crowned warblers nested throughout the study area. Birds nested each year at the Tuluksak River (DNW photo) and some years at Cape Peirce, and probably nested each year at the Salmon and Kisaralik rivers and at Chagvan and Goodnews bays; warblers were seen at the Kisaralik River (16-21 June 1987, B. J. McCaffery, personal communication; 6 days during 10-20 August 1985, M. Brown et al., unpublished), at the Kwethluk River (11 days during 10-27 July 1985, M. Brown et al., unpublished); and at the Eek River ( 9 days during 17-29 June 1985; M. Brown et al., unpublished). Warblers were common and "suspected" to nest on Crooked Island in 1977 (P. D. Arneson and D. B. McDonald, personal communication).

Pairs and nests were $15-150 \mathrm{~m}$ asl in shrub thickets on the coast or riparian woodlands with willows in valley floors in inland areas. One nest at the Tuluksak River was in an open riparian white spruce forest in a cavity at the base of a willow. We found 17 pairs per square kilometer in disturbed and undisturbed riparian plots at the Tuluksak River in 1983. Birds were present on our arrival at the Tuluksak River on 31 May-2 June during all years. One bird incubated five eggs there on 22 June 1974, and young fledged between 7 and 14 July in all years. Some birds were still feeding nestlings between 16 and $20 \mathrm{July}$ in all years, and birds were present on 22-23 August 1974 and 1977. Along the coast near Cape Peirce, birds used dense willows at the Slug River on 10 June 1973 and 28 June 1970, and at Slug Mountain on 10 June 1973. Fledglings chased adults on 28 July 1970 , and one bird was present at Security Cove on 31 August 1973. No birds were seen near Cape Peirce in 1976. D. R. Herter et al. (personal communication) found them at Cape Peirce on 28 June and 15 July 1984 .

Yellow warbler (Dendroica petechia). Rsr?, Rfm. Specimens: RMS1974/1 19/06, and BMNH/83sk/DNW12.

This species occurred irregularly throughout the study area. We found no nests, but recorded singing males in summer at most locations. Birds were seen at the Salmon River only on 8 August 1977. At the Tuluksak River (dead adult; DNW photo), we found territorial birds in 1979 (4-14 July), 1980, and 1981. We saw one bird there on 18 August 1977 and none there in 1962,1974, 1976, and 1987. Mindell (1983) considered them uncommon in the Nyac area on 15 July 1980 . At the 
Tuluksak River in 1983, we found at least two singing males in riparian broadleaf tree habitat and found three males in $0.1 \mathrm{~km}^{2}$ of riparian tall shrub thicket above timberline. Singing males were present at Kisaralik Lake ( $450 \mathrm{~m}$ asl) in July 1979 . Yellow warblers were seen in summer at the Kisaralik River in 1982 (Mindell 1983), in 1985 (6 days during 10-20 August; M. Brown et al., unpublished), and in 1987 (17 June; B. J. McCaffery, personal communication). Warblers were also found at the Kwethluk River ( 5 days during 11-26 July 1985; M. Brown et al., unpublished), the Eek River (R. Baxter, unpublished), Kagati Lake (27 July 1962; M. J. Fry, unpublished), the Kanektok River (common in June 1977; White and Boyce 1978), Round Island in 1972 (4 days during 12-18 June; E. H. Miller, unpublished) and 1976 (27 June; R. Macintosh, unpublished), and Crooked and Hagemeister islands ("suspected" nesting in June-July 1977; P. D. Arneson and D. B. McDonald, personal communication). We found singing males at Platinum on 20 June 1974, south of Slug Mountain on 11 June 1973, and at the Slug River on 28 June 1970. We saw birds at the Togiak River on 5 and 8 August 1973. D. R. Herter et al. (personal communication) saw birds at Cape Peirce on 16 and 28 June and 9 and 15 July 1984 .

Yellow-rumped warbler (Dendroica coronata). FCsr (19 May-24 August). Specimen: RMS1962/36/47.

This warbler nested in the Kilbuck Mountains and was seen elsewhere. Birds nested each year at the Salmon and Tuluksak rivers and possibly nested at the lower Kisaralik River; warblers were seen at the Kisaralik River on 21 June 1987 (B. J. McCaffery, personal communication) and 28 August 1985 (M. Brown et al., unpublished). One male $D$. $c$. coronata was seen on 19 May 1976 at Cape Peirce. One bird was also seen at Cape Peirce on 12 June 1984 (D. R. Herter et al., personal communication). At other sites, birds were seen at the Kwethluk River (4 days during 17-26 July 1985; M. Brown et al., unpublished), at the Eek River (summer; R. Baxter, unpublished), and at the Kanektok River (two singing males in June 1977; White and Boyce 1978). We found 3.3 pairs per square kilometer in disturbed and 22.9 pairs per square kilometer undisturbed riparian plots (mainly spruce-poplar) at the Tuluksak River in 1983.

Territorial birds used tall shrub thickets in riparian habitat $75-300 \mathrm{~m}$ asl. At the Tuluksak River, we first found warblers on 3 June 1983, saw adults carrying food beginning 24 June 1974, and found young fledging on 1 July 1974 . Family groups were common to 28 July 1974 ; single birds were in feeding flocks with other passerines from 7 August 1974. Birds in basic plumage were seen on 4 August 1962, 24 August 1974, and 19 August 1977. 
Blackpoll warbler (Dendroica striata). FCsr (3 June-31 August). Specimens: RMS1962/36/48, BMNH/83sk/DNW05, BMNH/83sk/DNW09, and BMNH/83sk/DNW11.

Blackpoll warblers were found in the Kilbuck and Ahklun mountains and twice on the coast. Warblers nested at the Tuluksak River and probably nested at the Salmon and Kisaralik rivers. Mindell (1983) found them an uncommon nesting bird on 15 July 1980 near Nyac. Warblers were seen at the Kisaralik River (16-21 June 1987; B. J. McCaffery, personal communication), at the Kwethluk River (10 days during 10-27 July 1985; M. Brown et al., unpublished, and at the Eek River ( 7 days during 21-29 June 1985; M. Brown et al., unpublished). Two birds were seen at the Kanektok River in June 1977 (White and Boyce 1978). We saw a blackpoll warbler once along the coast at Security Cove (one male on 31 August 1973). An adult female was collected on 2 June 1990 at Cape Peirce (K. Winker and J. Klicka, unpublished).

Territorial birds in the Kilbuck Mountains used open valley floors in tall shrub thickets and spruce forests with dense shrub understory. $\Lambda t$ the Tuluksak River in 1983, we found $\mathbf{4 5 . 0}$ pairs per square kilometer in disturbed and 28.6 pairs per square kilometer in undisturbed riparian plots. Adults there carricd food from 24 June 1974, fledged young were seen 12 through mid-July 1962, and birds were present until 23 August 1977. Adult males were molting by 18 July 1979 , and some females were in basic plumage by 25 July 1962 .

Northern waterthrush (Seiurus noveboracensis). Asr (11 Junc25 August). Specimen: RMS1962/36/45.

Waterthrushes nested throughout the Kilbuck Mountains, possibly nested in the Ahklun Mountains, and were seen on the coast. Birds nested each year at the Tuluksak River, probably nested at the Salmon and Kisaralik rivers, and were seen along the coast south of Slug Mountain (one on 11 Junc 1973), and at Togiak Lake and the Togiak River ( 3 and 10 August 1973). Birds have been seen in the Nyac area on 15 July 1980 (common; Mindell 1983); along the Kisaralik River in 1982 (common; Mindell 1983), 1985 (9-10 and 20 August; M. Brown et al., unpublished), and 1987 (20-21 June; B. J. McCaffery, personal communication); at the Kwethluk River (12 days during 10-27 July 1985; M. Brown et al., unpublished); at the Eck River (in summer [R. Baxter, unpublished] 6 days during 19-21 June 1985 [M. Brown ct al., unpublished]); and along the Kanektok River (one heard; White and Boyce 1978). Bull (in Friedmann 1933) collected one adult female on 11 June 1933 near Goodnews Bay.

Territorial waterthrushes used all riparian woodlands and shrub habitats (except black spruce) 60-300 $\mathrm{m}$ asl and occasionally used damp 
places away from riparian areas. We found 80.0 pairs per square kilometer in disturbed and 40.0 pairs per square kilometer in undisturbed riparian plots mainly in densc, tall shrub thickets within timberline at the Tuluksak River in 1983. Adults there carried food to young beginning on 26 June 1962 and 24 June 1974, and fledged young were seen between 1 and 13 July 1974, 11 July 1979, and 7 July 1978. We first heard postbreeding songs from 8 August 1962, 29 July 1974, and 6 August 1979 to as late as 21 August 1977. Birds were last seen on 25 August 1974.

Wilson's warbler (Wilsonia pusilla). Asr (31 May-7 September). Specimen: RMS1962/36/51.

This warbler nested throughout the inland portion of the study area and probably nested in coastal areas. We found breeding birds each year at the Salmon and Tuluksak rivers, territorial birds at the Kisaralik River, Goodnews and Chagvan bays, and Cape Peirce, and birds at the Togiak River (August 1973). Wilson's warblers were common in the Nyac area on 15 July 1980 (Mindell 1983), common along the Kisaralik River in 1982 (Mindell 1983), found there in 1985 (1-15 birds per day during 6 days on 12-20 August; M. Brown et al., unpublished), and were present there in 1987 (16-21 June; B. J. McCaffery, personal communication). Warblers were also found at the Kwethluk River (1-15 birds per day over 8 days on 11-27 July 1985; M. Brown et al., unpublished) at the Eek River (up to $>15$ birds per day during 11 days on 17-29 June 1985; M. Brown et al., unpublished), at Kagati Lake (M. J. Fry, unpublished), and at the Kancktok River (abundant in June 1977; White and Boyce 1978). E. H. Miller (unpublished), R. MacIntosh (unpublished) and P. D. Arneson and D. B. McDonald (personal communication) found warblers at Round Island in June 1972, 1976, and 1977, respectively. P. D. Arneson and D. B. McDonald (personal communication) suspected that they nested at Round, Crooked, and High islands in 1977.

Territorial Wilson's warblers used all woodland-shrub thicket habitats $6-450 \mathrm{~m}$ asl. Birds were most common in riparian tall shrub thickets and less common in other shrub formations. Territorial birds also occasionally used dense closed spruce with little understory. We found 66.7 pairs per square kilometer in disturbed and 44.3 pairs per square kilometer in undisturbed riparian plots in 1983 at the Tuluksak River. Families with newly fledged young were generally found between 26 June-14 July 1974 and as late as 28 July 1974 at the Tuluksak River. We found birds to 25 August 1974 and 23 August 1977 inland and as late as 7 September 1976 on the coast. 
American tree sparrow (Spizella arborea). Uspm, Csr, Rfm (2 May-25 September). Specimens: RMS1962/36/55 and BMNH/83sk/DNW02.

Sparrows nested throughout the mainland portion of the study area. We found nests at the Salmon and Tuluksak rivers. Birds probably nested at the Kisaralik River, Kagati Lake (M. J. Fry, unpublished), the Kanektok River (White and Boyce 1978), and Goodnews and Chagvan bays. Tree sparrows were seen near Nyac on 15 July 1980 (Mindell 1983), along the Kisaralik River in 1980 (Mindell 1983), 1985 (8-28 August; Brown et al., unpublished), and 1987 (16-21 June; B. J. McCaffery, personal communication), along the Kwethluk River (10-27 July 1985; M. Brown ct al., unpublished), and along the Eck River (summer; R. Baxter, unpublished; 17-29 June 1985; M. Brown et al., unpublished).

American tree sparrows nested at 9-550 $\mathrm{m}$ asl in low to tall shrub habitats, especially at the edges. We found 61.7 pairs per square kilometer in disturbed and 24.1 pairs per square kilometer in undisturbed riparian plots at the Tuluksak River in 1983. where we also found 10.0 pairs per squarc kilometer in riparian shrub thickets above timberline. At the Tuluksak River, one female began laying eggs on 1 June 1974. We found fully feathered young there between 25 and 30 June 1962 and 1974 and recently fledged young as late as 28 July 1974 . In most years, birds were in the area until late August, with the latest recorded on 25 September 1977. At the Kisaralik River, M. Brown et al. (unpublished) found 1 to "many" ( $>15)$ birds per day on 16 days from 8 to 28 August 1985. Along the coast, we also saw them in fall at the Togiak River (August 1973), the Slug River (5 September 1973), and Security Cove (23 Scptember 1973), as well as the Cape Peirce area in spring (7-12 May 1973; 2-8 May 1976), summer (20 June 1970), and fall (23 August 1970; 7-23 September 1973).

Savannah sparrow (Passerculus sandwichensis). Asr, Cfm (3 May-25 September). Specimens: UAM2642 and UAM3134.

Savannah sparrows were possibly the most common land bird in the study area; they nested and migrated throughout the area. In inland areas birds nested at the Salmon, Tuluksak, Kisaralik, and (possibly) Togiak rivers. Mindell (1983) found sparrows uncommon in the Nyac arca on 15 July 1980 and a common nesting bird along the Kisaralik River in 1982; sparrows were seen along the Kisaralik River in 1985 (10-18, 22 August; M. Brown et al., unpublished) and in 1987 (16-19 Junc; B. J. McCaffery, personal communication). Sparrows probably nested at Kagati Lake (M. J. Fry, unpublished) and at the Kancktok River (J. L. Hout, personal communication) where White and Boyce (1978) found them abundant. Sparrows were found at the Kwethluk River ( 1 to $>15$ birds per day on 
12 days during 11-25 July; $M$. Brown et al., unpublished) and at the Eek River ( 1 to $>15$ birds per day on 11 days during 17-29 June 1985; M. Brown et al., unpublished). Along the coast, we found breeding birds at Goodnews Bay, Chagvan Bay, Cape Peirce, and Nanvak Bay; Bull (in Friedmann 1933) collected an adult female at Goodnews Bay on 15 June 1933. Savannah sparrows nested at Round Island (T. J. Eley, unpublished; E. H. Miller, unpublished; and P. D. Arneson and D. B. McDonald, personal communication) and Crooked Island (P. D. Arneson and D. B. McDonald, personal communication), and were suspected to nest at Summit and Hagemeister islands in 1977 (P. D. Arneson and D. B. McDonald, personal communication).

Territorial savannah sparrows were found to $500 \mathrm{~m}$ asl in all open habitats or boundaries between clearings and shrub, except wet dwarf shrub mats, bare areas, and dry dwarf shrub mats. We found 5.0 pairs per square kilometer in disturbed and 11.4 pairs per square kilometer in undisturbed riparian plots at the Tuluksak River in 1983. In the open habitats we sampled there, we found 2.3-3.0 pairs per linear kilometer. At the Tuluksak River young fledged as early as 23 June 1974 , but usually fledged between 3 and 10 July in most years; movements of birds through the area were evident on 14-15 August 1977, and no birds were recorded after mid-August.

Along the coast at Cape Peirce and Nanvak Bay, savannah sparrows arrived on 4 May 1973 and 3 May 1976. A copulating pair was seen there on 7 June 1970 . Nests were found there with eggs between 20 June and 13 July 1970,1973 , and 1976 (this study), on 15 June 1981 (one nest with four eggs; D. H. Herter and D. Lloyd, personal communication), and on 21-30 June 1984 ( $N=8$ nests; $x=4.75$ eggs per nest; $S E=0.16$; range, 4-5; [D. R. Herter et al., personal communication]). Young were in nests between 20 June and 13 July 1970, 1973, and 1976 (this study); between 20 June and 15 July 1981 (D. Lloyd and D. H. Herter, personal communication), and on 2 July 1984 (one nest with five young; D. R. Herter et al., personal communication). Young fledged between 28 June and 16 July 1970,1973 , and 1976. Birds left the breeding areas by 3 September 1976, and flocks were in the area from early August to 25 September. At Round Island, a nest had four eggs on 11 June and another had five eggs on 15 June 1972 (E. H. Miller, unpublished); full grown young were present by 14 July 1974 (T. J. Eley, unpublished). At Chagvan Bay, pairs were first evident beginning 26 May 1987 (D. F. Parmelee and J. M. Parmelee, unpublished); at Goodnews and Chagvan bays, we found no young between 11 and 20 June, but found full-grown young by 16 July 1974 . 
Fox sparrow (Passerella iliaca). Csr (12 May-20 September). Specimens: RMS1962/36/59, BMNH/83sk/DNW15, and RMS1974/119/04.

This sparrow nested throughout the area. Fox sparrows nested at the Salmon and Tuluksak rivers and Goodnews and Chagvan bays; they probably nested at the Kisaralik River, possibly nested at Round Island in June 1972 (E. H. Miller, unpublished), and were "suspected" to nest at Summit, Crooked, and High islands in 1977 (P. D. Arneson and D. B. McDonald, personal communication). Sparrows were uncommon along the Kisaralik River in 1982 (Mindell 1983); present in 1985 (1-15 birds per day on 8 days during 11-28 August; $M$. Brown et al., unpublished); and present in 1987 (16-19 June; B. J. McCaffery, personal communication). Birds were also present at the Kwethluk River (1-5 birds per day on 9 days during 12-27 July 1987; M. Brown et al., unpublished); present at the Eek River (summer 1976 [R. Baxter, unpublished]; 1 to $>15$ birds per day on 9 days during 17-29 June 1985; [M. Brown et al., unpublished]); common at the Kanektok River in June 1977 (White and Boyce 1978); found at Chagvan Bay on 24 May 1987 (D. F. Parmelee and J. M. Parmelee, unpublished); and found at Togiak Lake and Cape Peirce in summer.

Fox sparrows were generally found in dense tall shrub habitats (primarily alder and willow) 9-350 $\mathrm{m}$ asl. Numbers of birds varied between years at the Tuluksak River. Six pairs were found in 1962, they were abundant in 1974 and 1987, and common in other years. We found 33.3 pairs per square kilometer in disturbed and 7.1 pairs per square kilometer in undisturbed riparian plots at the Tuluksak River in 1983. In undisturbed habitats numbers varied from 0 in riparian low-tall shrub thickets above timberline to 8.6 pairs per square kilometer in dense riparian tall shrub thickets and woodland. We found about 10 pairs at Goodnews in June-July. At Cape Peirce and Nanvak Bay, we found fox sparrows 2 of 3 years: none in 1970, fairly common in 1973, and one on 25 August 1976. D. R. Herter and D. Lloyd (personal communication) saw one there on both 15 July 1981 and 13 July 1984 .

Nesting chronology was similar each year at the Tuluksak River. Two fox sparrow nests had four and five eggs each on 2 and 3 June 1974, respectively; scolding adults were found on 23 June and newly fledged young were present after 26 June. Young were first independent by 12 July, but some young were still fed by adults as late as 28 July. Birds remained at the Tuluksak River until 25 August, with the latest observation on 20 September 1977. Three nests were found at Goodnews in 1974: one had four eggs on 18 June, one had an adult carrying food to small young on 20 June, and one had newly fledged young on 20 June. Specimens from the Tuluksak River and Platinum were evidently $P$. $i$. $z a b o r i a$, but a much grayer female was seen paired to a male $P$. i. zaboria near the mouth of the Salmon River (Platinum) on 20 June 1974. 
Song sparrow (Melospiza melodia). VRv.

Song sparrows were seen on Round Island by T. J. Eley (unpublished) where he recorded two on 17 July and one on 21 July 1974 . One bird was "larger and darker than the other two birds and was reminiscent of song sparrows on the Aleutian Islands." M. J. Fry (unpublished) reported a few song sparrows at Kagati Lake on 20 July 1962.

\section{Lincoln's sparrow (Melospiza lincolnii). Rsr?}

Lincoln's sparrows were identified only at the Tuluksak River during 3 of 10 years: in July 1962, June and July 1983, and July-August 1986, one to three singing males per year were seen at the edges of riparian tall shrubs and freshwater marshes. We found one pair (1.14 pairs per linear kilometer) in undisturbed riparian woodlands in 1983.

\section{Golden-crowned sparrow (Zonotrichia atricapilla). Asr, Cfm} (13 May-22 September). Specimens: RMS1962/36/58 and UAM2645.

Golden-crowned sparrows nested throughout the study area, although they were more abundant on the coast than inland. Sparrows nested at the Salmon, Tuluksak, and Kisaralik rivers (Mindell 1983), Cape Peirce, Nanvak Bay, Round Island (T. J. Eley, unpublished; E. H. Miller, unpublished), and Crooked Island (P. D. Arneson and D. B. McDonald, personal communication). They probably nested at Goodnews and Chagvan bays (this study), and Kagati Lake (M. J. Fry, unpublished) and were "suspected" to nest at Summit, High, and Hagemeister islands (P. D. Arneson and D. B. McDonald, personal communication). Sparrows were present at the Kisaralik River in 1985 (1-15 birds per day on 8 days during 9-22 August; M. Brown et al., unpublished) and in 1987 (seen daily in 16-21 June; B. J. McCaffery, personal communication); found at the Kwethluk River ( 1 to $>15$ birds per day on 12 days during 10-27 July 1985; M. Brown et al., unpublished); found at the Eek River (1 to $>15$ birds per day on 17-29 June 1985; M. Brown et al., unpublished); abundant at the Kanektok River (White and Boyce 1978); common near Nyac on 15 July 1980 (Mindell 1983); and seen at Chagvan Bay on 22-25 May 1987 (D. F. Parmelee and J. M. Parmelee, unpublished).

Territorial golden-crowned sparrows used edges of dry, low-to-tall shrub habitats and edges of open woodlands with shrub understory (15-720 m asl). At the Tuluksak River in 1983, we found only 0.5 pairs per linear kilometer in undisturbed riparian woodland, of which $<0.1$ pairs per linear kilometer were within timberline and 5.5 pairs per linear kilometer above timberline. At the Tuluksak River, birds built nests by 8 June 1974 , adults carried food to young by 22 July 1962 , young fledged mid-to-late July during all years, and birds were gone by early August. Along the coast, scolding adults were common at Goodnews after 16 June 
1974. Adults were present each year at Cape Peirce beginning on 13-19 May, nests had eggs in them between $18 \mathrm{June}$ and $4 \mathrm{July}$, and fledglings were first seen between 6 and 28 July. Other records for Cape Peirce include a nest with four eggs on 4 July 1964 (J. G. King, unpublished), two nests with four eggs each on 21-23 June, and one nest with four young on 30 June 1984 (D. R. Herter et al., personal communication). At Round Island, E. H. Miller (unpublished) found two nests with five eggs each on 17-18 June and three nests with one egg and two, three, or four chicks each on 25-28 June 1972; T. J. Eley (unpublished) found fledged young beginning in mid-July 1974 .

Fall migrants began to appear in August throughout the study area: Birds were seen in early August at Kagati Lake (M. J. Fry, unpublished), were present August-22 September at Cape Peirce and Nanvak Bay (this study), and were seen August 1973 at the Togiak River. Miners at Nyac use the traditional name of golden-crowned sparrows from their song; they are called the "No-gold-here" bird.

White-crowned sparrow (Zonotrichia leucophrys). Ast (14 May25 September). Specimens: RMS1962/36/56 and RMS1962/36/57.

Sparrows nested in the northern Kilbuck Mountains and were uncommon or rare elsewhere. Inland, they nested at the Salmon and Tuluksak rivers (this study), were common nesting birds at the Kisaralik River (Mindell 1983), and seen there in summer (16-19 June 1987; B. J. McCaffery, personal communication) and fall (10-27 August 1985; M. Brown et al., unpublished). Sparrows were present at the Kwethluk River (1-15 birds per day on 10 days during 11-27 July 1985; M. Brown et al., unpublished); present at the Eek River (1-15 birds per day on 21-26 June 1985; M. Brown et al., unpublished); uncommon at the Kanektok River (White and Boyce 1978); and present at the Togiak River. Along the coast, they probably nested at Goodnews and Chagvan bays; one bird was seen at Round Island on 20 July 1974 (T. J. Eley, unpublished), and they were rare and suspected to nest at Crooked Island in 1977 (P. D. Ameson and D. B. McDonald, personal communication).

Sparrows nested $15-425 \mathrm{~m}$ asl at edges of riparian habitats in tall shrubs, other tall shrub woodlands, low shrubs, and low, open spruce forests. We found 11.7 pairs per square kilometer in disturbed and 24.3 pairs per square kilometer in undisturbed riparian habitats at the Tuluksak River in 1983. One bird there was incubating eggs on 8 June 1974. Young fledged on 26 June 1962, 25-30 June 1974, and 4 July 1979, and independent young were seen after $10 \mathrm{July}$ each year. We found birds at the Tuluksak River into August and as late as 25 September 1977. Along the coast, we saw birds at Cape Peirce between 14 May and 11 June (three birds in 1970, five birds in 1973, eight birds in 1976); four birds were seen at Cape Peirce between 3-6 August 1981 (D. R. Herter and D. Lloyd, 
personal communication) and 9 days between 13 June and 16 July 1984 (one to four birds; D. R. Herter et al., personal communication); and single birds were noted in or near willows at Chagvan Bay on 22-27 May 1987 (D. F. Parmelee and J. M. Parmelee, unpublished). We saw one young white-crowned sparrow at the Togiak River on 8 August 1973.

\section{Harris' sparrow (Zonotrichia querula). Vrv.}

This sparrow was found only once. A single adult male was collected on 1 July 1990 at Cape Peirce (K. Winker and J. Klicka, unpublished). This specimen is the first record for western Alaska. Previous records in Alaska include one bird collected at Colville River on 25 June 1958 (Gabrielson and Lincoln 1959), two birds at Barrow on 11 June 1973 (Kessel and Gibson 1978), and numerous records in south-coastal Alaska.

Dark-eyed junco (Junco hyemalis). Usr, Rfm, VRwr (29 May-4 September). Specimen: RMS1974/119/11.

Juncos nested in the northern Kilbuck Mountains and migrated along the coast in fall. Birds nested each year in moderate-to-low numbers at the Salmon and Tuluksak rivers and possibly nested at the Kisaralik River. Juncos were uncommon in the Nyac area on 15 July 1980 (Mindell 1983), seen on 21 June 1987 at the Kisaralik River (B. J. McCaffery, personal communication), and seen on 23 and 27 July 1985 at the Kwethluk River (M. Brown et al., unpublished). Six birds were seen at Cape Peirce between 29 August and 4 September 1976.

Territorial birds were $75-300 \mathrm{~m}$ asl in open spruce forests with dense understory and in riparian mixed-spruce forest edges. We found 3.3 pairs per square kilometer in disturbed and 8.6 pairs per square kilometer in undisturbed riparian habitats at the Tuluksak River in 1983. Young fledged there beginning the first week in July 1962, mid-July 1974 , and from 26 June 1978 ; family groups were common to 28 July 1974 and 21 July 1978 . Juncos were at Nyac in some winters (C. Awe, personal communication; J. Bloomquist, personal communication; C. Clark, Jr., personal communication), but our latest date there was 23 August 1977. Juncos were at the Kisaralik River in fall 1985 (1-15 birds per day on 25-26 August; M. Brown et al., unpublished).

Lapland longspur (Calcarius lapponicus). Aspm, Asr, Afm (28 April-27 September).

We found longspurs throughout the mainland and at offshore islands. In inland areas, they nested at the Salmon, Tuluksak, and Kisaralik rivers and Kagati Lake (M. J. Fry, unpublished). They were common along the Kisaralik River in 1982 (Mindell 1983); seen there in 1985 
( 1 to $>15$ birds per day on 13 days during 9-25 August; M. Brown et al., unpublished); and seen there in 1987 (16, 17, and 20 June; B. J. McCaffery, personal communication). Longspurs were at the Kwethluk River ( 1 to $>15$ birds per day on 12 days during 11-26 July 1985; M. Brown et al., unpublished); seen at the Eek River (in summer; $R$. Baxter, unpublished; 1 to $>15$ birds per day on 17-29 June 1985, M. Brown et al., unpublished); abundant along the Kanektok River (White and Boyce 1978); and seen at the Togiak River (1 on 8 August 1973). Longspurs nested along the coast at Goodnews and Chagvan bays (this study) and Cape Peirce (this study; D. R. Herter et al., personal communication). Birds were "suspected" to nest at Round, Crooked, and Hagemeister islands in 1977 (P. D. Ameson and D. B. McDonald, personal communication) and were scen at Round Island (R. Macintosh, unpublished; E. H. Miller, unpublished).

Nesting longspurs used dwarf shrub mat and dwarf shrub meadow habitats. Numbers varied between locations and years. We found one to three pairs per linear kilometer in the arctic-alpine zone at the Tuluksak River; however, higher numbers were found in valley floors above timberline, and lower numbers were found on moist tundra terraces within the timberline. At Goodnews and Chagvan bays, we usually found about $\mathbf{5 0}$ adults per day in June and July. Densities of longspurs at Cape Peirce in May and June varied between $11.1 \pm 1.3$ pairs per survey (range, 9-14) in 1973 and $5.9 \pm 0.5$ pairs per survey (range, 4-8) in 1976, or approximately 3.3 pairs per kilometer in 1973 and 1.7 pairs per kilometer in 1976.

Nesting chronology varied between locations and years. No flying young were seen at the Tuluksak River between 25 and 30 June 1962, but fledged young were found in flocks on 7 July 1974. At Kagati Lake, M. J. Fry (unpublished) found some nests with eggs or young after 20 July 1962. At Goodnews, one bird was incubating five eggs on 12 June 1974, an adult was carrying food on 16 June 1974, and a nest had four small nestlings on 19 June 1974. In years with intensive surveys at Cape Peirce, males began displaying on 3 May 1976 and 5 May 1973, a copulating pair was seen on 1 June 1973, and eggs ( $N=8$ total nests; $x=4.2 \pm 0.4$ eggs per nest; range, $3-7)$ were found between 6 June and 6 July each year. Small young were found beginning on 14 June 1970 , and newly fledged young were seen beginning on 19 June 1973 and 7 July 1976; adults were on territories until 17 July 1976. D. R. Herter and D. Lloyd (personal communication) found a nest at Cape Peirce with five eggs on 14 June 1981, and, in 1984, D. R. Herter et al. (personal communication) found nests with eggs from 21 to 28 June ( $N=4$ nests; $x=4.5$ eggs per nest; range, $4-5$ ) and newly hatched young on 24 June (two eggs and three young) and 28 June (two eggs and two young). One 
pair was seen copulating on 25 May 1987 at Chagvan Bay (D. F. Parmelee and J. M. Parmelee, unpublished).

Spring migration of longspurs began at Cape Peirce before 28 April 1976 and on 3 May 1973 and continued into mid-May both years. Fall migrants were usually first noted in late July at the Tuluksak River and mid-August along the coast. At both Goodnews and Cape Peirce, migrants were still in the area until late September and may have been there later.

Snow bunting (Plectrophenax nivalis). Cspm, Asr, Cfm (18 April10 October). Specimen: RMS1962/36/62.

Buntings were found throughout the study area, especially in alpine and coastal cliff areas. Birds nested each year at the Salmon and Tuluksak rivers, Goodnews Bay, Chagvan Bay, and Cape Peirce (DNW; MHD photo). They probably nested at Cape Newenham and possibly nested at the Kisaralik River. Mindell (1983) considered them uncommon along the Kisaralik River in 1982, and birds were seen there on 14 August 1985 (M. Brown et al., unpublished). M. Brown et al. (unpublished) also saw buntings at the Kwethluk River on 15 July 1985 and the Eek River on 17-19 June 1985. T. J. Eley (unpublished) saw one bird at Round Island in July 1974.

Pairs were found on the coast along cliffs and screes (18-300 $\mathrm{m}$ asl). Inland, they were $800-1200 \mathrm{~m}$ asl (and occasionally as low as $550 \mathrm{~m}$ asl) in dwarf shrub mat on screes, cliffs, and fell-fields. We found low numbers of breeding birds ( $<1.0$ pairs per linear kilometer) at the Tuluksak River on summit ridges and plateaus. At old tailings along the Salmon River near Platinum, we found 38 scolding pairs per square

Fig. 23. Snow bunting nest on windswept ridge; Cape Peirce, 24 June 1970. Photo by M. H. Dick.

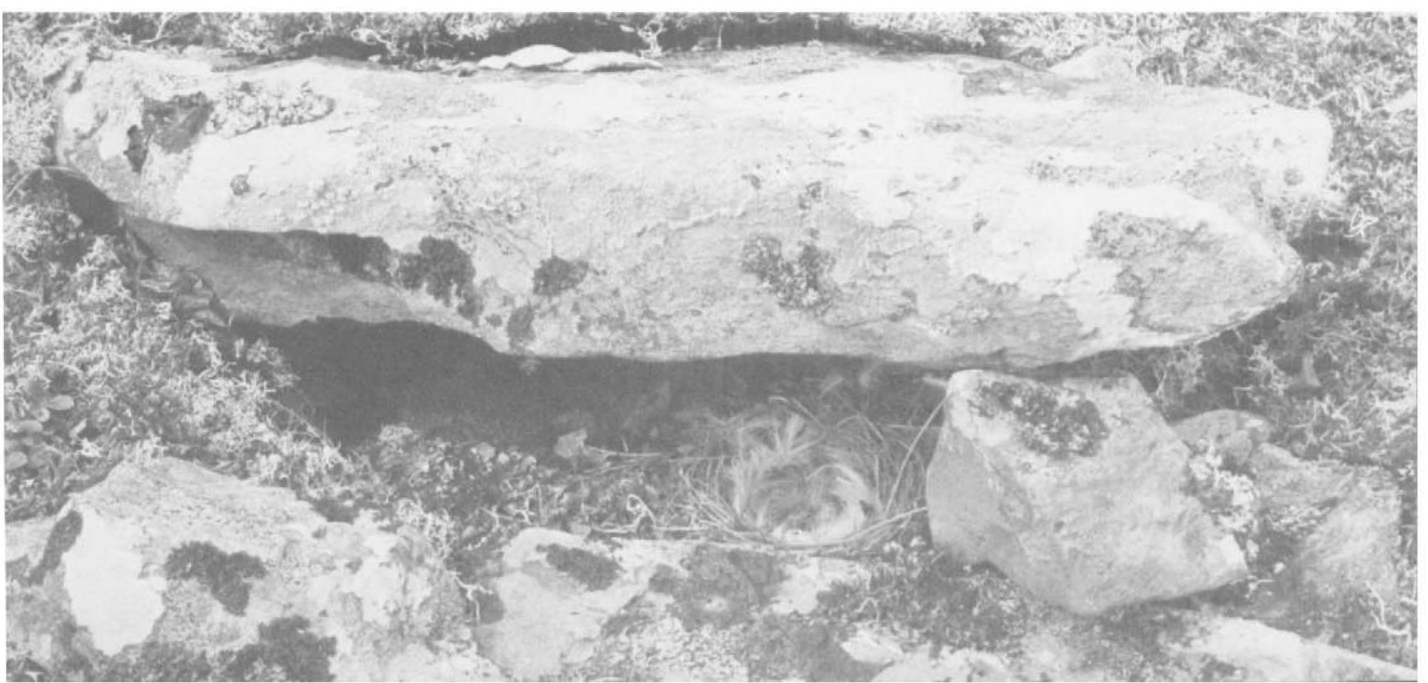


kilometer on 20 June 1974. Along the cliff tops at Cape Peirce in 1976, we found $5.6 \pm 1.1$ pairs per square kilometer.

Nesting chronology varied between locations and years, with nests along the coast appearing earlier than those inland. At the Tuluksak River, some adults carried food on 7 July 1974 , young were independent in late July in all years, and birds were found as late as 10 October 1977. At Chagvan Bay, flight displays were first noted on 23 May 1987 (D. F. Parmelee and J. M. Parmelee, unpublished). Near Platinum, we found newly fledged young and young in nests on 18-20 June 1974. At Cape Peirce, pairs were on territories by 1 May 1973 and 2 May 1976. One nest there (Fig. 23) had four eggs on 24 June, the eggs hatched by 1 July, and the young fledged by 16 July 1970 . Newly fledged young were first recorded on 27 June 1970 (three young; H. P. Brokaw, unpublished), on 3 July 1984 (four young; D. R. Herter et al., personal communication), and 25 July 1976. Independent young were generally found at Cape Peirce in late July.

Buntings migrated along the coast at Chagvan Bay in spring as early as 18 April 1973 (D. I. Eisenhauer, personal communication). We found flocks at Cape Peirce until 2 May, but thereafter we found only pairs and singles. Spring migrants used the dune habitat extensively where they fed on seeds of Honckenya peploides. Flocks of birds were first noted on the coast in fall in early August and were common into October. Birds on the coast foraged in intertidal as well as terrestrial habitats in summer and fall.

McKay's bunting (Plectrophenax hyperboreus). VRv.

One bird was seen among 15 snow buntings (D. I. Eisenhauer, personal communication) on 18 April 1973 at Chagvan Bay. McKay's buntings are occasionally found along the Bering Sea coast of mainland Alaska in spring (Kessel and Gibson 1978).

Red-winged blackbird (Agelaius phoeniceus). VRv. Specimen: UAM2631.

MHD found one juvenile male in the marsh near Nanvak Bay on 2 September 1973. Red-winged blackbirds are considered a casual summer and fall visitant to western Alaska (Kessel and Gibson 1978). Other records in the region are from Cape Lisburn, Cape Thompson, Kotzebue, and Wales (Kessel and Gibson 1978). 
Rusty blackbind (Euphagus carolinus). Usr, Rfm (1 June-22 September).

Blackbirds nested in the Kilbuck Mountains where they formed colonies at the Salmon, Tuluksak, and Kisaralik rivers. We also found birds at Togiak Lake, the Togiak River, and, in some years, at Nanvak Bay. Birds were seen in the Nyac area on 15 July 1980 (uncommon; Mindell 1983), and at the Kisaralik River on 28 August 1985 (M. Brown et al., unpublished) and 21 June 1987 (B. J. McCaffery, personal communication). Blackbirds were also found at the Kwethluk River ( 1 to $>15$ birds per day on 6 days during 13-26 July 1985; M. Brown et al., unpublished); in summer at the Eek River (R. Baxter, unpublished; 17, 21, and 23 June 1985, M. Brown et al., unpublished); on 4 August 1972 at Kagati Lake (one; M. J. Fry, unpublished); and in early June 1974 near Goodnews (B. Huffmon, personal communication).

Blackbirds nested in beaver pond complexes in closed or open spruce forests $75-300 \mathrm{~m}$ asl, then later (July-August) moved their young to main rivers. We found $10-20$ pairs $(0.2-0.4$ pairs per linear kilometer) each year along $\mathbf{4 8} \mathrm{km}$ of major streams at the Tuluksak River between 1962 and 1983; however, birds were much more common in 1952 when they fed daily at the large garbage dump. The garbage dump was much smaller during 1962-83. At the Tuluksak River, adults carried food items from 1 June 1974 and 4 June 1983, and fledged young were common from 24 June 1974. Families moved to rivers beginning on 10 July 1974 , and migration was in progress by 24 August 1974. A single bird was present as late as 22 September 1977 . We found a few migrants at Nanvak Bay between 3 and 12 September 1973 and on 29 August 1976.

Rosy finch (Leucosticte arctoa). FCsr (27 April-2 September). Specimens: UAM3110 and RMS1974/119/12.

We found rosy finches throughout the study area where we visited appropriate habitat. They probably nested inland at the Salmon and Tuluksak rivers, were seen on 15 July 1985 at the Kwethluk River (M. Brown et al., unpublished) and on 19 June 1985 at the Eek River (M. Brown et al., unpublished), possibly nested along the coast near Goodnews and Chagvan bays and at Cape Newenham, and nested at Cape Peirce. They probably nested at Round Island in 1974 (T. J. Eley, unpublished) and 1977 (P. D. Arneson and D. B. McDonald, personal communication), and were uncommon and "suspected" to nest on Crooked Island (P. D. Arneson and D. B. McDonald, personal communication). We found territorial birds inland in dry dwarf shrub mats and screes and fell-field habitats (600-1250 m asl), and in similar habitats on the coast at lower elevations. T. J. Eley (unpublished) found them on 
grassy flats on Round Island. Densities were low in all areas, and less than one pair per square kilometer was found in suitable l.abitat at the Tuluksak River.

Birds foraged for insects on sea cliffs and among algae in the rocky intertidal areas, and they were frequently seen eating seeds in terrestrial habitats. Adults fed persistent, begging young at Cape Peirce beginning on 15 July 1970 .

Pine grosbeak (Pinicola enucleator). Upr. Specimen: RMS1962/36/52.

We found grosbeaks only in the Kilbuck Mountains. They occurred at the Salmon River (C. Awe, personal communication), we saw them at the Aniak River, and one was seen at the Kwethluk River (17 July 1975; M. Brown et al., unpublished). Grosbeaks nested at the Tuluksak River each summer except 1979, when none were seen. We found 2. 9 pairs per square kilometer in undisturbed and none in disturbed riparian habitats in 1983. Territorial birds were in tall open spruce forest on terraces and lower hillsides, and birds foraged during summer primarily in tall shrub or young deciduous woods in the valley floors (75-300 $\mathrm{m}$ asl). In fall and early winter, birds foraged mainly in riparian tall willow and young poplar (75-225 $\mathrm{m}$ asl), especially on balsam poplar buds.

At the Tuluksak River, adult males were singing on 7 June 1974, a male carried food on 22 July 1962, and adults were commonly giving "anxiety" calls after 9 July 1971 and 1987,7 July 1976, 18 July 1978, and 20 June 1983. The start of anxiety calling was associated with food-gathering flights to valley floor formations and presumably with feeding young. This suggests breeding and feeding habitats more distinct than those suggested by Newton (1972) and Erskine (1977).

White-winged crossbill (Loxia leucoptera). Rpr?, Uv, Uwr (1 1 July-5 November). Specimen: RMS1974/119/140.

We found crossbills only in the Kilbuck Mountains at the Salmon and Tuluksak rivers where they probably nested, but they were found only from late summer and during most falls and winters. One to $>15$ birds per day were seen at the Kwethluk River on 21-23 and 26-27 July 1985 (M. Brown et al., unpublished). Birds generally used riparian habitats and open and closed spruce forests $75-350 \mathrm{~m}$ asl.

Males sang during July-August in 1974, 1977, 1978, 1981, 1986, and 1987; however, no crossbills were found in summer 1952, 1962, 1976, 1979 , and 1983. An adult female collected on 14 July 1974 had regressing follicles and a refeathering incubation patch. Birds were present each fall beginning in late August and observed into November. Observations 
by residents at Nyac suggest that some birds may winter there (J. Bloomquist, and C. Clark, Jr., personal communication).

Common redpoll (Carduelis flammea). Asr, Ufm (7 May-7 November). Specimens: WFB869, RMS1962/36/53, BMNH/83sk/DNW1, BMNH/83sk/DNW07, RMS1974/119/15, RMS1974/119/22, RMS1974/119/23, RMS1974/119/01, and RMS1974/119/16.

Common redpolls nested inland and along coastal portions of the study area and were along the coast in spring and fall. A few common redpolls were at Cape Peirce in spring 1973 (two on 7 May, and seven on 14 May). Birds nested at the Salmon and Tuluksak rivers and Goodnews and Chagvan bays, possibly nested at the Kisaralik River, and were "suspected" to nest at Summit, Crooked, High, and Hagemeister islands (P. D. Arneson and D. B. McDonald, personal communication). Redpolls were common near Nyac on 15 July 1980 (Mindell 1983), common along the Kisaralik River in 1982 (Mindell 1983), 1985 (1-15 birds per day on 7 days during 10-27 August; Brown et al., unpublished), and 1987 (16-19 June; B. J. McCaffery, personal communication), and seen at the Kwethluk River ( 1 to $>15$ birds per day on 10-27 July 1985; M. Brown et al., unpublished), the Eek River (R. Baxter, unpublished; 1 to $>15$ birds per day on 11 days during 17-29 June 1985 [M. Brown et al., unpublished]), Kagati Lake (M. J. Fry, unpublished), the Kanektok River (White and Boyce 1978), the Togiak River, and Round Island. At Round Island, a dead bird was found on 12 June 1972 (E. H. Miller, unpublished) and a single bird on 27 June 1976 (R. MacIntosh, unpublished). We observed an extremely red C. flammea at Cape Peirce on 23 June 1970. Redpolls were common on Crooked Island in June-July 1977 (P. D. Arneson and D. B. McDonald, personal communication).

Pairs of common redpolls used low to tall shrub habitats and shrubby edges of forests. Some birds moved to low shrub thicket and dwarf shrub mat habitats to $1,350 \mathrm{~m}$ asl by late July. At the Tuluksak River, we found 10 pairs per square kilometer and about twice as many unpaired birds in both disturbed and undisturbed riparian habitats in 1983. Redpolls are not accurately estimated by the breeding bird census technique we used (Erskine 1977). In fall, birds fed in valley floors, both in shrub habitats and shrubby edges of forests. At the Tuluksak River, some birds were building nests on 8 June 1962, one bird was incubating on 6 June 1983, scolding adults were common after 8 June 1974, and young were common after 25 June 1962 and 28 June 1978 . Flocks were found on 5-15 July in all years. 
Hoary redpoll (Carduelis hornemanni). Csr, Ufm (20 Junc6 November). Specimens: RMS1974/119/05, RMS1974/119/07, and RMS1974/119/17.

Hoary redpolls nested in at least two coastal areas and wcre found inland and on the coast in fall. This species or intermediates (hoary $\times$ common redpolls) nested at Chagvan Bay (D. F. Parmelee and J. M. Parmelce, unpublished), and probably nested within $10 \mathrm{~km}$ of Goodnews Bay at the Salmon River (Platinum), Red Mountain, the Platinum camp, and Kemuk Mountain. Migrating or wintering hoary redpolls were seen between 12 September and 6 November at Goodnews Bay and at the Tuluksak River. In fall at both locations, hoary redpolls were more common than common redpolls.

Hoary redpolls and intermediates (DNW photos) were in nesting territorics (9-350 $\mathrm{m}$ asl) either in low-to-tall riparian shrub sheltered by cutbanks or at the upper edge of subalpine low shrub habitats. At Chagvan Bay, two freshly built nests were found on 24 May and another on 26 May, and one egg was in one nest on 26 May 1987 (D. F. Parmelee and J. M.

Fig. 24. Territorial male redpolls collected within $100 \mathrm{~m}$ of cach other at the mouth of the Salmon River (Platinum); June 1974. Subsequent electrophoretic analysis of feather proteins indicated they were Carduelis flammea (top) and C. flammea $\times$ hornemanni. Photo by D. N. Weir. 
Parmelee, unpublished). In fall, birds were along the coast and in valley floors inland in lowto-tall shrub formations and at the edges of forests.

Specimens collected in the Goodnews Bay area (Fig. 24) included three apparently pure $C$. hormemanni, but electrophoretic analysis of feather proteins indicated that all were intermediate (A. Knox, personal communication). 


\section{Discussion}

Here we provide documentation for the expansion of breeding distribution (known or possible) of several species described by the Amcrican Ornithologists' Union (1983), reported by Kesscl and Gibson (1978), or not previously reported: fork-tailed storm-petrel, doublecrested cormorant, red-faced cormorant, brant, king eider, white-tailed ptarmigan, Pacific golden-plover, black-bellied plover, lesser yellowlegs, Say's pheobe, and Bohemian waxwing. Some species such as doublecrested cormorant, red-faced cormorant, brant, and black-bellied plovers nested annually, whereas the others (fork-tailed storm-petrel, king eider, white-tailed ptarmigan, etc.) nested or were thought to nest (Bohemian waxwing) only in some ycars.

We also document unusual occurrences for frigatebird, Baikal teal, American kestrel, bristle-thighed curlew, Terck sandpiper, rufous hummingbird, and red-winged blackbird. The bristle-thighed curlew probably migrates through the area each fall, whereas the other species are truly unusual occurrences. There is little evidence to suggest that species that are apparently new to the area, but that occur annually, represent recent expansion of their ranges. As at many remote locations in Alaska, an increase in field studies results in documentation of species generally found in low numbers or restricted habitats. Specics found either nesting or present outside their normal ranges are generally thought to be a result of storms (birds bcing "blown in'), fluctuations in conditions at the usual nesting area (prairic droughts), or sporadic increases in population numbers (low winter mortality). It is probable that the distributions of these species will be further clarified as more and more people visit the area and as the number and intensity of ficld studies in the area increases.

The 140 breeding or probably brecding birds of the Ahklun and Kilbuck mountains and offshore islands are predominantly of North American ( $58 \% ; N=81$ ) zoogeographic affinity (lable 7). Scveral nesting forms are of Beringian (24\%; $N=33$ ) and Panboreal affinity (17\%; $N=24)$, with the remainder of Old World affinity (1\%; $N=2)$. Among 44 species of fairly-common-to-abundant migrants and visitants in our area, the North American group is best represented ( $11 \%$ of 44 species), while Panboreal and Beringian elements are approximatcly equally represented (Table 8 ). These proportions of breeding birds and migrants are similar to those of regularly occurring brecding birds and visitants on the Seward Peninsula (Kessel 1989) and reflect the similar forces operating in the entire region over geologic time. 
Table 7. Zoogeographic affinity of species breeding (B) or probably breeding $(b)$ on the study area.

\begin{tabular}{|c|c|c|c|c|}
\hline Common name & Beringian & Panboreal & North American & old World \\
\hline Red-throated loon & & B & & \\
\hline Pacific loon & & & B & \\
\hline Common loon & & & b & \\
\hline Fork-tailed storm-petrel & B & & & \\
\hline Double-crested cormorant & & & B & \\
\hline Pelagic cormorant & B & & & \\
\hline Red-faced cormorant & B & & & \\
\hline Tundra swan & & & B & \\
\hline Greater white-fronted goose & & & b & \\
\hline Emperor goose & B & & & \\
\hline Brant & B & & & \\
\hline Canada goose & & & B & \\
\hline Green-winged teal & & & B & \\
\hline Mallard & & B & & \\
\hline Northern pintail & & B & & \\
\hline American wigeon & & & B & \\
\hline Greater scaup & B & & & \\
\hline Common eider & B & & & \\
\hline King eider & & B & & \\
\hline Harlequin duck & B & & & \\
\hline Oldsquaw & & B & & \\
\hline Black scoter & B & & & \\
\hline Surf scoter & & b & & \\
\hline White-winged scoter & & & b & \\
\hline Common goldeneye & & & B & \\
\hline Bufflehead & & & B & \\
\hline Common merganser & & & & B \\
\hline Red-breasted merganser & & B & & \\
\hline Osprey & & & B & \\
\hline Bald eagle & & & B & \\
\hline Northern harrier & & & B & \\
\hline Northern goshawk & & & B & \\
\hline Red-tailed hawk & & & B & \\
\hline Rough-legged hawk & & & B & \\
\hline Golden eagle & & & B & \\
\hline American kestrel & & & B & \\
\hline Merlin & & & B & \\
\hline Peregrine falcon & & & b & \\
\hline Gyrfalcon & & B & & \\
\hline Spruce grouse & & & B & \\
\hline Willow ptarmigan & B & & & \\
\hline Rock ptarmigan & B & & & \\
\hline White-tailed ptarmigan & & & B & \\
\hline Ruffed grouse & & & B & \\
\hline Sandhill crane & & & B & \\
\hline Blackbellied plover & & B & & \\
\hline Pacific golden-plover & B & & & \\
\hline Mongolian plover & & & & B \\
\hline Semipalmated plover & & & B & \\
\hline Black oystercatcher & & & B & \\
\hline
\end{tabular}


Table 7. Continued.

\begin{tabular}{|c|c|c|c|c|}
\hline Common name & Beringian & Panboreal & North American & old World \\
\hline Greater yellowlegs & & & B & \\
\hline Lesser yellowlegs & & & b & \\
\hline Solitary sandpiper & & & B & \\
\hline Wandering tatter & B & & & \\
\hline Spotted sandpiper & & & B & \\
\hline Whimbrel & & & $b$ & \\
\hline Black tumstone & B & & & \\
\hline Surfbird & B & & & \\
\hline Semipalmated sandpiper & & & b & \\
\hline Western sandpiper & B & & & \\
\hline Least sandpiper & & & B & \\
\hline Pectoral sandpiper & B & & & \\
\hline Rock sandpiper & B & & & \\
\hline Dunlin & & & B & \\
\hline Short-billed dowitcher & & & $b$ & \\
\hline Longbilled dowitcher & b & & & \\
\hline Common snipe & & & B & \\
\hline Red-necked phalarope & & B & & \\
\hline Red phalarope & & b & & \\
\hline Parasitic jaeger & & B & & \\
\hline Long-tailed jaeger & & B & & \\
\hline Mew gull & & & B & \\
\hline Glaucous-winged gull & B & & & \\
\hline Black-legged kittiwake & & B & & \\
\hline Sabine's gull & & b & & \\
\hline Antic tern & & B & & \\
\hline Neutian tern & B & & & \\
\hline Common murre & B & & & \\
\hline Pigeon guillemot & B & & & \\
\hline Parakeet auklet & B & & & \\
\hline Least auklet & $b$ & & & \\
\hline Crested aukjet & B & & & \\
\hline Tufted puffin & B & & & \\
\hline Horned puffin & B & & & \\
\hline Great horned owl & & & B & \\
\hline Snowy owl & & B & & \\
\hline Northem hawk-ow! & & & B & \\
\hline Great gray owl & & B & & \\
\hline Shorteared owl & & B & & \\
\hline Boreal owl & & & B & \\
\hline Belted kingfisher & & & B & \\
\hline Downy woodpecker & & & B & \\
\hline Hairy woodpecker & & & $b$ & \\
\hline Three-toed woodpecker & & & B & \\
\hline Olive-sided flycatcher & & & B & \\
\hline Alder flycatcher & & & b & \\
\hline Say's pheobe & & & B & \\
\hline Horned lark & & & B & \\
\hline Tree swallow & & & B & \\
\hline Violet-green swallow & & & B & \\
\hline
\end{tabular}


Table 7. Continued.

\begin{tabular}{|c|c|c|c|c|}
\hline Common name & Beringian & Panboreal & North American & old World \\
\hline Bank swallow & & B & & \\
\hline Cliff swallow & & & B & \\
\hline Gray jay & & & B & \\
\hline Black-billed magpie & & & B & \\
\hline Common raven & & & B & \\
\hline Black-capped chickadee & & & B & \\
\hline Boreal chickadee & & & B & \\
\hline American dipper & & & B & \\
\hline Arctic warbler & B & & & \\
\hline Ruby-crowned kinglet & & & B & \\
\hline Gray-cheeked thrush & & & B & \\
\hline Swainson's thrush & & & B & \\
\hline Hermit thrush & & & B & \\
\hline American robin & & & B & \\
\hline Varied thrush & & & B & \\
\hline Yellow wagtail & B & & & \\
\hline Water pipit & B & & & \\
\hline Bohemian waxwing & & & b & \\
\hline Northern shrike & & & B & \\
\hline Orangecrowned warbler & & & B & \\
\hline Yellow warbler & & & b & \\
\hline Yellow-rumped warbler & & & B & \\
\hline Blackpoll warbler & & & B & \\
\hline Northern waterthrush & & & B & \\
\hline Wilson's warbler & & & B & \\
\hline American tree sparrow & & & B & \\
\hline Savannah sparrow & & & B & \\
\hline Fox sparrow & & & B & \\
\hline lincoln's sparrow & & & b & \\
\hline Golden-crowned sparrow & & & B & \\
\hline White-crowned sparrow & & & B & \\
\hline Darkeyed junco & & & B & \\
\hline Lapland longspur & B & & & \\
\hline Snow bunting & & B & & \\
\hline Rusty blackbird & & & B & \\
\hline Rosy finch & B & & & \\
\hline Pine grosbeak & & B & & \\
\hline Whitewinged crossbill & & & b & \\
\hline Common redpoll & & B & & \\
\hline Hoary redpoll & & B & & \\
\hline \multicolumn{5}{|l|}{ Total birds } \\
\hline \multirow[t]{2}{*}{ breeding (B) } & 31 & 21 & 67 & 2 \\
\hline & $(26 \%)$ & $(17 \%)$ & $(55 \%)$ & $(2 \%)$ \\
\hline \multirow[t]{2}{*}{ probably breeding (b) } & 2 & 3 & 14 & 0 \\
\hline & $(10 \%)$ & $(16 \%)$ & $(74 \%)$ & $(0 \%)$ \\
\hline
\end{tabular}


Table 8. Zoogeographic affinity of abundant, common, and fairly common migrants and visitants on the study area. ${ }^{2}$

\begin{tabular}{|c|c|c|c|}
\hline Common name & Beringian & Panboreal & North American \\
\hline Red-throated loon & & Aspm & \\
\hline Pacific loon & & & Aspm \\
\hline Pelagic cormorant & Aspm & & \\
\hline Tundra swan & & & $\mathrm{Cfm}$ \\
\hline Greater white-fronted goose & & & FCspm \\
\hline Emperor goose & Aspm, Afm & & \\
\hline Brant & Aspm, Afm & & \\
\hline Canada goose & & & Cspm, Afm \\
\hline Green-winged teal & & & Aspm \\
\hline Malland & & Cspm, Clm & \\
\hline Northern pintail & & Aspm, Afm & \\
\hline American wigeon & & & Cspm, FCfm \\
\hline Greater scaup & Aspm & & \\
\hline King eider & & Aspm & \\
\hline Steller's eider & Cspm, FCv, Afm & & \\
\hline Harlequin duck & $\mathrm{Av}$ & & \\
\hline Oldsquaw & & Aspm & \\
\hline Black scoter & Aspm & & \\
\hline Surf scoter & & Cspm & \\
\hline Whitewinged scoter & & & Cspm, Cfm \\
\hline Common goldeneye & & & FCspm \\
\hline Sandhill crane & & & $\mathrm{Afm}$ \\
\hline Black bellied plover & & Cspm, Cfm & \\
\hline Pacific golden-plover & $\mathrm{Cfm}$ & & \\
\hline Spotted sandpiper & & & $\mathrm{FCfm}$ \\
\hline Whimbrel & & & $\mathrm{Cfm}$ \\
\hline Bar-tailed godwit & FCfm & & \\
\hline Sanderling & & $\mathrm{Cfm}$ & \\
\hline Western sandpiper & $\mathrm{Afm}$ & & \\
\hline Least sandpiper & & & FCfm \\
\hline Rock sandpiper & Cspm, Afm & & \\
\hline Dunlin & & & $\mathrm{Cfm}$ \\
\hline Shortbilled dowitcher & & & $\mathrm{Cfm}$ \\
\hline Long-billed dowitcher & $\mathrm{Cfm}$ & & \\
\hline Red-necked phalarope & & $\mathrm{Afm}$ & \\
\hline Parzsitic jzeger & & Av & \\
\hline long-tailed jaeger & & $\mathrm{Cv}$ & \\
\hline Mew gull & & & Cspm \\
\hline Tree swallow & & & Cspm \\
\hline Water pipit & $\mathrm{Cfm}$ & & \\
\hline Savannah sparrow & & & Cfm \\
\hline Golden-crowned sparrow & & & Cfm \\
\hline Lapland longspur & Aspm, Afm & & \\
\hline Snow bunting & & $\mathrm{Cspm}, \mathrm{Cfm}$ & \\
\hline \multicolumn{4}{|l|}{ Totals } \\
\hline \multirow[t]{2}{*}{ migrants } & 13 & 10 & 18 \\
\hline & $(13 \%)$ & $(24 \%)$ & $(44 \%)$ \\
\hline \multirow[t]{2}{*}{ visitants } & 1 & 2 & 0 \\
\hline & $(33 \%)$ & $(37 \%)$ & $(0 \%)$ \\
\hline
\end{tabular}

A - abundant; C - common; FC - fairly common; spm = spring migrant; $f m=$ fall migrant; $v$ * visitant. 
Breeding birds in coastal areas show a different distribution of zoogeographical affinities than those nesting inland (Table 9). Of 37 species that breed only in coastal areas, $51.4 \%$ are Beringian (e.g., common murre, Aleutian tern, tufted puffin), whereas most of the 59 species nesting only inland are of North American affinity (e.g., gray-cheeked thrush, northern waterthrush, American tree sparrow).

As along the Alaska Peninsula (Gill et al. 1981), the Beringian group accounts for a high biomass and number of avian forms migrating through nearshore and littoral habitats (e.g., emperor goose, brant, common eider, rock sandpiper, western sandpiper). In addition, several avian forms in the Panboreal and North American groups account for large numbers and high biomass during migration (e.g., king eider, surf scoter, white-winged scoter). The preponderance of forms migrating along the coast, however, are of the Beringian group.

Of the 185 species found in our study area, $140(76 \%)$ nested or probably nested there. A similar proportion of species was found breeding (82\% of 62; Williamson 1957) to the north and west near Napaskiak, and to the east near Iliamna Lake (78\% of 103; Williamson and Peyton 1962). However, both those studies were conducted at more inland locations either from May to June or in May, June, and August, and as a result, probably excluded many migrants and winter visitants; thus, they were biased toward locally breeding species. A study more comparable to ours, which included spring, summer, fall, and winter observations at both littoral and inland locations, was conducted by Gill et al. (1981) on the north-central Alaska Peninsula. They found only 49\% (61 of 125) breeding or probably breeding species, a proportion much lower than the $76 \%$ found by our study. We conclude that the relatively high proportion of nesting or probably nesting spccies on our study area reflects a wider diversity of habitats.

Table 9. Zoogeographic affinity of species or presumed subspecies breeding or probably breeding on the study area.

\begin{tabular}{|c|c|c|c|c|}
\hline $\begin{array}{l}\text { Number of species or } \\
\text { subspecies breeding }\end{array}$ & Beringian & Panboreal & North American & old World \\
\hline \multicolumn{5}{|c|}{ Ahklun or Kilbuck mountains } \\
\hline$(N=60)$ & $\begin{array}{c}5 \\
8.3 \%\end{array}$ & $\begin{array}{c}4 \\
6.7 \%\end{array}$ & $\begin{array}{c}50 \\
83.3 \%\end{array}$ & $\begin{array}{c}1 \\
1.7 \%\end{array}$ \\
\hline$(N-38)$ & $\begin{array}{c}20 \\
52.6 \%\end{array}$ & $\begin{array}{c}\text { stal area o } \\
9 \\
23.7 \%\end{array}$ & $\begin{array}{c}8 \\
21.0 \%\end{array}$ & $\begin{array}{c}1 \\
2.6 \%\end{array}$ \\
\hline \multicolumn{5}{|c|}{ Mountain and coastal areas } \\
\hline$(N=42)$ & $\begin{array}{c}8 \\
19.0 \%\end{array}$ & $\begin{array}{c}11 \\
26.2 \%\end{array}$ & $\begin{array}{c}23 \\
54.8 \%\end{array}$ & $\begin{array}{c}0 \\
0.0 \%\end{array}$ \\
\hline
\end{tabular}


Generally, the abundance of most breeding or probably breeding species was similar throughout the areas where they were recorded on our study area (Table 10). Exceptions included the rough-legged hawk (rare in the Kilbuck Mountains and common on the coastal plain), the least sandpiper (rare in the Kilbuck Mountains and uncommon in the Ahklun Mountains), and the white-crowned sparrow (abundant in the Kilbuck Mountains, uncommon in the Ahklun Mountains, and rare on the coastal plain). The proportion of breeding or suspected breeding birds was similar in all areas (Table 11), except at sea cliffs and on islands where $68 \%$ (19 of 28 ) of the species were abundant to fairly common. Fifty to $59 \%$ of the breeders were abundant to fairly common in the Kilbuck and Ahklun mountains and coastal plain. This higher proportion of abundant-

Table 10. Distribution and abundance of breeding or suspected breeding birds. ${ }^{2}$

\begin{tabular}{|c|c|c|c|c|}
\hline Common name & $\begin{array}{c}\text { Kilbuck } \\
\text { Mountains }\end{array}$ & $\begin{array}{c}\text { Ahklun } \\
\text { Mountains }\end{array}$ & $\begin{array}{l}\text { Sea cliffs } \\
\text { and islands }\end{array}$ & $\begin{array}{c}\text { Coastal } \\
\text { plain }\end{array}$ \\
\hline Red-throated loon & FC & FC & & FC \\
\hline Pacific loon & & $\mathbf{R}$ & & $\mathbf{R}$ \\
\hline Common loon & & $\mathrm{U}$ & & \\
\hline Fork-tailed storm-petrel & & & $\mathbf{R}$ & \\
\hline Doublecrested cormorant & & & FC & \\
\hline Pelagic cormorant & & & $\Lambda$ & \\
\hline Red-faced cormorant & & & $\mathbf{R}$ & \\
\hline Tundra swan & & & & U \\
\hline Greater whitefronted goose & $\mathbf{R}$ & & & \\
\hline Emperor goose & & & & $\mathbf{R}$ \\
\hline Brant & & & & $\mathbf{R}$ \\
\hline Canada goose & $\mathrm{u}$ & $\mathrm{U}$ & & $\mathrm{U}$ \\
\hline Green-winged teal & C & c & & C \\
\hline Mallard & $\mathbf{R}$ & $\mathbf{R}$ & & $\mathbf{R}$ \\
\hline Northern pintail & C & c & & c \\
\hline American wigeon & $\mathbf{U}$ & $\mathrm{U}$ & & \\
\hline Greater scaup & $\mathrm{U}$ & U & & $\mathbf{u}$ \\
\hline Common eider & & & c & \\
\hline King eider & & & VR & VR \\
\hline Harlequin duck & A & A & & \\
\hline Oldsquaw & & c & & \\
\hline Black scoter & & & & U \\
\hline Surf scoter & & VR & & \\
\hline White-winged scoter & & $\mathbf{R}$ & & \\
\hline Common goldeneye & C & $\mathrm{C}$ & & \\
\hline Bufflehead & VR & $\mathbf{R}$ & & \\
\hline Common merganser & $\mathbf{R}$ & $\mathbf{R}$ & & \\
\hline Red-breasted merganser & C & c & & c \\
\hline Osprey & VR & & & \\
\hline Bald eagle & $\mathrm{U}$ & $\mathbf{U}$ & $\mathbf{U}$ & \\
\hline Northern harrier & $\mathrm{U}$ & & & \\
\hline Northern goshawk & c & & & \\
\hline Red-tailed hawk & VR & & & \\
\hline
\end{tabular}


Table 10. Continued.

\begin{tabular}{|c|c|c|c|c|}
\hline Common name & $\begin{array}{c}\text { Kilbuck } \\
\text { Mountains }\end{array}$ & $\begin{array}{c}\text { Ahklun } \\
\text { Mountains }\end{array}$ & $\begin{array}{l}\text { Sea cliffs } \\
\text { and islands }\end{array}$ & $\begin{array}{c}\text { Coastal } \\
\text { plain }\end{array}$ \\
\hline Rough-legged hawk & $\mathbf{R}$ & & c & \\
\hline Golden eagle & C & C & & \\
\hline American kestrel & VR & & & \\
\hline Merlin & $\mathbf{U}$ & & & \\
\hline Peregrine falcon & VR & & VR & \\
\hline Gyrfalcon & C & & $\mathrm{C}$ & \\
\hline Spruce grouse & U & $\mathrm{U}$ & & \\
\hline Willow ptarmigan & FC & FC & & FC \\
\hline Rock ptarmigan & $\mathrm{U}$ & $\mathrm{u}$ & & $\mathrm{v}$ \\
\hline White-tailed ptarmigan & & VR & & \\
\hline Ruffed grouse & $\mathbf{R}$ & & & \\
\hline Sandhill crane & & & & $\mathbf{A}$ \\
\hline Blackbellied plover & & U & & C \\
\hline Pacific golden-plover & & $\mathbf{R}$ & & $\mathbf{R}$ \\
\hline Mongolian ploves & & & & VR \\
\hline Semipalmated plover & $A$ & A & & $A$ \\
\hline American black oystercatcher & & & VR & \\
\hline Greater yellowlegs & $A$ & $A$ & & \\
\hline Lesser yellowlegs & $\mathrm{u}$ & $\mathrm{u}$ & & \\
\hline Solitary sandpiper & $\mathrm{u}$ & & & \\
\hline Wandering tattler & FC & FC & & \\
\hline Spotted sandpiper & $A$ & $A$ & & \\
\hline Whimbrel & & & & $\mathbf{R}$ \\
\hline Black turnstone & & & & u \\
\hline Surfbird & FC & FC & & \\
\hline Semipalmated sandpiper & & & & $\mathbf{R}$ \\
\hline Western sandpiper & $A$ & A & & $\mathbf{A}$ \\
\hline Least sandpiper & $\mathbf{R}$ & $\mathrm{U}$ & & \\
\hline Pectoral sandpiper & & & & VR \\
\hline Rock sandpiper & & & $A$ & $A$ \\
\hline Dunlin & & & & C \\
\hline Short-billed dowitcher & & & & $\mathbf{R}$ \\
\hline Longbilled dowitcher & & & & $\mathbf{R}$ \\
\hline Common snipe & c & C & & C \\
\hline Red-necked phalarope & C & C & & C \\
\hline Red phalarope & & & & VR \\
\hline Parasitic jaeger & & & & C \\
\hline Long-tailed jaeger & & & & $\mathbf{R}$ \\
\hline Mew gull & C & C & & C \\
\hline Glaucous-winged gull & & & $A$ & \\
\hline Black-legged kittiwake & & & A & \\
\hline Sabine's gull & & & & $\mathbf{R}$ \\
\hline Arctic tern & $A$ & A & & $\boldsymbol{A}$ \\
\hline Aleutian tern & & & & C \\
\hline Common murre & & & A & \\
\hline Pigeon guillemot & & & c & \\
\hline Parakeet auklet & & & C & \\
\hline Least auklet & & & VR & \\
\hline Crested auklet & & & VR & \\
\hline Tufted puffin & & & $A$ & \\
\hline
\end{tabular}


Table 10. Continued.

\begin{tabular}{|c|c|c|c|c|}
\hline Common name & $\begin{array}{c}\text { Kilbuck } \\
\text { Mountains }\end{array}$ & $\begin{array}{l}\text { Ahklun } \\
\text { Mountains }\end{array}$ & $\begin{array}{c}\text { Sea cliffs } \\
\text { and islands }\end{array}$ & $\begin{array}{c}\text { Coastal } \\
\text { plain }\end{array}$ \\
\hline Homed puffin & & & c & \\
\hline Great homed owl & c & & & \\
\hline Snowy owl & & & & $\mathbf{R}$ \\
\hline Northern hawk-owl & $\mathbf{U}$ & & & \\
\hline Great gray owl & $\mathbf{R}$ & & & \\
\hline Shorteared owl & & & & $\mathbf{R}$ \\
\hline Boreal owl & $\mathbf{R}$ & & & \\
\hline Belted kingfisher & C & & & \\
\hline Downy woodpecker & $\mathbf{R}$ & & & \\
\hline Hairy woodpecker & VR & & & \\
\hline Threetoed woodpecker & $\mathrm{v}$ & & & \\
\hline Olivesided flycatcher & $\mathrm{u}$ & & & \\
\hline Ader flycatcher & $\mathbf{R}$ & & & \\
\hline Say's pheobe & VR & & & \\
\hline Horned lark & U & $\mathbf{U}$ & & \\
\hline Tree swallow & $A$ & $A$ & & $A$ \\
\hline Violet-green swallow & U & & & \\
\hline Bank swallow & c & C & & c \\
\hline Cliff swallow & $\boldsymbol{A}$ & $\boldsymbol{A}$ & & $\mathbf{R}$ \\
\hline Gray jay & $\mathbf{A}$ & $A$ & & \\
\hline Blackbilled magpie & $\mathbf{R}$ & $\mathbf{R}$ & & \\
\hline Common raven & $A$ & $A$ & $A$ & \\
\hline Black-capped chickadee & C & C & & \\
\hline Boreal chickadee & $A$ & & & \\
\hline American dipper & $A$ & U & & $\mathbf{R}$ \\
\hline Anctic warbler & C & C & & \\
\hline Ruby-crowned kinglet & C & & & \\
\hline Gray cheeked thrush & $A$ & $A$ & $A$ & $A$ \\
\hline Swainson's thrush & $\mathrm{C}$ & $\mathrm{U}$ & & \\
\hline Hermit thrush & U & U & U & \\
\hline American robin & $\mathbf{A}$ & FC & & FC \\
\hline Varied thrush & $\mathbf{A}$ & $\mathbf{R}$ & & \\
\hline Yellow wagtail & $A$ & $A$ & $A$ & $A$ \\
\hline Water pipit & $\Lambda$ & $A$ & $A$ & $A$ \\
\hline Bohemian waxwing & $\mathbf{R}$ & & & \\
\hline Northern shrike & U & & & \\
\hline Orangecrowned warbler & FC & FC & & \\
\hline Yellow warbler & $\mathbf{R}$ & $\mathbf{R}$ & VR & $\mathbf{R}$ \\
\hline Yellow-rumped wastler & FC & & & \\
\hline 8lackpoll warbler & FC & & & \\
\hline Northern waterthrush & $A$ & $\mathrm{U}$ & & \\
\hline Wilson's warbler & $\mathbf{A}$ & $A$ & & $\mathrm{FC}$ \\
\hline American tree sparrow & C & C & & \\
\hline Savannah sparrow & $A$ & $A$ & $A$ & $\boldsymbol{A}$ \\
\hline Fox sparrow & c & C & c & c \\
\hline Lincoln's sparrow & $\mathbf{R}$ & & & \\
\hline Golden crowned sparrow & $A$ & c & & $A$ \\
\hline Whitecrowned sparrow & $A$ & $\mathrm{u}$ & & $\mathbf{R}$ \\
\hline Darkeyed junco & $\mathrm{U}$ & & & \\
\hline Lapland longspur & $A$ & $A$ & $A$ & $\Lambda$ \\
\hline Snow bunting & $A$ & $A$ & $A$ & \\
\hline Rusty blackbird & $\mathrm{U}$ & & & \\
\hline Rosy finch & FC & FC & FC & \\
\hline
\end{tabular}


Table 10. Continued.

\begin{tabular}{lcccc}
\hline Common name & $\begin{array}{c}\text { Kilbuck } \\
\text { Mountains }\end{array}$ & $\begin{array}{c}\text { Ahklun } \\
\text { Mountains }\end{array}$ & $\begin{array}{c}\text { Sea cliffs } \\
\text { and islands }\end{array}$ & $\begin{array}{c}\text { Coastal } \\
\text { plain }\end{array}$ \\
\hline $\begin{array}{l}\text { Pine grosbeak } \\
\text { White-winged crossbill }\end{array}$ & $\mathrm{U}$ & & & \\
Common redpoll & $\mathrm{R}$ & & & \\
Hoary redpoll & $\mathrm{A}$ & $\mathrm{A}$ & & $\mathrm{A}$ \\
\hline
\end{tabular}

A - abundant; C = common; FC - fairly common; U - uncommon; R - rare; VR - very rare.

to-fairly-common breeding or suspected breeding birds at sea cliffs and islands reflects the dominance of colonial seabirds and the low diversity of nesting habitats there.

Forty-five of $140(32 \%)$ species that nested or were thought to nest in our area were abundant-to-fairly-common and were more or less widespread (both mountain ranges or entire area; Table 11). Another $18(13 \%)$ species were widespread but were generally uncommon to very rare. Twenty-four ( $36 \%$ of 67 ) of the uncommon-to-very-rare species nested only in the Kilbuck Mountains, 3 (4\%) were found mainly or entirely in the Ahklun Mountains, and $22(33 \%)$ were found only on the coastal plain or on cliffs and islands (Table 4). These apparently restricted distributions might in part result from our surveying very few of the preferred nesting and foraging habitats; very restricted distribution of preferred habitats of the species (e.g., sea cliffs); preferred habitats being man-made (e.g., mining tailings) and thus localized; or combinations of two or more of those factors.

Widespread and abundant-to-fairly-common breeding birds were most frequently associated with shrub habitats, dwarf shrub mat habitats, or freshwater habitats (Tables 12-19). These are ecologically widespread

Table 11. Number of breeding or probably breeding birds by primary nesting area.

\begin{tabular}{lcc}
\hline Primary nesting area & $\begin{array}{c}\text { Abundant to fairly } \\
\text { common }\end{array}$ & $\begin{array}{c}\text { Uncommon to very } \\
\text { rare }\end{array}$ \\
\hline Kilbuck Mountains & 8 & 24 \\
Ahklun Mountains & 4 & 3 \\
Both mountain ranges & 14 & 7 \\
Coastal areas & 16 & 22 \\
Entire area & 31 & 11 \\
Total & & 67 \\
\hline
\end{tabular}


Table 12. Lacustrine and fluviatile habitats used by birds in the Kilbuck and Ahklun mountain region. $B=$ breeding; $b=$ probably breeding; $f=$ feeding; $r=$ roosting; $x=$ preferred habitats during migration or during the nonbreeding season.

\begin{tabular}{lcllc}
\hline \multicolumn{2}{c}{ Lacustrine waters and shorelines } & & \multicolumn{2}{c}{ Fluviatile waters and shorelines } \\
\hline Common name & Status & Common name & Status \\
\hline Red-throated loon & B & Doublecrested cormorant & f \\
Pacific loon & B & Canada goose & B \\
Common loon & b & Green-winged teal & f \\
Horned grebe & x & Mallard & f \\
Red-necked grebe & x & Northern pintail & f \\
Tundra swan & x & American wigeon & f \\
Green-winged teal & f & Harlequin duck & B \\
Baikal teal & x & Common goldeneye & B \\
Mallard & F & Bufflehead & B \\
Northern pintail & f & Common merganser & B \\
Northern shoveler & f & Red-breasted merganser & B \\
American wigeon & f & Osprey & B \\
Greater scaup & x & Semipalmated plover & B \\
Oldsquaw & x & Lesser yellowlegs & b \\
Red-breasted merganser & B & Solitary sandpiper & B \\
Semipalmated plover & B & Wandering tattler & B \\
Greater yellowlegs & B & Ruddy turnstone & x \\
Lesser yellowlegs & x & Mew gull & B \\
Solitary sandpiper & x & Glaucous-winged gull & f \\
Terek sandpiper & x & Arctic tern & B \\
Semipalmated sandpiper & b & Belted kingfisher & f \\
Shortbilled dowitcher & b & Tree swallow & f \\
Longbilled dowitcher & b & Violet-green swallow & f \\
Red-necked phalarope & B & Bank swallow & f \\
Red phalarope & b & Cliff swallow & f \\
South Polar skua & x & American dipper & B \\
Bonaparte's gull & f & Yellow wagtail & f \\
Mew gull & B & Rusty blackbird & \\
Black-tegged kittiwake & f & & \\
Arctic tern & B & & \\
Tree swallow & f & & \\
Violet-green swallow & f & & \\
Bank swallow & f & & \\
Yellow wagtail & f & & \\
\hline
\end{tabular}


Table 13. Nearshore and inshore habitats used by birds in the Kilbuck and Ahklun mountain region. $B=$ breeding; $b=$ probably breeding; $f=$ feeding; $r=$ roosting; $x=$ preferred habitats during migration or during the nonbreeding season.

\begin{tabular}{|c|c|c|c|}
\hline \multicolumn{2}{|c|}{ Nearshore waters } & \multicolumn{2}{|l|}{ Inshore waters } \\
\hline Common name & Status & Common name & Status \\
\hline Red-throated loon & $\mathbf{x}$ & Red-throated loon & $x$ \\
\hline Pacific loon & $\mathbf{x}$ & Pacific loon & $\mathbf{x}$ \\
\hline Common loon & $r$ & Common loon & $x$ \\
\hline Short-tailed shearwater & $\mathbf{x}$ & Homed grebe & $\mathbf{x}$ \\
\hline Double-crested cormorant & f & Red-necked grebe & $\mathrm{x}$ \\
\hline Greater white-fronted goose & $\mathbf{x}$ & Short-tailed shearwater & $\mathbf{x}$ \\
\hline Emperor goose & $\mathbf{f}$ & Doublecrested cormorant & f \\
\hline Brant & $x$ & Pelagic cormorant & f \\
\hline Canada goose & $x$ & King eider & $\mathbf{x}$ \\
\hline Green-winged teal & $x$ & Steller's eider & f \\
\hline Mallard & $\mathbf{x}$ & Harlequin duck & f \\
\hline Redhead & $\mathbf{x}$ & Oldsquaw & $\mathbf{x}$ \\
\hline Greater scaup & $f$ & Surf scoter & f \\
\hline Common eider & $x$ & White-winged scoter & f \\
\hline Steller's eider & $\mathbf{r}$ & Redbreasted merganser & $x$ \\
\hline Oldsquaw & $\mathbf{x}$ & Pomarine jaeger & $\mathrm{x}$ \\
\hline Black scoter & f & Common murre & $\mathbf{x}$ \\
\hline Surf scoter & $\mathbf{x}$ & Thick-billed murre & $\mathrm{x}$ \\
\hline Common goldeneye & $x$ & Pigeon guillemot & $x$ \\
\hline Barrow's goldeneye & $\mathbf{x}$ & Marbled murrelet & f \\
\hline Bufflehead & f & Parakeet auklet & $\mathrm{x}$ \\
\hline Red-breasted merganser & f & Least auklet & $\mathrm{x}$ \\
\hline Black-bellied plover & $\mathbf{x}$ & Crested auklet & $\mathbf{x}$ \\
\hline Whimbrel & $\mathbf{x}$ & Tufted puffin & $\mathrm{x}$ \\
\hline Bristle-thighed curlew & $\mathbf{x}$ & Horned puffin & $\mathbf{x}$ \\
\hline Hudsonian godwit & f & & \\
\hline Bar-tailed godwit & $\mathbf{x}$ & & \\
\hline Baird's sandplper & $\mathbf{x}$ & & \\
\hline Pectoral sandpiper & $\mathrm{x}$ & & \\
\hline Rock sandpiper & $\mathbf{f}$ & & \\
\hline Dunlin & $x$ & & \\
\hline Red-necked phalarope & $\mathrm{x}$ & & \\
\hline Red phalarope & $\mathrm{x}$ & & \\
\hline Pomarine jaeger & $\mathrm{x}$ & & \\
\hline Bonaparte's gull & $r, \bar{x}$ & & \\
\hline Slatybacked gull & $\mathrm{x}$ & & \\
\hline Glaucous-winged gull & $\mathbf{f , r}$ & & \\
\hline Glaucous gull & $r$ & & \\
\hline Sabine's gull & $\mathbf{r}$ & & \\
\hline Arctic tern & $f, r$ & & \\
\hline Bank swallow & f & & \\
\hline
\end{tabular}




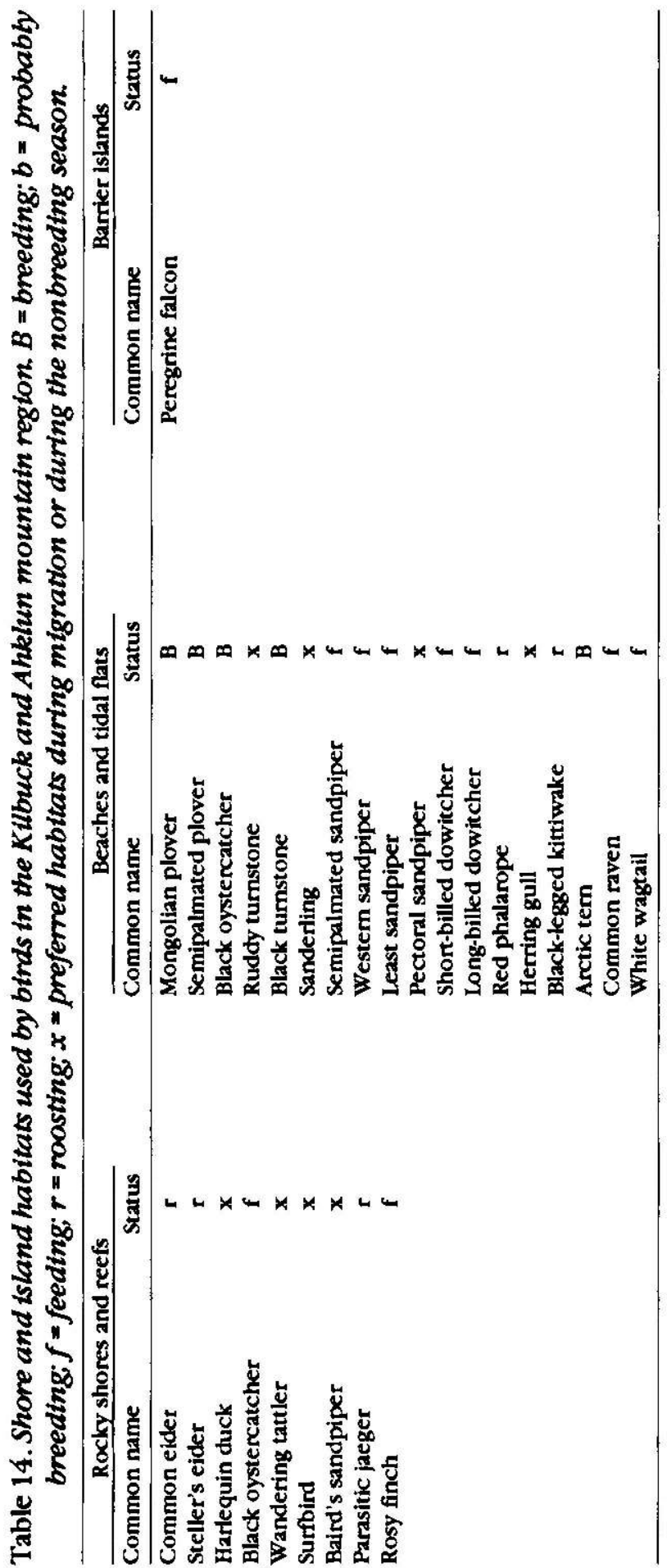




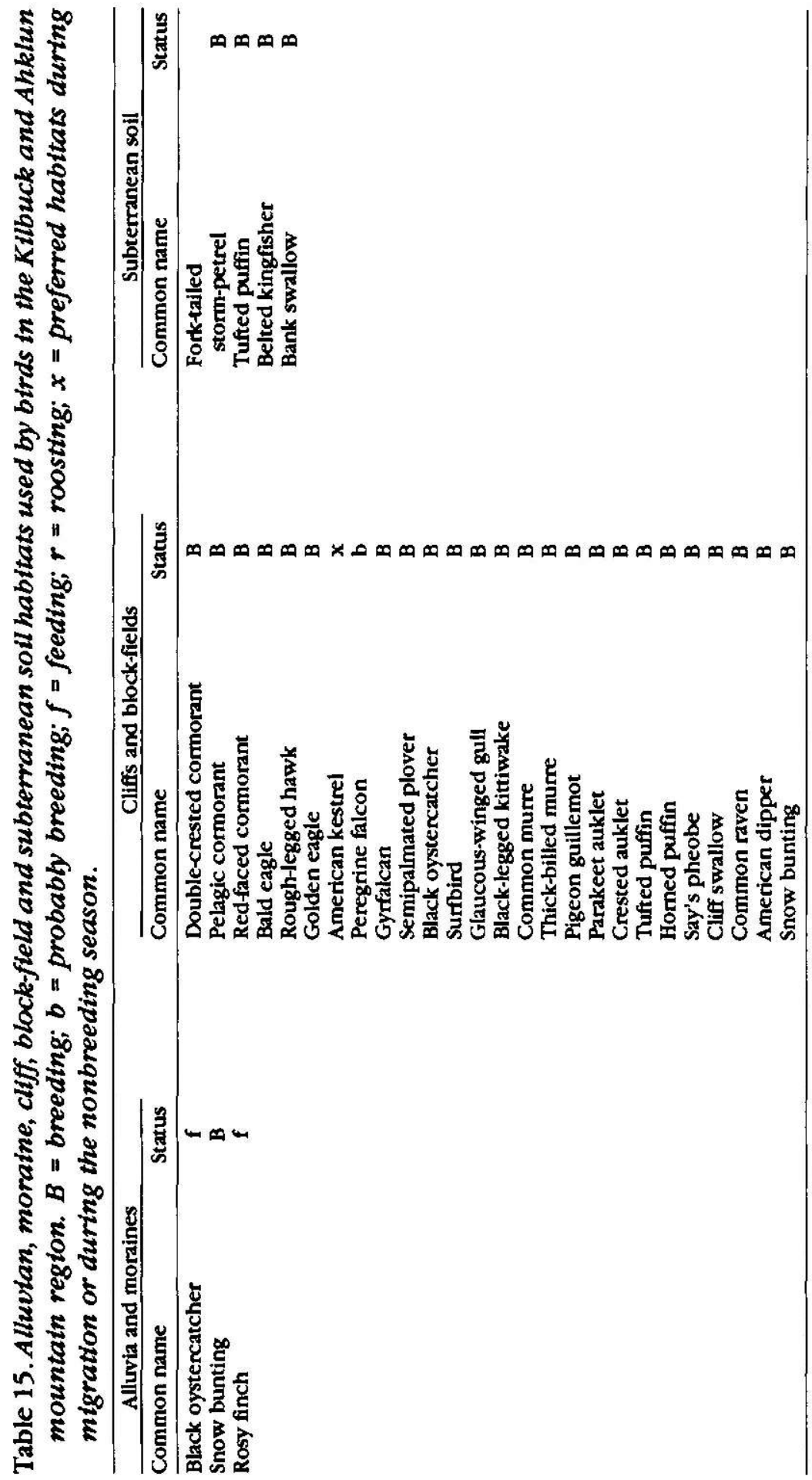




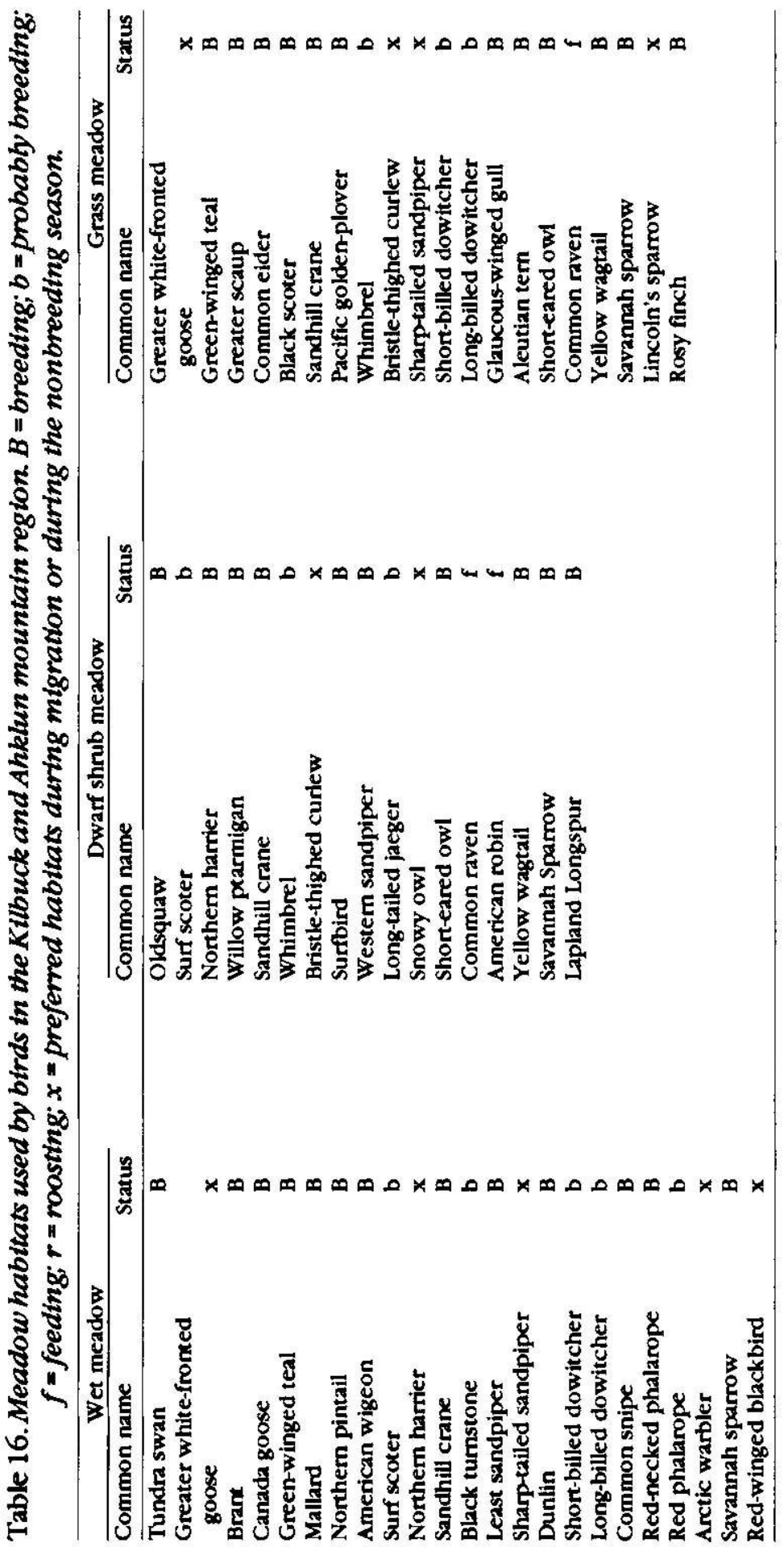


Table 17. Shrub habitats used by birds in the Kilbuck and Ahklun mountain region. $B=$ breeding; $b=$ probably breeding; $f=$ feeding; $r=$ roosting; $x$ = preferred habitats during migration or during the nonbreeding season.

\begin{tabular}{|c|c|c|c|}
\hline \multicolumn{2}{|c|}{ Dwarf shrub mat } & \multicolumn{2}{|c|}{ Low, medium, and tall shrub thicket } \\
\hline Common name & Status & Common name & Status \\
\hline Emperor goose & f & Greater whitefronted goose & $\mathbf{x}$ \\
\hline King eider & B & Canada goose & B \\
\hline Rough-legged hawk & B & Green-winged teal & B \\
\hline Golden eagle & B & Mallard & B \\
\hline Gyrfalcon & f & Northern pintail & B \\
\hline Spruce grouse & f & American wigeon & B \\
\hline Willow ptarmigan & B & Northern harrier & B \\
\hline Rock ptarmigan & B & Merlin & B \\
\hline White-tailed ptamigan & B & Gyrfalcon & f \\
\hline Black-bellied plover & B & Spruce grouse & B \\
\hline Spotted sandpiper & $\mathbf{x}$ & Willow ptarmigan & B \\
\hline Bristle-thighed curlew & $\mathbf{x}$ & Rock ptarmigan & $\mathbf{8}$ \\
\hline Western sandpiper & B & Boreal owl & f \\
\hline Rock sandpiper & B & Downy woodpecker & f \\
\hline Parasitic jaeger & B & Alder flycatcher & b \\
\hline Longtailed jaeger & b & Cliff swallow & $f$ \\
\hline Aleutian tern & B & Gray jay & B \\
\hline Snowy owl & $x$ & Common raven & B \\
\hline Hairy woodpecker & $\mathbf{x}$ & Black-capped chickadee & $B, f$ \\
\hline Horned lark & B & Arctic warbler & B \\
\hline Hermit thrush & B & Ruby-crowned kinglet & f \\
\hline Water pipit & B & Gray-cheeked thrush & $\mathbf{B}$ \\
\hline Northern waterthrush & B & Swainson's thrush & B \\
\hline Golden-crowned sparrow & $f$ & Hermit thrush & B \\
\hline Lapland longspur & B & American robin & f \\
\hline Rosy finch & B & Varied thrush & $x$ \\
\hline \multirow[t]{16}{*}{ Common redpoll } & f & Bohemian waxwing & f \\
\hline & & Northern shrike & B \\
\hline & & Orange-crowned warbler & B \\
\hline & & Yellow warbler & b \\
\hline & & Yellow-rumped warbler & B \\
\hline & & Blackpoll warbler & B \\
\hline & & Northern waterthrush & B \\
\hline & & Wilson's warbler & B \\
\hline & & American tree spasrow & B \\
\hline & & Savannah sparrow & B \\
\hline & & Fox sparrow & B \\
\hline & & Lincoln's sparrow & $\mathbf{x}$ \\
\hline & & Golden-crowned sparrow & B \\
\hline & & Whitecrowned sparrow & B \\
\hline & & Pine grosbeak & f \\
\hline & & White-winged crossbill & f \\
\hline
\end{tabular}


Table 17. Continued.

\begin{tabular}{|c|c|c|c|}
\hline \multicolumn{2}{|c|}{ Dwarf shrub mat } & \multicolumn{2}{|c|}{ Low, medium, and tall shrub thicket } \\
\hline Common name & Status & Common name & Status \\
\hline & & Common redpolf & B \\
\hline & & Hoary redpoll & B \\
\hline
\end{tabular}

birds of wetlands, typical tundra habitats, thicket and forest habitats, or coastal cliffs. On our study area, most of the widespread but uncommonto-very-rare species used wetlands or rivers, dwarf shrub mat other alpine habitats, or thickets or open forests.

Thirty-one species were normally associated with thicket and forest habitats in the Kilbuck Mountains, of which only $18(58 \%)$ were found in the Ahklun Mountains. This reduction with distance into the taigatundra ecotone was predictable but might have been exaggerated by limited fieldwork in the woodlands of the Ahklun Mountains. However, of the 51 common species of the interior Alaska-Tanana valley taiga (Spindler and Kessel 1980), $46(90 \%)$ nested or probably nested in the Kilbuck Mountains, whereas only 21 (41\%) nested in the Ahklun Mountains. These taiga species were $53 \%$ of all breeding or probably breeding species in the Kilbuck Mountains, and $28 \%$ of all breeding or probably breeding species in the Ahklun Mountains.

Twenty-eight species nested both at Napaskiak and within our study area. Of those 28 species, Williamson (1957) suggested that 6 species (21\%) penetrated the taiga-tundra ecotone in the lower Kuskokwim River area to only a limited extent, $50 \%$ penetrated the ecotone somewhat further, and $29 \%$ occurred throughout the ecotone. Our data for the same 28 species agree with Williamson (1957), although we found some species penetrating the ecotone farther (e.g., common redpoll). A complication in our area was that some species (e.g., Bonaparte's gull) occurred in a separate taiga-tundra ecotone at the Togiak River (which extended west from the Wood River-Tikchik River area woodlands) as well as in the main taiga-tundra ecotone extending south and east from the Kuskokwim River area. Still other species were rare or absent in our upland area, but Williamson (1957) found them common in the taigatundra ecotone in the Kuskokwim River lowlands (e.g., black scoter).

Twenty-two species of the thickets and forests in our area were not recorded in the same ecotone by Williamson (1957), and some of these were sufficiently widespread to be characteristic of our taiga-tundra ecotones (e.g., golden eagle, arctic warbler). Most of these 22 species were restricted to the extreme interior of the ecotone or fluctuated 


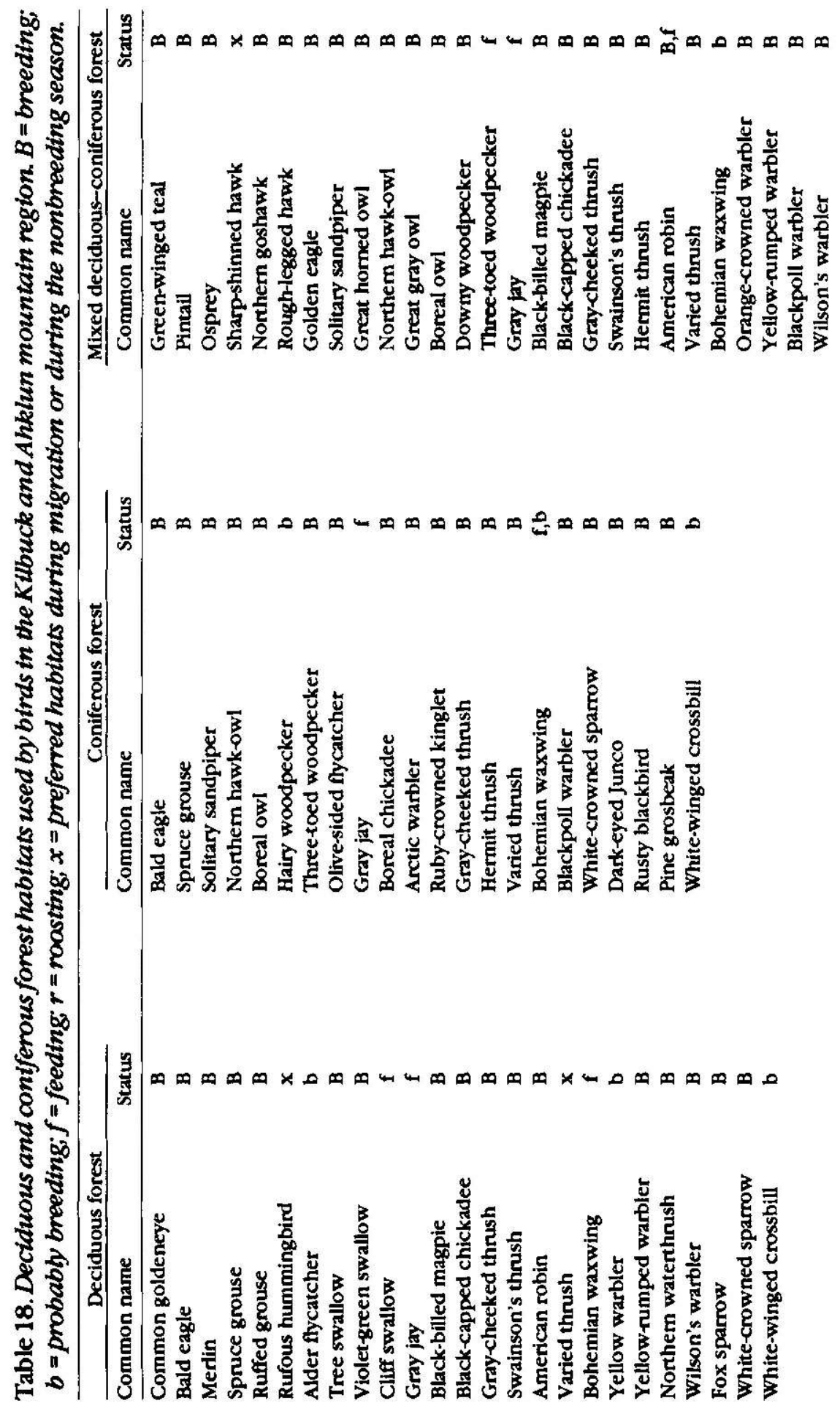




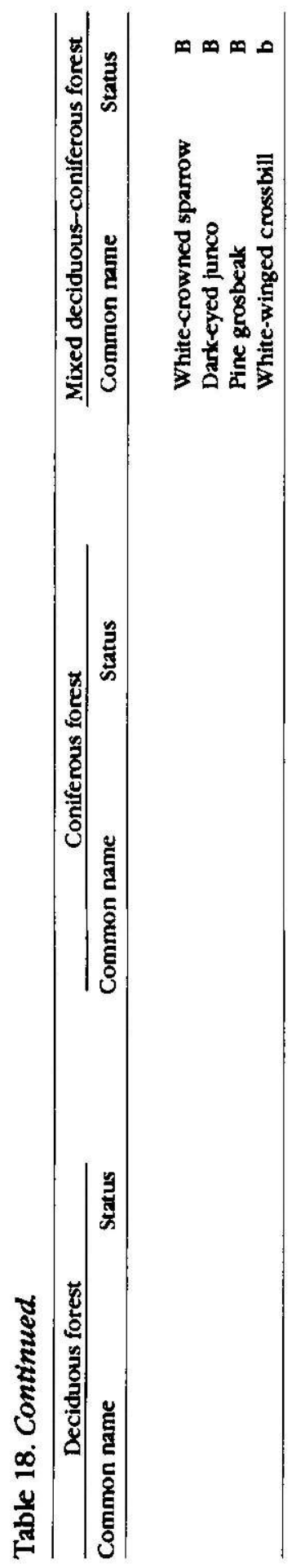


Table 19. Scattered woodland, dwarfforest and artificial habitats used by birds in the Kilbuck and Ahklun mountain region. $B=$ breeding; $b=$ probably breeding; $f=$ feeding; $r=$ roosting; $x=$ preferred habitats during migration or during the nonbreeding season.

\begin{tabular}{lclc}
\hline \multirow{2}{*}{ Scattered woodland and dwarf forest } & & \multicolumn{2}{c}{ Artificial habitats } \\
\cline { 4 - 4 } Common name & Status & Common name & Status \\
\hline \multirow{3}{*}{ Golden eagle } & f & Rough-legged hawk & B \\
Northern flicker & X & Golden eagle & B \\
Bohemian waxwing & b & Wandering tattler & B \\
Northem shrike & B & Spotted sandpiper & B \\
American tree sparrow & B & Parasitic jaeger & f \\
Whitecrowned sparrow & B & Hairy woodpecker & f \\
& & Threetoed woodpecker & f \\
& & Say's pheobe & B \\
& & Tree swallow & B \\
& & Violet-green swallow & B \\
& & Cliff swallow & B \\
& Gray jay & f \\
& American dipper & B \\
& & American robin & B \\
& & Snow bunting & B \\
& & Rusty blackbird & f \\
\hline
\end{tabular}

greatly in number among years. Many of these species extend only sparsely into the taiga-tundra ecotones in western Alaska (Gabrielson and Lincoln 1959; Kessel and Gibson 1978), and some occurted so rarely and intermittently in the Kilbuck Mountains (e.g., peregrine falcon, Say's phoebe, Bohemian waxwing) that they might have been missed in less prolonged surveys.

The 22 species that used dwarf shrub mats, dwarf shrub meadows, or small lacustrine ponds included some species characteristic of riparian lowland habitats (e.g., savannah sparrow, common redpoll). However, most were waterfowl or shorebirds that were restricted to lowlands or were ecologically widespread. Another six species (e.g., hoary redpoll, red phalarope) were very local or rare in parts of the littoral plain, and two species (emperor goose, brant) nested only on the coast in areas with slight relief. In general, most of those birds that used dwarf shrub habitats and ponds at lower elevations were species typical of the Yukon-Kuskokwim Delta.

We found differences in timing between some of the same species nesting at different altitudes and latitudes but not for others. Some species 
Table 20. Change in density or numbers of spectes in response to mining activities.

\begin{tabular}{|c|c|c|}
\hline $\begin{array}{l}\text { Increased densities } \\
\text { or numbers } \\
\end{array}$ & $\begin{array}{c}\text { Decreased densities } \\
\text { of numbers }\end{array}$ & No change \\
\hline Common name & Common name & Common name \\
\hline Ruffed grouse & Downy woodpecker & American robin \\
\hline Semipalmated plover & Threetoed woodpecker & Orangecrowned warbler \\
\hline Wandering tattler & Olive-sided flycatcher & Common redpole \\
\hline Mew gull & Alder flycatcher & \\
\hline Anctic tern & Black-apped chickadee & \\
\hline Tree swallow & Boreal chickadee & \\
\hline Violet-green swallow & Anctic wabler & \\
\hline Cliff swallow & Ruby-crowned kinglet & \\
\hline Common raven & Swainson's thrush & \\
\hline Yellow wagtail & Varied thrush & \\
\hline Blackpoll warbler & Yellow-rumped warbler & \\
\hline Northern waterthrush & Savannah sparrow & \\
\hline Wilson's wathler & Whitecrowned sparrow & \\
\hline American tree sparrow & Darkeyed junco & \\
\hline Fox sparrow & Pine grosbeak & \\
\hline \multicolumn{3}{|l|}{ Snow bunting } \\
\hline Rusty blackbird & & \\
\hline
\end{tabular}

that used primarily riparian habitats in the interior nested later at increasing altitude (e.g., cliff swallow). Several species that nested both in the interior and on the coast apparently nested about the same dates in both locations (e.g., tree swallow, gray-cheeked thrush); however, others nested later on the coast than in interior valleys (e.g., common raven, orange-crowned warbler).

Variations among years in numbers of birds and breeding success were evident for several species on the Tuluksak River. Diving ducks and mergansers, some shorebirds, and swallows had variable combinations of reduced numbers, later breeding dates, and apparently reduced nesting success after the cold springs and the late-May and early-June snowstorms in 1962, 1978, and 1979. Conversely, breeding by resident and migrant passerines was exceptionally early in 1983 (c.g., American robin, pine grosbeak). Red fox predation on ducklings, especially goldeneye ducklings, was severe in 1983 following the snowshoe hare population crash of 1982. Similarly, the numbers and nesting success of the great horned owl, northern goshawk, and golden eagle were greatly altered by the snowshoe hare population peak of 1981 and crash in 1982.

The influence of human activity was evident for several species at the Tuluksak River (Table 20). Numbers of several species varied with the amount of garbage available for their use (e.g., common raven, rusty 
blackbird), and numbers of others varied with the amount of recent surface mining and resultant extent of tailings (c.g., semipalmated plover, wandering tattler, arctic tern) and vegetation at early states of succession (e.g., varied thrush, American tree sparrow). The general effect in the valley floor with the disturbance caused by mining activity was of increased density but reduced diversity of birds preferring woodlands or shrub habitats, and reduced density of birds more typically found in mature woodland communities.

Our data suggest high stability of raptor populations throughout the study area and higher stability of populations among woodland owls than open-country owls. Nesting and increased numbers of open-country owls (e.g., snowy owl) were associated with lemming cycles. Populations of predatory birds at the Tuluksak River tended to be stable because of the complex array of habitats (and its attendant community of prey) that resulted from 70 years of surface mining (Weir 1988).

Tens of thousands of king eiders, brant, Canada geese, and emperor geese use coastal estuaries and ice-free waters in the study area during migration in spring and fall. Nanvak, Goodnews, and Chagvan bays are obviously of extreme importance for waterfowl and shorebirds for resting and staging, both while waiting for nesting areas to become available in spring and early in fall migration (Table 3).

Eighteen species (10\% of 185$)$ were permanent residents (c.g., gyrfalcon, ruffed grouse, downy woodpecker) during some or all years, and 3 species (2\%) were winter residents (common eider, king eider, dark-eyed junco). All species that were considered permanent residents (e.g., golden eagle, boreal owl, gray jay) and one winter resident (darkeyed junco) occurred inland, and two species were winter residents only on the coast. The two coastal winter residents (common and king eiders) are dependent on open water; thus, when estuaries freeze and shore-fast ice forms, their winter distribution will be limited. More surveys and studies in winter on the Tuluksak River and areas not previously visited in winter may expand the list of permanent and winter residents.

Forty-five species (24\% of 185 ) were not thought to nest in the study area but probably pass through each year (e.g., snow goose, Steller's eider, Hudsonian godwit). Several species (e.g., black oystercatcher, Bohemian waxwing, white-winged crossbill) may occur in years when their populations are expanding, whereas others were out of their normal range (e.g., red knot, herring gull, Kittlitz's murrelet). Most very rare visitants (e.g., yellow-billed loon, Baikal teal, Terek sandpiper) were birds of northern latitudes; however, frigatebirds occur in more southern latitudes.

The Kilbuck and Ahklun mountains and their offshore islands had a variety of species nesting or possibly nesting that were at the limits of their normal ranges; had large numbers of some species during migration on the coast; and a diversity of rare-to-very-rare visitants on the coast. 
Possibly, the two species most exemplifying the phenomenon of a boundary or overlap between close congeners were dowitchers; the long-billed dowitcher nests primarily to the north and west, and the short-billed dowitcher nests primarily to the south, but both species probably nested on our study area near Goodnews Bay. Although further investigation is needed, the range of sympatric species or subspecies pairs nesting in our area is striking. Several of the species or species pairs that were sympatric in the area were Old World and New World forms; that is, a goshawk, possibly Siberian, bred with an American goshawk. The lesser (Pluvialis dominica) and Pacific golden-plovers ( $P$. fulva) are sympatric in western Alaska (Connors 1983); however, too few goldenplovers were collected in our area to document both species as nesting. Adult herring gulls on the west coast of our area were dark-mantled, whereas DNW saw light-mantled adults just north of our area at Aniak (village) in 1986, and just east of it at Dillingham in 1962. This suggested that Siberian Larus argentatus vegae occurred on the west coast, while American L.a. smithsonianus more or less reached the northern interior and southern coast.

Our study area is in the western Alaska biogeographic region of Kessel and Gibson (1978), but elements of the avifaunas of western Alaska, southwestern Alaska, southcoastal Alaska, and central Alaska are present. The taiga-tundra transitional nature of our avifauna, and the presence of both Beringian and Old World breeding forms fit Kessel and Gibson's (1978) concept of a western Alaska avifauna. However, the breeding waterfowl, seabirds, and shorebirds of our area include a number of species considered part of the southwestern, southcoastal, and southcoastal island avifaunas (c.f. Gabrielson and Lincoln 1959; Kessel and Gibson 1978). Many species and subspecies reach the southeastern and northwestern or western limit of their breeding or presumed breeding range in the study area.

We therefore conclude that the southern part of our area marks an avifaunal as well as physical limit between Bristol Bay and Kuskokwim Bay. We suggest that the western slope of the Kilbuck and Ahklun mountains is best regarded as part of the western Alaska biogeographic region and that the area from Cape Newenham east to the Togiak River is part of the southwestern Alaska biogeographic region. 


\section{Acknowledgments}

We thank C. J. Lensink for his constant encouragement to complete aspects of the study. We thank the following individuals for sharing of their observations of birds: P. D. Arneson, W. Arvey, C. Awe, J. Birch, J. Bloomquist, C. Clark, Jr., C. Clark, Sr., J. Durst, D. I. Eisenhauer, R. E. Gill, Jr., D. R. Herter (also with S. R. Johnson and S. Johnston), J. L. Hout, B. Huffmon, D. Lloyd, B. J. McCaffery, D. B. McDonald, D. Roseneau, and H. Svensen. The following individuals allowed us to cite their unpublished reports of observations of birds in the region (see Appendix): R. Baxter, D. A. Boyce, H. P. Brokaw, D. Campbell, C. P. Dau, T. J. Eley, Jr., M. J. Fry, R. E. Gill, Jr., L. Haggblom, D. R. Herter, B. M. Higgins, J. L. Hout, J. G. King, R. J. King, J. Klicka, R. MacIntosh, B. J. McCaffery, M. A. Monson, E. H. Miller, D. R. Money, D. L. O'Daniel, D. F. and J. M. Parmelee, L. van Hulsteyn, and K. Winker. Portions of the manuscript were reviewed by R. Stehn and R. E. Gill, Jr. R. C. Banks and B. Kessel reviewed the entire manuscript; we thank them for their helpful suggestions. We thank R. E. Gill, Jr., for providing the photograph for the frontispiece.

Many state and federal agencies, foundations, companies, and corporations supported this study between 1952 and 1988 . DNW gratefully acknowledges financial or logistic assistance from the U.S. Fish and Wildlife Service, U.S. Bureau of Land Management, Alaska Department of Fish and Game, Winston Churchill Memorial Foundation, New YorkAlaska Gold Dredging Corporation, Tuluksak Dredging Limited, Goodnews Bay Mining Company, Northland Mining Company, Red Salmon Cannery Company, and Westgold. Fieldwork by MHD was supported by the U.S. Fish and Wildlife Service and U.S. Bureau of Land Management, and MRP by the U.S. Fish and Wildlife Service. The U.S. Fish and Wildlife Service, Alaska Fish and Wildlife Research Center in Anchorage, Alaska, generously provided funds for preparation and publication of this paper. 


\section{References}

American Ornithologists' Union. 1983. Check-list of North American binds. Gth ed. American Omithologists' Union, Washington, D.C. 877 pp.

Arneson, P. D. 1977. Identification, documentation and delineation of coastal migratory bird habitat in Alaska. Pages 83-99 in Environmental assessment of the Alaskan Continental Shelf, quarterty reports of principal investigators, Vol. x. (National Oceanographic and Atmospheric Administration, Environ. Res. Lab., Boulder, Colo.)

Banks, R. C., R. W. McDiarmid, and A. L. Gardner, editors. 1987. Checklist of vertebrates of the United States, the U.S. Territories, and Canada. U.S. Fish Wildl. Serv., Resour. Publ. 166. 79 pp.

Bartonek, J. C., and D. D. Gibson. 1972. Summer distribution of pelagic birds in Bristol Bay, Alaska. Condor 74:416-422.

Bent, A. C. 1938. Life histories of North American birds of prey. Smithson. Inst., U.S. Natl. Mus. Bull. 170. 482 pp.

Brandt, H. 1943. Alaska bird trails. Bird Research Foundation, Cleveland, Ohio. 464 pp.

Brower, W. A. , Jr., R. G. Baldwin, C. N. Williams, Jr., J. L. Wise, and L. D. Leslie. 1988. Climatic atlas of the outer continental shelf waters and coastal regions of Alaska. Vol. 2. Bering Sea. Arctic Environmental Information and Data Center, University of Alaska, Anchorage.

Brown, L. M., and D. Amadon. 1968. Eagles, hawks and falcons of the world. Two vols. McGraw-Hill Book Company, New York.

Cady, W. M., R. E. Wallace, J. M. Hoare, and E. J. Webber. 1955. The central Kuskokwim region, Alaska. U.S. Geol. Surv. Prof. Pap. 268.

Chapman, F. M. 1904. List of birds collected in Alaska by the Andrew J. Stone expedition of 1903. Bull. Am. Mus. Nat. Hist. 20:399-406.

Connors, P. G. 1983. Taxonomy, distribution, and evolution of golden plovers (Pluvialis dominica and Pluvialis fulva). Auk 100:607-620.

Conover, H. B. 1926. Game birds of the Hopper Bay Region, Alaska. Auk 43:162-180, 303-318.

Dice, L. R. 1920a. The land vertebrate associations of interior Alaska. Univ. Mich. Occas. Pap. Mus. Zool. 85. 24 pp.

Dice, L. R. 1920b. Notes of some birds of interior Alaska. Condor 22:176-185.

Eley, T. J., Jr. 1976. Extension of the breeding range of the black oystercatcher in Alaska. Condor 78:115.

Erskine, A. J. 1977. Birds in boreal Canada: communities, densities and adaptations. Can. Wildl. Serv. Rep. Ser. 41.71 pp.

Friedmann, H. 1933. Notes on some birds of Goodnews Bay, Alaska. Condor 35:239-240.

Friedmann, H. 1934. The Mongolian plover and other birds at Goodnews Bay, Alaska. Condor 36:89.

Friedmann, H. 1936. Notes on Alaskan birds. Condor 38:173. 
Gabrielson, I. N., and F. C. Lincoln. 1959. The birds of Alaska. Stackpole Co., Harrisburg, Pennsylvania, and Wildlife Management Institute, Washington, D.C. 922 pp.

Gill, R. E., Jr., M. R. Petersen, and P. D. Jorgensen. 1981. Birds of the northcentral Alaska Peninsula. Arctic 34:286-306.

Handel, C. M., and R. E. Gill, Jr. 1992. Breeding distribution of the black turnstone. Wilson Bull. 104. In press.

Hartmann, C. W., and P. R. Johnson. 1977. Environmental atlas of Alaska. Institute of Water Research, University of Alaska, Fairbanks. 95 pp.

Herter, D. R., S. M. Johnson, and A. P. Woodman. 1989. Molt migration of scoters at Cape Peince, Alaska. Arctic 42:248-252.

Hoare, J. M., and W. L. Coonrad. 1959. Geology of the Bethel quadrangle, Alaska. U.S. Geol. Surv., Misc. Geologic Investigations, Map I-285.

Hoare, J. M., and W. L. Coonrad. 1961. Geologic map of the Hagemeister Island quadrangle, Alaska. U.S. Geol. Surv., Misc. Geologic Investigations, Map I-321.

Hultén, E. 1968. Flora of Alaska and neighboring territories. Stanford University Press, Stanford, Calif. 1008 pp.

Hurley, J. B. 1931-32. Birds observed in the Bristol Bay region, Alaska. Murrelet $12: 7-11,34-43,71-75 ; 13: 16-21,38-40$.

Johnson, S. R., editor. 1985. Population estimates, productivity and food habits of nesting seabirds at Cape Peirce and the Pribilof Islands, Bering Sea, Alaska. U.S. Dep. Int., Minerals Manage. Serv. MMS 85-0068.

Kessel, B. 1979. Avian habitat classification for Alaska. Murrelet 60:86-94.

Kessel, B. 1989. Birds of the Seward Peninsula, Alaska. University of Alaska Press. 330 pp.

Kessel, B., and D. D. Gibson. 1978. Status and distribution of Alaska birds. Stud. Avian Biol. 1. 100 pp.

King, J. G., and C. P. Dau. 1981. Waterfowl and their habitats in the eastern Bering Sea. Pages 739-753 in D. W. Hood and J. A. Calder, eds. Eastern Bering Sea shelf: oceanography and resources. Vol. 2. U.S. Department of Commerce, National Oceanic and Atmospheric Administration, Washington, D.C.

Lloyd, D. S. 1985. Breeding performance of kittiwakes and murres in relation to oceanographic and meteorologic conditions across the shelf of the southeastem Bering Sea. M. S. thesis, University of Alaska, Fairbanks.

Mindell, D. P. 1983. Nesting raptors in southwestem Alaska: status, distribution, and aspects of biology. U.S. Bur. Land Manage., Tech. Rep. BLM/AK/TR-83/08. 59 pp.

Newton, I. 1972. Finches. New Nat. Ser., Collins, London. 288 pp.

Osgood, W. H. 1904. A biological reconnaissance of the base of the Alaska Peninsula. N. Am. Fauna 24. 86 pp.

Parmelee, D. F., and J. M. Parmelee. 1988. Ravens observed killing roosting kittiwakes. Condor 90:952.

Petersen, M. R. 1982. Predation on seabirds by red foxes at Shaiak Island, Alaska. Can. Field-Nat. 96:41-45.

Pitelka, F. A. 1950. Geographic variation and the species problem in the shore-bird genus Limnodromus. Univ. Calif. Publ. Zool. 50:1-108.

Salter, R. E., M. A. Gollop, S. R. Johnson, W. R. Koski, and C. E. Tull. 1980. Distribution and abundance of birds on the Arctic coastal plain of northern 
Yukon and adjacent Northwest Territories, 1971-1976. Can. Field-Nat. 94:219-238.

Selkregg, L. L. 1976. Alaska regional profles. Office of the Governor, Alaska and Joint Federal-State Land Use Planning Commission for Alaska. Vol. III. University of Alaska, Arctic Environmental Information and Data Center, Anchorage. $313 \mathrm{pp}$.

Sharrock, J. T. R. 1976. The atlas of breeding birds in Britain and Ireland. British Trust for Ornithology and Irish Wildbird Conservancy, Poyser, Hertfordshire, England. 479 pp.

Sowls, A. L., S. A. Hatch, and C. J. Lensink. 1978. Catalog of Alaskan seabind colonies. U.S. Fish Wildl. Serv., FWS/ORS-78/78. 351 pp.

Spindler, M. A., and B. Kessel. 1980. Avlan populations and habitat use in interior Alaska taiga. Syesis 13:61-104.

Viereck, L. A., and E. L. Little, Jr. 1972. Alaska trees and shrubs. U.S. For. Serv., Agric. Handb. 410. 265 pp.

Walkinshaw, L. H. 1948a. Nesting of some shorebirds in westem Alaska. Condor 50:220-223.

Walkinshaw, L. H. 1948b. Nesting of some passerine birds in western Alaska. Condor 50:64-70.

Walkinshaw, L. H. 1949. Some whistling swan observations in western Alaska. Wilson Bull. 61:111.

Walkinshaw, L. H., and J. J. Stophlet. 1949. Bird observations at Johnson River, Alaska. Condor 51:29-34.

Watson, G. E., and G. J. Divoky. 1972. Pelagic bird and mammal observations in the eastem Chukchi Sea, early fall 1970. Pages 111-172 in An ecological survey in the eastern Chukchi Sea, September-October 1970. U.S. Coast Guard Oceanographic Report 50.

Weir, D. N. 1982. Cliff nesting raptors of the Kisaralik River, western Alaska. Pages 138-152 in W. N. Ladd and P. F. Schempf, eds. Proceedings of a symposium and workshop on raptor management and biology in Alaska and westem Canada. U.S. Fish Wildl. Serv., FWS/AK/PROC-82. 335 pp.

Weir, D. N. 1988. Impact of prolonged surface mining on numbers of Alaska predators. In B. Clark, ed. Proceedings of an advanced policy workshop on environmental management and impact assessment. Centre for Environmental Management and Planning, Aberdeen University, Aberdeen, Scotland.

Weir, D. N., and A. Hanson. 1989. Food habits of great homed owls, Bubo virginianus, in the northem taiga of the Yukon Territory and Alaska. Can. Field-Nat. 103:12-17.

White, C. M., and D. A. Boyce, Jr. 1978. A profile of various rivers and their raptor populations in westem Alaska, 1977. U.S. Bur. Land Manage., Tech. Rep. BLM/AK/TR/78/01. 77 pp.

Williamson, F. S. L. 1957. Ecological distribution of birds in the Napaskiak area of the Kuskokwim River Delta, Alaska. Condor 59:317-338.

Williamson, F. S. L., and L. J. Peyton. 1962. Faunal relationships of birds in the Iliamna Lake area, Alaska. Univ. of Alaska Biol. Pap. 5. 72 pp.

Woodman, P., S. Johnston, C. Richards, T. Pogson, and D. Herter. 1985. Molt migration of scoters at Cape Peirce, Alaska. Page 13 in T. C. Rothe, ed. Alaska bird conference. Alaska Dep. Fish Game, Anchorage. (Abstr.) 


\section{Appendix. Unpublished Reports on Birds in the Study Region}

Baxter, R. 1976. Bird check lists, Eek River, tributary to Kuskokwim River, 5-10 August 1976. Unpublished report. Alaska Department of Fish Game, Bethel. 4 pp.

Brown, M., N. Brown, M. Ada, K. Bolovan, M. Lapin, K. Sullivan, and C. Ziobron. 1985. Yukon Delta National Wildlife Refuge general biological inventory, Kisaralik River-1985. Unpublished report. U.S. Fish Wildl. Serv., Bethel, Alaska. 40 pp.

Brown, M., P. Paniyak, and M. Lapin. 1985. Yukon Delta National Wildlife Refuge general biological inventory, Eek River-1985. Unpublished report. U.S. Fish Wildl. Serv., Bethel, Alaska. 52 pp.

Brown, M., P. Paniyak, and M. Lapin. 1985. Yukon Delta National Wildlife Refuge general biological inventory, Kwethluk River-1985. Unpublished report. U.S. Fish Wildl. Serv., Bethel, Alaska. 44 pp.

Boyce, D. A., and S. J. Fristensky. 1984. A profile of raptors and other fauna of the Kisaralik River, July 1984. Unpublished report. U.S. Fish Wildl. Serv., Anchorage, Alaska. 27 pp.

Brokaw, H. P. 1970. Birds of the Cape Peirce area June 1970. Unpublished report. U.S. Fish Wildl. Serv., Bethel, Alaska. 7 pp.

Campbell, D., and P. Greci. 1986. Waterfowl staging and migration in Nanvak Bay; fall 1986. Unpublished report. U.S. Fish Wildl. Serv., Dillingham, Alaska. 18 pp.

Dau, C. P. 1981. Spring survey of emperor geese, southwestem Alaska, 23 to 27 April 1981. Unpublished trip report. U.S. Fish Wildl. Serv., Cold Bay, Alaska. $16 \mathrm{pp}$.

Dau, C. P. 1981. Surveys of migratory bird staging, molting and migration areas, April-October 1981. Unpublished report. U.S. Fish Wildl. Serv., Anchorage, Alaska. 17 pp.

Dau, C. P. 1982. Spring survey of emperor geese in southwestern Alaska, 3-4 May 1982. Unpublished report. U.S. Fish Wildl. Serv., Cold Bay, Alaska. 20 pp.

Dau, C. P. 1983. Spring survey of emperor geese in southwestern Alaska, 25-28 April 1983. Unpublished report. U.S. Fish Wildl. Serv., Cold Bay, Alaska. $21 \mathrm{pp}$.

Dau, C. P. 1984. Spring survey of emperor geese in southwestern Alaska, 28-30 April, 4 May. Unpublished report. U.S. Fish Wildl. Serv., Cold Bay, Alaska. 31 pp.

Dau, C. P., and R. J. King. 1985. Spring survey of emperor geese in southwestern Alaska, 12-16 May 1985. Unpublished report. U.S. Fish Wildl. Serv., Cold Bay, Alaska. 26 pp. 
Dau, C. P., and R. J. King. 1986. Spring survey of emperor geese in southwestern Alaska, 4-7 May 1986. Unpublished report. U.S. Fish Wildl. Serv., Cold Bay, Alaska. 25 pp.

Eley, T. J., Jr. 1974. The birds of Round Island, Alaska. Unpublished report. Johns Hopkins University, Baltimore, Maryland. 12 pp.

Fry, M. J. 1962. Birds at Kagati Lake and Kanektok River, July-August 1962. Unpublished report to D. N. Weir.

Gill, R. E., Jr. 1981. Fall survey of emperor geese from Hooper Bay to Unimak Island and along the south Alaska Peninsula from Unimak Island to Wide Bay-3-8 October 1981. Unpublished report. U.S. Fish Wildl. Serv., Anchorage, Alaska. 7 pp.

Gill, R. E., Jr., and B. Conant. 1979. Aerial water bird survey-Bethel to Bechevin Bay, Alaska (1-4 October 1979). Unpublished report. U.S. Fish Wildl. Serv., Anchorage, Alaska. $11 \mathrm{pp}$.

Gill, R. E., Jr., and R. King. 1980. Aerial water bird survey-Bethel to Bechevin Bay, Alaska (4-8 October 1980). Unpublished report. U.S. Fish Wildl. Serv., Anchorage, Alaska. $11 \mathrm{pp}$.

Haggblom, L. 1989. Population and productivity of black-legged kittiwakes, common murres, and pelagic cormorants at Cape Peirce, Bristol Bay, Alaskasummer 1989. Unpublished report. U.S. Fish Wildl. Serv., Dillingham, Alaska. $60 \mathrm{pp}$.

Haggblom, L., and A. O'Ncil. 1987. Population and productivity surveys of black-legged kittiwakes, common murres, and pelagic cormorants at Cape Peirce, Alaska, summer 1987. Unpublished report. U.S. Fish Wildl. Serv., Dillingham, Alaska. 20 pp.

Herter, D. R., and B. Higgins. 1986. Seabird observations at Cape Peirce, summer 1985. Unpublished report. U.S. Fish Wildl. Serv., Dillingham, Alaska. 7 pp.

Higgins, B. M. 1985. Seabird abundance and behavior on Cape Peirce, Alaska-1985. Unpublished report. U.S. Fish Wildl. Serv., Anchorage, Alaska. 5 pp.

Hout, J. L. 1970. Cape Newenham National Wildlife Range, 1969 Annual Report. Unpublished report. U.S. Fish Wildl. Scrv., Bethel, Alaska. 13 pp.

Hout, J. L. 1972. Cape Newenham National Wildlife Range, 1971 Annual Report. Unpublished report. U.S. Fish Wildl. Serv., Bethel, Alaska. 7 pp.

King, J. G. 1966. Cape Newenham, Alaska: a wildlife metropolis. U.S. Fish Wildl. Serv. Juneau, Alaska. 34 pp. Unpublished report.

King, J. G., and M. A. Monson. 1968. Report of field inspection trip of bird resources of Bristol Bay, 22-23 April 1968. Unpublished report. U.S. Fish Wildl. Serv., Juncau, Alaska.

King, R. J., and K. S. Bollinger. 1982. Fall survey of emperor geese and other associated water birds of coastal southwest Alaska-6-10 October 1982. Unpublished report. U.S. Fish Wildl. Serv., Fairbanks, Alaska. 7 pp.

King, R. J., and C. P. Dau. 1987. Spring survey of emperor geese in southwestern Alaska, 30 April-4 May 1987. Unpublished report. U.S. Fish Wildl. Serv., Fairbanks, Alaska. 13 pp.

King, R. J., and C. P. Dau. 1989. Aerial spring survey of emperor geese (Chen canagica) in southwestern Alaska, 3-6 May 1989. Unpublished report. U.S. Fish Wildl. Serv., Fairbanks, Alaska. 17 pp. 
King, R. J., and L. Denlinger. 1989. Fall population survey of emperor geese (Chen canagica) in coastal southwest Alaska, 7-12 October 1989. Unpublished report. U.S. Fish Wildl. Serv., Fairbanks, Alaska. 17 pp.

King, R. J., and W. D. Eldridge. 1985. Fall survey of emperor geese (Chen canagica)-southwest coastal Alaska, 10-14 October 1985. Unpublished report. U.S. Fish Wildl. Serv., Fairbanks, Alaska. 8 pp.

King, R. J., and W. D. Eldridge. 1987. Fall population survey of emperor geese (Chen canagica)-southwest coastal Alaska. Unpublished report. U.S. Fish Wildl. Serv., Fairbanks, Alaska. 8 pp.

MacIntosh, R. 1976. Observations of birds on and around Round Island, Alaska on 27 June 1976. Unpublished report.

McCaffery, B. J., and R. D. Ernst. 1989. Cliff-nesting raptors of the Kisaralik River: 1977-1988. Unpublished report. U.S. Fish Wildl. Serv., Bethel, Alaska. 27 pp.

Miller, E. H. 1973. Report on activities on Round Island (Walrus Islands), Bristol Bay, Alaska, 5 June-12 July 1972. Unpublished report. Alaska Cooperative Wildlife Research Unit, University of Alaska, Fairbanks. 11 pp.

Money, D. L. 1976. Observed wildlife values along the Kisaralik River for 7 August through 14 August 1976. Unpublished report. Bureau of Land Management, Anchorage, Alaska. 3 pp.

O'Daniel, D. L. 1988. Population and productivity studies of black-legged kittiwakes, common murres, and pelagic cormorants at Cape Peirce, Alaska, summer 1988. Unpublished report. U.S. Fish Wildl. Serv., Dillingham, Alaska. 26 pp.

Parmelee, D. F., and J. M. Parmelec. 1987. Annotated list of the birds of Chagvan Bay, Alaska. Unpublished report. U.S. Fish Wildl. Serv., Dillingham, Alaska. 21 pp.

Van Hulsteyn, L., and K. Kavanaugh. 1987. Population and productivity surveys of black-legged kittiwakes, common murres, and pelagic cormorants at Cape Peirce, Alaska, summer 1986. Unpublished report. U.S. Fish Wildl. Serv., Dillingham, Alaska. 19 pp.

Winker, K., and J. Klicka. 1990. Some avian notes from northwestern Bristol Bay, Alaska. Unpublished manuscript. Bell Museum of Natural History, Minneapolis, Minnesota. 2 pp. 